\title{
ॠUSGS
}

science for a changing world

Prepared in cooperation with the

OFFICE OF ENVIRONMENTAL RESTORATION AND

WASTE MANAGEMENT,

U.S. DEPARTMENT OF ENERGY

NATIONAL NUCLEAR SECURITY ADM INISTRATION,

NEVADA OPERATIONS OFFICE, under

Interagency Agreement DE-AI08-96NV11967

\section{A Three-Dimensional Numerical Model of Predevelopment Conditions in the Death Valley Regional Ground-Water Flow System, Nevada and California}

Water-Resources Investigations Report 02-4102

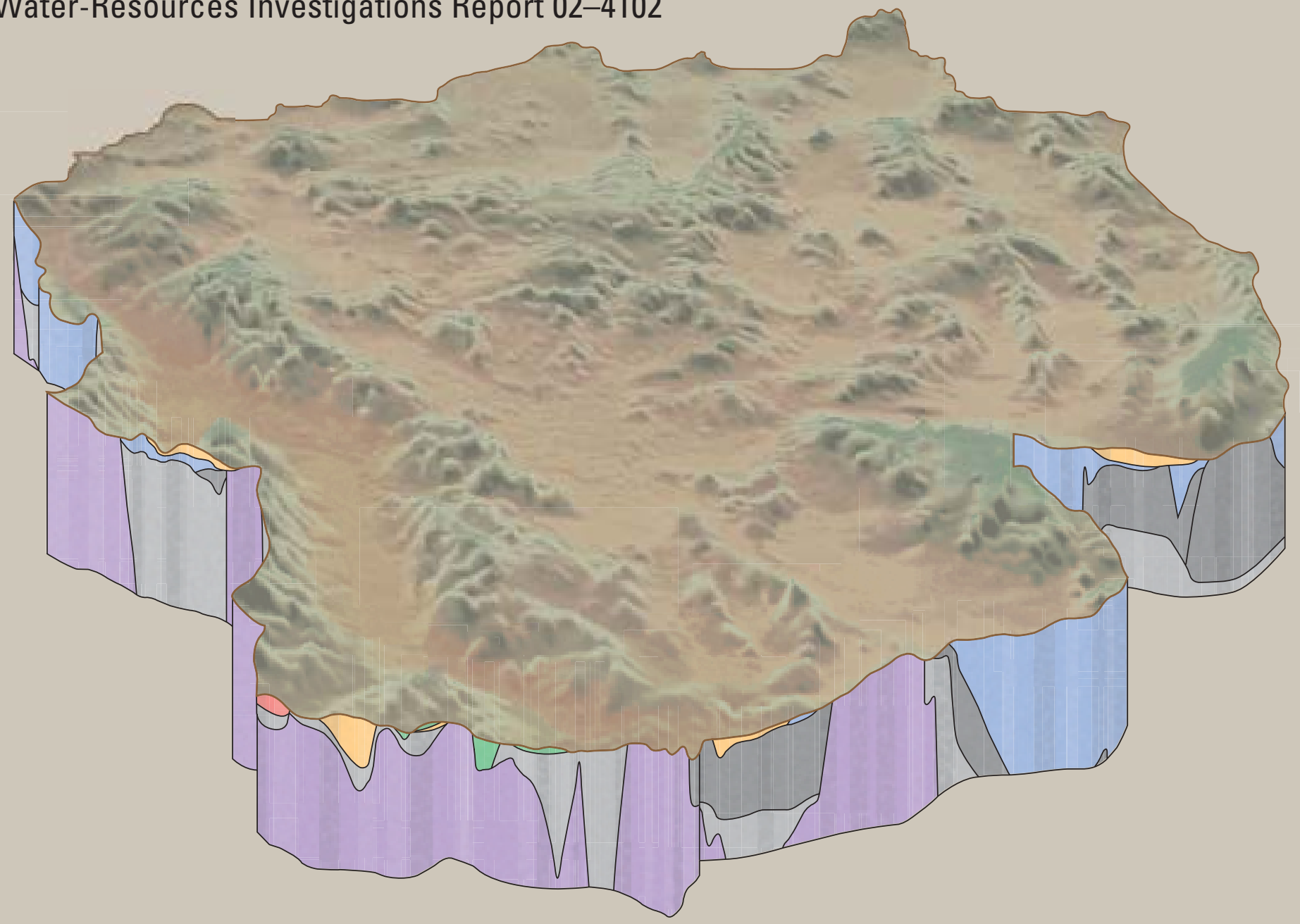

U.S. DEPARTMENT OF THE INTERIOR

U.S. GEOLOGICAL SURVEY 


\section{A Three-Dimensional Numerical Model of Predevelopment Conditions in the Death Valley Regional Ground-Water Flow System, Nevada and California}

By Frank A. D'Agnese, Grady M. O'Brien, Claudia C. Faunt, Wayne R. Belcher, and Carma San Juan

U.S. GEOLOGICAL SURVEY

Water-Resources Investigations Report 02-4102

Prepared in cooperation with the OFFICE OF ENVIRONMENTAL RESTORATION AND WASTE MANAGEMENT, U.S. DEPARTMENT OF ENERGY, NATIONAL NUCLEAR SECURITY ADMINISTRATION, NEVADA OPERATIONS OFFICE, under Interagency Agreement DE-AI08-96NV11967 


\title{
U.S. DEPARTMENT OF THE INTERIOR GALE A. NORTON, Secretary
}

\author{
U.S. GEOLOGICAL SURVEY
}

Charles G. Groat, Director

The use of firm, trade, and brand names in this report is for identification purposes only and does not constitute endorsement by the U.S. Geological Survey.

For additional information write to:

Chief, Yucca Mountain Project Branch

U.S. Geological Survey

Box 25046, Mail Stop 421

Denver Federal Center

Denver, CO 80225-0046
Copies of this report can be purchased from:

U.S. Geological Survey Information Services Box 25286 Denver Federal Center Denver, CO 80225 


\section{CONTENTS}

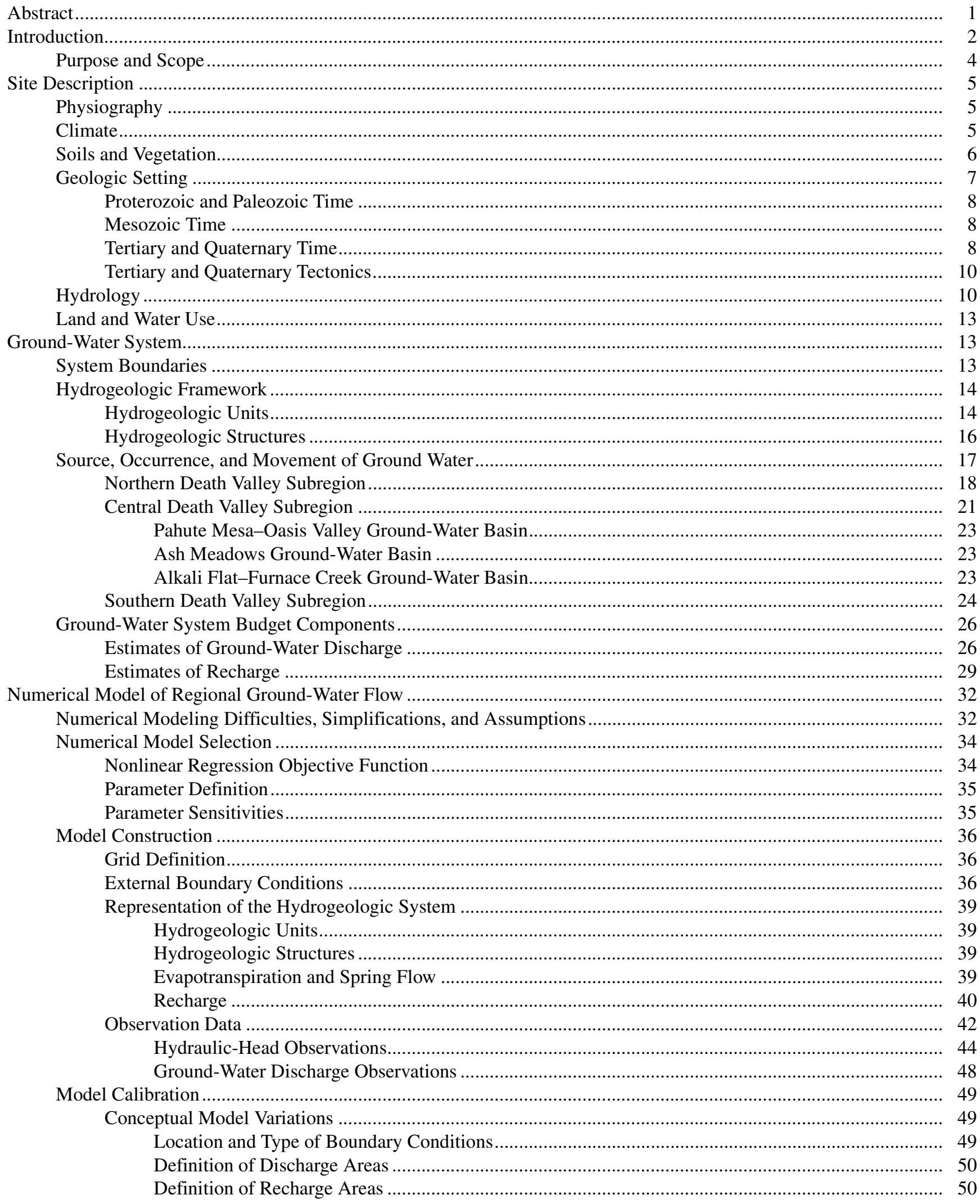




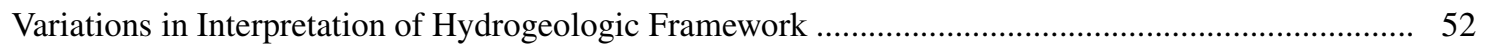

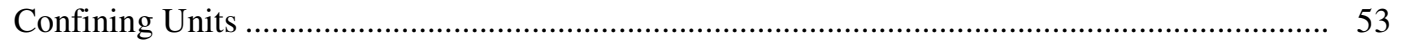

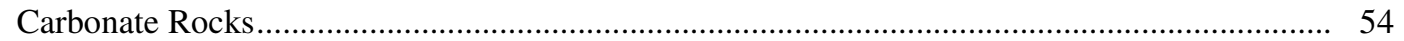

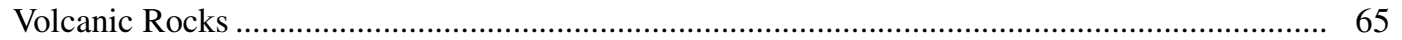

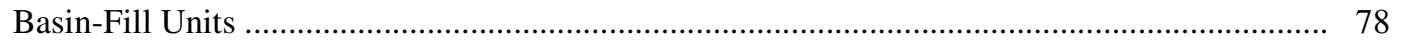

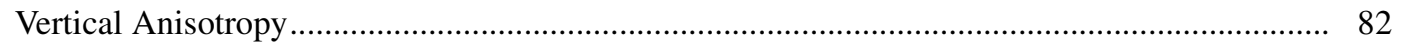

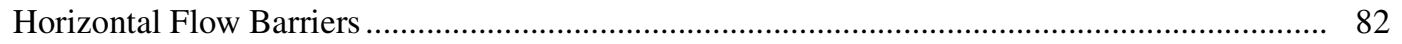

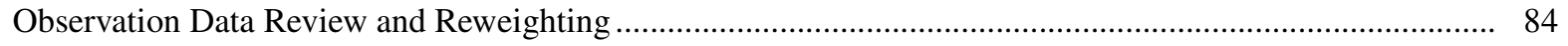

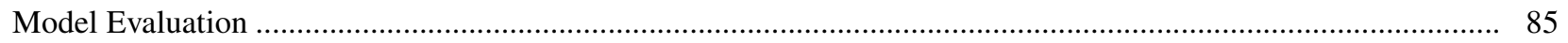

Evaluation of Simulated Hydraulic Head and Ground-Water Discharge .................................................... 85

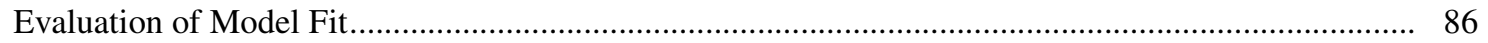

Spatial Distribution of Unweighted and Weighted Residuals ........................................................... 86

Distribution of Weighted Residuals Relative to Weighted Simulated Values ..................................... 90

Normality of Weighted Residuals and Model Linearity ........................................................................ 90

Evaluation of Estimated Parameter Values and Sensitivities..................................................................... 95

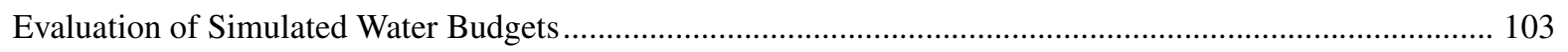

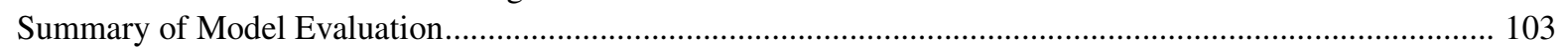

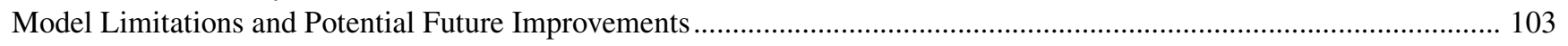

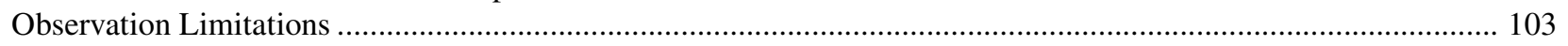

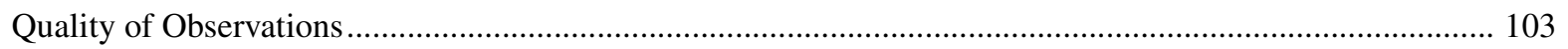

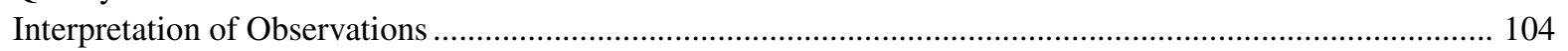

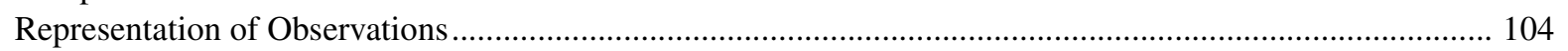

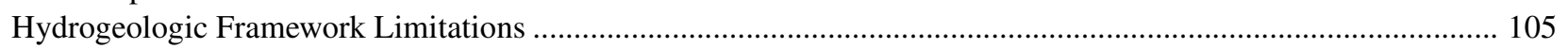

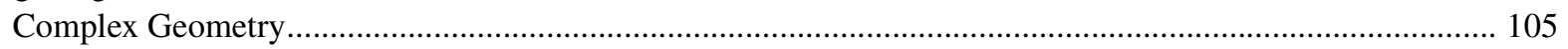

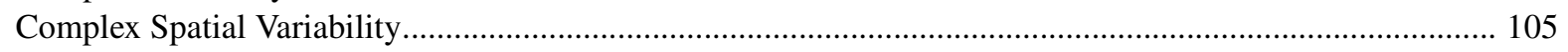

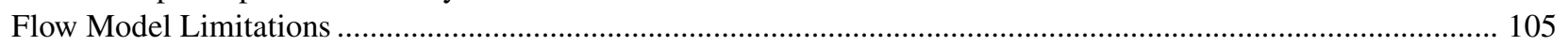

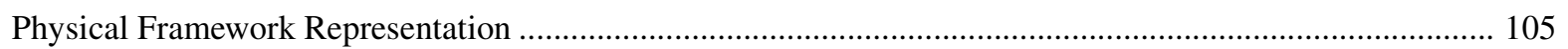

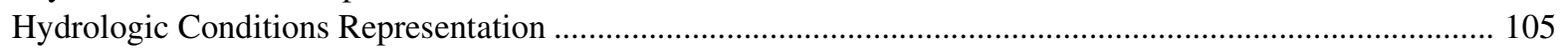

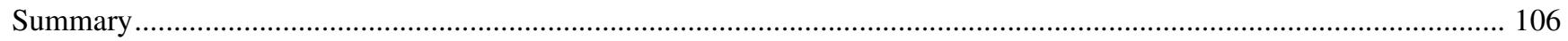

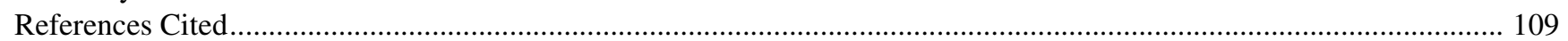

\section{FIGURES}

1-19. Maps showing:

1. Graphic and prominent topographic features of the Death Valley region, Nevada and California.................. 3

2. Desert climatic zones of the Death Valley region ............................................................................. 6

3. Weather regimes of the Death Valley region.................................................................................. 7

4. Tectonic features of the Death Valley region and vicinity .................................................................... 9

5. Structural-physiographic subsections of the Death Valley region .............................................................. 11

6. Hydrographic areas of the Death Valley region .................................................................................... 12

7. Interpreted subregions, ground-water basins, and associated flow paths of the Death Valley regional

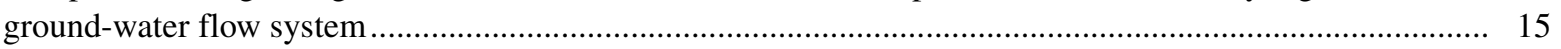

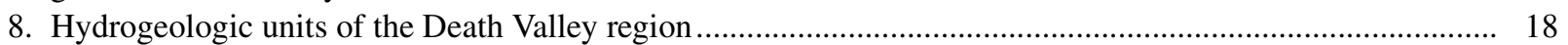

9. Hydrogeologic features interpreted as potential flow barriers ............................................................ 19

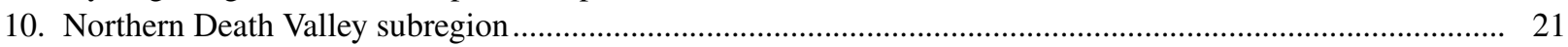

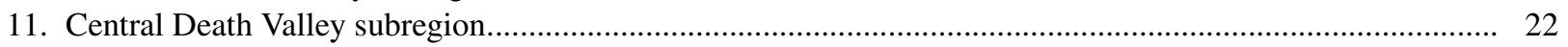

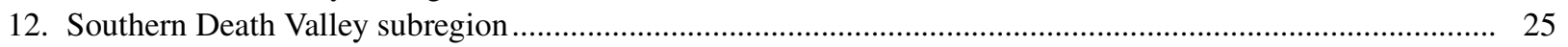

13. Ground-water discharge areas in the Death Valley regional flow system.................................................. 28

14. Net infiltration for the Death Valley regional flow system using INFIL ................................................. 33

15. Location of Death Valley regional flow system model grid...................................................................... 37

16. Death Valley regional flow system model boundary conditions and constant-head cells.............................. 38

17. Delineation of evapotranspiration units and zones in the Oasis Valley discharge area, Nevada..................... 41

18. Model cells representing drains used to simulate ground-water discharge from the Death Valley regional

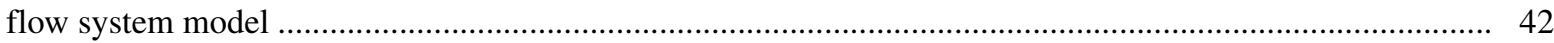


19. Recharge zone multiplication array representing hydrogeologic units at the water table

20. Graph showing distribution of standard deviation values assigned to hydraulic-head observations to determine weights from the premodeling observation analysis and the calibrated model....

21-41. Maps showing:

21. Recharge simulated in the Death Valley regional flow system model

22. Definition of lower clastic confining unit hydraulic-conductivity zone parameters and unit thickness..........

23. Definition of Precambrian granites and metamorphic rocks hydraulic-conductivity zone parameters and unit thickness.

24. Definition of Tertiary-Jurassic intrusives hydraulic-conductivity zone parameters and unit thickness

25. Definition of hydraulic-conductivity parameters and unit thickness for Mesozoic volcaniclastic and sedimentary rocks, upper clastic confining unit, and lower clastic confining unit thrust-fault units

26. Definition of hydraulic-conductivity parameters and unit thickness for upper carbonate aquifer and lower carbonate aquifer thrust-fault units

27. Definition of lower carbonate aquifer hydraulic-conductivity zone parameters and unit thickness.

28. Definition of Belted Range aquifer hydraulic-conductivity zone parameters and unit thickness

29. Definition of Timber Mountain/Pahute Mesa basal confining unit hydraulic-conductivity zone parameters and unit thickness

30. Definition of Timber Mountain/Pahute Mesa basal aquifer hydraulic-conductivity zone parameters and unit thickness

31. Definition of Bullfrog confining unit hydraulic-conductivity zone parameters and unit thickness.

32. Definition of Paintbrush/Calico Hills tuff cone hydraulic-conductivity zone parameters and unit thickness

33. Definition of Timber Mountain aquifer hydraulic-conductivity zone parameters and unit thickness ............. 73

34. Definition of volcanic aquifer hydraulic-conductivity zone parameters and unit thickness......................... 74

35. Definition of volcanic confining unit hydraulic-conductivity zone parameters and unit thickness ................ 75

36. Definition of undifferentiated volcanic rocks hydraulic-conductivity zone parameters and unit thickness..... 76

37. Definition of Quaternary-Tertiary playa deposits hydraulic-conductivity zone parameters and unit thickness 79

38. Definition of Tertiary sediments/Death Valley section hydraulic-conductivity zone parameters and unit thickness.....

39. Definition of Quaternary-Tertiary valley-fill alluvium hydraulic-conductivity zone parameters and unit thickness

40. Hydraulic-head residuals (observed minus simulated) and simulated potentiometric surface for model layer 1

41. Hydraulic-head weighted residuals (observed minus simulated) and simulated potentiometric surface for model layer 1

42-55. Graphs showing:

42. Ground-water discharge residuals with expected observed discharge variation.........

43. Simulated and observed ground-water discharge for major discharge areas.

44. Observed and simulated ground-water discharge

45. Ground-water discharge weighted residuals

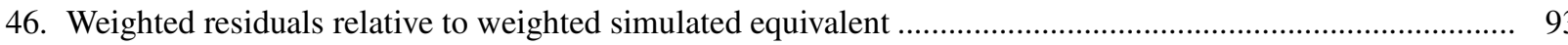

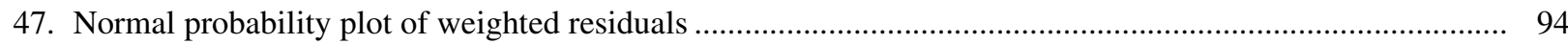

48. Normal probability plot of weighted residual against correlated normal number ..................................... 94

49. Parameters defining hydraulic conductivity for Precambrian granites and metamorphic rocks and Tertiary-Jurassic intrusives; $A$, Composite scaled sensitivity; $B$, Hydraulic conductivity assigned for each parameter and expected parameter-value range.....

50. Parameters defining hydraulic conductivity for the upper clastic confining unit and lower clastic confining unit, hydrogeologic units greater than 300 meters below land surface; $A$, Composite scaled sensitivity; $B$, Hydraulic conductivity assigned or estimated for each parameter and linear 95-percent confidence interval for estimated parameters 
51. Parameters defining hydraulic conductivity for the upper clastic confining unit and lower clastic confining unit, hydrogeologic units less than 300 meters below land surface; $A$, Composite scaled sensitivity; $B$, Hydraulic conductivity assigned for each parameter, and linear 95 -percent confidence interval for estimated parameter.

52. Parameters defining hydraulic conductivity for the lower carbonate aquifer and the upper carbonate aquifer; $A$, Composite scaled sensitivity; $B$, Hydraulic conductivity assigned or estimated for each parameter, expected parameter-value range, and linear 95-percent confidence interval for estimated parameters

53. Parameters defining hydraulic conductivity for undifferentiated volcanics, volcanic aquifer, volcanic confining unit, and Timber Mountain/Pahute Mesa volcanic rocks; $A$, Composite scaled sensitivity; $B$, Hydraulic conductivity assigned or estimated for each parameter, expected parameter-value range, and linear 95-percent confidence interval for estimated parameters.

54. Parameters defining hydraulic conductivity for basin fill: Quaternary-Tertiary valley-fill alluvium, Quaternary-Tertiary playa deposits, and Tertiary sediments/Death Valley section; $A$, Composite scaled sensitivity; $B$, Hydraulic conductivity assigned or estimated for each parameter, expected parameter-value range, and linear 95-percent confidence interval for esimated parameters.

55. Parameters defining hydraulic conductivity for lower clastic confining unit thrusts, Mesozoic volcaniclastic and sedimentary rocks, and lower carbonate aquifer thrusts; $A$, Composite scaled sensitivity; $B$, Hydraulic conductivity assigned for each parameter and expected parameter-value range

\section{TABLES}

1. Hydrogeologic units used in the Death Valley regional flow system model and in previous U.S. Department of Energy models in the Death Valley region.

2. Divisions of the Death Valley regional ground-water flow system......

3. Description of flow observations with observed discharge and coefficient of variation used in the calibrated model.

4. Area-altitude classes modified from Maxey and Eakin (1950)

5. Thickness and depth to top of each model layer

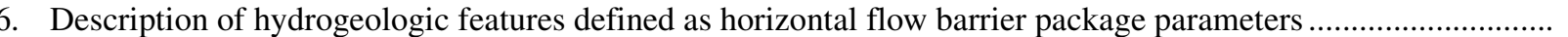

7. Description of recharge parameters defined for the recharge zones shown in figure 19 ....................................

8. Possible "UseFlag" entries used to attribute water-level measurements in the Death Valley regional flow system database.

9. Possible "ConditionFlag" entries used to attribute water-level measurements in the Death Valley regional flow system database

10. Possible "MethodFlag" entries used to attribute water-level measurements in the Death Valley regional flow system database

11. Accuracy assigned to water-level measurements based on method of measurement .

12. Drain parameter values and composite scaled sensitivities

13. Recharge parameter descriptions, values, and composite scaled sensitivities

14. Hierarchical structure of hydrogeologic unit parameters and major events guiding parameter delineation........... 59

15. Description of lower clastic confining unit (LCCU) horizontal hydraulic-conductivity parameters...................... 61

16. Description of Precambrian granites and metamorphic rocks ( $\mathrm{pCgm})$ horizontal hydraulic-conductivity parameters

17. Description of Tertiary-Jurassic intrusives (TJi) horizontal hydraulic-conductivity parameters ........................ 62

18. Description of lower carbonate aquifer (LCA) horizontal hydraulic-conductivity parameters ............................ 66

19. Description of Paintbrush/Calico Hills tuff cone (TC) horizontal hydraulic-conductivity parameters ................. 77

20. Description of Timber Mountain/Pahute Mesa basal confining unit (TBCU) horizontal hydraulic-conductivity parameters

21. Description of Timber Mountain/Pahute Mesa basal aquifer (TBQ) horizontal hydraulic-conductivity parameters 77

22. Description of volcanic aquifer (VA) horizontal hydraulic-conductivity parameters ......................................... 77

23. Description of volcanic confining unit (VCU) horizontal hydraulic-conductivity parameters............................. 77

24. Description of undifferentiated volcanic rocks (VU) horizontal hydraulic-conductivity parameters.................... 78

25. Description of Quaternary-Tertiary valley-fill alluvium (QTal) horizontal hydraulic-conductivity parameters .... 82 
26. Description of Quaternary-Tertiary playa deposits (QTp) horizontal hydraulic-conductivity parameters

27. Description of Tertiary sediments/Death Valley section (TSDVS) horizontal hydraulic-conductivity parameters 83

28. Vertical anisotropy parameter descriptions, values, and composite scaled sensitivities................................... 84

29. Horizontal flow barrier parameter values and composite scaled sensitivities .................................................. 85

30. Water budget for the simulated values in the calibrated model compared with estimates from this study ........... 87

\section{CONVERSION FACTORS AND VERTICAL DATUM}

\begin{tabular}{rll}
\hline \multicolumn{1}{c}{ Multiply } & By & To Obtain \\
\hline millimeter $(\mathrm{mm})$ & 0.03937 & inch \\
meter $(\mathrm{m})$ & 3.281 & foot \\
kilometer $(\mathrm{km})$ & 0.6214 & mile \\
& Area & acre \\
square hectometer $\left(\mathrm{hm}^{2}\right)$ & 2.471 & square mile \\
square kilometer $\left(\mathrm{km}^{2}\right)$ & 0.3861 & \\
& Volumetric Rate & acre-foot per year \\
cubic meter per day $\left(\mathrm{m}^{3} / \mathrm{d}\right)$ & 0.2961 & cubic foot per second \\
cubic meter per day $\left(\mathrm{m}^{3} / \mathrm{d}\right)$ & 0.0004087 & gallon per minute (gpm)
\end{tabular}

Temperature: Degrees Celsius $\left({ }^{\circ} \mathrm{C}\right)$ can be converted to degrees Fahrenheit $\left({ }^{\circ} \mathrm{F}\right)$ by the formula ${ }^{\circ} \mathrm{F}=\left(1.8 \times{ }^{\circ} \mathrm{C}\right)+32$.

Sea level: In this report "sea level" refers to the National Geodetic Vertical Datum of 1929_a geodetic datum derived from a general adjustment of the first-order level nets of the United States and Canada, formerly called Sea Level Datum of 1929.

\section{Symbol Definitions AND ACronymS}

$\begin{array}{ll}\text { 3D } & \text { Three dimensional } \\ \text { CSS } & \text { Composite scaled sensitivity } \\ \text { CV } & \text { Coefficient of variation } \\ \text { DEM } & \text { Digital elevation model } \\ \text { DRN } & \text { Drain } \\ \text { DVRFS } & \text { Death Valley regional flow system (model domain) } \\ \text { ET } & \text { Evapotranspiration } \\ \text { GIS } & \text { Geographic information system } \\ \text { HFB } & \text { Horizontal flow barrier } \\ \text { HFM } & \text { Hydrogeologic framework model } \\ \text { HUF } & \text { Hydrogeologic-unit flow } \\ \text { INFIL } & \text { Net infiltration model } \\ \text { LCA } & \text { Lower carbonate aquifer } \\ \text { LCCU } & \text { Lower clastic confining unit } \\ \text { LVVSZ } & \text { Las Vegas Valley shear zone } \\ \text { Mvs } & \text { Mesozoic volcaniclastic and sedimentary rocks } \\ \text { NTS } & \text { Nevada Test Site } \\ \text { NWIS } & \text { National Water Information System } \\ \text { pCgm } & \text { Precambrian granites and metamorphic rocks } \\ \text { QTal } & \text { Quaternary-Tertiary valley-fill alluvium }\end{array}$




$\begin{array}{ll}\text { QTp } & \text { Quaternary-Tertiary playa deposits } \\ \text { SWNVF } & \text { Southwest Nevada Volcanic Field } \\ \text { TBA } & \text { Belted Range aquifer } \\ \text { TBCU } & \text { Timber Mountain/Pahute Mesa basal confining unit } \\ \text { TBQ } & \text { Timber Mountain/Pahute Mesa basal aquifer } \\ \text { TC } & \text { Paintbrush/Calico Hills tuff cone } \\ \text { TCB } & \text { Bullfrog confining unit } \\ \text { TJi } & \text { Tertiary-Jurassic intrusives } \\ \text { TMA } & \text { Timber Mountain aquifer } \\ \text { TSDVS } & \text { Tertiary sediments/Death Valley section } \\ \text { UCA } & \text { Upper carbonate aquifer } \\ \text { UCCU } & \text { Upper clastic confining unit } \\ \text { UGTA } & \text { Underground Test Area } \\ \text { UTM } & \text { Universal Transverse Mercator } \\ \text { VA } & \text { Volcanic aquifer } \\ \text { VCU } & \text { Volcanic confining unit } \\ \text { VU } & \text { Undifferentiated volcanic rocks } \\ \text { YMP } & \text { Yucca Mountain Project }\end{array}$




\title{
A Three-Dimensional Numerical Model of Predevelopment Conditions in the Death Valley Regional Ground-Water Flow System, Nevada and California
}

\author{
By Frank A. D'Agnese, Grady M. O'Brien, Claudia C. Faunt, Wayne R. Belcher, and \\ Carma San Juan
}

\section{ABSTRACT}

In the early 1990's, two numerical models of the Death Valley regional ground-water flow system were developed by the U.S. Department of Energy. In general, the two models were based on the same basic hydrogeologic data set. In 1998, the U.S. Department of Energy requested that the U.S. Geological Survey develop and maintain a ground-water flow model of the Death Valley region in support of U.S. Department of Energy programs at the Nevada Test Site. The purpose of developing this "second-generation" regional model was to enhance the knowledge and understanding of the ground-water flow system as new information and tools are developed. The U.S. Geological Survey also was encouraged by the U.S. Department of Energy to cooperate to the fullest extent with other Federal, State, and local entities in the region to take advantage of the benefits of their knowledge and expertise.

The short-term objective of the Death Valley regional ground-water flow system project was to develop a steady-state representation of the predevelopment conditions of the ground-water flow system utilizing the two geologic interpretations used to develop the previous numerical models. The long-term objective of this project was to construct and calibrate a transient model that simulates the ground-water conditions of the study area over the historical record that utilizes a newly interpreted hydrogeologic conceptual model. This report describes the result of the predevelopment steady-state model construction and calibration.

The Death Valley regional ground-water flow system is situated within the southern Great Basin, a subprovince of the Basin and Range physiographic province, bounded by latitudes 35 degrees north and 38 degrees 15 minutes north and by longitudes 115 and 118 degrees west. Hydrology in the region is a result of both the arid climatic conditions and the complex geology. Ground-water flow generally can be described as dominated by interbasinal flow and may be conceptualized as having two main components: a series of relatively shallow and localized flow paths that are superimposed on deeper regional flow paths. A significant component of the regional ground-water flow is through a thick Paleozoic carbonate rock sequence. Throughout the flow system, ground water flows through zones of high transmissivity that have resulted from regional faulting and fracturing.

The conceptual model of the Death Valley regional ground-water flow system used for this study is adapted from the two previous groundwater modeling studies. The three-dimensional digital hydrogeologic framework model developed for the region also contains elements of both of the hydrogeologic framework models used in the previous investigations. As dictated by project scope, very little reinterpretation and refinement were made where these two framework models 
disagree; therefore, limitations in the hydrogeologic representation of the flow system exist. Despite limitations, the framework model provides the best representation to date of the hydrogeologic units and structures that control regional ground-water flow and serves as an important information source used to construct and calibrate the predevelopment, steady-state flow model.

In addition to the hydrogeologic framework, a complex array of mechanisms accounts for flow into, through, and out of the regional ground-water flow system. Natural discharges from the regional ground-water flow system occur by evapotranspiration, springs, and subsurface outflow. In this study, evapotranspiration rates were adapted from a related investigation that developed maps of evapotranspiration areas and computed rates from micrometeorological data collected within the local area over a multiyear period. In some cases, historical spring flow records were used to derive ground-water discharge rates for isolated regional springs.

For this investigation, a process-based, numerical model was developed to estimate net infiltration. This result can be used to represent recharge by assuming that water that infiltrates past the "root zone" ultimately becomes groundwater recharge. Net infiltration based on this water-balance approach, however, suggests that recharge in the region exceeds the estimated ground-water discharge for the basin by almost a factor of four. The net infiltration model contains some assumptions and was limited in regard to soil moisture, bedrock permeability, and precipitation distributions that result in these higher than expected values. Despite this limitation, the net infiltration model does provide a good starting point for estimating regional ground-water recharge in the ground-water flow model.

The Death Valley regional ground-water flow system was simulated using a three-dimensional steady-state model that incorporated a nonlinear least-squares regression technique to estimate selected model parameters. The numerical modeling program MODFLOW-2000 was used in creating a finite-difference model consisting of 194 rows, 160 columns, and 15 layers. The grid cells were oriented northsouth and were of uniform size, with side dimensions of 1,500 meters. The layers span thicknesses of 50 to 300 meters. The model grid encompasses about 70,000 square kilometers.

The required initial model parameter values were supplied by discretization of the threedimensional hydrogeologic framework model and digital representations of the remaining conceptual model components. The three-dimensional simulation and corresponding sensitivity analysis supported the hypothesis of interactions between a relatively shallow local and subregional flow system and a deeper dominant regional system controlled by the carbonate aquifer.

During calibration of the model, techniques available in MODFLOW-2000 allowed for estimation of a series of parameters that provided a best fit to observed hydraulic heads and flows. Numerous conceptual models were evaluated to test the validity of various interpretations about the flow system. Only those conceptual model changes contributing to a significant improvement in model fit, as indicated by a reduction in the sum of squared errors, were retained in the final optimized model. The final model was evaluated to assess the likely accuracy of simulated results by comparing measured and expected quantities with simulated values. Evaluation of the model indicates that although the model is clearly an improvement on previous representations of the flow system, there is an indication of important uncertainties and model error.

\section{INTRODUCTION}

In the early 1990's, two numerical models of the Death Valley regional ground-water flow system (fig. 1) were developed by the U.S. Department of Energy (DOE). One model was developed collaboratively for the Yucca Mountain Site Characterization Office (DOE/YMSCO) and the Nevada Operations Office Hydrologic Resource Management Project (DOE/NV-HRMP). Another was developed for the 


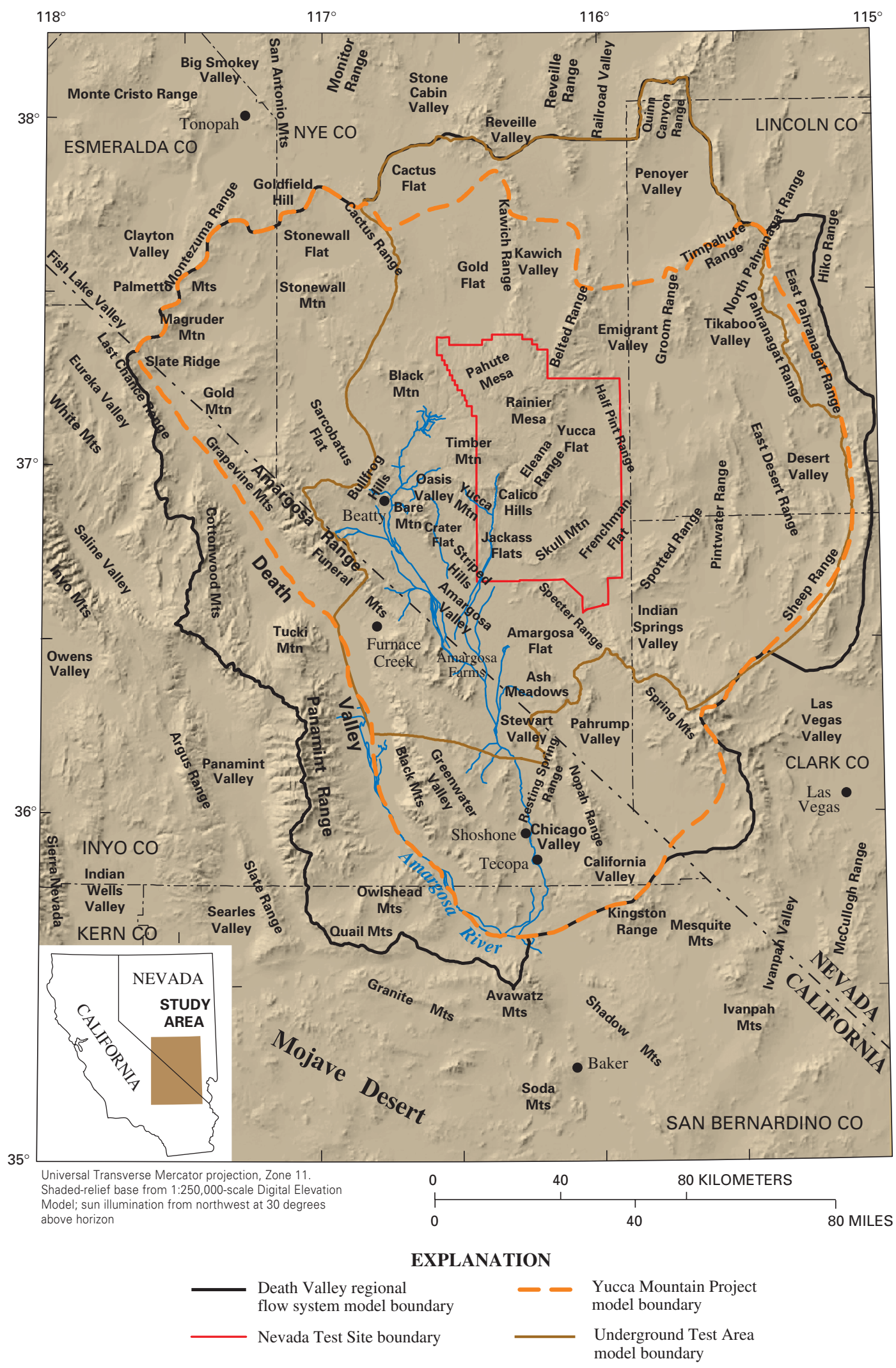

Figure 1. Graphic and prominent topographic features of the Death Valley region, Nevada and California. 
Nevada Operations Office Underground Test Area (DOE/NV-UGTA) subproject of the Environmental Restoration (ER) Project (fig. 1). The regional model for the DOE/YMSCO and DOE/NV-HRMP, referred to in this report as the Yucca Mountain Project (YMP) model, was developed by the U.S. Geological Survey (USGS) using MODFLOWP (Hill, 1992) and is documented in D'Agnese and others (1997). The model for the DOE/NV-UGTA, referred to in this report as the UGTA model (U.S. Department of Energy, 1997), was developed by the ER Support Services Contractor (IT Corporation and its subcontractors) using MODFLOW (McDonald and Harbaugh, 1988).

In general, the two models are based on the same basic hydrologic data set. The geologic data sets differ somewhat in detail of interpretation, but the same general hydrogeologic framework is apparent in both models. Significant differences of geologic interpretation occur in the hydrogeologic framework where data are sparse and results are highly interpretive. Estimates of recharge are also highly interpretive and vary significantly throughout the model domains. These differences affect both ground-water flow paths and flux through the models.

In 1998, the DOE requested that the USGS develop and maintain a ground-water flow model of the Death Valley regional ground-water flow system in support of DOE/YMSCO and DOE/NV programs. The purpose of developing this "second-generation" regional model was to enhance the knowledge and understanding of the Death Valley regional groundwater flow system as new information and tools are developed. Furthermore, the USGS has been encouraged by DOE to cooperate to the fullest extent with other Federal, State, and local entities in the region, including the National Park Service, the U.S. Fish and Wildlife Service, the Bureau of Land Management, and Nevada and California counties, to take advantage of the benefits of their knowledge and expertise.

Short-term objectives of the Death Valley regional ground-water flow system project include the construction and calibration of a steady-state model that approximates predevelopment conditions for the Death Valley regional ground-water flow system that may (1) provide the foundation and boundary conditions for the site-scale models at Yucca Mountain and the Underground Test Areas on the Nevada Test Site (NTS), (2) characterize regional three-dimensional (3D) ground-water flow paths, (3) define discharge and recharge locations, (4) estimate magnitude of subsurface flux, and (5) represent the effects of regional geologic structural features on regional flow.

Long-term objectives of the Death Valley regional ground-water flow system project involve the construction and calibration of a transient model that simulates the ground-water conditions of the study area over time and that could be utilized to: (1) evaluate the effects of changes in system flux, regardless of whether the changes are natural or human-induced; (2) provide a technical basis for decisions on the quantity of water available for defense and economic development activities on the NTS; (3) determine the potential effect of increased offsite water use on the NTS water supplies; (4) provide a framework for determining effective source plume, ambient trend, and point-of-use ground-water quality monitoring locations; and (5) provide an opportunity for other Federal, State, and local agencies and organizations to take a step toward developing a cooperative, regional Death Valley Ground-Water Management District.

\section{Purpose and Scope}

The purpose of this report is to document progress to date of the numerical steady-state groundwater flow model being developed as part of the Death Valley regional ground-water flow system project. The ground-water flow model simulates assumed predevelopment conditions. This groundwater flow model has been constructed from a data set synthesized from the previous two DOE regional ground-water model investigations. The results of this flow model will change as modifications are made to incorporate additional hydrogeologic data.

The scope of this study can be summarized as follows:

1. The study is limited to the Death Valley region, and the model domain, referred to as the Death Valley regional flow system (DVRFS), approximates the combined areas of the previous two DOE regional ground-water flow models (fig. 1).

2. The details of the hydrogeologic framework are limited to a "hard merge" of the existing two regional hydrogeologic interpretations. Therefore, no additional reinterpretation of regional hydrogeology was conducted. The details of the 
hydrogeologic framework "hard merge" effort are described in Belcher and others (2002).

\section{SITE DESCRIPTION}

The Death Valley region (fig. 1) includes several large, prominent valleys: Amargosa Valley, Pahrump Valley, and Death Valley. The region also includes several major mountain ranges including the Panamint Range, the Spring Mountains, the Sheep Range, the Amargosa Range, the Kawich Range, the Kingston Range, the Pahranagat Range, the Timpahute Range, and the Last Chance Range. These major physiographic and geologic features result in a complex ground-water flow system.

\section{Physiography}

The Death Valley region is situated within the southern Great Basin, a subprovince of the Basin and Range physiographic province (Fenneman, 1931). Late Cenozoic tectonic activity and faulting account for much of the topographic relief (Grose and Smith, 1989). Altitudes range from $86 \mathrm{~m}$ below sea level at Death Valley to 3,600 $\mathrm{m}$ above sea level at Charleston Peak in the Spring Mountains. The relief between valleys and adjoining mountains locally exceeds 1,500 $\mathrm{m}$ (Bedinger and others, 1989). Most of the principal mountain ranges have distinct northwestsoutheast (NW/SE) trends, although the trends of intermediate-scale topographic features are quite variable. The ranges occupy only about 25 percent of the landscape in the study area (Peterson, 1981). The remainder of the landscape is occupied by broad intermontane basins formed from tectonically downdropped grabens. The basins are filled with alluvium and some interbedded volcanic deposits that gently slope from the valley floors to the bordering mountain ranges forming piedmonts (Peterson, 1981).

The valley floors are local depositional centers, usually containing playa lakes that act as catchments for surface-water runoff (Grose and Smith, 1989). The Amargosa River (fig. 1), an intermittent stream whose drainage basin encompasses about $15,000 \mathrm{~km}^{2}$, discharges into the south end of the Death Valley saltpan, the largest playa in the study area (Hunt and others, 1966). Most of the basins seldom contain perennial surface water. Playas and alluvial flats lying within these basins constitute about 10 percent of the region (Bedinger and others, 1989). Numerous playas contain saline deposits that indicate the evaporation of surface water and(or) shallow ground water from the playa surface. Some of the playas that have been deformed by Quaternary faulting contain springs where ground water is forced to the surface by juxtaposed lake sediments and alluvial aquifers (Bedinger and others, 1989).

\section{Climate}

Climatic conditions in the Death Valley region are controlled by both altitude and latitude. The northern part of the region, including the Cactus, Kawich, and Timpahute Ranges (fig. 1), forms part of the Great Basin Desert, which is characterized by warm, dry summers and cold, dry winters. The southern part of the region, including Death Valley and the eastern Mojave, forms part of the Mojave Desert, which is characterized by hot, dry summers and warm, dry winters (Benson and Darrow, 1981). The central region around the NTS has been called the Transition Desert (Beatley, 1976), which represents a mixing of the two climates (fig. 2).

Precipitation in the region is influenced by two distinct storm patterns affecting the desert climateone in the winter, the other in summer. Winter precipitation (dominantly snow) tends to be of low intensity and long duration and covers large areas. In contrast, most summer rains result from localized convective thunderstorms of high intensity and short duration (Hales, 1972; 1974).

Quiring (1965) and French (1983) analyzed the distribution of precipitation resulting from the winter and summer weather regimes across southern Nevada. Quiring (1965) concluded that two sources (one winter and one summer) of precipitation can be identified (fig. 3). Precipitation resulting from these moisture sources, which affect regions south of latitude 38.5 degrees north, is influenced by major orographic and topographic controls. As a consequence, some areas of southern Nevada receive a precipitation excess while other areas receive a precipitation deficit relative to mean annual precipitation (French, 1983). 


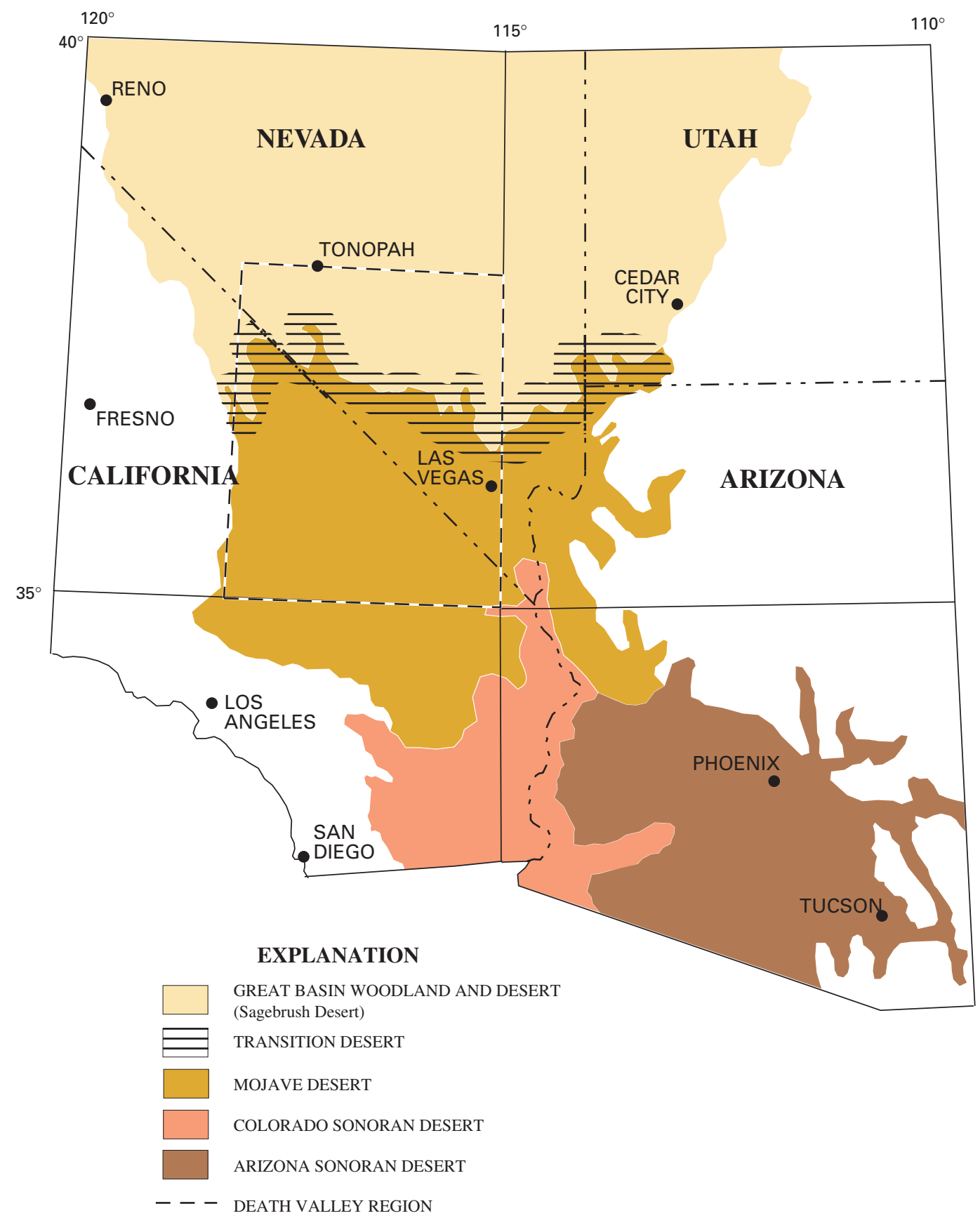

Figure 2. Desert climatic zones of the Death Valley region.

\section{Soils and Vegetation}

The soils and vegetation of the Death Valley region are controlled to a significant degree by climatic, geomorphic, and hydrologic factors. These relations are highly variable and complex.

Soils in the Death Valley region typically follow a pattern of lithosols on the mountains, medium- to coarse-textured soils on alluvial fans and terraces, and fine-grained, alluvial soils in the valley floors. In general, the soils of the mountains and hills are shallow and have a coarse texture with little moistureholding capacity. The soils of the alluvial fans on the upper bajadas also are coarse textured but are much deeper, so infiltration rates are relatively high. Infiltration rates of the alluvial basin soils are slow because the downward movement of water is often impeded by indurated calcium carbonate layers (pedogenic carbonate), fine-grained playa deposits, and, more 


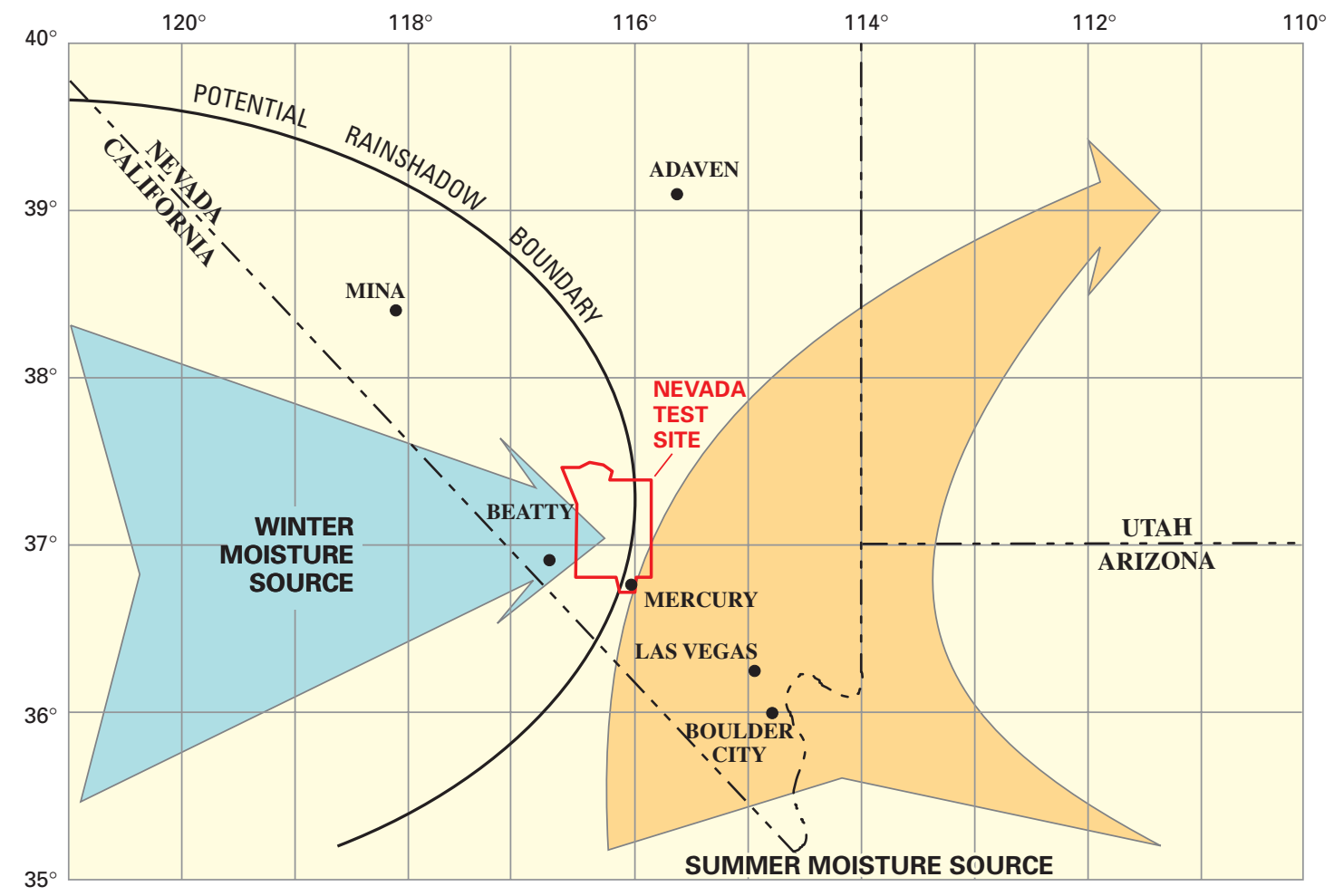

Figure 3. Weather regimes of the Death Valley region (Quiring, 1965).

infrequently, by silicified hardpans that form within the soils over time (Beatley, 1976).

Vegetation distributions in the Death Valley region are influenced by many factors. Water availability and temperature exhibit latitudinal and altitudinal controls that are dominantly climate related. Thus, vegetation communities in the region demonstrate both topographic and geographic patterns. Mixing of the cold, northern Great Basin Desert climate with the warm, southern Mojave Desert climate results in a heterogeneous distribution of plant associations, rather than distinct homogeneous associations (Beatley, 1976).

\section{Geologic Setting}

The Death Valley region has a long and active geologic history, including intermittent marine and nonmarine sedimentation, large-scale compressive deformation, plutonism, volcanism, and extensional tectonics (Stewart, 1980; Mifflin, 1988). Knowledge of the geologic diversity beneath the alluvial basins is indirect in most of the region.
The Death Valley region consists of clastic and crystalline rocks of Middle Proterozoic crystalline rocks to Early Cambrian clastic rocks; carbonate and clastic rocks of Paleozoic age; clastic, volcanic, and intrusive rocks of Mesozoic age; varied fluvial, paludal, and playa sedimentary deposits of Pliocene age; Tertiary volcanic, volcaniclastic, and sedimentary rocks; and Tertiary to Quaternary alluvium and colluvium and eolian deposits of Quaternary age (Waddell, 1982). Literature on detailed geologic studies throughout this region is voluminous; yet only a few integrative, comprehensive, and summary papers exist that cover the entire region and address all of the structural-tectonic-volcanic elements incorporated in the framework. Burchfiel and Davis (1981) discussed tectonic regimes in the California area, and Stewart (1978) discussed the tectonics of the Nevada part of the region concisely and comprehensively using structural mechanics principles. Grose and Smith (1989) described this geologic complexity and offered insight into the hydrogeologic and tectonic controls on ground-water flow. Wernicke and others (1988) have addressed the Cenozoic extensional history of the region; Carr (1990) attempted to integrate the Ceno- 
zoic volcanic history with the extensional history. Most of the study area has undergone deformation, and some parts have been nearly continuously tectonically active since the Late Proterozoic (Grose and Smith, 1989).

Structural and tectonic features of the study area (fig. 4) reveal a long, complex tectonic evolution. Combinations of normal, reverse, and strike-slip faulting and folding episodes have resulted in complex distributions of rocks. Consequently, diverse rock types, ages, and deformational structures are often juxtaposed. As a result, subsurface conditions are variable and complex.

\section{Proterozoic and Paleozoic Time}

Metamorphic basement rocks of Middle Proterozoic age were deposited approximately 1.7 to 1.4 billion years ago in geosynclinal, orogenic, and magmatic arc-type terranes. Sedimentation patterns were also influenced by the NE/SW-trending transcontinental arch. During the Late Proterozoic, the study area underwent a period of continental margin rifting (Grose and Smith, 1989).

This region was a stable, continental margin from Late Proterozoic to Devonian time. Late Proterozoic to Early Cambrian continental quartzites and siltstones are overlain by Middle Cambrian through Devonian carbonate and calcareous shales in a westward-thickening clastic and carbonate sequence up to $8,000 \mathrm{~m}$ in thickness. The first major Phanerozoic tectonic event in the Death Valley region was the Antler orogeny. During the Antler orogeny (Devonian to Mississippian time), uplift north and west of the area resulted in a thick wedge of clastic rocks, derived from adjacent highlands, being deposited in a NE/SWtrending foreland basin. Shelf-type carbonate deposition continued during Mississippian time in the southeast part of the region (for example, the Spring Mountains). This basin is now defined by the location of the Chainman Shale, which dominantly consists of relatively impermeable argillites and shales. The Antler orogeny also caused eastward thrusting of a more than 100,000-m-thick allocthon of deep-ocean shales, chert, and volcanic rocks. The leading edge of the Roberts Mountain thrust, formed during the Antler orogeny, is in the northwestern part of the Death Valley region (Grose and Smith, 1989). During Pennsylvanian time, the basin was filled, and shallow marine carbonates were deposited on the Mississip- pian-aged clastic rocks. As a result of these events, more than 10,600 m of Paleozoic and Late Proterozoic sediments were deposited over the area (U.S. Department of Energy, 1997).

\section{Mesozoic Time}

The Sonoma orogeny (Late Permian and Early Triassic time) resulted in the overthrusting of deepocean siliceous volcanic rocks toward the continent. Structures associated with the Sonoma orogeny occur mainly in the northwestern part of the Death Valley region (fig. 4). These events created scattered terranes of early Mesozoic metasedimentary and metavolcanic rocks. The Sevier orogeny (Middle Jurassic and Late Cretaceous time) affected the entire area by contraction with regional detachments and was highlighted by north-south-trending thrust faulting (including the Pahranagat Range, Gass Peak, Lee Canyon, and Keystone thrusts within this study area) and simultaneous intrusions of granites of Mesozoic age throughout the Death Valley region (Grose and Smith, 1989) (fig. 4). Wernicke and others (1988) have documented that some of this thrusting activity may be as old as the Permian.

\section{Tertiary and Quaternary Time}

In contrast to earlier compressional tectonism, regional uplift, erosion, volcanism, and extension occurred in the Tertiary. As a result, the Death Valley region now includes numerous north-south-trending valleys containing continental alluvial, paludal, and colluvial materials that are interstratified with lava flows, tuffs, and tuffaceous sediments. The study area underwent intense volcanism during the middle to late Tertiary period and was heavily scarred by massive volcano-tectonic and caldera depressions and voluminous ash flows of the Southwest Nevada Volcanic Field (SWNVF) (Byers and others, 1976; Sawyer and others, 1994). Successive eruptions produced at least seven large, partially overlapping calderas, which were filled with syneruptive welded tuffs and posteruptive lava flows and which blanketed surrounding older rocks with vast deposits of tuff (U.S. Department of Energy, 1997). The SWNVF has significantly affected parts of the area either by altering or completely removing the preexisting rocks. Meanwhile, water levels in pluvial lakes rose and fell in response to climate fluctuations, and deposition of basin-fill 


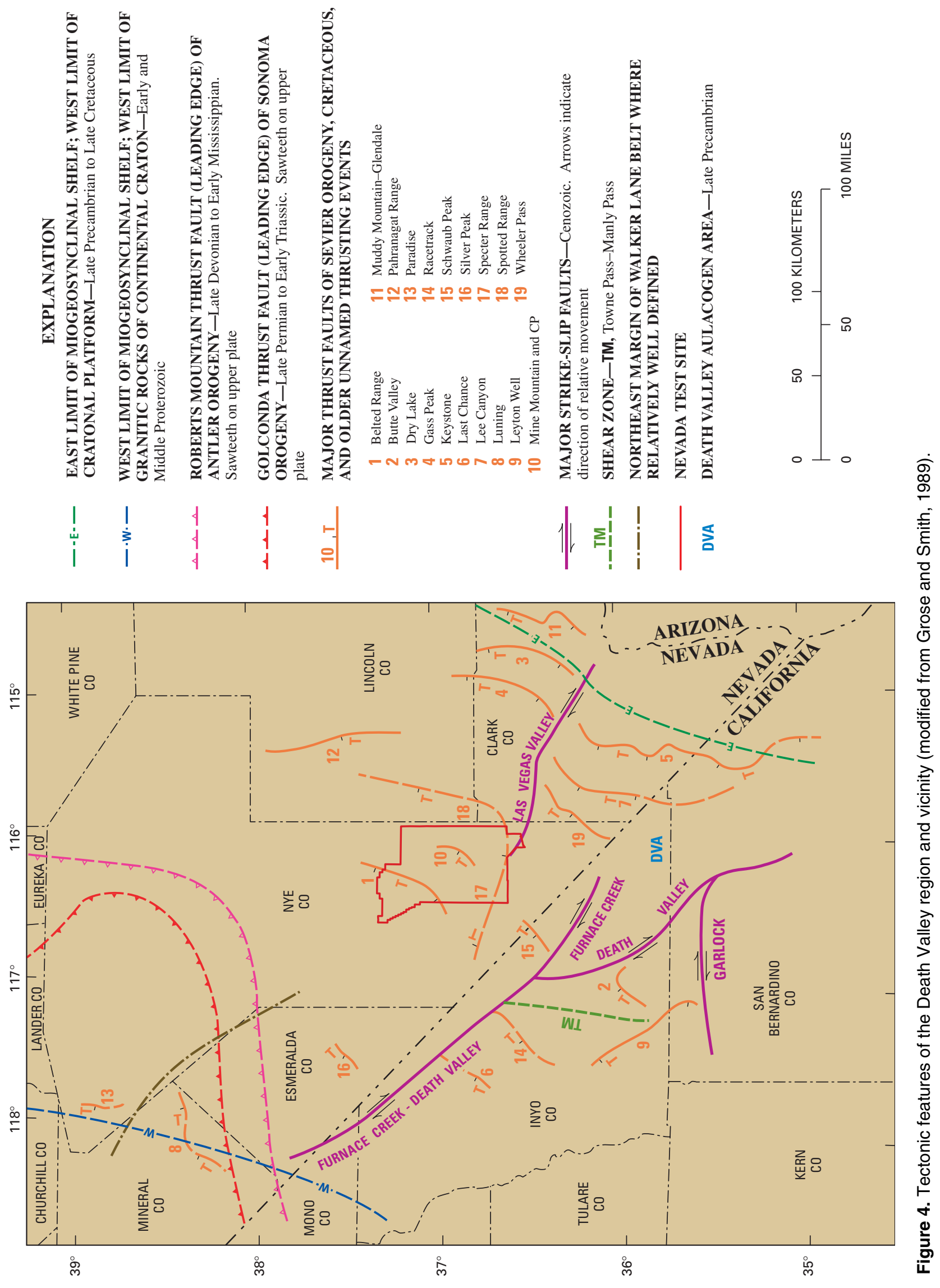


material continued. Modern alluvial basins have been filled with as much as 3,000 m of coarse gravels, sands, and localized deposits of playa silt and clay.

\section{Tertiary and Quaternary Tectonics}

Superimposed on the earlier pre-Tertiary structural features, the area in and around the NTS began to be pulled apart along normal and strike-slip faults associated with the formative stages of the modern Basin and Range (U.S. Department of Energy, 1997). Together with the volcanic features, these attributes dominate the topography and physiography of the present-day study area (Grose and Smith, 1989). According to Dickinson and Snyder (1979), basin and range deformation occurred in two phases. The first phase began during late Eocene time and ended during middle Miocene time and is associated with the deposition of silicic volcanic rocks. The second phase of extensional tectonics was characterized by reduced volcanic activity and was important in shaping present-day topography. Late Cenozoic tilting and warping are also evident (Grose and Smith, 1989). Tectonic activity in the Basin and Range Province has continued to historical times, as indicated by historical faulting in the study area. Carr (1984) suggested that basin and range deformation has decreased in the last few million years because the amount of offset along normal faults decreases near the surface.

The basin and range tectonics are superimposed on the Walker Lane Belt, a NW/SE-trending, rightlateral, strike-slip shear zone located near the southern Nevada-California border (Locke and others, 1940; Longwell, 1960; Stewart, 1971, 1978). The Walker Lane Belt is part of a megastructure that crosses the Basin and Range Province from Texas to Oregon (Carr, 1990). The Walker Lane Belt separates the NW/SE structural-physiographic trends in the southwestern Great Basin, east of the Sierra Nevada, from the predominantly north-south trend of the more typical basin and range structure. The Walker Lane Belt has long been recognized as an area of active faulting containing patterns of faults that are anomalous with respect to the typical fault patterns in the Great Basin (Stewart, 1988). The Walker Lane Belt is dominated by strike-slip rather than dip-slip faulting; and except for caldera structures, large vertical displacements are not characteristic (Carr, 1990). The Las Vegas Valley shear zone and the Furnace Creek-
Death Valley fault system (fig. 5) are major structural features associated with the Walker Lane Belt.

Within the study area, structural trends, styles, and tectonic activity (Carr, 1990) of the southern Great Basin are diverse. Carr divided the area into three major structural-physiographic subsections: the InyoMono, the Walker Lane, and Basin and Range (fig. 5). Within these subsections are two NE/SW-trending structural zones: the Spotted Range-Mine Mountain zone and the Pahranagat shear zone (fig. 5). Winograd and Pearson (1976) refer to a major potentiometric trough. The location of the trough is probably structurally controlled (Winograd and Thordarson, 1975, p. C71-C74) and is roughly coincident with part of the Spotted Range-Mine Mountain zone.

In addition to the Spotted Range-Mine Mountain zone and the Pahranagat shear zone, the Walker Lane Belt also contains a number of somewhat lessdefined NE/SW-trending structural zones. Because they contain highly fractured rocks with potentially large transmissivity, these less-defined zones may influence regional ground-water flow patterns (Faunt, 1994; Carr, 1984). These less-defined zones include NE/SW-trending structural lineaments from the Bullfrog Hills across the Timber Mountain caldera complex (fig. 5), a similar trend from the southern Sarcobatus Flat to Black Mountain Caldera (fig. 5), and a NE/SW structural-topographic trend from Death Valley through the Gold Mountain-Slate Ridge area to Stonewall Flat (fig. 5).

\section{Hydrology}

In the Death Valley region, perennial streamflow is virtually nonexistent. Several perennial streams originate from snowmelt in the high altitudes of the Spring and Magruder Mountains. These streams have highly variable base flows and in dry years have almost imperceptible discharges. Perennial streams fed from springs along the lower reaches of the Amargosa River have the most consistent surface-water base flows. Despite the small surface-water component, the Death Valley region has been delineated on the basis of surface-water or topographic divides into hydrographic areas that have been used for descriptive and accounting purposes in many surface-water and ground-water studies in the Great Basin (Eakin and others, 1976) (fig. 6). 


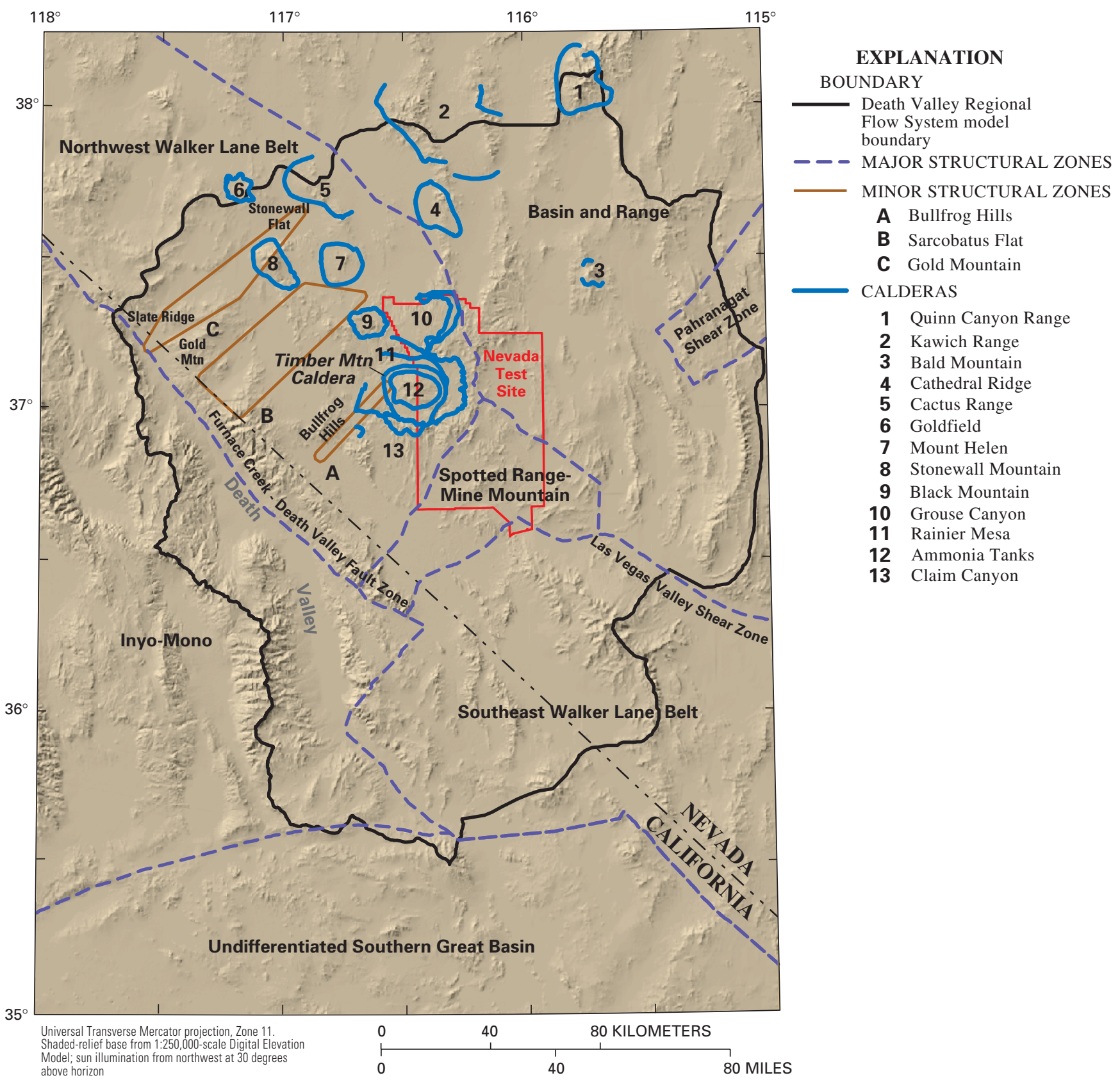

Figure 5. Structural-physiographic subsections of the Death Valley region (modified from Carr, 1990).

The ground-water flow systems of the Death Valley region are extremely complex. Hydraulic compartmentalization may occur throughout the study area due to the complex geologic structure. Interbasin flows control most of the regional ground-water flow system. Most ground-water recharge results from infiltration of precipitation and runoff on the high mountain ranges (Bedinger and others, 1989). Natural ground-water discharge is by flow to springs and by evapotranspiration (ET) in areas where the water table is near the land surface. Human-induced discharge occurs in the form of ground-water pumping for agricultural, commercial, and residential uses (Bedinger and others, 1989).

Regional ground-water flow patterns do not coincide with topographic basins; however, flow generally follows the regional topographic gradient and water generally moves toward Death Valley. A 


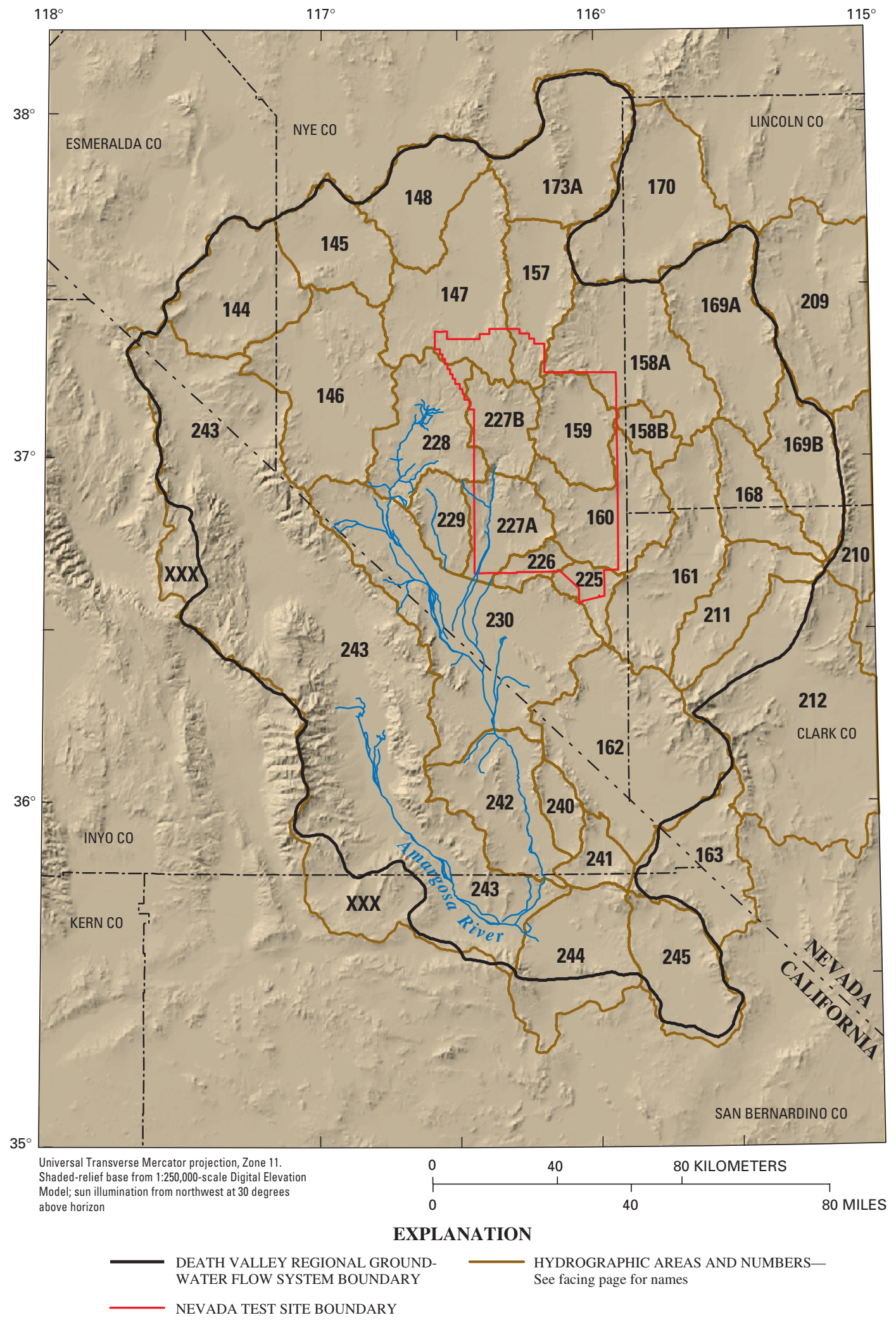

Figure 6. Hydrographic areas of the Death Valley region (modified from Eakin and others, 1976). 


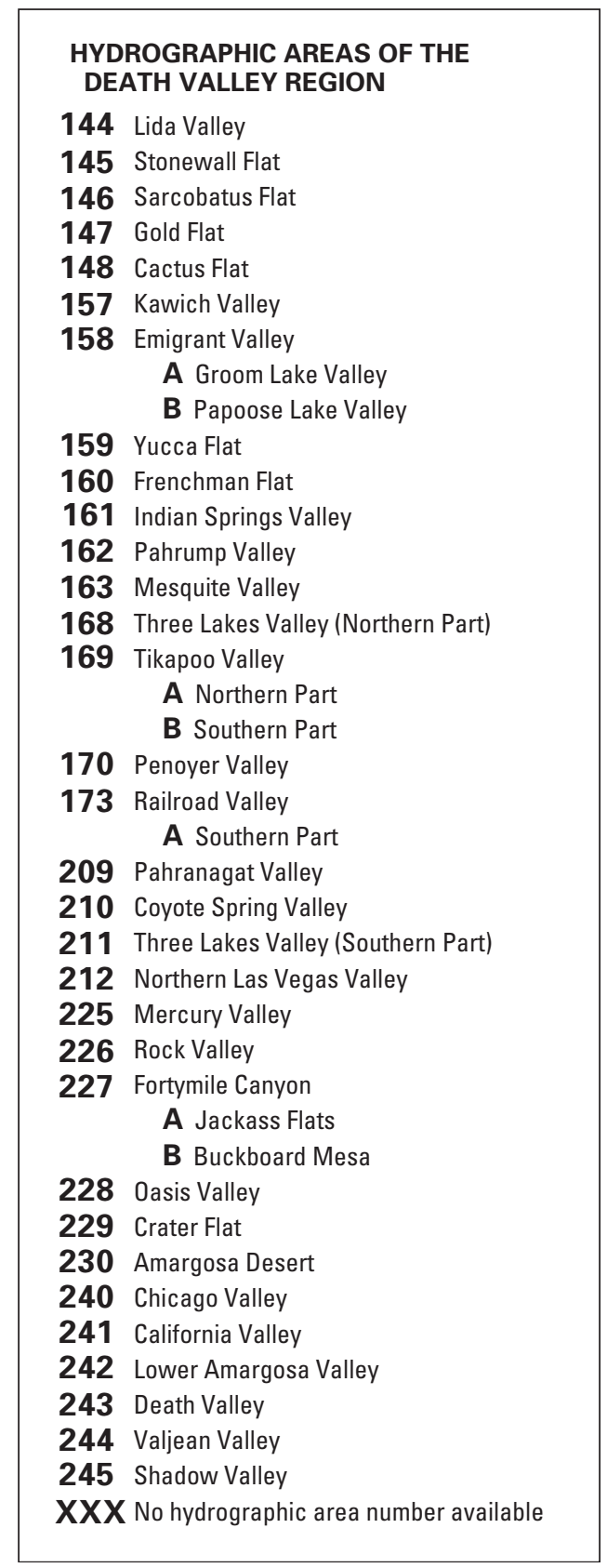

Figure 6. Hydrographic areas of the Death Valley region (modified from Eakin and others, 1976)-Continued.

laterally and vertically extensive carbonate rock sequence forms the most significant regional hydraulic control because it underlies the area. Most of the regional flow is affected by structurally and lithologically induced variations in permeability (Winograd and Thordarson, 1975). Regional flow is also affected by shallow local flow systems that are controlled by recharge and discharge locations and by the complex geology. In several places, high mountain ranges support local ground-water mounds; the mountain ranges may act as hydraulic barriers to subsurface flow, preventing interbasinal ground-water flow. The net result of these interactions is the compartmentalization of flow into local, subregional, and regional subsystems.

\section{Land and Water Use}

Most of the land in the Death Valley region is owned by the U.S. Government and is administered by numerous Federal agencies. Privately owned land is scattered throughout the region, but most private ownership is concentrated near the agricultural centers of Amargosa Valley and Pahrump Valley, the mines near Beatty, Nev., and the recreational gateways at Shoshone, Tecopa, and Baker, Calif. (fig. 1).

The major land-use activities in the region include agriculture, livestock ranching, recreation, and mining. Water within the basin mostly is utilized for domestic, commercial, agricultural, livestock, military, and mining purposes. Water resources in the basin directly support the natural diversity protected by the National Park Service in Death Valley and the U.S. Fish and Wildlife Service at Ash Meadows. These areas are protected because of the presence of rare desert oases containing endemic wildlife, such as the Devils Hole Pupfish (Cyprinidon Diabolis), whose continued existence depends on naturally occurring spring discharges.

\section{GROUND-WATER SYSTEM}

A conceptual model of the Death Valley regional ground-water flow system was developed by integrating interpretations from the two previous ground-water modeling studies (D'Agnese and others, 1997; U.S. Department of Energy, 1997). The following sections describe the boundaries of the ground-water flow system; the hydrogeologic framework of the ground-water system, including the hydrogeologic units and structures; the source, occurrence, and movement of water through the system; and an estimated water budget for the ground-water system under predevelopment conditions.

\section{System Boundaries}

The boundaries of the Death Valley groundwater flow system were defined by Harrill and Prudic 
(1998) and are shown in figure 7. The ground-water system is a 3D body of consolidated and unconsolidated rock that is saturated with ground water. This saturated volume of rock is bounded on all sides by a "boundary surface" (Franke and others, 1987). The boundary surface allows water to either flow into or out of the system, such as at the water table, or acts as a flow barrier, which allows little or no water to enter or leave the system across the boundary surface, such as at a ground-water divide or an impermeable mountain block.

The upper boundary surface of the Death Valley ground-water flow system is the water table. Under natural, or predevelopment conditions, ground water moves into the flow system across this boundary as regional ground-water recharge or out of the system across this boundary at natural ground-water discharge sites, such as springs, ET areas, and wet playas. Under stressed, or transient conditions, the upper boundary surface may fluctuate as a result of changes to groundwater recharge and discharge. The lower boundary surface is at a depth where ground-water flow is dominantly horizontal or parallel to the lower surface and moves with such small velocities that the volumes of water involved do not significantly impact regional flow estimates. The depth of this surface may vary and generally corresponds with the upper surface of small permeability basement rock.

The sides of the ground-water flow system may be either no-flow or flow boundaries. When the system is observed at steady-state, no-flow conditions exist where ground-water movement across the boundary is impeded by physical barriers, interpreted flow paths parallel to the boundary, or divergence of groundwater flow paths resulting in a ground-water divide. Flow paths and ground-water divides both may be altered as no-flow boundaries under nonsteady-state or steady-state conditions. Most of the Death Valley regional ground-water flow system is interpreted as having a no-flow boundary resulting from physical barriers (fig. 7). No-flow boundaries interpreted as resulting from ground-water divides occur in the area of northern Las Vegas Valley. Lateral flow boundaries exist where ground-water potentiometric gradients permit flow across a boundary through fractures or higher permeability zones. Lateral flow boundaries (underflow) include sections of the delineated boundary where ground water is interpreted to potentially flow into the system at southern Railroad Valley, Reveille Valley, Stone Cabin Valley, Mud Lake
(Ralston Valley), Fish Lake and Eureka Valleys, Saline Valley, Panamint Valley, Pilot Knob Valley, Pahranagat Valley, and northern Las Vegas Valley (fig. 7).

\section{Hydrogeologic Framework}

The hydrogeologic framework defines the physical geometry and composition of the surface and subsurface materials through which ground water flows. The framework defines the fundamental nature of the ground-water flow system and includes a definition of the regional topography, the hydrogeologic units, and the hydrogeologic structures in the region.

\section{Hydrogeologic Units}

In this report, the rocks and deposits forming the hydrogeologic framework are grouped into hydrogeologic units. A hydrogeologic unit has considerable lateral extent and has reasonably distinct hydrologic properties because of its physical (geologic and structural) characteristics. Although all the major geologic features are retained, many of the smaller geologic units were grouped into larger entities by generalizing both lithologic and hydrologic properties of the bedrock and basin-fill units.

Winograd and Thordarson (1975) developed a nomenclature for hydrogeologic units in the vicinity of the Nevada Test Site. In the DVRFS, the entire sequence of hydrogeologic units may or may not be present in some parts of the study area due to lack of deposition, normal or thrust faulting, low-angle extensional faulting, or melting and replacement from plutons or caldera formation.

In consolidated rocks, the distinction between aquifers and confining units is generally related to observations and assumptions of the degree to which stratigraphic units tend to be fractured. This fracturing is the result of both primary (such as cooling joints) and tectonic fractures.

The major units, defined by Winograd and Thordarson (1975), from oldest to youngest are the lower clastic aquitard (now termed the lower clastic confining unit [LCCU]), the lower carbonate aquifer (LCA), the Eleana confining unit (now termed the upper clastic confining unit [UCCU]), the upper carbonate aquifer (UCA), the tuff aquifers (now termed the volcanic aquifers [VA]), and volcanic aquitards (now termed the volcanic confining units 


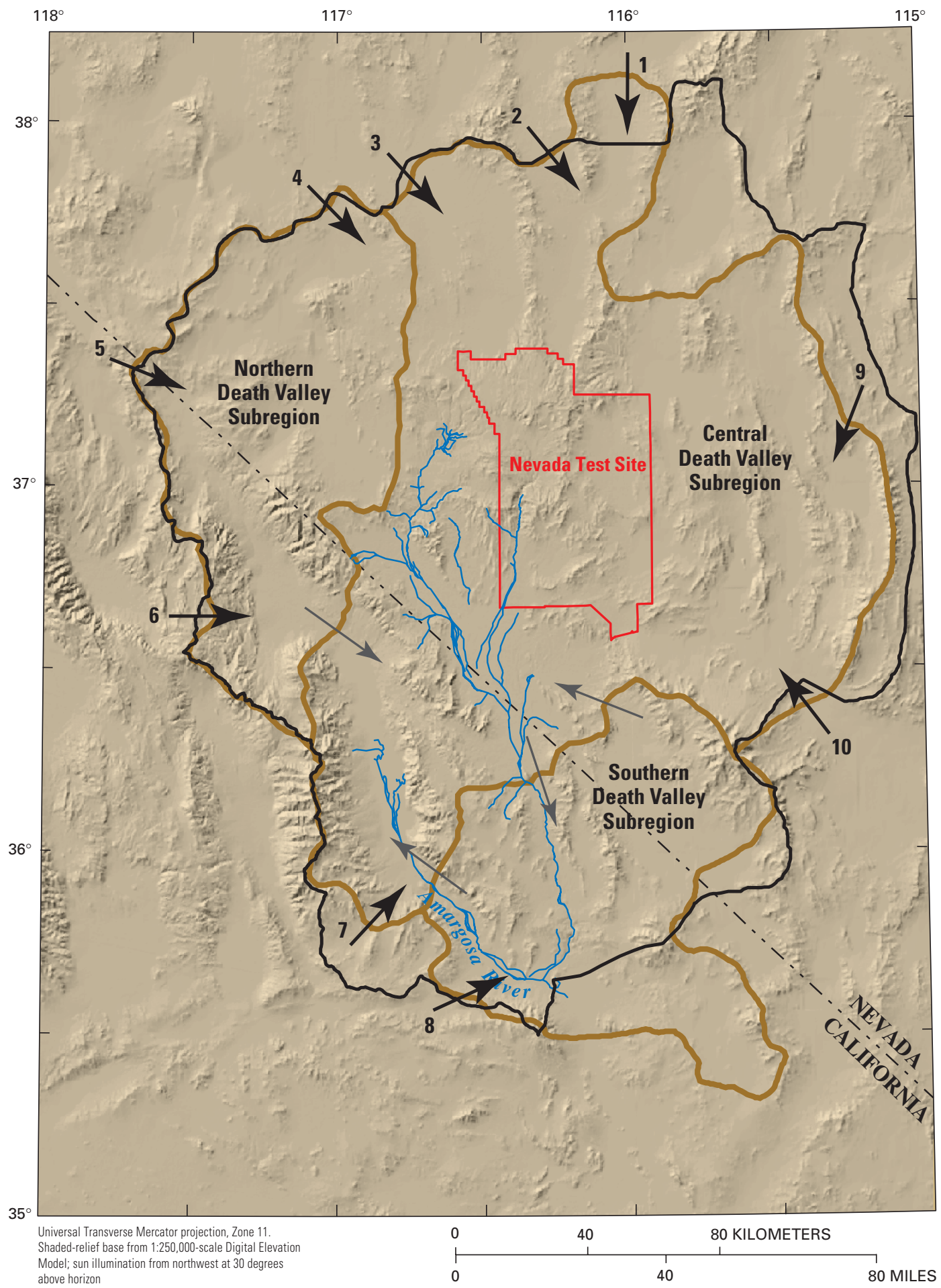

\section{EXPLANATION}

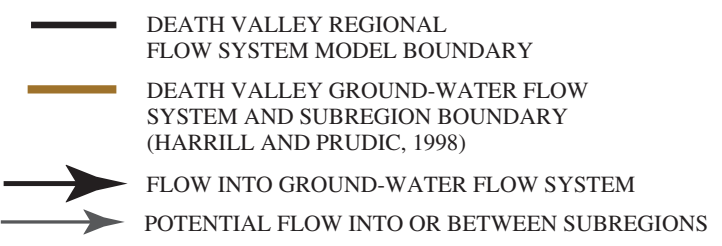

FLOW PATHS AND NUMBERS-

1 Southern Railroad Valley $\quad 6$ Saline Valley

2 Reveille Valley 7 Panamint Valley

3 Stone Cabin Valley (Cactus Flat) 8 Pilot Knob Valley

4 Ralston Valley (Mud Lake) 9 Pahranagat Valley

5 Fish Lake and Eureka Valleys 10 North Las Vegas Valley

Figure 7. Interpreted subregions, ground-water basins, and associated flow paths of the Death Valley regional ground-water flow system. 
[VCU]), and the alluvial aquifer (QTal). The LCCU forms the basement and is generally present beneath the other units except in caldera complexes. The LCA is the most extensive and transmissive unit in the region. It is present in most of the area, although it does not control ground-water flow within the caldera complexes. The UCCU is present in the north-central part of the NTS. It typically impedes vertical flow between the overlying UCA and underlying LCA, and is associated with many of the large hydraulic gradients in and around the NTS. The VA and VCU form a stacked series of alternating aquifers and confining units in and around the SWNVF. The VA are moderately transmissive and are saturated in the western sections of the NTS. The QTal forms a discontinuous, albeit important, aquifer in the region.

The zones of saturation in the hydrogeologic framework may be regional, semiperched, or perched. Regional ground-water flow occurs primarily within the LCA and VA. Perched ground water is present locally throughout the NTS and occurs locally within the tuffs wherever confining units compose ridges or hills that lie above the regional zone of saturation (Winograd and Thordarson, 1975).

The hydrogeologic units contained in the DVRFS framework model represent a combination of the hydrogeologic units contained in the YMP/HRMP hydrogeologic framework model (HFM) (D'Agnese and others, 1997, p. 17-20) and the hydrostratigraphic units contained in the UGTA Phase I geologic model (U.S. Department of Energy, 1997). Both of these framework models were loosely based on the hydrogeologic units defined by Winograd and Thordarson (1975). Table 1 presents the set of units used in both models and the resulting units used in the DVRFS HFM described in this report, including thrust-faulted units. Figure 8 shows the ground-surface (outcrop) distribution of hydrogeologic units. A detailed description of the hydrogeologic units included in the DVRFS HFM is found in the description of the 3D framework model section of the hydrogeologic framework model report (Belcher and others, 2002).

\section{Hydrogeologic Structures}

Hydrogeologic structures include faults, fractures, or joints that alter the physical framework of a region and, thus, influence ground-water flow. Faults in the Death Valley region may affect ground-water flow by acting as barriers, conduits, and combined conduit/barriers, or by offsetting strata of different hydrologic characteristics. Therefore, in addition to changes to the flow field resulting from the truncation of aquifers and confining units by offsets in the units, structures have two effects on ground-water flow: direct effects associated with alterations to flow rates and ground-water velocities within the faulted zone, and indirect effects associated with physical alterations to the flow field in the area near the faulted zone.

Caine and Forster (1999) summarized these as the fault core and the damaged zone. The fault core is the component of a fault zone where tectonics have altered the original lithology. In many cases, the core will have reduced permeability, relative to that of the adjacent damaged zone. The damaged zone is the network of subsidiary structures surrounding the fault core. They are composed of both open and filled fractures with the geometry and intensity of the fracturing resulting in heterogeneity and anisotropy in bulk permeabilities. The damaged zone's permeability is typically enhanced relative to both the fault core and the undeformed rock. Fault cores typically impede fluid flow across the fault, while the damaged zones typically conduct flow along the fault zone. So, depending on the direction of flow, the fault can be either a conduit or barrier (or combined conduit/ barrier) to flow.

The Death Valley region is typically a series of alluvial filled basins that are separated by ranges composed of consolidated bedrock. These basins and ranges are controlled by faults. In many cases, the juxtaposition of aquifers and confining units is sufficient to significantly affect the flow system. The regional aquifer can be faulted against a low-permeability material, forcing the water to the surface in the form of springs, such as those at Ash Meadows, or diffuse discharge.

A subset of the mapped faults in the Death Valley region was chosen to be incorporated as relative barriers in the flow model. These faults were chosen based on their orientation and length. Faults longer than $5 \mathrm{~km}$ and generally perpendicular to the ground- 
Table 1. Hydrogeologic units used in the Death Valley regional flow system model and in previous U.S. Department of Energy models in the Death Valley region

\begin{tabular}{|c|c|c|c|}
\hline $\begin{array}{l}\text { Hydrogeologic } \\
\text { unit }\end{array}$ & $\begin{array}{c}\text { UGTA unit } \\
\text { (U.S. Department } \\
\text { of Energy, } \\
1997)\end{array}$ & $\begin{array}{c}\text { YMP unit } \\
\text { (D'Agnese and } \\
\text { others, 1997) }\end{array}$ & Description of primary component \\
\hline QTal & AA & QTvf & Alluvium/Valley fill \\
\hline QTp & --- & Qp & Playa deposits \\
\hline VU & VU & QTv, Tv & Undifferentiated volcanic rocks \\
\hline VA & VA & QTv, Tv & Volcanic aquifer-southern Nevada Test Site \\
\hline VCU & VCU & QTv, Tv & Volcanic confining unit-southern Nevada Test Site \\
\hline TMA & TMA & QTv, Tv & Timber Mountain aquifer \\
\hline TC & $\mathrm{TC}$ & QTv, Tv & Timber Mountain-Paintbrush/Calico Hills tuff cone \\
\hline TCB & TCB & QTv, Tv & Timber Mountain-Bullfrog confining unit (nonwelded tuffs) \\
\hline TBA & TBA & QTv, Tv & Timber Mountain-Belted Range aquifer (welded tuffs) \\
\hline TBCU & TBCU & QTv, Tv & Timber Mountain-Basal confining unit (nonwelded tuffs) \\
\hline TBQ & TBQ & QTv, Tv & Timber Mountain-Basal aquifer (welded tuffs) \\
\hline TSDVS & TSDVS & Tvs & Tertiary sediments/Death Valley section \\
\hline Mvs & --- & Mvs & Mesozoic volcaniclastic and sedimentary rocks \\
\hline Mvs_LC & --- & Mvs & $\begin{array}{l}\text { Mesozoic volcaniclastic and sedimentary rocks-Lee Canyon } \\
\text { thrust }\end{array}$ \\
\hline Mvs_KS & --- & Mvs & $\begin{array}{l}\text { Mesozoic volcaniclastic and sedimentary rocks-Keystone } \\
\text { thrust }\end{array}$ \\
\hline $\mathrm{UCA}$ & LCA3 & --- & Upper carbonate aquifer \\
\hline UCCU & $\mathrm{UCCU}$ & ECU & Upper clastic confining unit \\
\hline LCA & LCA & $\mathrm{P} 2$ & Lower carbonate aquifer \\
\hline $\mathrm{LCCU}$ & $\mathrm{LCCU}$ & $\mathrm{P} 1 \mathrm{pCgm}$ & Lower clastic confining unit \\
\hline LCA_T2 & LCA_T1 & --- & $\begin{array}{l}\text { Lower carbonate aquifer-Specter Range and Wheeler Pass } \\
\text { thrusts (upper plate) }\end{array}$ \\
\hline LCCU_T2 & LCCU_T1 & --- & $\begin{array}{l}\text { Lower clastic confining unit-Schwaub Peak, Specter Range, } \\
\text { and Wheeler Pass thrusts (upper plate) }\end{array}$ \\
\hline LCA_LC & --- & --- & Lower carbonate aquifer-Lee Canyon thrust \\
\hline LCA_GP & --- & --- & Lower carbonate aquifer-Gass Peak thrust \\
\hline LCA_T1 & LCA_T2 & --- & $\begin{array}{l}\text { Lower carbonate aquifer-Schwaub Peak, Specter Range, and } \\
\text { Wheeler Pass thrusts (lower plate) }\end{array}$ \\
\hline LCCU_GP & --- & --- & Lower clastic confining unit-Gass Peak thrust \\
\hline LCCU_T1 & LCCU_T2 & --- & $\begin{array}{l}\text { Lower clastic confining unit-Schwaub Peak, Specter Range, } \\
\text { and Wheeler Pass thrusts (lower plate) }\end{array}$ \\
\hline $\mathrm{pCgm}$ & $\mathrm{LCCU}$ & $\mathrm{pCgm}$ & Precambrian granites and metamorphic rocks \\
\hline TJi & I & TJg & Tertiary-Jurassic intrusives \\
\hline
\end{tabular}

water flow direction were selected to be incorporated as relative barriers (fig. 9). As discussed before, in general, faults that are perpendicular to the general flow direction act as relative barriers to flow. In the Death Valley region these faults are typically oriented northwest-southeast. The Death Valley fault zone, Furnace Creek fault zone, Gravity fault, and the combined Amargosa River fault/Stewart Valley fault are all examples of the faults that impede flow and were incorporated into the flow model (fig. 9).

\section{Source, Occurrence, and Movement of Ground Water}

The source, occurrence, and movement of ground water in the Death Valley regional ground- 


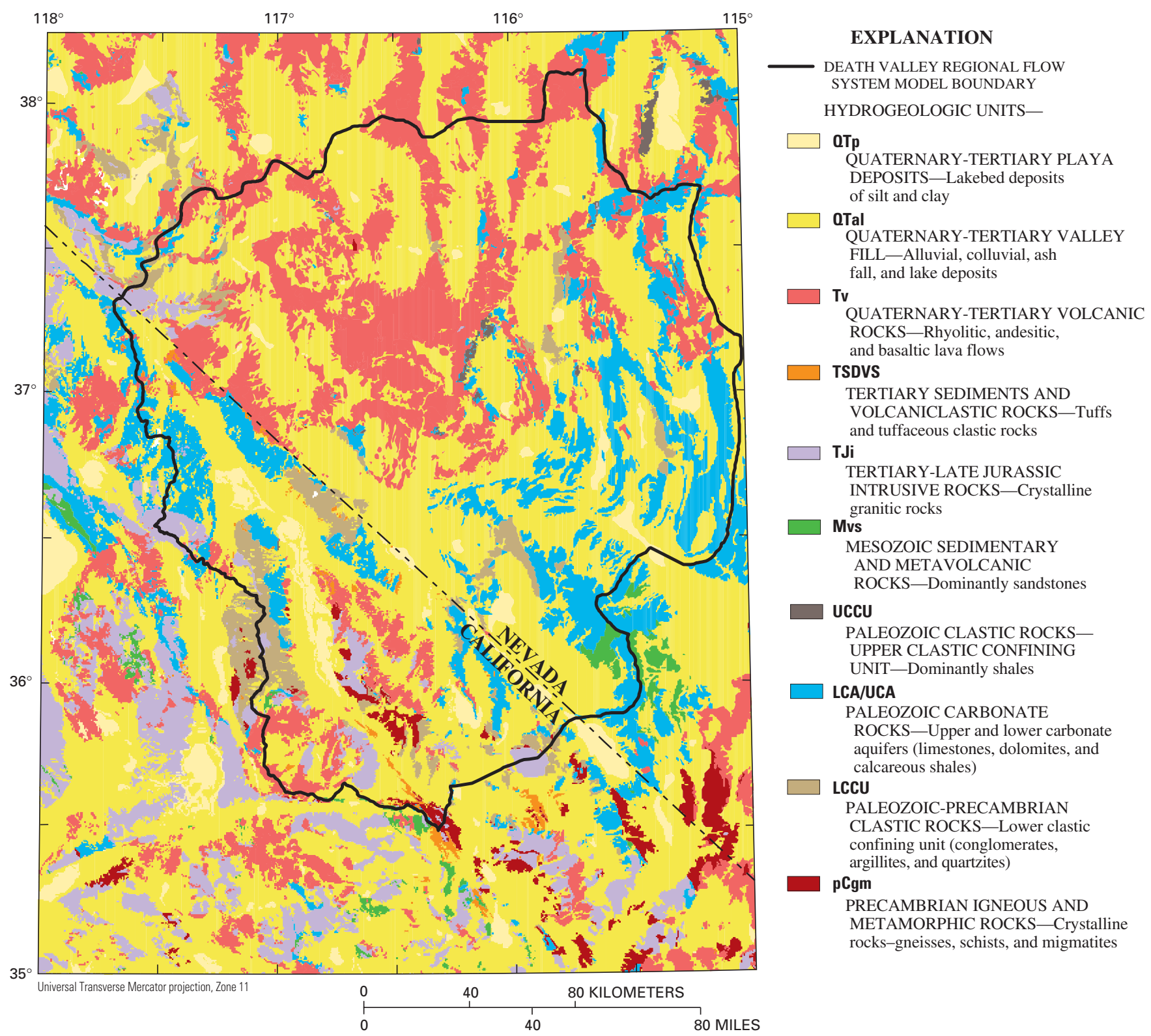

Figure 8. Hydrogeologic units of the Death Valley region (modified from Faunt and others, 1997).

water flow system has been described by numerous authors and was summarized by D'Agnese and others (1997, p. 62-69). That conceptual model is adapted for this investigation.

According to D'Agnese and others (1997) ground-water flow in the DVRFS is most easily described in terms of subregions. For convenience, the subregions are subdivided into ground-water basins and sections (fig. 7 and table 2). These boundaries are used for conceptual ease and descriptive purposes only, and these subregions, ground-water basins, and sections do not define known discrete independent flow systems. Much remains to be done to refine these subregions.

\section{Northern Death Valley Subregion}

Ground water in the Northern Death Valley subregion is derived from precipitation on high altitudes of the Montezuma Range and the Palmetto, Gold, and Stonewall Mountains. An unknown volume of ground water also may be entering the subregion across the system boundary from Mud Lake (Ralston Valley), Fish Lake and Eureka Valleys, and Saline Valley (fig. 7). 

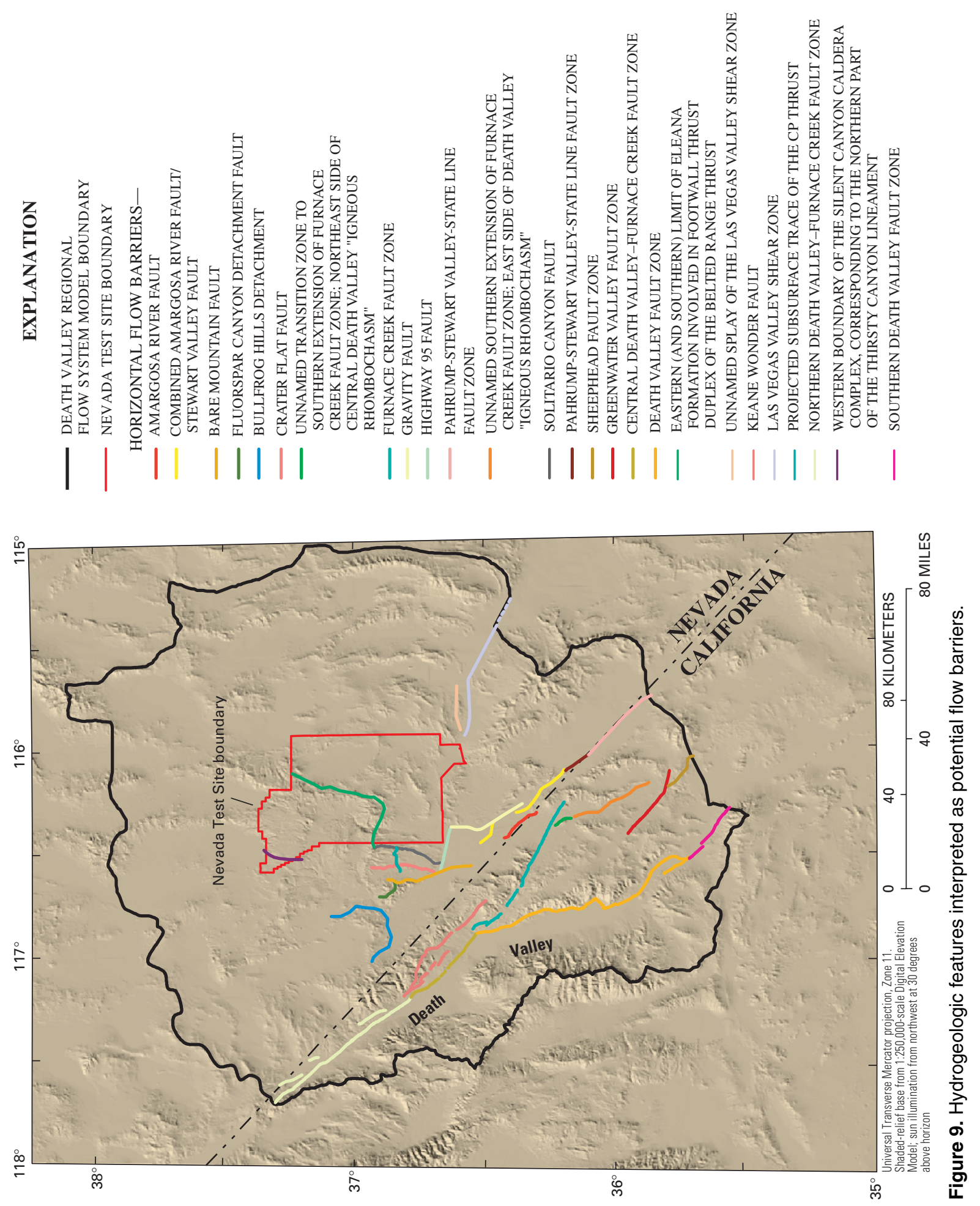
Table 2. Divisions of the Death Valley regional ground-water flow system

\begin{tabular}{l}
\hline NORTHERN DEATH VALLEY SUBREGION \\
Lida-Stonewall section \\
Sarcobatus Flat section \\
Grapevine Canyon-Mesquite Flat section \\
Oriental Wash section \\
CENTRAL DEATH VALLEY SUBREGION \\
Pahute Mesa-Oasis Valley ground-water basin \\
Southern Railroad Valley section \\
Kawich Valley section \\
Oasis Valley section \\
Ash Meadows ground-water basin \\
Pahranagat section \\
Tikaboo Valley section \\
Indian Springs section \\
Emigrant Valley section \\
Yucca-Frenchman Flat section \\
Specter Range section \\
Alkali Flat-Furnace Creek ground-water basin \\
Fortymile Canyon section \\
Amargosa River section \\
Crater Flat section \\
Funeral Mountains section \\
SOUTHERN DEATH VALLEY SUBREGION \\
Pahrump Valley section \\
Shoshone-Tecopa section \\
California Valley section \\
Ibex Hills section \\
Valjean Valley section \\
\hline
\end{tabular}

Ground water recharged on the mountains in the northwestern part of this subregion is interpreted to move toward the central axes of adjacent valleys. In this subregion, water levels indicate that much of the ground-water flow appears to be controlled by the NE/SW-trending structural zones described by Carr (1984). Deep, regional interbasinal flow is unlikely because the subregion is mostly underlain by relatively impermeable, shallow Tertiary intrusive granites and crystalline Proterozoic rocks. The regional carbonate aquifer is believed to be extensive and continuous only in the southeastern part of the subregion (Grose, 1983), near western Pahute Mesa and southern Sarcobatus Flat (fig. 10). Four dominant hydrostratigraphic sections contain the majority of flow in the basin: the Lida-Stonewall section, the Sarcobatus Flat section, the Grapevine Canyon-Mesquite Flat section, and the Oriental Wash section (fig. 10).

The Lida-Stonewall section (fig. 10) potentially receives underflow from Mud Lake and recharge from areas along the northern boundary of the subregion and transports it south to Sarcobatus Flat and Death
Valley. This section contains playa areas at Stonewall Flat and near Lida Junction. The trace amounts of ground water evapotranspired in these areas are believed to be derived mostly from local surface water.

The Sarcobatus Flat section (fig. 10) contains discharge areas at Sarcobatus Flat and Coyote Hole playas. These areas are believed to evapotranspire ground water that has moved along subregional flow paths. At Coyote Hole playas, impedance of groundwater flow by bedrock at shallow depths immediately south of the playas results in evapotranspiration of ground water that may originate on western Pahute Mesa (D'Agnese and others, 1997). As with the LidaStonewall section, a NE/SW-trending lineament may affect regional ground-water flow patterns. For example, ground water originating from Cactus and Gold Flats in the northeast may be forced to the surface and discharge at areas on, or adjacent to, the Sarcobatus Flat playa. Uncertainty also exists in the potential for ground-water flow through the Bullfrog Hills into the Amargosa Valley.

The Grapevine Canyon-Mesquite Flat section contains a major discharge area that includes Grapevine and Staininger Springs (at Scotty's Castle). Discharge at these sites appears to originate as ground water that has flowed from the northeast to the southwest past Sarcobatus Flat (fig. 10) (D'Agnese and others, 1997). The springs also may result from structural and topographic controls. The intersection of the small-permeability, NW/SE-trending Death Valley fault with an apparently large-permeability NE/SWtrending structural zone (Carr, 1984) may result in the truncation of the large-permeability zone causing ground water to discharge. Ground water that does not discharge in Grapevine Canyon continues past this discharge area to flow down the axis of Death Valley to discharge at Mesquite Flat. Additional ground water that may enter the flow system from Saline Valley is also interpreted to discharge at Mesquite Flat.

The Oriental Wash section includes a small spring area at Sand Spring in northern Death Valley. These comparatively low-temperature and smallvolume springs appear to be discharging locally derived ground water recharged on the dominantly granitic mountains to the north. Ground-water flow is apparently directed toward the springs along the axis of Oriental Wash, which is associated with a NE/SWtrending structural zone (Carr, 1984), and the 


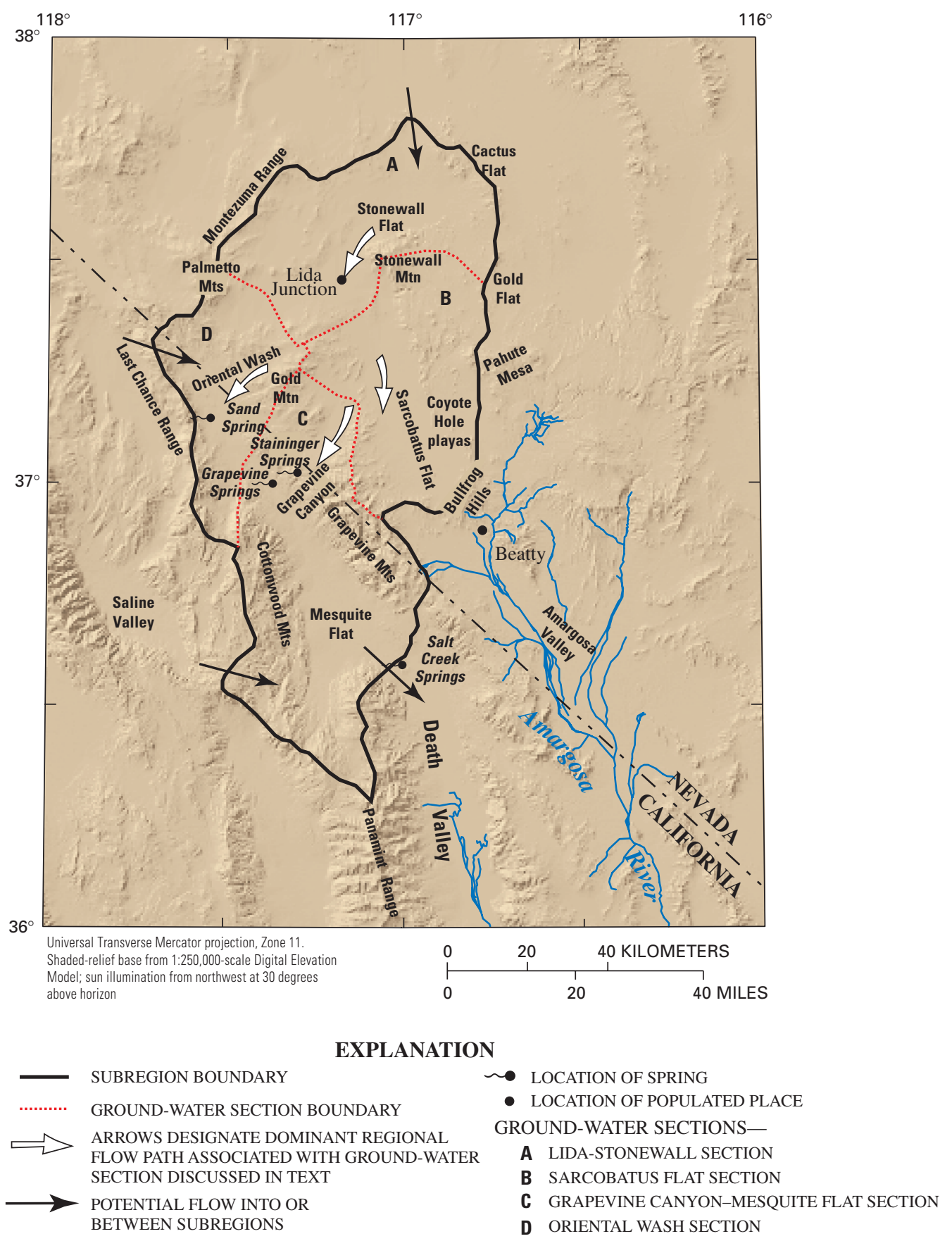

Figure 10. Northern Death Valley subregion.

discharges occur along the northern terminus of the Death Valley fault. Some ground water moving along this flow path may also bypass Sand Spring and flow down the axis of Death Valley toward Mesquite Flat. It is also inferred that ground water that potentially may enter the system as underflow from Eureka Valley may likewise flow down the axis of Death Valley toward Mesquite Flat (fig. 10).

\section{Central Death Valley Subregion}

In the Central Death Valley subregion, the dominant flow paths historically have been associated with major regional or subregional discharge areas. In this subregion, flow paths have traditionally been grouped into three ground-water basins, each containing several sections (fig. 11): Pahute Mesa-Oasis Valley ground-water basin, Ash Meadows ground-water 


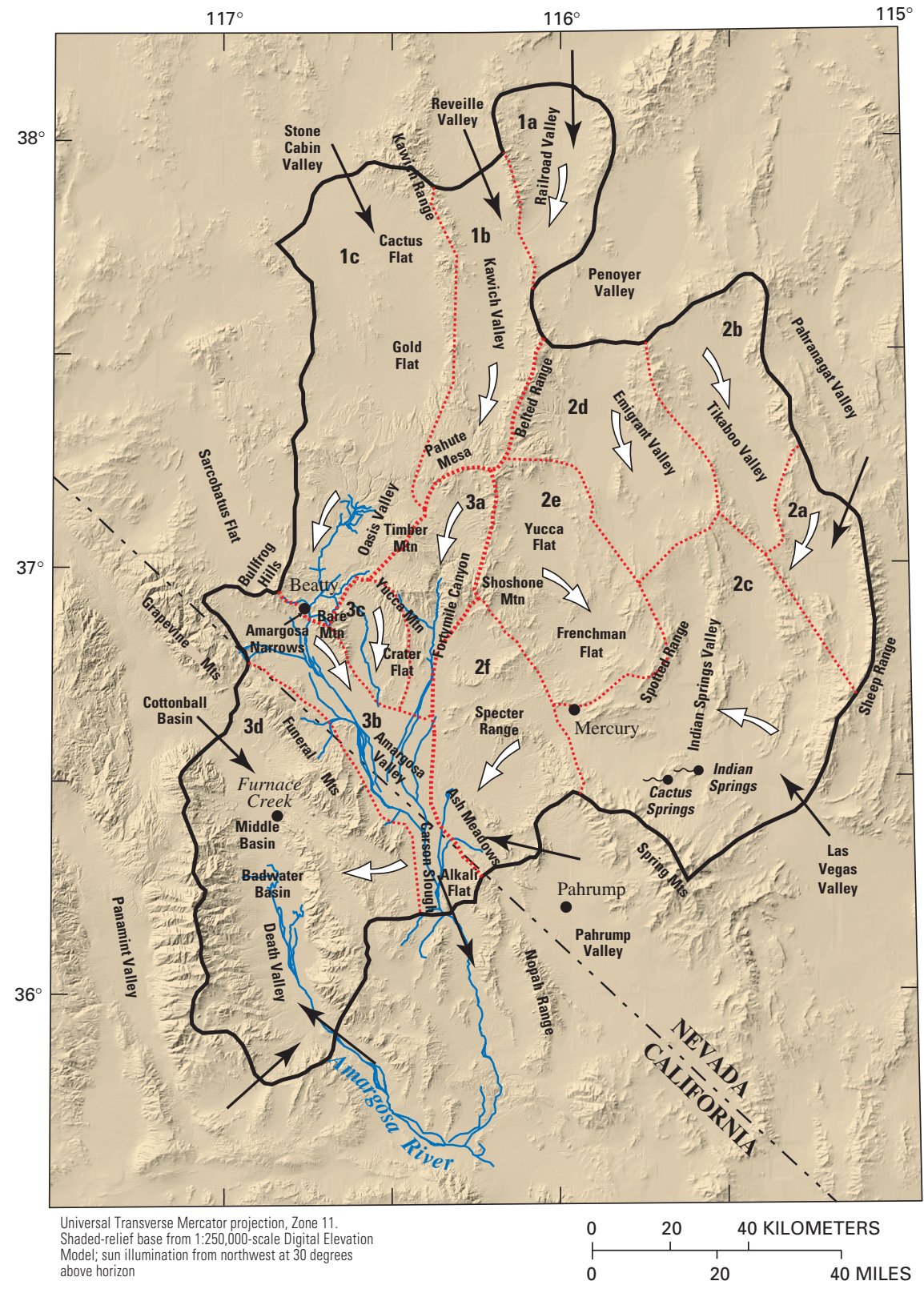

EXPLANATION

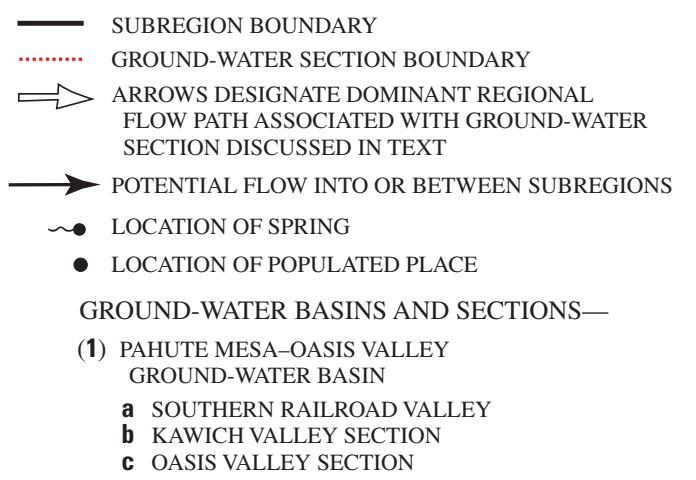

(2) ASH MEADOWS GROUND-WATER BASIN

a PAHRANAGAT SECTION

b TIKABOO VALLEY SECTION

c INDIAN SPRINGS SECTION

d EMIGRANT VALLEY SECTION

e YUCCA-FRENCHMAN FLAT SECTION

f SPECTER RANGE SECTION

(3) ALKALI FLAT-FURNACE CREEK GROUND-WATER BASIN

a FORTYMILE CANYON SECTION

b AMARGOSA RIVER SECTION

c CRATER FLAT SECTION

d FUNERAL MOUNTAINS SECTION

Figure 11. Central Death Valley subregion. 
basin, and Alkali Flat-Furnace Creek ground-water basin (D'Agnese and others, 1997).

\section{Pahute Mesa-Oasis Valley Ground-Water Basin}

Ground water in the Pahute Mesa-Oasis Valley basin is derived dominantly from infiltration in the Kawich and Belted Ranges and Pahute Mesa (D'Agnese and others, 1997). Additional recharge may occur as regional ground water flows across system boundaries from southern Railroad, Reveille, and Stone Cabin Valleys (\#1, \#2, and \#3 in fig. 7; fig. 11). Because the western boundary of this basin is poorly defined, ground water in the western part of the basin (parts of Cactus and Gold Flats) may flow toward the eastern part of Sarcobatus Flat. This ground-water basin has three dominant sections: the southern Railroad Valley section, the Kawich Valley section and the Oasis Valley section (fig. 11).

Ground water in the southern Railroad Valley section originates either as recharge on the flanking mountains or as underflow from northern Railroad Valley (D'Agnese and others, 1997). Ground water in the section dominantly flows south and southwest toward Kawich Valley (fig. 11).

Ground water in the Kawich Valley section may flow toward a potentiometric-surface trough located under western Pahute Mesa (Waddell and others, 1984). A possible regional fault or fracture zone has been described at this location (Blankennagel and Weir, 1973). Water flowing along this trough toward Oasis Valley is a primary feature of this section. At Oasis Valley, ground water is discharged by evapotranspiration and spring flow. Ground water that does not discharge within Oasis Valley flows through the subsurface at the Amargosa Narrows south of Beatty and into the Alkali Flat-Furnace Creek ground-water basin (Waddell, 1982) (fig. 11). Small amounts of ground water in Oasis Valley also may flow toward Crater Flat under Bare Mountain.

\section{Ash Meadows Ground-Water Basin}

The Ash Meadows ground-water basin is the largest basin in the Central Death Valley subregion (Waddell, 1982). Much of the ground water in this basin is derived from infiltration on the mountain ranges that surround the basin. Additional recharge may occur as regional ground water flows across system boundaries at Pahranagat Valley (Winograd and Thordarson, 1975) (\#9, fig. 7). This basin is subdivided into six sections (fig. 11): Pahranagat section, Tikaboo Valley section, Indian Springs section, Emigrant Valley section, Yucca-Frenchman Flat section, and Specter Range section.

Ground water recharged on the mountain areas of this ground-water basin travels mostly toward the center of the basin approximately located near the Spotted Range. Ground water in Tikaboo Valley, Emigrant Valley, and Yucca and Frenchman Flats is interpreted as flowing toward a potentiometric trough (D'Agnese and others, 1998). Regional and subregional ground water recharged on the Sheep Range and Spring Mountains also flows into this potentiometric trough from the south and east, thereby contributing to ground-water flow past Indian Springs Valley (fig. 11).

The potentiometric-surface trough may be a zone of high permeability associated with the Spotted Range-Mine Mountain structural zone (Carr, 1984; D'Agnese and others, 1998) and is believed to include numerous regional faults and fractures (Winograd and Thordarson, 1975). The trough is bounded on the south and southeast by the Las Vegas Valley shear zone (fig. 9). The shear zone may contain low-permeability material, possibly fault gouge (Winograd and Thordarson, 1975), causing discharge at Indian and Cactus Springs. The flow paths along the trough are directed through the Specter Range area until they encounter a NW/SE-trending fault at Ash Meadows. This fault causes much of the ground water to be discharged as spring flows and evapotranspiration (Winograd and Thordarson, 1975). Ground water that does not discharge at Ash Meadows flows into the Alkali Flat-Furnace Creek ground-water basin where it mixes with ground water moving along regional and subregional flow paths (fig. 11).

\section{Alkali Flat-Furnace Creek Ground-Water Basin}

In this basin, ground water is derived from infiltration on Pahute Mesa, Timber Mountain, Shoshone Mountain, and the Grapevine and Funeral Mountains. Additional recharge to this basin may occur as interbasinal ground-water flow across basin boundaries from Sarcobatus Flat, Oasis Valley, and Ash Meadows. The Alkali Flat-Furnace Creek ground-water basin is divided into four sections (fig. 11): Fortymile Canyon section, Amargosa River section, Crater Flat section, and Funeral Mountains section. 
Locally recharged ground water moves toward discharge areas in the southern parts of the basin. Dominant ground-water flow paths appear to mimic surface-water flow. The surface-water flow seems to be structurally controlled along the Amargosa River and Fortymile Wash and in Crater Flat (Grose and Smith, 1989). In the northwestern portions of the basin, subregional ground-water movement is dominantly lateral and downward toward regional flow paths (Czarnecki and Waddell, 1984; Sinton, 1987; and Kilroy, 1991). Near Yucca Mountain, however, gradients are dominantly upward into the volcanic units (Luckey and others, 1996). In the south-central portions of the basin, near the Nevada-California border (fig. 11), regional ground-water movement is dominantly upward from carbonate units into the subregional system and toward discharge areas along the Amargosa River, Carson Slough, and Alkali Flat (Czarnecki and Waddell, 1984; Czarnecki, 1990).

In the southern Amargosa Valley, regional ground-water movement is toward the southwest and south. This ground water may either flow through fractures in the southeastern end of the Funeral Mountains and discharge at Furnace Creek or flow southward and discharge at Alkali Flat (Czarnecki and Waddell, 1984; Czarnecki and Wilson, 1991). Once past the springs at Furnace Creek, the ground water flows toward the saltpan and is discharged either by stands of mesquite on the lower part of the Furnace Creek fan or by evaporation from the Death Valley saltpan. Additional ground water entering Death Valley as underflow from Panamint Valley may also discharge at the saltpan.

Ground water that moves along shallow flow paths, but does not discharge at the Amargosa River, Carson Slough, or Ash Meadows, moves southward toward Alkali Flat where it discharges as spring flow and evapotranspiration. Walker and Eakin (1963) estimated that approximately $1,700 \mathrm{~m}^{3} / \mathrm{d}$ of ground water flows past Alkali Flat into the southern Death Valley subregion.

\section{Southern Death Valley Subregion}

In general, ground water in the Southern Death Valley subregion is derived primarily from infiltration on the Spring Mountains and small inputs from the Nopah, Kingston, and Greenwater Ranges (fig. 12). Additional minor ground-water flow into this subregion may occur across the boundary from the Alkali Flat-Furnace Creek basin south of Alkali Flat, and farther south from Pilot Knob Valley (fig. 7). The subregion contains five sections (fig. 12): Pahrump Valley section, Shoshone-Tecopa section, California Valley section, Ibex Hills section, and Valjean Valley section.

Ground water recharged on the Spring Mountains moves toward Pahrump Valley. Historically, springs discharged at Manse and Bennett Springs along the base of the broad alluvial fans at the foot of the Spring Mountains. Pumping of ground water in the valley had caused these springs to cease flowing. More recently (late 1990's) Manse Spring has begun to flow again, perhaps due to changes in agricultural practices in the valley. Ground water in the Pahrump Valley section flows dominantly along subregional flow paths either to the west toward Stewart Valley and the northern end of Chicago Valley, or to the southwest toward California Valley. Because the Nopah Range is composed of low-permeability quartzite rocks in the subsurface (Grose, 1983), it is believed to cause a bifurcation in ground-water flow. Some of the ground water flowing toward the south and west is discharged at Stewart and Pahrump Valley playas. Some of this ground water may also discharge at the southern end of Ash Meadows at Big, Bole, and Last Chance springs (Winograd and Thordarson, 1975, p. 91; Peterman and Stuckless, 1992a, p. 70; Peterman and Stuckless, 1992b, p. 712). Ground-water flow that continues toward Chicago Valley, within the Shoshone-Tecopa section, mixes with ground water flowing from south of Alkali Flat and ultimately discharges as spring flows and ET in an area between the towns of Shoshone and Tecopa. In the California Valley section, ground water that flows south from Pahrump Valley discharges south of Tecopa at springs along the Amargosa River canyon in the Sperry Hills and at China Ranch (W.C. Steinkampf, U.S. Geological Survey and W.E. Werrell, National Park Service, written commun., 1996).

Ground water that does not discharge at the Shoshone-Tecopa area may continue flowing to the southwest into the Ibex Hills section to be discharged as spring flow and ET in the Saratoga Springs area, which includes adjacent areas of shallow ground water along the flood plain of the Amargosa River. Some additional ground water may enter the basin from Valjean and Shadow Valleys into California Valley and discharge at Saratoga Springs. A small amount of flow may continue north past Saratoga Springs to discharge at the Badwater Basin saltpan (fig. 12). Additional 


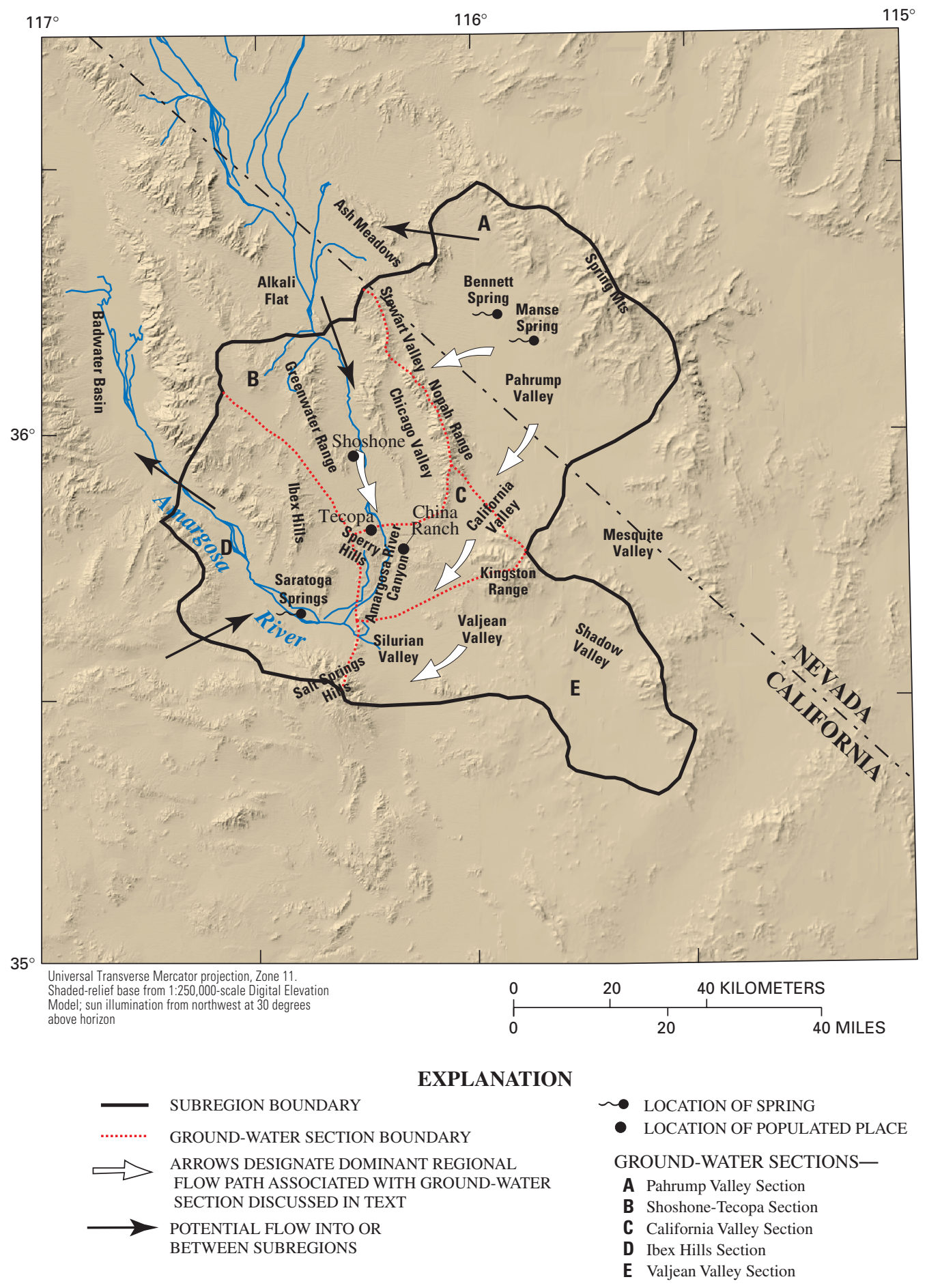

Figure 12. Southern Death Valley subregion. 
ground water entering Death Valley as underflow from Pilot Knob Valley may also discharge at the saltpan.

\section{Ground-Water System Budget Components}

Because inflow and outflow volumes are poorly defined for many areas in the Death Valley region, the water budget for the ground-water flow system is difficult to compute. The large size of this basin precludes the comprehensive and accurate assessment of all inflows to and outflows from the system. Despite this difficulty, several investigators have attempted to estimate water budgets for various parts of the flow system (Walker and Eakin, 1963; Rush, 1968; Malmberg and Eakin, 1962; Glancy, 1968; Malmberg, 1967; Hunt and others, 1966; Miller, 1977; Harrill, 1986; Waddell, 1982; Rice, 1984; Harrill and others, 1988; Dettinger, 1989; D'Agnese and others, 1997). These investigators used different boundaries to define the various basins in the flow system. Therefore, little if any of the data can be adequately compared.

Under natural, steady-state, predevelopment conditions, ground-water recharge occurs through infiltration of precipitation and spring flows and as underflows from adjacent basins, while ground-water discharge occurs through springs and ET. These processes account for the only ground-water system inflows and outflows. A discussion of how these ground-water flow system components were estimated for the simulation follows.

\section{Estimates of Ground-Water Discharge}

In arid regions such as the DVRFS, ET is a major process by which water is discharged from the ground-water flow system. Water stored within shallow unconfined aquifers is available for use by the local vegetation and at the water table is in contact with the atmosphere. Much of the water being evaporated or transpired from the DVRFS is constrained to local areas of ground-water discharge. The vast majority of the water evapotranspiring within these discharge areas originates as spring or seep flow or as diffuse upflow from underlying regional confined aquifers.

Evapotranspiration has been estimated for most of the major discharge areas of the DVRFS (Malmberg and Eakin, 1962; Walker and Eakin, 1963; Pistrang and Kunkel, 1964; Hunt and others, 1966; Malmberg, 1967; Cardinalli and others, 1968; Glancy, 1968; Rush, 1968; Winograd and Thordarson, 1975; Miller, 1977; Harrill, 1986; Czarnecki, 1997; D'Agnese and others, 1997; Laczniak and others, 1999; Laczniak and others, 2001). Most ET estimates were computed by multiplying the area of the land surface determined to be undergoing evapotranspiration by some average ET rate estimated for the area's soil and vegetation.

Discrepancies in these estimates typically result from differences in methods used to delineate areas or in methods used to estimate ET rates.

Many of the earlier estimates were developed as part of reconnaissance studies of the ground-water resource. Typically these studies were constrained to one or two discharge areas and relied on ET rates determined for vegetation from arid and semiarid areas outside the DVRFS. The most recent and comprehensive study of ET in the DVRFS is by Laczniak and others (2001). The primary focus of their study was to estimate, in a consistent manner, the average annual ET from the major areas of natural ground-water discharge within the Death Valley region shown in figure 13.

Laczniak and others (2001) identified and delineated ET areas in the DVRFS based on a classification of spectral satellite data. Each was classified into ET units that represent a unique combination of soil and vegetation conditions. As part of their study, these investigators estimated an average annual rate of ET for each identified ET unit within a discharge area. Estimates were computed from micrometeorological data collected within the local area over a multiyear period. To estimate the ground-water component of annual ET, they estimated a ground-water ET rate by subtracting that water assumed to originate from local precipitation. Their estimates of ground-water ET rates and spatial distributions of ET units were used in this study to develop an overall estimate of groundwater discharge from the DVRFS.

For discharge areas not evaluated in Laczniak and others (2001), ET distributions or average volumetric discharge from regional springs was developed from data available in published and in-progress studies. In Pahrump Valley, a map showing the distribution of phreatophytes in 1959-61 (Malmberg, 1967, pl. 3) was assumed to be a reasonable representation of the ET units prior to the start of ground-water development in the Pahrump Valley discharge area. Ground- 
water ET rates for these units were estimated from rates for similar ET units found in nearby areas given in Laczniak and others (2001). An ET-unit map developed from spectral imagery as part of an ongoing study of evapotranspiration in Death Valley (DeMeo and others, 1999) was used to delineate ET units in the Death Valley discharge area. Ground-water ET rates for these units were computed from micrometeorological data being collected in Death Valley as part of the ongoing study. In Penoyer Valley, the distribution and rate of ET used in the DVRFS model was taken directly from the UGTA regional ground-water flow model (U.S. Department of Energy, 1997) (fig. 13).

Four isolated areas where large volumes of ground-water discharge can be accounted for by spring flow are also simulated in the DVRFS. These include: Grapevine and Staininger Springs located near Scotty's Castle; Texas, Travertine, and Nevares Springs located at Furnace Creek Ranch; Indian and Cactus Springs located in Indian Springs, Clark County, Nevada; and Corn Creek Springs also at the north end of Las Vegas Valley (fig. 13).

Discharge volumes for these springs are taken from published reports. Discharge at Staininger Spring, the water supply for the Scotty's Castle area in Death Valley, has been reported in several publications (Ball, 1907; Waring, 1915; Waring, 1965; Rush, 1968; and Miller, 1977). Miller (1977) reports a measurement of 188 gallons per minute (gpm) $\left(1,025 \mathrm{~m}^{3} / \mathrm{d}\right)$ in 1971 and references three other measurements, $187 \mathrm{gpm}\left(1,019 \mathrm{~m}^{3} / \mathrm{d}\right)$ in $1924,180 \mathrm{gpm}\left(981 \mathrm{~m}^{3} / \mathrm{d}\right)$ in 1958 , and about $200 \mathrm{gpm}\left(1,090 \mathrm{~m}^{3} / \mathrm{d}\right)$ in the spring of 1967 as reported by Rush (1968). Ball (1907) reports approximately $600,000 \mathrm{gal} / \mathrm{d}\left(417 \mathrm{gpm}, 2,271 \mathrm{~m}^{3} / \mathrm{d}\right)$. Waring (1915) reports a discharge of $10 \mathrm{gpm}(54$ $\mathrm{m}^{3} / \mathrm{d}$ ) that was estimated or reported. Waring (1965) reports a discharge of $30 \mathrm{gpm}\left(163 \mathrm{~m}^{3} / \mathrm{d}\right)$. Mendenhall (1909) mentions the spring has an unlimited supply of good water but does not report a discharge. The actual measurements reported by Miller (1977) and Rush (1968) are probably the best to estimate an average discharge. The mean of the four measurements $[(188+187+180+200) / 4=188.75]$ is approximately $190 \mathrm{gpm}\left(1,035 \mathrm{~m}^{3} / \mathrm{d}\right)$.

Discharge at Grapevine Springs has only been measured by Miller (1977). Miller reported an aggregate discharge of $450 \mathrm{gpm}\left(2,450 \mathrm{~m}^{3} / \mathrm{d}\right)$ for the dozen or more springs and seeps. Miller also included evapotranspiration from 150 acres of phreatophytes in the discharge. Ball (1907) and Mendenhall (1909) mention the spring by name but do not report a discharge. Rush (1968) estimates the spring discharge of $20 \mathrm{gpm}\left(109 \mathrm{~m}^{3} / \mathrm{d}\right)$ by guessing. Perhaps the best estimate for discharge is presented by Miller, $450 \mathrm{gpm}\left(2,450 \mathrm{~m}^{3} / \mathrm{d}\right)$, and that value is used in the DVRFS simulation.

Discharge at Texas Spring has changed since the spring was improved by tunneling into the spring area. Waring (1915) lists a discharge of $25 \mathrm{gpm}$ $\left(136 \mathrm{~m}^{3} / \mathrm{d}\right)$. Pistrang and Kunkel (1964) report a National Park Service estimate of $0.28 \mathrm{ft}^{3} / \mathrm{s}$ $\left(685 \mathrm{~m}^{3} / \mathrm{d}\right)$ in 1926 . The tunnel was constructed between 1926 and 1941. Pistrang and Kunkel report a National Park Service discharge estimate of $0.38 \mathrm{ft}^{3} / \mathrm{s}$ $\left(930 \mathrm{~m}^{3} / \mathrm{d}\right)$ in 1941 . Pistrang and Kunkel report numerous discharges from 1956 to 1963 measured by the USGS with an 18-inch rectangular weir. The 1956-63 discharges generally ranged from 0.47 to $0.50 \mathrm{ft}^{3} / \mathrm{s}\left(1,150\right.$ to $\left.1,223 \mathrm{~m}^{3} / \mathrm{d}\right)$. Miller (1977) reports a discharge of $210 \mathrm{gpm}\left(1,145 \mathrm{~m}^{3} / \mathrm{d}\right)$ on December 8 , 1976. Discharges for 1989-92 (LaCamera and Westenburg, 1994), 1993 (Hale and Westenburg, 1995), 1994 (Westenburg and LaCamera, 1996), 1995 (LaCamera and others, 1996), 1996 (LaCamera and Locke, 1997) were measured by the National Park Service with a flume and by the USGS with a current meter. Measurements for 1990-92 were revised (LaCamera and Locke, 1997). All of these measurements are effectively within 15 percent of $1,220 \mathrm{~m}^{3} / \mathrm{d}$ and that value is used in the DVRFS simulation.

Pistrang and Kunkel (1964) report on Travertine Springs during the period 1956-64. Data collected by the USGS ranged from 1.68 to $1.94 \mathrm{ft}^{3} / \mathrm{s}(4,111$ to $\left.4,747 \mathrm{~m}^{3} / \mathrm{d}\right)$. Miller (1977) attributed short-term fluctuations in spring discharge to the condition and efficiency of the collection system and to the variation in ET losses in the collector area. Miller reports a long-term discharge of $850 \mathrm{gpm}\left(4,633 \mathrm{~m}^{3} / \mathrm{d}\right)$ during the period 1956-72, with no apparent change in longterm trend. Miller reports only a flow of $700 \mathrm{gpm}$ $\left(3,815 \mathrm{~m}^{3} / \mathrm{d}\right)$ from an aggregate of springs for January 6, 1977. Pistrang and Kunkel data are for 10 springs, while Miller's 1977 measurement is for 3 springs. No explanation is given for the change in the number of springs. Miller's 1977 measurement cannot be directly compared to Pistrang and Kunkel's data or to Miller's long-term average. All of Pistrang and Kunkel's data fall within 10 percent of Miller's long-term average except for the March 6, 1958, measurement. One month later the spring was cleaned out and was within 


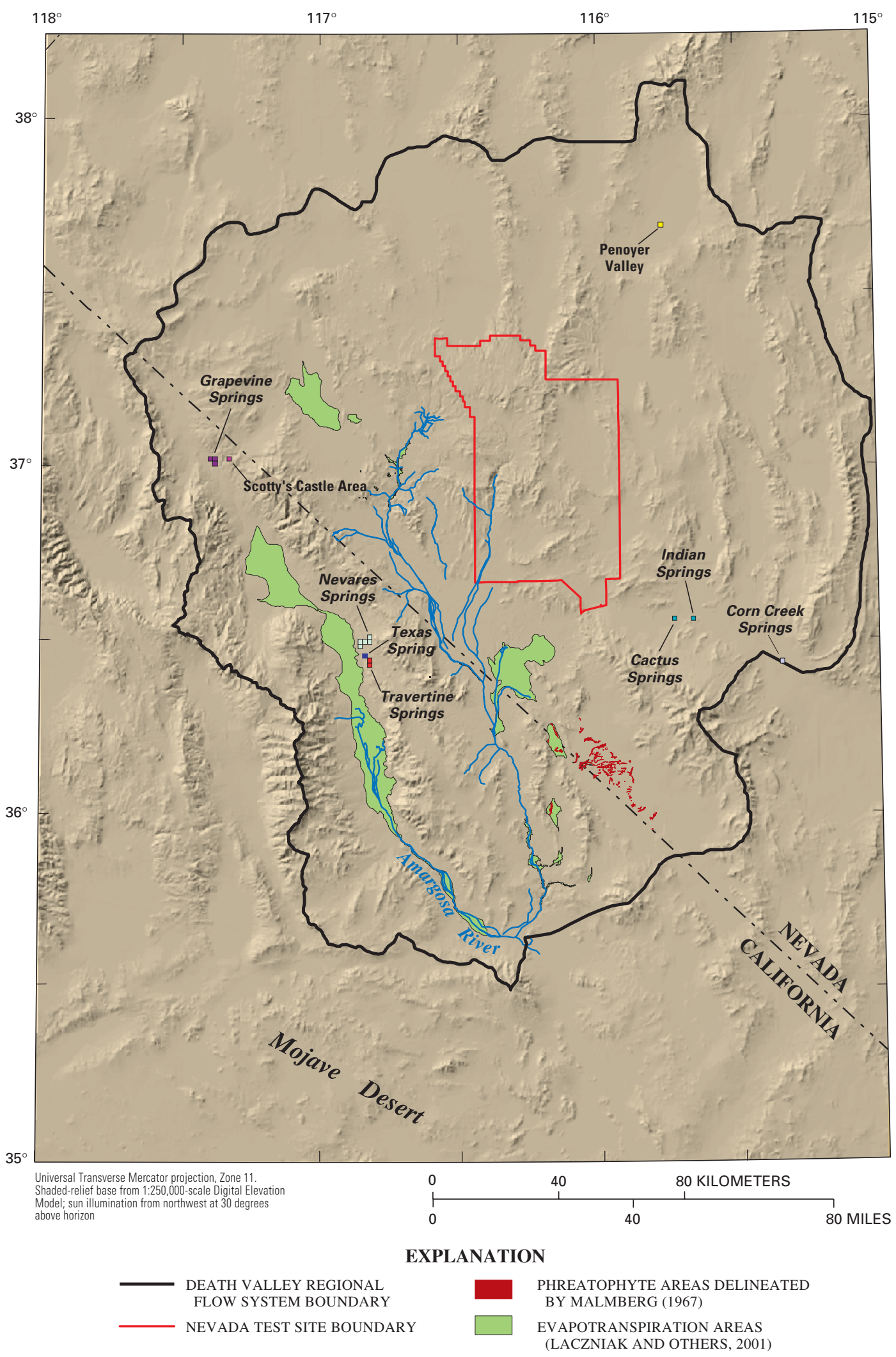

Figure 13. Ground-water discharge areas in the Death Valley regional flow system. 
10 percent of the average discharge. The low discharge on March 6, 1958, can probably be neglected. Miller's long-term average $850 \mathrm{gpm}\left(4,633 \mathrm{~m}^{3} / \mathrm{d}\right)$ is probably a good estimate of average discharge.

Pistrang and Kunkel (1964) report on the Nevares Spring discharge during 1951 and 1956-57. Average discharge during 1956-57 was $0.6 \mathrm{ft}^{3} / \mathrm{s}$ $\left(1,470 \mathrm{~m}^{3} / \mathrm{d}\right)$ for the main spring area. Discharge at the remaining Nevares Springs areas totaled $0.12 \mathrm{ft}^{3} / \mathrm{s}$ $\left(290 \mathrm{~m}^{3} / \mathrm{d}\right)$. Hunt and others (1966) report the combined discharge of five points collected by the USGS. The discharge was $0.73 \mathrm{ft}^{3} / \mathrm{s}\left(1,790 \mathrm{~m}^{3} / \mathrm{d}\right)$ in 1951 and $0.72 \mathrm{ft}^{3} / \mathrm{s}\left(1,760 \mathrm{~m}^{3} / \mathrm{d}\right)$ in 1957 . Miller (1977) reports a combined discharge of $260 \mathrm{gpm}$ $\left(1,420 \mathrm{~m}^{3} / \mathrm{d}\right)$ for Nevares Spring and a nearby unnamed spring. Miller's discharge is comparable to Pistrang and Kunkel's and is within 10 percent of the 1956-57 average of Pistrang and Kunkel. The discharge value $0.77 \mathrm{ft}^{3} / \mathrm{s}\left(1,884 \mathrm{~m}^{3} / \mathrm{d}\right)$ is probably the best discharge for all the combined Nevares Springs and is used in the DVRFS simulation.

Carpenter (1915) was the first to estimate discharge at Indian and Cactus Springs. He reports a discharge of $0.91 \mathrm{ft}^{3} / \mathrm{s}\left(2,230 \mathrm{~m}^{3} / \mathrm{d}\right)$ on December 15 , 1912. Maxey and Jameson (1948) estimated 400 gpm $\left(2,180 \mathrm{~m}^{3} / \mathrm{d}\right)$, Malmberg (1967) estimated 700 acrefeet per year (acre-ft/yr) $\left(2,365 \mathrm{~m}^{3} / \mathrm{d}\right)$, and Rush (1970) estimated 500 acre-ft/yr $\left(1,690 \mathrm{~m}^{3} / \mathrm{d}\right)$. The discharge estimates of Maxey and Jameson and Malmberg are within 10 percent of Carpenter's discharge. Rush's estimate appears to be over 20 percent underestimated with respect to the 1912 measurement or it represents a decline in discharge due to other groundwater withdrawals in the Indian Springs area. Rush (1970) has no discussion on the subject; he just reports the estimate. A good average estimate for Indian and Cactus Springs discharge used in the DVRFS simulation is $2,240 \mathrm{~m}^{3} / \mathrm{d}$.

Carpenter (1915) also has the first reported discharge for Corn Creek Spring; he reports a discharge of $0.2 \mathrm{ft}^{3} / \mathrm{s}\left(490 \mathrm{~m}^{3} / \mathrm{d}\right)$ on December 8, 1912 . Malmberg (1965) reports yearly discharge values of $240 \mathrm{acre}-\mathrm{ft} / \mathrm{yr}\left(811 \mathrm{~m}^{3} / \mathrm{d}\right)$ for 1946 and $200 \mathrm{acre}-\mathrm{ft} / \mathrm{yr}$ $\left(676 \mathrm{~m}^{3} / \mathrm{d}\right)$ for each year from 1947 to 1955 . From 1985-94 and 1997, daily discharges are reported in the USGS annual Water Resources Data report for Nevada (Pupacko and others, 1988; Pupacko and others, 1989a; Pupacko and others, 1989b; Pupacko and others, 1990; Bostic and others, 1991; Garcia and others, 1992; Hess and others, 1993; Emett and others, 1994; Clary and others, 1995; and Bonner and others,
1998). Malmberg's discharge estimate of $676 \mathrm{~m}^{3} / \mathrm{d}$ for 1947-55 appears to be a good estimate. The majority of the 1985-94 and 1997 discharge data are within 15 percent of this estimate. Carpenter's 1912 discharge is low compared to Malmberg's estimate. There is no supporting information to evaluate the 1912 data and compare it to the later data. The 1985-94 and 1997 discharge data show some variation with time but generally are within 15 percent of Malmberg's discharge. An average estimated discharge of $676 \mathrm{~m}^{3} / \mathrm{d}$ is used in the DVRFS simulation.

A summary of discharge observation descriptions and observed ground-water discharge rates in the DVRFS are presented in table 3 . Figure 13 shows all ground-water discharge areas simulated in the DVRFS.

\section{Estimates of Recharge}

The major source of recharge to the regional ground-water flow system is from precipitation on the higher mountains within the region. The regional flow system is also recharged by some interbasin flow from outside of the DVRFS. Some recharge also results from recycled irrigation and domestic waters as well as seepage of spring discharge back into the groundwater system (Rice, 1984). These recycled components are considered to be small compared to regional infiltration and interbasin flux volumes and are neglected (Waddell, 1982, p. 14).

Empirical, water-balance, and distributedparameter methods have been used to characterize the location and amount of recharge in the Death Valley region. Each method attempts to characterize the complex array of factors controlling recharge; each has limitations.

An empirical precipitation-recharge relation was developed by Maxey and Eakin (1950) from water mass-balance estimates for basins in southern and eastern Nevada. They suggest that the annual precipitation amount and the percentage of precipitation that becomes ground-water recharge increases with increasing altitude. Depending on the valley, Maxey and Eakin (1950) assumed that no recharge occurs where mean annual precipitation is less than about 200 millimeter $(\mathrm{mm})$ or altitude is lower than $1,524 \mathrm{~m}$. Above $1,524 \mathrm{~m}$ in altitude, they assigned an increasing percentage of precipitation that was assumed to become recharge to a ranked series of 305-m altitude intervals (table 4). 
Table 3. Description of flow observations with observed discharge and coefficient of variation used in the calibrated model

\begin{tabular}{|c|c|c|c|}
\hline Observation description & $\begin{array}{l}\text { Observation } \\
\text { name }\end{array}$ & $\begin{array}{c}\text { Observed discharge, } \\
\text { in cubic meters } \\
\text { per day }\end{array}$ & $\begin{array}{c}\text { Coefficient of } \\
\text { variation }\end{array}$ \\
\hline Ash Meadows, Amargosa Flat & G-AM-AMFLT & 6,019 & ${ }^{\mathrm{I}} 0.32$ \\
\hline Ash Meadows, Carson Slough & G-AM-CARSL & 498 & 0.50 \\
\hline Ash Meadows, central area & G-AM-CENTR & 21,444 & ${ }^{1} 0.15$ \\
\hline Ash Meadows, upper drainage & G-AM-UPDRN & 3,219 & 0.15 \\
\hline Ash Meadows, northern area & G-AM-NORTH & 19,499 & ${ }^{1} 0.14$ \\
\hline Ash Meadows, southern area & G-AM-SOUTH & 10,085 & ${ }^{1} 0.23$ \\
\hline Chicago Valley & G-CHICAGOV & 1,452 & ${ }^{1} 0.36$ \\
\hline Corn Creek Springs & G-CORNCREK & 676 & 1.00 \\
\hline Death Valley, Badwater basin area & G-DV-BADWT & 5,019 & 0.28 \\
\hline Death Valley, Confidence Hills area & G-DV-CONFI & 6,651 & 0.28 \\
\hline Death Valley, Cottonball basin area & G-DV-COTTN & 3,547 & 0.28 \\
\hline Death Valley, Furnace Creek alluvial fan & G-DV-FRNFN & 10,185 & 0.28 \\
\hline Death Valley, Mesquite Flat area & G-DV-MESQU & 29,075 & 0.28 \\
\hline Death Valley, Middle basin & G-DV-MIDDL & 2,587 & 0.28 \\
\hline Death Valley, Mormon Point area & G-DV-MORMN & 7,225 & 0.28 \\
\hline Death Valley, Nevares Springs & G-DV-NEVAR & 1,884 & 0.15 \\
\hline Death Valley, Saratoga Springs area & G-DV-SARAT & 6,535 & 0.28 \\
\hline Death Valley, Texas Spring & G-DV-TEXAS & 1,220 & 0.15 \\
\hline Death Valley, Travertine Springs & G-DV-TRVRT & 4,633 & 0.10 \\
\hline Death Valley, western alluvial fans & G-DV-WESTF & 13,637 & 0.28 \\
\hline Franklin Well area & G-FRANKWEL & 1,182 & 0.50 \\
\hline Franklin Lake, eastern area & G-FRNKLK-E & 411 & 1.00 \\
\hline Franklin Lake, northern area & G-FRNKLK-N & 2,254 & 1.00 \\
\hline Franklin Lake, southern area & G-FRNKLK-S & 711 & 1.00 \\
\hline Grapevine Springs, Scotty's Castle area & G-GRAPE-SC & 1,035 & 0.50 \\
\hline Grapevine Springs, spring area & G-GRAPE-SP & 2,450 & 0.20 \\
\hline Indian Springs and Cactus Springs & G-INDIANSP & 2,240 & 0.10 \\
\hline Oasis Valley, Beatty area & G-OV-BEATY & 2,774 & ${ }^{1} 0.13$ \\
\hline Oasis Valley, Coffer's Ranch area & G-OV-COFFR & 5,343 & ${ }^{1} 0.19$ \\
\hline Oasis Valley, middle Oasis Valley area & G-OV-OASIS & 3,157 & ${ }^{1} 0.10$ \\
\hline Oasis Valley, Springdale area & G-OV-SPRDL & 8,113 & ${ }^{1} 0.10$ \\
\hline Pahrump Valley, Bennett Spring area & G-PAH-BENT & 16,753 & 0.50 \\
\hline Pahrump Valley, Manse Spring area & G-PAH-MANS & 5,375 & 0.50 \\
\hline Penoyer Valley area & G-PENOYERV & 12,833 & 0.50 \\
\hline Sarcobatus Flat, Coyote Hills area & G-SARCO-CH & 1,503 & ${ }^{1} 0.55$ \\
\hline Sarcobatus Flat, northeastern area & G-SARCO-NE & 30,421 & ${ }^{1} 0.46$ \\
\hline Sarcobatus Flat, southwestern area & G-SARCO-SW & 11,960 & ${ }^{1} 0.53$ \\
\hline Shoshone basin, northern area & G-SHOSH-N & 2,259 & ${ }^{1} 0.16$ \\
\hline Shoshone basin, southern area & G-SHOSH-S & 4,831 & ${ }^{1} 0.15$ \\
\hline Stewart Valley, predominantly playa area & G-STEWRT-P & 995 & 0.16 \\
\hline Stewart Valley, predominantly vegetation area & G-STEWRT-V & 2,381 & ${ }^{1} 0.56$ \\
\hline Tecopa basin, Amargosa Canyon area & G-TC-AMCAN & 3,394 & ${ }^{1} 0.13$ \\
\hline Tecopa basin, China Ranch area & G-TC-CHRNC & 1,784 & 0.50 \\
\hline Tecopa basin, Resting Spring area & G-TC-RESTS & 2,537 & ${ }^{1} 0.16$ \\
\hline Tecopa basin, Sperry Hills area & G-TC-SPERY & 1,341 & 0.50 \\
\hline Tecopa basin, central area & G-TC-TECOP & 12,221 & ${ }^{1} 0.12$ \\
\hline
\end{tabular}


Table 4. Area-altitude classes modified from Maxey and Eakin (1950)

[ $\mathrm{m}$, meters; datum is sea level; $>$, greater than; $<$, less than]

\begin{tabular}{cc}
\hline $\begin{array}{c}\text { Area-altitude } \\
\text { class }\end{array}$ & $\begin{array}{c}\text { Precipitation } \\
\text { percentage that } \\
\text { becomes recharge }\end{array}$ \\
\hline$>2,439 \mathrm{~m}$ & 25 \\
$2,134-2,439 \mathrm{~m}$ & 15 \\
$1,829-2,134 \mathrm{~m}$ & 7 \\
$1,524-1,829 \mathrm{~m}$ & 2 \\
$<1,524 \mathrm{~m}$ & 0 \\
\hline
\end{tabular}

Other investigators working in the Great Basin developed similar area-altitude relations for their studies (Walker and Eakin, 1963; Miller, 1977; Malmberg and Eakin, 1962; Malmberg, 1967; Winograd and Thordarson, 1975; Harrill, 1986). Each investigator noted that the method was completely empirical and ignored differences in lithology, soils, climate, vegetation, and topographic factors such as exposure, aspect, and slope.

Rice (1984) developed a relatively detailed recharge calculation as part of a regional modeling study. Rice employed a water-balance method that utilized average annual precipitation distributions derived from Quiring's (1965) regressions and potential ET estimates developed from empirical methods. These computations showed that recharge occurs if the altitude is greater than $1,675 \mathrm{~m}$ and the annual precipitation is greater than $254 \mathrm{~mm}$. Because these two criteria meet the plant requirements of pinyon pine and juniper, Rice placed the area of recharge to coincide with that plant zone and plant zones of higher altitude and moisture. More recent investigations by West (1989) have placed the lower altitude limits of regional recharge at the Mixed Shrub-Transition Zone where blackbrush flourishes. West noted that these communities represent the altitudinal zone at which winter recharge of soil moisture is normally balanced by summer ET loss. Therefore, in wet years some regional recharge may occur in these areas.

Recent investigators have attempted to refine the Maxey-Eakin method by adapting it to make it more sensitive to the physical land-surface factors affecting recharge. For the YMP regional model, D'Agnese and others (1997) used comparative hydrogeologic data sets to enhance the Maxey-Eakin method. Several recharge indicators were identified, including (1) elevation, (2) slope aspect, (3) rock type, and (4) vegetation. These data sets were classified into four maps describing recharge potential on a five-point scale, where 1 represents low recharge potential and 5 represents high recharge potential. The four recharge-potential maps were then grouped to develop a final map containing six classes: high, high-moderate, moderate, moderate-low, low, and no recharge potential. The areas most likely to have high recharge potential were those that possessed favorable conditions for all four recharge indicators.

The six recharge-potential classes were similar to those used in the Maxey-Eakin method in that they were used in the ground-water flow model to represent a percentage of average annual precipitation that is recharged. However, during calibration of the YMP model, parameter sensitivities indicated that perhaps only four zones representing high, moderate, low, and no recharge potential could be estimated given the model constraints supplied by hydraulic head and spring flow observations. In the final YMP regional model, recharge occurred in zones of 0 percent, 1 percent, 3 percent, and 23 percent average annual precipitation.

For the UGTA regional model, the amount of recharge was calculated using a modification of the Maxey-Eakin method. In and near the NTS, the recharge was modified to account for runoff and recharge below stream channels and in distributary fan deposits. This primarily resulted in simulated recharge beneath Fortymile Canyon and Fortymile Wash. The Maxey-Eakin coefficients and ranges then were adjusted to produce a recharge rate equal to the algebraic sum of the other model fluxes, while producing recharge in lower elevation areas such as Shoshone Mountain and the Bullfrog Hills.

For this investigation, a distributed-parameter, process-based, numerical, net infiltration model developed by Hevesi and others (2002) is used. Their numerical model, INFIL, was developed using components of the mass-balance equation. The numerical model is quasi-three-dimensional and uses quasimass-balance processes, real or stochastically simulated precipitation, parameters describing the physical setting, and hydrologic properties of the Death Valley region to approximate actual conditions. The model is calibrated by matching simulated daily mean streamdischarge rates to the measured daily mean discharge resulting from episodic runoff events at calibration basins. In addition to measured stream discharge, the model was calibrated using volumetric water content data from neutron boreholes that were used to calcu- 
late flux. The model results in a calculated distribution of net infiltration for the region. In this manner the results of the model substantiate a conceptual model of net infiltration that is based on the physical setting and hydrologic properties of the region. The distribution of regional net infiltration can be used to represent regional ground-water recharge by assuming that water that is simulated to infiltrate past the "root zone" ultimately becomes ground-water recharge (fig. 14).

Net infiltration for the DVRFS based on the INFIL model developed by Hevesi and others (2002), however, suggests that estimated recharge in the DVRFS exceeds the estimated ground-water discharge for the basin by almost a factor of four. Limitations of the net infiltration model that may contribute to this overestimation include:

1. Processes between the root zone and the water table are not taken into account,

2. Defined bedrock permeability could be unrealistically large,

3. ET was underestimated in upland areas with thin soil,

4. Precipitation record for 1980-95 used in the model was higher than the long-term average,

5. Rainfall extrapolation algorithm overestimated rainfall in many areas,

6. Soil moisture properties were overly generalized,

7. Errors in saturated and unsaturated hydraulicconductivity estimates may have affected certain soil types and climate conditions, and

8. All natural-system processes and conditions, many of which act to reduce infiltration, could not be simulated with the simplifications in the model.

The net infiltration model was sensitive to simulated soil and rock properties, precipitation rates, and simplifications. These model limitations tended to overestimate net infiltration. Ultimately, rates of net infiltration could be overestimated because significant quantities of water could be impeded or redistributed by relatively unknown processes in the unsaturated zone before crossing the water table; therefore, some means of evaluating the potential effects of this INFIL model simplification must be developed during the DVRFS model simulation.

\section{NUMERICAL MODEL OF REGIONAL GROUND-WATER FLOW}

Development of a numerical model allows for a more detailed analysis of the movement of ground water through the numerous hydrogeologic units that constitute the shallow, local, and subregional ground- water-flow system components and the dominant regional flow system controlled by the carbonate aquifer. The resulting DVRFS model is necessarily large and complex. Calibration of this model by strictly trial-and-error methods was judged to be both ineffective and inefficient; therefore, nonlinear regression methods are used to estimate parameter values that produce the best fit to observed heads and flows. Related methods are used to evaluate model results.

\section{Numerical Modeling Difficulties, Simplifi- cations, and Assumptions}

Previous studies by Prudic and others (1993) and Waddell (1982) showed that it is difficult to utilize computer models to effectively describe ground-water flow in an area as geographically large and geologically complicated as the Death Valley region. Prudic and others (1993) reiterated that many arguments can be invoked concerning the validity of the assumptions and hydrologic values used in simulating groundwater flow when such complex geology and hydrology are involved.

Inevitably, simplifications and assumptions must be used to adapt the complex conceptual model for numerical simulation. The assumptions and simplifications used to develop the DVRFS model include the following:

1. Ground water in the region flows through fractures and solution openings of consolidated rocks, as well as in porous valley-fill alluvium. However, fracture-flow simulation is impractical at a regional scale; therefore, a porous medium simulation is used. This assumption is probably reasonable because the (1,500-m cell size) model grid used to simulate regional flow results in the averaging of hydraulic properties over $2.25-\mathrm{km}^{2}$ areas. Despite the seemingly large size of the model grid, one grid cell is quite small when compared to the overall area of $69,840 \mathrm{~km}^{2}$. Some of the factors considered when determining an appropriate model-cell size were computational efficiency, appropriately representing the available data, and ability to effectively simulate regional-scale ground-water flow.

2 . The model simulation assumes steady-state conditions prior to development, in which estimates of recharge (calculated from data gathered between 1980 and 1995) equal estimates of natural discharge prior to ground-water development. 


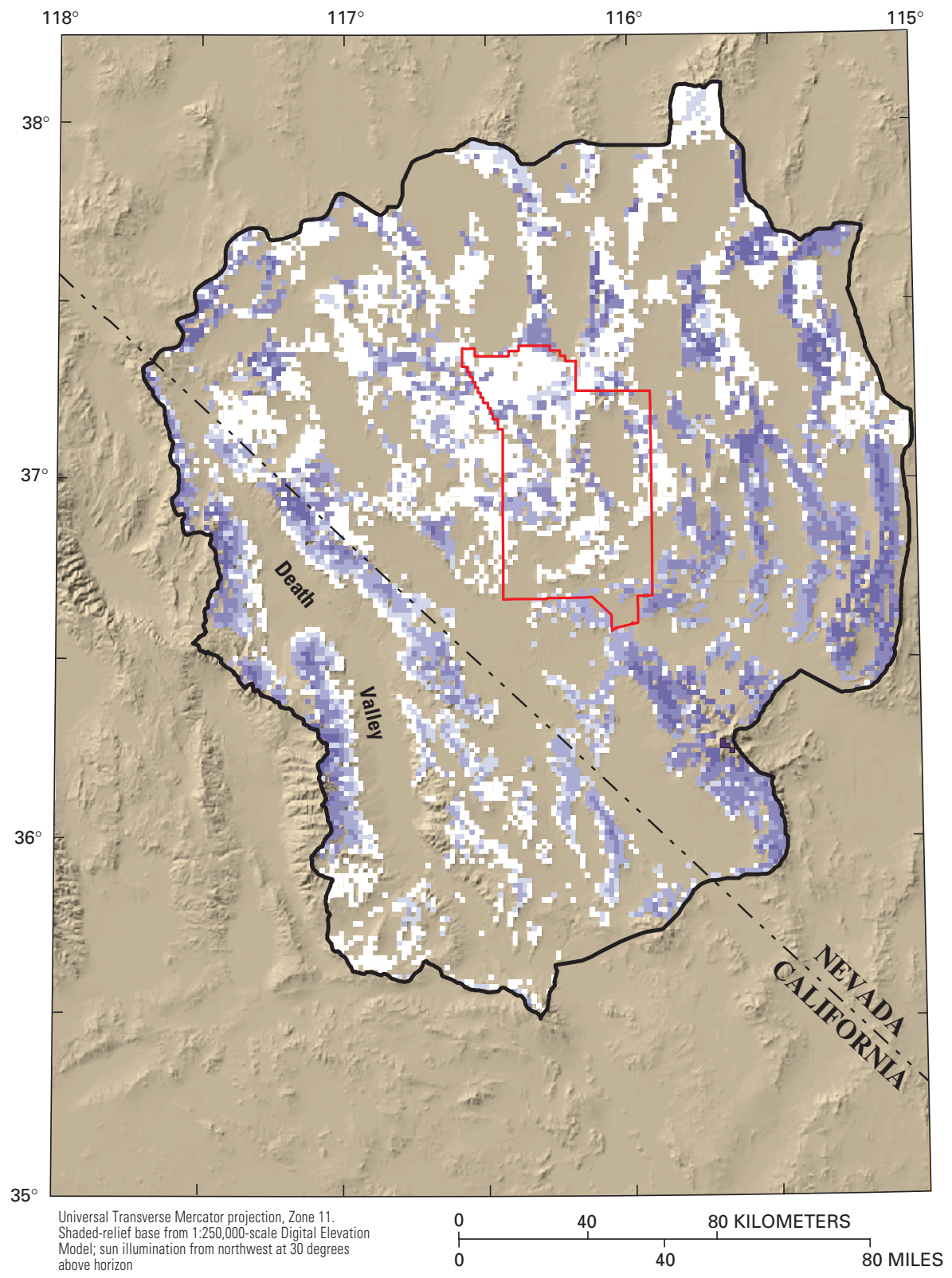

\section{EXPLANATION}

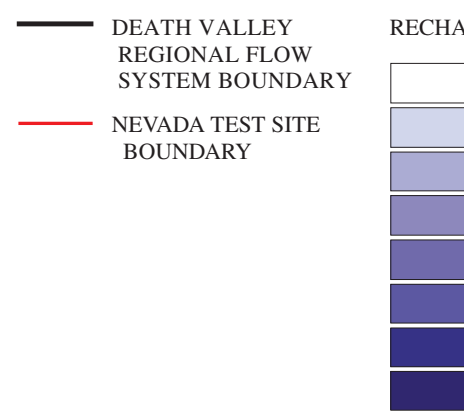

RECHARGE GRID (millimeter per year)

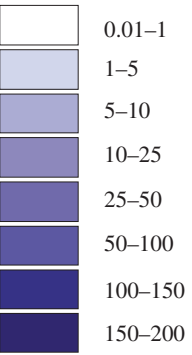

Figure 14. Net infiltration for the Death Valley regional flow system using INFIL (Hevesi and others, 2002). 
That is, the model does not include ground-water withdrawals. Whether current recharge equals natural discharge is unknown. Three conditions exist, however, that may violate this assumption. First, the regional flow system still may be undergoing a drying-out sequence following a wetter climate cycle related to the late Pleistocene (Prudic and others, 1993). As a result, current ground-water levels and discharge rates may not be in equilibrium with present-day recharge and interbasinal flux rates. Second, the flow system may experience seasonal fluctuations that are reflected in the target data but not accounted for in the simulation. A resulting annual average condition is simulated. Third, hydraulic-head, spring-flow, and other data used in model calibration were collected over an interval of many years, and these data are affected by seasonal and yearly changes to the ground-water flow system. While data analysis was undertaken to evaluate hydraulic-head observations for many of these conditions, in many cases insufficient data were available to make a reasonable conclusion.

3. Horizontal isotropy within each model cell is used. This assumption is reasonable for cells corresponding to basin fill, but may be unreasonable for cells corresponding to consolidated rocks. Where flow is through fractures, the fractures may have a preferred orientation that could produce a greater hydraulic conductivity in one direction. While the model is capable of simulating a different horizontal anisotropy on a cellby-cell basis, it can do so only along the defined row-column orientation. Also, because the region contains numerous regional fracture patterns, it was concluded that no single orientation was dominant over the entire model domain.

\section{Numerical Model Selection}

The numerical modeling code used in this study is MODFLOW-2000 (Harbaugh and others, 2000; Hill and others, 2000). As documented by Harbaugh and others (2000), MODFLOW-2000 is a version of the U.S. Geological Survey 3D, finite-difference modular ground-water flow modeling code, MODFLOW (McDonald and Harbaugh, 1988; Hill, 1992) in which nonlinear regression may be used to estimate flow- model parameters that result in the best fit to measured hydraulic heads and flows.

MODFLOW-2000 is a block-centered finite-

difference code that views a 3D flow system as a sequence of layers of porous material organized in a horizontal grid or array. The horizontal grid is generated by specifying array dimensions in the $\mathrm{x}$ and $\mathrm{y}$ directions. In the DVRFS model, model layers are defined as being confined, so that layer thickness is constant. Although the top layer in the simulated flow system is clearly unconfined, defining its thickness from an estimated potentiometric-surface map and representing it as confined produces a good approximate thickness and is much more efficient numerically. Also, for a steady-state simulation, model layers that are simulated as confined closely approximate that of an unconfined layer.

\section{Nonlinear Regression Objective Function}

Nonlinear regression estimates parameter values by finding the values that minimize the weighted sum of squared residuals objective function, $S(\underline{b})$, which is calculated as:

$$
S(\underline{b})=\left(\underline{y-y^{\prime}}\right)^{T} \underline{W}\left(\underline{y-y^{\prime}}\right)
$$

where

$\underline{b}$ is an $n p \times 1$ vector containing parameter values; $n p$ is the number of parameters estimated by regression;

$y$ and $y^{\prime}$ are $n \times 1$ vectors with elements equal to observed and simulated (using $\underline{b}$ ) values respectively (for the DVRFS model, the observed and simulated quantities are hydraulic heads and ground-water discharge);

$y-y^{\prime}$ is a vector of residuals, defined as the observed minus simulated values;

$n$ is the number of measured and simulated hydraulic heads and flows;

$\underline{W}$ is an $n \times n$ weight matrix; and

$T$ superscripted indicates the transpose of the vector.

For the DVRFS model, the weight matrix is diagonal, with each diagonal entry equal to the inverse of the estimated variance of the observation "measurement" error, where "measurement" error is defined more broadly than might be expected, in that some types of model error are included. This weighting will result in parameter estimates with the smallest possible variance if (1) the estimated variances and the 
model are accurate, (2) the model is effectively linear, and (3) the number of observations is asymptotically large (Bard, 1974). In addition to variances, MODFLOW-2000 permits the designation of standard deviations or coefficients of variation, from which variances are calculated as described by Hill and others (2000, p. 39-40, 53, 57, 65). These indicators of measurement precision are determined on the basis of an analysis of likely measurement error.

In MODFLOW-2000, initial parameter values are assigned and then are changed using a modified Gauss-Newton method (Hill, 1998, p. 7-13) such that equation 1 is minimized. The resulting values are called optimal parameter values. This procedure is repeated for each conceptual model considered.

\section{Parameter Definition}

Parameters may be defined to represent most physical quantities of interest, such as hydraulic conductivity and recharge. MODFLOW-2000 allows these spatially distributed physical quantities to be represented using zones over which the parameter is constant, or using more sophisticated interpolation methods. In either case, multipliers or multiplication arrays can be used to modify parameter values in a known way.

\section{Parameter Sensitivities}

As part of the regression, sensitivities are calculated as: $\partial y_{\mathrm{i}}^{\prime} / \partial b_{j}$, the partial derivative of the simulated hydraulic head or flow, $y_{i}^{\prime}$, with respect to the jth estimated parameter, $b_{j}$, using the sensitivity-equation method as described by Hill and others (2000, p. 6770). Because the ground-water flow equations are nonlinear with respect to many parameters, sensitivities calculated for the same parameter for different sets of parameter values will be different.

Besides being used in the regression calculations, sensitivities are useful to the modeler because they reflect how important each measurement is to the estimation of each parameter. The composite scaled sensitivity (CSS) is a statistic that summarizes all the sensitivities for one parameter and, therefore, indicates the cumulative amount of information that the measurements contain toward the estimation of that parameter. Because they are dimensionless, composite scaled sensitivities can be used to compare the amount of information provided by various types of data for different types of parameters. Using the weight matrix
$W$ in equation 1 , composite scaled sensitivity for parameter $j, C S S_{j}$, is calculated as:

$$
C S S_{j}=\left\{\left[\Sigma_{i=1, n} W_{i}\left(\partial y_{i}^{\prime} / \partial b_{j}\right)^{2} b_{j}^{2}\right] / n\right\}^{1 / 2}
$$

Parameters with large CSS values relative to those for other parameters are likely to be easily estimated by the regression; parameters with smaller CSS values are likely to be difficult or impossible to estimate. For some parameters, the available measurements may not provide enough information for estimation. In this circumstance, the parameter value will need to be set by the modeler, or more head and flow measurements will need to be added to the regression. Parameters with values set by the modeler are called unestimated parameters. Composite scaled sensitivities calculated for different sets of parameter values will be different (Hill, 1998, p. 42), but in this work they are rarely different enough to indicate that a previously unestimated parameter can subsequently be estimated.

An alternative to setting a parameter value is to use prior information on the parameter. This alternative is especially important when evaluating prediction uncertainty because it allows measures of uncertainty in model predictions, such as confidence intervals, to reflect uncertainty in the unestimated parameter. Prior information was not used in the calibration of the DVRFS model but can be included later as needed for prediction uncertainty.

Confidence intervals on the estimated parameter values can be calculated using linear (first-order) theory with sensitivities calculated for the optimal parameter values (Hill and others, 1998, p. 523). Parameters with a large CSS tend to have small confidence intervals. Confidence intervals are useful when trying to decide how many parameters are needed to represent, for example, the hydraulic-conductivity distribution. If, for example, four zones are considered to be important, but the regression yields estimates that are within the confidence intervals related to two or more of the zones, it is likely that fewer zones are adequate. If the regression using fewer zones yields a similar model fit to the measurements, the available measurements are insufficient to distinguish between a model with four zones and one with fewer zones. 


\section{Model Construction}

The 3D hydrogeologic data sets describing the DVRFS were discretized to develop the input arrays required for MODFLOW-2000. Because the various 3D hydrogeologic data sets were developed at grid cell resolutions ranging from 100 to $1,500 \mathrm{~m}$, their discretization to a common, larger grid cell resolution inevitably results in further simplification of the flowsystem conceptual model and hydrogeologic framework model. This resampling and simplification of the 3D hydrogeologic data sets was apparent in (1) definition of the model grid, (2) assignment of boundary conditions, and (3) definition of model parameters.

\section{Grid Definition}

The model consists of 194 rows, 160 columns, and 15 layers. The 465,600-cell model is oriented exactly north-south and encompasses about $70,000 \mathrm{~km}^{2}$ (fig. 15). The lower, left-corner origin of the grid was located at UTM coordinates $(\mathrm{X} ; \mathrm{Y}=437,000 ; 3,928,000 \mathrm{~m})$. Grid discretization along both rows and columns was set to $1,500 \mathrm{~m}$. The 15 model layers represent hydrogeologic units at depths and thicknesses described in table 5. Model layer thickness increases with increasing depth, which allows for higher resolution at the top of the flow model where hydrologic and geologic conditions are more constrained by field observations.

\section{External Boundary Conditions}

The boundaries of the DVRFS model differ somewhat from the two previous DOE regional ground-water flow model studies (fig. 1). The currently defined boundaries for this flow model reflect those that are generally included in most previous investigations. There are, however, some notable exceptions. The northern boundary conforms mostly to the boundary of the Death Valley regional flow system (fig. 7) defined by Harrill and Prudic (1998). Differences occur where the flow model boundary is aligned to include Penoyer Valley and the southern part of southern Railroad Valley to be consistent with the boundary of the UGTA regional model (fig. 1; fig. 7). The western boundary is coincident with the boundary defined by Harrill and Prudic (1998) and differs from previous regional groundwater flow models in that it extends the boundary to the surface-water divide along the Cottonwood Moun- tains and Panamint Range. The southern boundary includes areas southeast of Panamint Valley and west of the Owlshead Mountains (fig. 1) that were interpreted by Bedinger and others (1989) to contribute to the ground-water system. The southeastern boundary of the flow model is aligned approximately along the crest of the southern Spring Mountains to be coincident with the Keystone thrust. The HFM results suggest that the Keystone thrust forms an effective barrier between LCA units in the hanging wall and Mesozoic clastic rocks in the footwall. The southern boundary also excludes Silurian, Valjean, and Shadow Valleys from the flow model. For simulation purposes, the eastern boundary of the DVRFS flow model has been defined to coincide with the Gass Peak thrust. This flow model boundary was defined such that the effectiveness of the Gass Peak thrust as an impermeable boundary could be evaluated. Likewise, the flow model boundary was extended along the axis of Pahranagat Lakes (fig. 16). The western half of Pahranagat Valley is included in the simulation and Pahranagat Lakes were used as constant-head boundaries to allow the numerical simulation to calculate whether a ground-water divide between these two valleys is a justifiable conclusion.

Table 5. Thickness and depth to top of each model layer

\begin{tabular}{rcc}
\hline Layer & $\begin{array}{c}\text { Layer } \\
\text { thickness, } \\
\text { in meters }\end{array}$ & $\begin{array}{c}\text { Depth to top of layer } \\
\text { below top of flow } \\
\text { model, in meters }\end{array}$ \\
\hline 1 & 50 & 0 \\
2 & 50 & 50 \\
3 & 50 & 100 \\
4 & 100 & 150 \\
5 & 100 & 250 \\
6 & 100 & 350 \\
7 & 100 & 450 \\
8 & 100 & 550 \\
9 & 100 & 650 \\
10 & 100 & 750 \\
11 & 150 & 850 \\
12 & 200 & 1,000 \\
13 & 250 & 1,200 \\
14 & 250 & 1,450 \\
15 & 300 & 1,700 \\
\hline
\end{tabular}




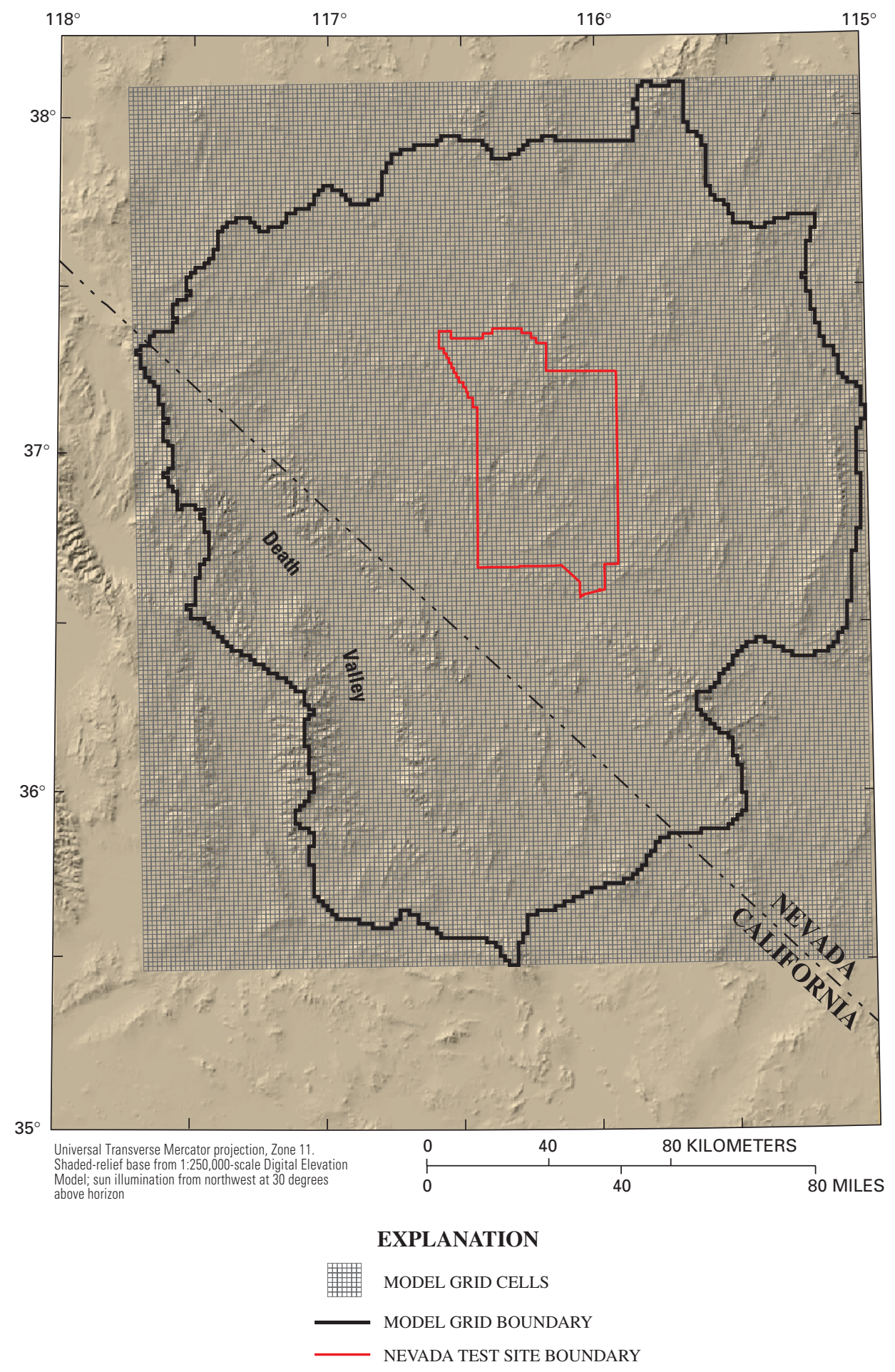

Figure 15. Location of Death Valley regional flow system model grid. 


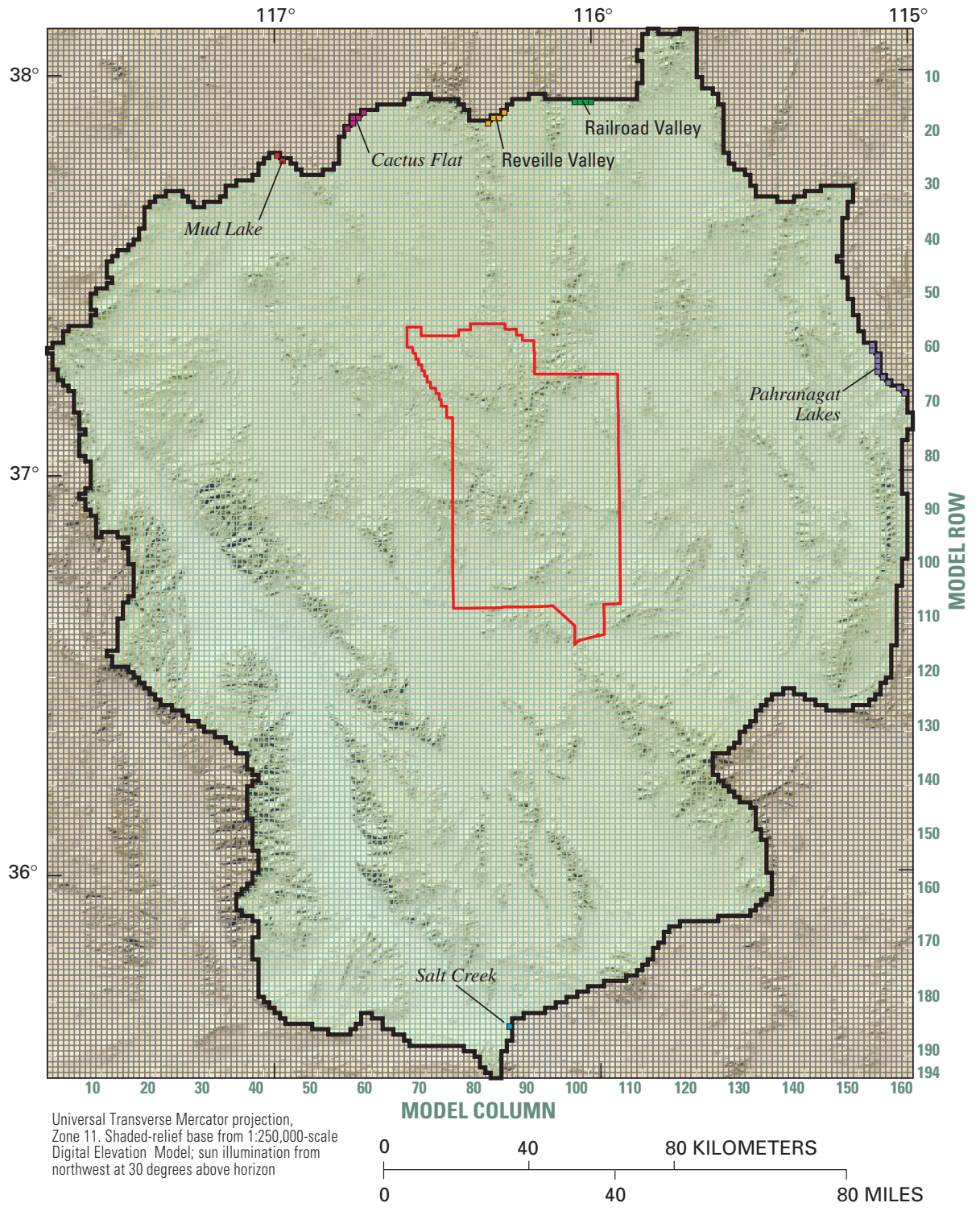

\section{EXPLANATION}

ACTIVE MODEL GRID CELLS

INACTIVE MODEL GRID CELLS

- CONSTANT-HEAD CELL WITH NAME-Color in cells for differentiation only. Cell names in nonitalic type were tested during calibration, but not simulated in calibrated model

- MODEL GRID BOUNDARY—No-flow conditions NEVADA TEST SITE BOUNDARY

Figure 16. Death Valley regional flow system model boundary conditions and constant-head cells. 
The extent of active and inactive flow model cells are similarly defined. The extent of defined active cells - that is, those cells within the model boundaryis the same in all layers (fig. 16). In layer 1, all lateral boundaries were designated as no-flow except along the eastern boundary at Pahranagat Lakes, the northern boundary at Mud Lake and Cactus Flat, and the southern boundary at Salt Creek. Cells in these locations were defined as constant-head boundaries. Hydraulic-head values assigned to Pahranagat Lakes reflect the perennial lake levels supported by groundwater flow out of the system. At Mud Lake and Cactus Flat, hydraulic heads interpreted from water levels in wells were used to represent the water table immediately north of the model boundary. At Salt Creek, the land-surface elevation was assigned as the hydraulichead value to represent the water table expressed at the land surface as ground-water discharge. There are only no-flow boundaries in the remaining model layers. During calibration several additional constant-head boundaries were evaluated at Reveille Valley and southern Railroad Valley (fig. 7 and fig. 16).

\section{Representation of the Hydrogeologic System}

\section{Hydrogeologic Units}

The discretization of the HFM into numerical flow-model input arrays involved the export of hydrogeologic units from the framework model into a series of surfaces that defined the top of each hydrogeologic unit. These surfaces were utilized by the MODFLOW-2000 hydrogeologic-unit flow (HUF) package (Anderman and Hill, 2000) to define the geometry of the hydrogeologic units for the flow model.

The MODFLOW-2000 (Harbaugh and others, 2000) HUF package (Anderman and Hill, 2000) allows incorporation of the framework model into the flow model. This was done by inputting the top altitude and thickness grids developed from the framework model as flow-model arrays. This represents a significant increase in the efficiency of linking the framework model and the flow model. Essentially, the HUF package allows the flow model itself to resample the framework model's hydrogeologic units into the flow-model grid, with HUF determining which hydrogeologic unit is in each flow-model layer. This gives the user great flexibility in the ability to change the flow-model geometry without the tedious process of manual resampling efforts.

The altitudes of the top of the cells constituting each hydrogeologic unit from the framework model were exported. This produced a series of grids that only contain altitude values where a hydrogeologic horizon exists in the 3D model. It is important to note that because the altitude values contained in the hydrogeologic unit grids are from the horizontal center of the cells representing the 3D model, the limits of these grids are somewhat different than the original grids used to construct the model. The grids used to construct the model are node-based with the altitudes being assigned to the points existing at the corners of the cells constituting the model. The exported grids are cell-based with the altitude being assigned to the center of the cell constituting the model.

Variations in the hydraulic properties of hydrogeologic unit parameters are defined using ZONE arrays. Zone arrays distinguish between regions within a hydrogeologic unit that have different hydraulic conductivity values.

\section{Hydrogeologic Structures}

In this model, the horizontal-flow barrier (HFB) package (Hsieh and Freckleton, 1993) was used to simulate relatively thin, vertical, low-permeability geologic features that impede the horizontal flow of ground water. The features are approximated as a series of explicitly represented relative barriers situated on the boundaries between pairs of adjacent cells in the finite-difference grid.

The subset of mapped faults chosen to be incorporated as relative barriers in the flow model was sampled into a "stair-step" pattern of cell boundaries that closely approximate the location of the mapped faults. The locations of these cell boundaries were then specified for input to MODFLOW-2000. For simplicity, the faults were assumed to extend through the entire thickness of the flow model and were assigned a thickness of $1 \mathrm{~m}$. The conductances of these relative barriers were originally assigned relatively small values on the order of $10^{-6} \mathrm{~m}^{2} / \mathrm{d}$. A description of all faults simulated with the HFB package is provided in table 6 .

\section{Evapotranspiration and Spring Flow}

In the DVRFS model, ground-water discharge, including ET and spring flow, is simulated using the 
Table 6. Description of hydrogeologic features defined as horizontal-flow barrier (HFB) package parameters

\begin{tabular}{|c|c|}
\hline $\begin{array}{l}\text { Parameter } \\
\text { name }\end{array}$ & Feature description \\
\hline HFBRestSpr & Unnamed southern extension of Furnace Creek fault zone; east side of central Death Valley "igneous rhombochasm" \\
\hline HFBAmargos & Amargosa River fault \\
\hline HFBAshMead & Combined Amargosa River fault/Stewart Valley fault \\
\hline HFBBareMtn & Fluorspar Canyon detachment fault \\
\hline HFB_DeathV & Death Valley fault zone \\
\hline HFBEagleMt & $\begin{array}{l}\text { Unnamed transition zone to southern extension of Furnace Creek fault zone; northeast side of central Death Valley } \\
\text { "igneous rhombochasm" }\end{array}$ \\
\hline HFBFurnace & Furnace Creek fault zone \\
\hline HFB_LVVSZ & Las Vegas Valley shear zone \\
\hline HFBPahrump & Pahrump-Stewart Valley-State Line fault zone \\
\hline HFBTecopa & Greenwater Valley fault zone \\
\hline HFBTecPass & Sheephead fault zone \\
\hline HFBGravity & Gravity fault \\
\hline HFB_IndSpr & Unnamed splay of the Las Vegas Valley shear zone \\
\hline HFB_Pahute & $\begin{array}{l}\text { Western boundary of the Silent Canyon caldera complex, corresponds to the northern part of the Thirsty Canyon } \\
\text { lineament }\end{array}$ \\
\hline HFB_KeaneW & Keane Wonder fault \\
\hline HFB_CDVFCF & Central Death Valley-Furnace Creek fault zone \\
\hline HFB_Saratog & Southern Death Valley fault zone \\
\hline HFB_NDVFCF & Northern Death Valley-Furnace Creek fault zone \\
\hline HFBCraterF & Crater Flat fault \\
\hline HFBSolitar & Solitario Canyon fault \\
\hline HFBHwy95 & Highway 95 fault \\
\hline HFBBareMtF & Bare Mountain fault \\
\hline HFBStewart & Pahrump-Stewart Valley-State Line fault zone \\
\hline HFB_Eleana & Eastern (and southern) limit of Eleana Formation involved in footwall thrust duplex of the Belted Range thrust \\
\hline HFB_NCFYM & Projected subsurface trace of the CP thrust \\
\hline HFBBullfrog & Bullfrog Hills detachment \\
\hline
\end{tabular}

drain (DRN) package (McDonald and Harbaugh, 1988). The DRN package simulates ground-water discharge through a head-dependent boundary. Ground water discharges from the cell in which the drain is specified when the simulated head in the cell rises above the drain elevation.

For the DVRFS model, each discharge area was subdivided into one or more zones. These zones define subareas within the main ground-water discharge area typically associated with a major spring or spring group. Figure 17 illustrates this zonal breakdown in the Oasis Valley discharge area. Spatial distributions of ET units obtained from Laczniak and others (2001), Malmberg (1967), U.S. Department of Energy (1997), and DeMeo and others (1999) were overlaid on the model grid. The overlay was used to compute the area of an ET unit within model nodes and ET zones of a discharge area. The grid definition of all discharge areas simulated in the DVRFS model is presented in figure 18.

\section{Recharge}

To define ground-water recharge using the $\mathrm{RCH}$ package, the net infiltration model provided by Hevesi and others (2002) was resampled to a 1,500-m grid. In the initial model configuration, recharge was defined using one parameter that varied the net influx of ground water by a multiplicative factor for the entire model domain. Subsequent model runs utilized a zone array of up to 13 zones representing the major rock types within the hydrogeologic framework model that 

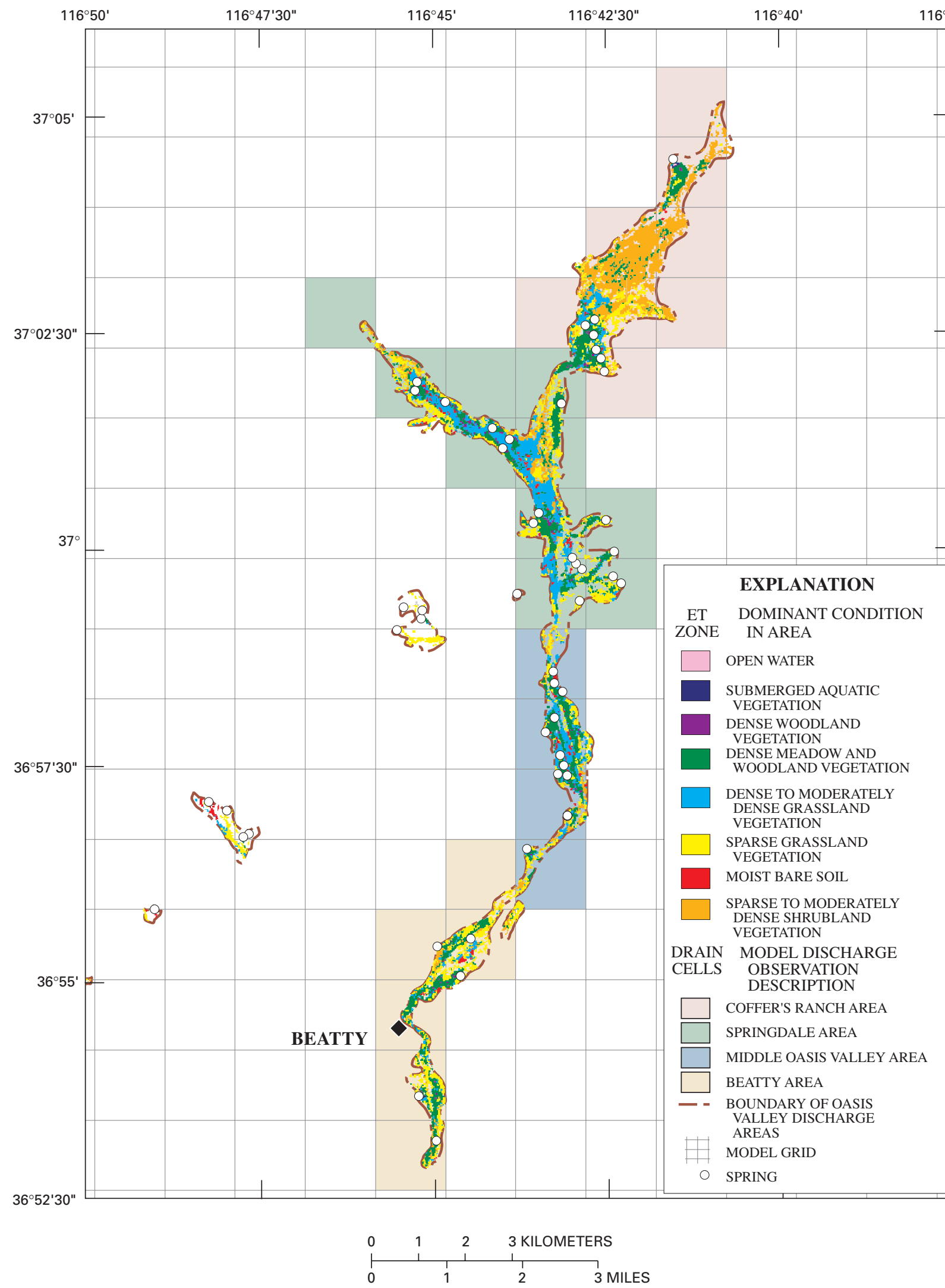

Figure 17. Delineation of evapotranspiration (ET) units and zones in the Oasis Valley discharge area, Nevada (Laczniak and others, 2001). 

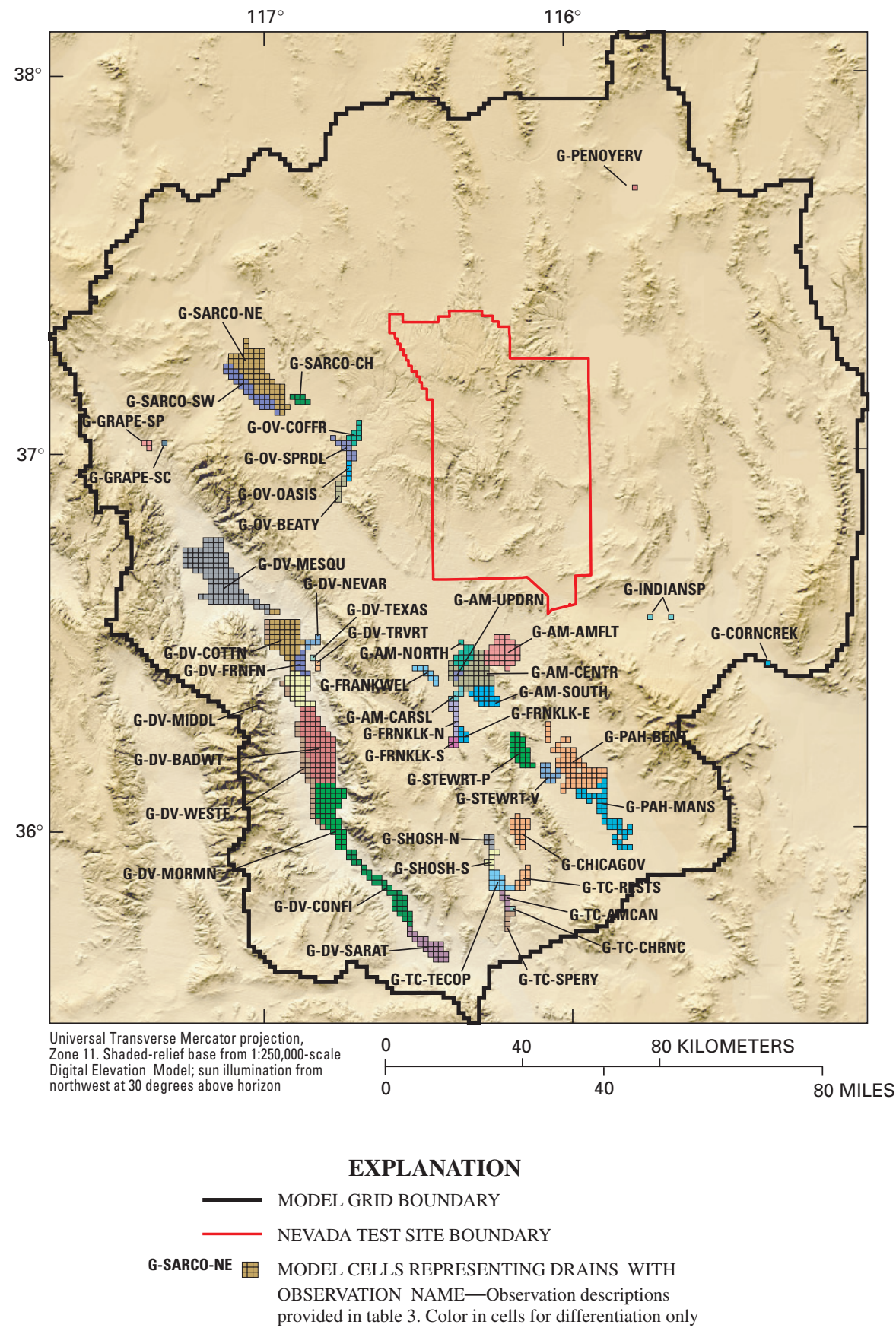

Figure 18. Model cells representing drains used to simulate ground-water discharge from the Death Valley regional flow system model.

occur at the estimated water table (fig. 19). Parameters were defined as multiplicative factors for net infiltration and they are described in table 7 . The net effect is a modification of the INFIL rates provided by Hevesi and others (2002) by some factor that is dependent on the rock type at the water table. This modification is interpreted as representing processes that would other- wise redirect infiltrating water between the root zone and the water table.

\section{Observation Data}

Measured hydraulic heads and ground-water discharges and their corresponding weights were used by MODFLOW-2000 during parameter estimation to 


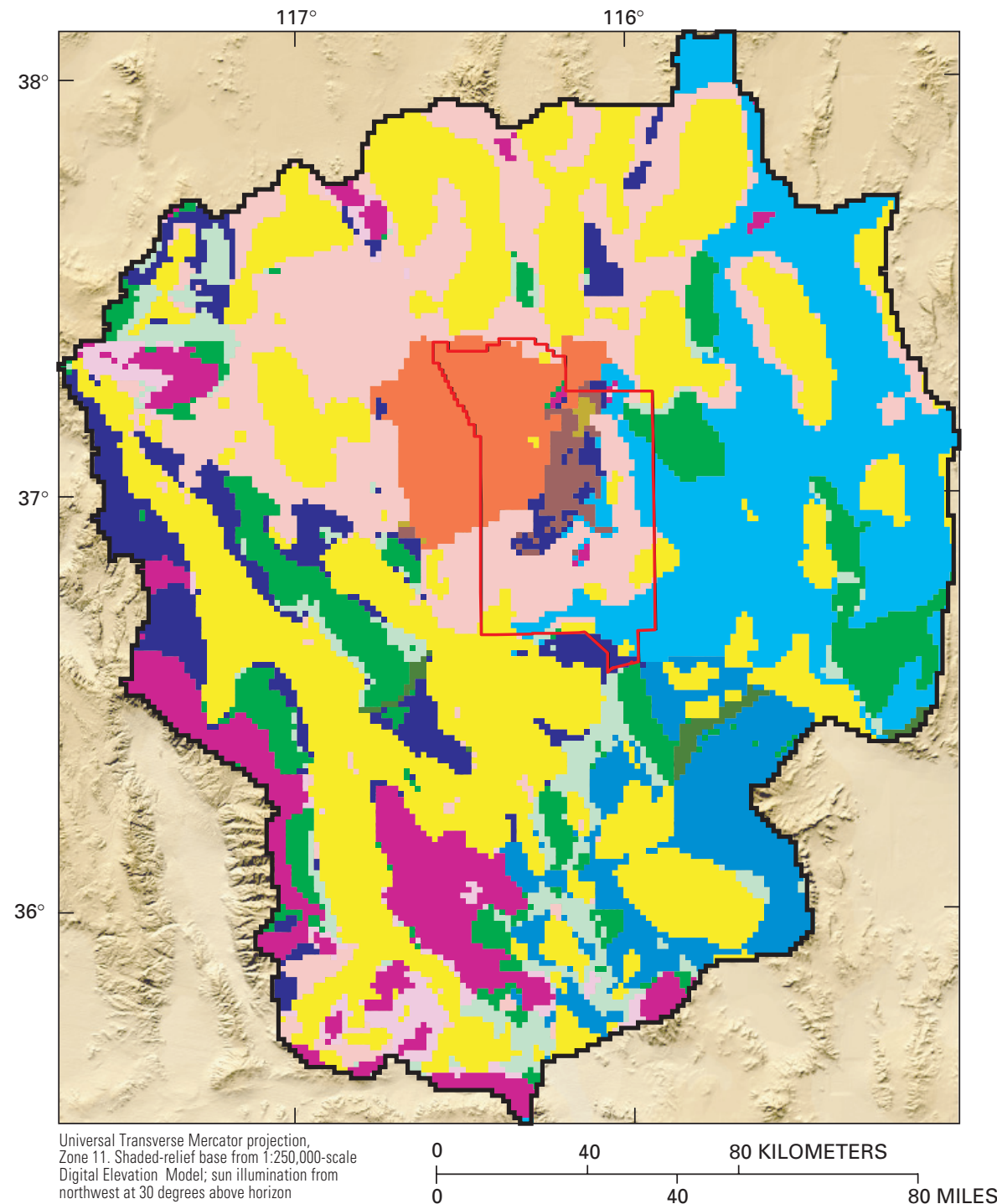

\section{EXPLANATION}

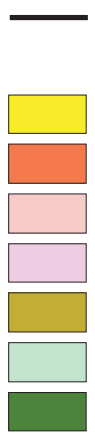

MODEL GRID BOUNDARY

— NEVADA TEST SITE BOUNDARY RECHARGE ZONE-

1. BASIN FILL

2a. VOLCANICS - TIMBER MOUNTAIN

2b. VOLCANICS - ALL OTHER

3a. CRYSTALLINE - UPPER TJi AND pCgm

3b. CLASTIC - UPPER UCCU

3c. CLASTIC - UPPER LCCU AND Mvs

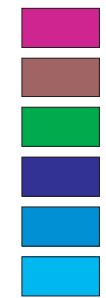

4a. CRYSTALLINE - LOWER TJi AND pCgm

4b. CLASTIC - LOWER UCCU

4c. CLASTIC - LOWER LCCU

5a. CARBONATES (WEST)

5b. CARBONATES (SPRING MOUNTAIN)

3d. CLASTIC - LCCU THRUSTS

Figure 19. Recharge zone multiplication array representing hydrogeologic units at the water table. 
Table 7. Description of recharge parameters defined for the recharge zones shown in figure 19

\begin{tabular}{|c|c|}
\hline Parameter name & Description \\
\hline RCH_zone1 & Recharge on basin-fill units \\
\hline $\mathrm{RCH} \_z o n e 2 \mathrm{a}$ & Recharge on volcanic Timber Mountain units \\
\hline $\mathrm{RCH}$ zone2b & Recharge on volcanic units outside of the Timber Mountain area \\
\hline $\mathrm{RCH} \_z o n e 3 \mathrm{a}$ & Recharge on crystalline units TJi and pCgm, depths less than 300 meters \\
\hline $\mathrm{RCH} \_z o n e 3 b$ & Recharge on clastic unit UCCU, depths less than 300 meters \\
\hline $\mathrm{RCH} \_z o n e 3 \mathrm{c}$ & Recharge on clastic units LCCU and Mvs, depths less than 300 meters \\
\hline RCH_zone3d & Recharge on clastic units LCCU thrusts \\
\hline RCH_zone4a & Recharge on crystalline units TJi and pCgm, depths greater than 300 meters \\
\hline $\mathrm{RCH}$ _zone4b & Recharge on clastic unit UCCU, depths greater than 300 meters \\
\hline RCH_zone4c & Recharge on clastic unit LCCU, depths greater than 300 meters \\
\hline RCH_zone5a & Recharge on carbonate units LCA and UCA in the western part of the model \\
\hline RCH_zone5b & Recharge on carbonate units LCA and UCA in Spring Mountain area \\
\hline RCH_zone5c & Recharge on carbonate units LCA and UCA in the northeastern part of the model \\
\hline
\end{tabular}

provide values to define the objective function for the model simulation. The series of analyses conducted to obtain the initial set of hydraulic-head and groundwater discharge weights is described below.

\section{Hydraulic-Head Observations}

Although a large set of water-level data exists for the DVRFS, not all of these data are appropriate for use in the predevelopment, steady-state model. Only those water levels representing regional steady-state conditions existing prior to the onset of pumping, or water levels exhibiting no response to pumping, were used.

The USGS National Water Information System (NWIS) databases in Las Vegas, Nev., and San Diego, Calif., were the ultimate source of all water-level and borehole data used in the DVRFS model. As part of the modeling activity, new or previously omitted borehole and water-level data were entered into these NWIS databases. These databases were believed to be the most comprehensive data sources for water levels in the Death Valley region.

Each water-level measurement was attributed in the project database to identify appropriate data for the flow model. Three attributes were assigned to each water-level measurement. These attributes define the appropriate use of the data ("UseFlag"), the hydrologic conditions the data represented ("ConditionFlag"), and the methods used for analysis ("MethodFlag"). The attributes and their definitions are presented in table 8 , table 9 , and table 10.
Water levels in boreholes with only one waterlevel measurement were automatically attributed with a UseFlag of "Insufficient data." These data were subsequently reviewed to ensure that they were reasonable for inclusion in the flow model. If these data did not appear to represent regional ground-water conditions, the attribute was modified to indicate the appropriate use.

Hydrographs were generated for each borehole with more than one water-level measurement. By reviewing well hydrographs and additional spatial data contained in the accompanying DVRFS database, the appropriate UseFlag and ConditionFlag for each water-level measurement were determined and automatically stored in the DVRFS database. Once all water levels were attributed with a UseFlag, database queries were used to select the appropriate water levels for further analysis.

Well-construction data were used to determine the depth interval where each borehole was open to the flow system. Boreholes used as observations had to have a definable depth interval associated with the hydraulic-head measurement. All boreholes with water-level measurements attributed with a UseFlag of "Steady state (regional scale)" or "Insufficient data" were included in this analysis. If a site had multiple intervals where water could enter the borehole the uppermost and lowermost depths were used. If construction data were not available, the mean water level and the bottom of the well were used to define the open depth interval associated with the water level. If a well or hole depth was not available, the head observation was not used. Boreholes excluded from 
Table 8. Possible "UseFlag" entries used to attribute water-level measurements in the Death Valley regional flow system database. The "UseFlag" indicates data suitability for various types of hydrologic studies and general hydrologic conditions

\begin{tabular}{|c|c|}
\hline UseFlag attribute & Description \\
\hline Steady State (regional scale) & $\begin{array}{l}\text { These data represent predevelopment and(or) reasonable steady-state hydrologic conditions that reflect } \\
\text { the regional potentiometric surface. }\end{array}$ \\
\hline Steady State (local scale) & $\begin{array}{l}\text { These data represent reasonable steady-state hydrologic conditions of a localized potentiometric } \\
\text { surface. }\end{array}$ \\
\hline Transient (regional scale) & $\begin{array}{l}\text { These data represent postdevelopment and(or) consistently changing hydrologic conditions due to } \\
\text { pumping, recharge, and so forth, in boreholes that monitor the regional potentiometric surface. }\end{array}$ \\
\hline Transient (local scale) & $\begin{array}{l}\text { These data represent postdevelopment and(or) changing hydrologic conditions due to pumping, } \\
\text { recharge, and so forth, in boreholes that monitor a localized potentiometric surface or in areas where } \\
\text { the hydrologic conditions do not affect the regional flow system. }\end{array}$ \\
\hline Localized & These data represent localized hydrologic conditions that are not appropriate for regional studies. \\
\hline Insufficient data & $\begin{array}{l}\text { There are not sufficient data to make a definitive determination on the hydrologic conditions or suit- } \\
\text { ability of the data. }\end{array}$ \\
\hline Suspect & $\begin{array}{l}\text { These data appear to be suspicious, in error, or affected by unnatural conditions that preclude their use in } \\
\text { studies of the natural hydrologic flow system. }\end{array}$ \\
\hline Nonstatic level & $\begin{array}{l}\text { These data are affected by testing or construction activities and the water level does not represent static } \\
\text { regional flow-system conditions. }\end{array}$ \\
\hline Superseded & $\begin{array}{l}\text { These data were collected prior to site reconfiguration or modification, and subsequent data collected at } \\
\text { this location, possibly under different site IDs, are more appropriate for hydrologic investigations. }\end{array}$ \\
\hline Duplicate & $\begin{array}{l}\text { These data have been entered more than once because of different parameter codes or data entry error. } \\
\text { The data should not be used for statistical and related analyses. }\end{array}$ \\
\hline None & $\begin{array}{l}\text { These data are known to be erroneous, not representative of the hydrologic system, or are missing crit- } \\
\text { ical information and should not be used in any hydrologic investigation. }\end{array}$ \\
\hline
\end{tabular}

the model because of no available hole depth were located in areas with other head observations, so no additional attempts were made to assign an open depth interval.

Hydraulic-head observation weights are a measure of the observation error. A total observation error expressed as a standard deviation was assigned to each head observation. MODFLOW-2000 calculates the appropriate weight for use in the parameter-estimation process (equation 3). In this discussion "observation error" is analogous to the MODFLOW-2000 input variable "STATISTIC," expressed as a standard deviation, which is assigned to each head observation. More detailed discussions on observation weights can be found in Hill (1998) and Hill and others (2000).

$$
\text { weight }=\frac{1}{\text { STATISTIC }}
$$

weight = relative accuracy of head observation used to calculate the weighted residual, and

STATISTIC = total observation error estimate expressed as a standard deviation.

An estimate of observation error was calculated using accuracy data stored in the database. The potential errors considered include those associated with (1) land-surface altitude, (2) borehole location (latitude and longitude), and (3) measurement method. Each error was expressed as a variance, and they were summed to obtain the total observation variance. This variance was then converted to a standard deviation and used as the observation error.

Land-surface altitude errors were often the largest errors affecting the head observation accuracy. Land surface was the datum used to calculate the head observation in meters above sea level. If this datum was in error by $10 \mathrm{~m}$, the water-level altitude was in error by at least $10 \mathrm{~m}$. The error magnitude was based on the method used to determine the land-surface altitude. If a topographic map was used to locate the borehole, the error was based on the map scale. If a global positioning system (GPS) was used to determine land-

where 
Table 9. Possible "ConditionFlag" entries used to attribute water-level measurements in the Death Valley regional flow system database. Water-level measurement "ConditionFlag" indicates the hydrologic condition(s) that the data represent and supports the "UseFlag" determination

\begin{tabular}{|c|c|}
\hline ConditionFlag attribute & Description \\
\hline Reported perched water & $\begin{array}{l}\text { The site and/or data were identified as representing localized perched-water conditions in a } \\
\text { published report. }\end{array}$ \\
\hline Suspected perched water & $\begin{array}{l}\text { Based on the available data and professional judgment the data appear to represent localized } \\
\text { perched-water conditions. }\end{array}$ \\
\hline Testing area & The data appear to be affected by nuclear testing or other explosive detonations. \\
\hline Declining trend & $\begin{array}{l}\text { The data appear to be part of a discernible, overall downward trend. Possible causes include nearby } \\
\text { pumping, decreased recharge, and drainage. }\end{array}$ \\
\hline Rising trend & $\begin{array}{l}\text { The data appear to be part of a discernible, overall rising trend. Possible causes include recovery } \\
\text { from pumping, precipitation event(s), and proximity to recharge areas. }\end{array}$ \\
\hline Pumping/recovery & $\begin{array}{l}\text { The measurement was made while the site, or nearby site, was being pumped or was recovering } \\
\text { from pumping. }\end{array}$ \\
\hline Pumping area & The site is located in an area that has been impacted by ground-water withdrawals. \\
\hline Equilibration & $\begin{array}{l}\text { The water level appears to be part of a discernible, overall trend that is approaching an equilibrium } \\
\text { level, either higher or lower than the initial measurement. }\end{array}$ \\
\hline Undeveloped & $\begin{array}{l}\text { The data do not accurately represent hydrologic conditions because of insufficient borehole } \\
\text { development. }\end{array}$ \\
\hline Dry & $\begin{array}{l}\text { The site was dry at the time of the measurement. The water level has dropped below the bottom of } \\
\text { the borehole or access tube. }\end{array}$ \\
\hline Suspect & $\begin{array}{l}\text { The water level is grossly different in magnitude or trend from other data at the same or nearby } \\
\text { sites. Data may have been measured inaccurately or entered incorrectly. }\end{array}$ \\
\hline Erratic/Unstable & $\begin{array}{l}\text { The data are erratic, due to unknown causes, and probably do not represent actual hydrologic condi- } \\
\text { tions. The validity of the data cannot be determined. }\end{array}$ \\
\hline Insufficient data & $\begin{array}{l}\text { There are not sufficient data to make a determination on the hydrologic conditions at the time of the } \\
\text { measurement. }\end{array}$ \\
\hline Consistent & The data appear to be part of a reasonably consistent level or cyclic trend maintained at the site. \\
\hline Precipitation response & $\begin{array}{l}\text { The data appear to be responsive to localized precipitation events, which might suggest a localized } \\
\text { hydrologic system. }\end{array}$ \\
\hline Missing & $\begin{array}{l}\text { Critical associated data are missing that make the data useless. For example, no date with a water- } \\
\text { level measurement. }\end{array}$ \\
\hline Anomalous - high & The water level is higher or larger in magnitude than equivalent data at this site or nearby sites. \\
\hline Anomalous - low & The water level is lower or smaller in magnitude than equivalent data at this site or nearby sites. \\
\hline Other & $\begin{array}{l}\text { The data do not fit into any other category. A description of the hydrologic condition should be } \\
\text { added to the remark field. }\end{array}$ \\
\hline
\end{tabular}

surface altitude, the error was based on the accuracy of the GPS system.

Borehole-location (latitude and longitude) error introduces additional land-surface altitude error because the correct altitude cannot be obtained if the borehole is not accurately located. This potential error increases if the borehole is located in a steep-slope area. A simple method was developed to convert these horizontal errors into vertical errors. The land-surface slope was used as an approximation for the potentiometric-surface slope, and the slope at each head-observation location was calculated using a digital elevation model (DEM). Location-accuracy data stored in the database were used if available, but if no data were available it was assumed that the borehole location error was \pm 1 minute of longitude. Horizontal borehole-location error was converted to a vertical accuracy (eq. 4):

$$
Z=(X \tan \theta)
$$

where

$$
\begin{gathered}
Z \quad \text { vertical error due to horizontal borehole-loca- } \\
\text { tion accuracy } \\
X \quad=\text { horizontal borehole-location accuracy, and }
\end{gathered}
$$


Table 10. Possible "MethodFlag" entries used to attribute water-level measurements in the Death Valley regional flow system database. Water-level measurement "MethodFlag" indicates the analytical methods used to analyze the data and to determine the "UseFlag" and general hydrologic conditions

\begin{tabular}{|c|c|}
\hline MethodFlag attribute & Description \\
\hline Graphical & $\begin{array}{l}\text { Data were visually inspected using graphical methods such as hydrographs, so that trends and anoma- } \\
\text { lous data could be identified. }\end{array}$ \\
\hline Spatial & $\begin{array}{l}\text { Data were analyzed to determine if they agreed with regional trends, spatial hydrologic conditions, } \\
\text { and(or) were reasonable given data from nearby sites. }\end{array}$ \\
\hline Supporting & $\begin{array}{l}\text { Data were analyzed and compared to supporting data types such geology, precipitation, recharge, perti- } \\
\text { nent reported information, and so forth. }\end{array}$ \\
\hline Construction & $\begin{array}{l}\text { Data were analyzed and compared to the site construction and configuration, which may affect the } \\
\text { measured data value. }\end{array}$ \\
\hline Criteria & $\begin{array}{l}\text { Data were analyzed and compared to various criteria that are indicative of specific hydrologic condi- } \\
\text { tions. For example, there is generally no single factor or type of data that is available to determine if } \\
\text { a water level is perched, so several types of data can be used collectively to make a determination. }\end{array}$ \\
\hline Reported & $\begin{array}{l}\text { Data were reported in a published document as having the hydrologic condition(s) specified by the } \\
\text { "ConditionFlag." }\end{array}$ \\
\hline Query & The data were selected by a database query. \\
\hline
\end{tabular}

$\theta \quad=$ land-surface slope at borehole location (used as an approximation of the potentiometric-surface slope).

Measurement method was a relatively minor source of error associated with hydraulic-head observations. An accuracy was assigned to each water-level measurement based on the measurement method stored in the database (table 11). Each observation used the mean accuracy of all measurements with a UseFlag of "Steady state (regional scale)" or "Insufficient data."

Water-level measurement variability was analyzed and was found to be an inconsequential source of error. By definition water-level measurements selected for inclusion in the flow model had minimal variability. These measurements were selected because they represented a consistent water level. The mean of all appropriate measurements sufficiently accounted for the natural water-level variability.

A minimum observation error was assigned because some observations had standard deviations that were too small given the flow-model construction. It was unreasonable to restrict the parameter-estimation process to match head observations within $2 \mathrm{~m}$. Head observations with a UseFlag of "Insufficient data" were assigned a minimum standard deviation of $5 \mathrm{~m}$, and "Steady state (regional scale)" observations were assigned a minimum standard deviation of $3 \mathrm{~m}$.
A summary of the initial standard deviations assigned to head observations is presented in figure 20 .

Table 11. Accuracy assigned to water-level measurements based on method of measurement

\begin{tabular}{lc}
\hline \multicolumn{1}{c}{ Method description } & $\begin{array}{c}\text { Accuracy, } \\
\text { in feet }\end{array}$ \\
\hline Airline measurement & 2.0 \\
Analog or graphic recorder & 2.0 \\
Calibrated airline measurement & 1.0 \\
Calibrated electric-tape measurement & 0.5 \\
Electric-tape measurement & 0.5 \\
Estimated & 50 percent of depth-to- \\
& water value \\
Interpreted from geophysical logs & 3.0 \\
Manometer measurement & 1.0 \\
Nonrecording gage & 2.0 \\
Other & 2.0 \\
Pressure-gage measurement & 1.0 \\
Reported-method not known & 1.0 \\
Steel-tape measurement & 0.5 \\
\hline
\end{tabular}




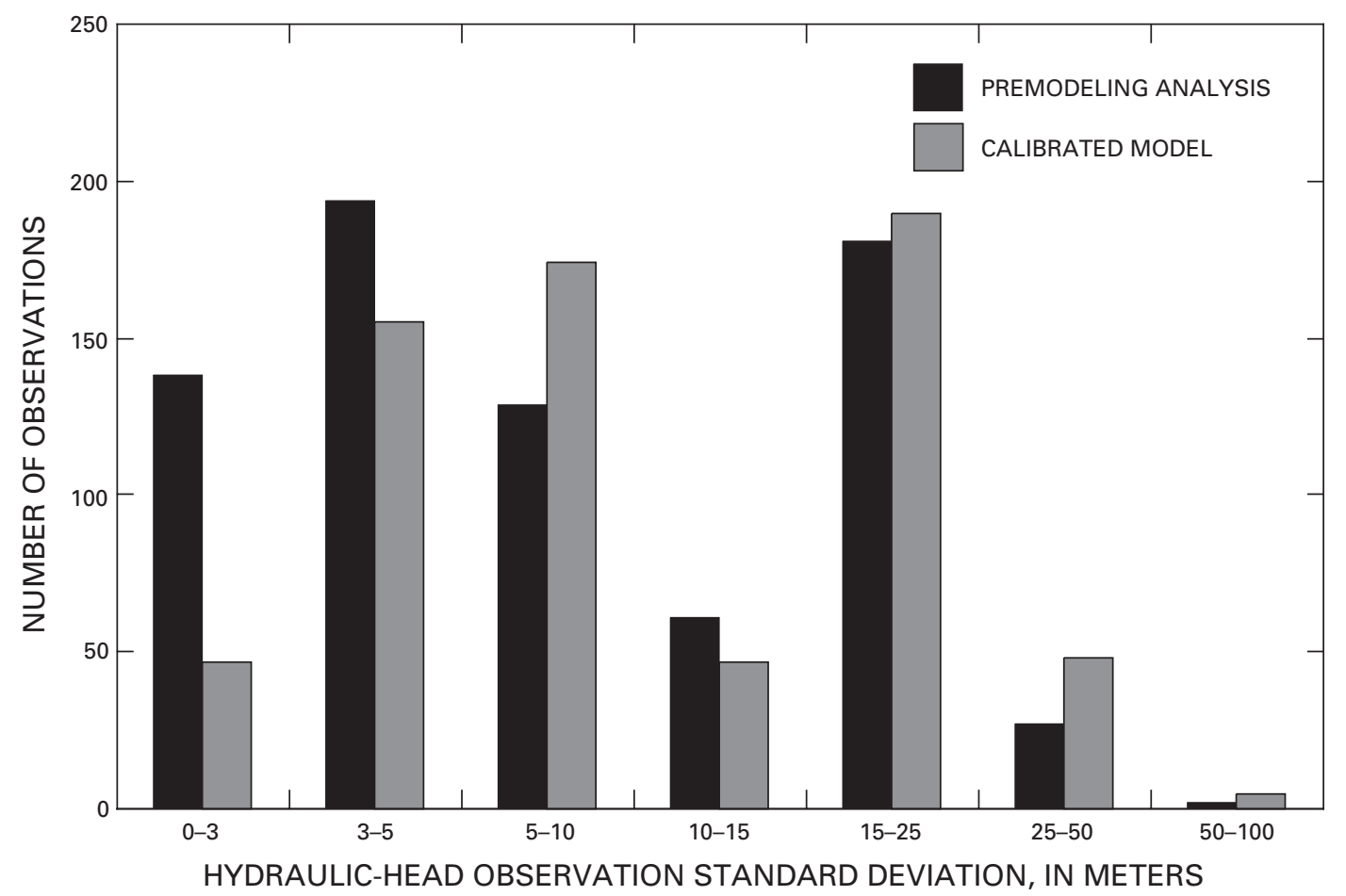

Figure 20. Distribution of standard deviation values assigned to hydraulic-head observations to determine weights from the premodeling observation analysis and the calibrated model.

\section{Ground-Water Discharge Observations}

Laczniak and others (2001; appendix) presented a formal analysis assessing the uncertainty of their estimates of ground-water ET using a Monte Carlo simulation approach. The Monte Carlo simulation generated statistics of ground-water ET from each discharge area by using randomly generated values of the variables used to compute ground-water ET. These variables included (1) the area of each ET unit, (2) the average annual ground-water ET rate of each ET unit within a discharge area, and (3) the average annual precipitation of each discharge area. In generating random values for these variables, the simulation assumed that each variable was independent and normally distributed about a mean equal to the value used by Laczniak and others (2001) to compute ground-water ET. Values generated for each parameter were constrained by a probability distribution defined in terms of a coefficient of variation $(\mathrm{CV})$, where $\mathrm{CV}$ is the standard deviation divided by the mean. Values of $\mathrm{CV}$ used to generate ET rates were determined from ranges given in Laczniak and others (2001) describing the expected variation of the ET rate within each ET unit. CV values were computed on the assumption that ranges represented \pm 2 standard deviations of a normal population. CV values used to generate annual precipitation rates within a discharge area were determined from statistics determined from long-term measurements made by the National Weather Service at weather stations within or near each discharge area. $\mathrm{CV}$ values used to generate ET-unit areas were assumed to be 10 percent.

Uncertainty for each discharge area was calculated from the mean and standard deviation generated by 1,000 realizations of a Monte Carlo simulation and was expressed in terms of a CV (Laczniak and others, 2001). A higher CV implies a greater uncertainty in the estimate of ground-water discharge. Simulated CV values ranged from 0.10 to 0.56 . Based on this analysis, ground-water ET estimates for Oasis Valley (10 percent) and Tecopa basin, central area (12 percent) are the most certain and those for Stewart Valley (56 percent) and Sarcobatus Flat (46-55 percent) are the least certain. In general, discharge areas dominated by open playa and those with fewer ET units were the most uncertain. Final CV values used in the DVRFS model are listed in table 3. A similar approach was used to determine $C V$ values for ground-water discharge rates not developed by the Laczniak and others (2001) study. 


\section{Model Calibration}

During calibration, a number of conceptual models were evaluated using the regression methods in MODFLOW-2000. A best fit to hydraulic-head and ground-water discharge observations was calculated for each conceptual model. Evidence of model error or data problems was investigated after each model run. These analyses were used in conjunction with independent hydrogeologic data to modify, and hopefully improve, the existing conceptual model, observation data sets, and weighting.

\section{Conceptual Model Variations}

Four major types of conceptual model variations were evaluated to test those components of the ground-water system about which the least is known. These modifications included changes to (1) the location and type of flow-system boundary conditions,

(2) the definition of discharge areas, (3) the definition of recharge areas, and (4) the configuration of hydrogeologic framework features. For each change in the conceptual model, a new set of parameters was estimated using MODFLOW-2000, and the resulting new simulated hydraulic heads and ground-water discharges were compared with observed values. Only those conceptual model changes contributing to significant ( $>10$ percent) improvement in model fit during a given optimization run, as indicated by a reduction in the sum of squared errors (equation 1), were retained in the final optimized model. Variations in hydrogeologic framework interpretation contributed most to improving the numerical model fit.

\section{Location and Type of Boundary Conditions}

During model calibration several different boundary configurations were simulated to evaluate flow and no-flow assumptions along the northern model boundary. Limited water-level data made it difficult to determine if ground-water divides exist in these areas. Previous investigations have suggested southward ground-water flow from many of the adjacent northern basins (Eakin, 1962; Rush, 1968, 1970). Constant-head cells were evaluated in the Mud Lake, Cactus Flat, Reveille Valley, and Railroad Valley areas (fig. 16).

In early simulations, the northern part of the model did not have adequate amounts of water entering the system as natural infiltration to support hydraulic heads and ground-water discharges. Because the recharge model provided by Hevesi and others (2002) was considered a "high-end" estimate of recharge, a water source other than infiltration was required to raise water levels and increase flow to ground-water discharge areas. Four groups of constant-head cells were simulated to test hypotheses of interbasinal flow from these northern regions.

Constant-head cells along the northern model boundary (fig. 16) were evaluated with the cells defined in multiple configurations, including layer 1 , and layers $1-15,1-10$, and $1-5$ (table 5). The volume of water flowing into the model with cells in multiple layers was excessive in most cases. In the calibrated model a reasonable volume of water entered the model with the constant-head cells in layer 1 for Mud Lake and Salt Creek. The Cactus Flat area, however, needed constant-head cells in layers 5-10 to allow a reasonable volume of water into the model. In the calibrated model water exited the flow model at the layer 1 constant-head cells in the Pahranagat Lake areas (net $21,400 \mathrm{~m}^{3} / \mathrm{d}$ ).

The Mud Lake constant-head group (fig. 16) consisted of 2 cells in layer 1 . Few water-level data were available to determine the altitude of the constant heads. The two nearest boreholes with water-level measurements were approximately $10 \mathrm{~km}$ north and $30 \mathrm{~km}$ south of the model boundary. Water levels in these boreholes indicated a southward gradient into the model. The cell elevations were set about $15 \mathrm{~m}$ below the water level at the closest model head observation. Water entering the model through these constant-head cells was important for maintaining hydraulic heads throughout the northwestern part of the model and for discharge at Sarcobatus Flat and Grapevine Spring. These constant-head cells were used in the final calibrated model and there was a net inflow of $16,500 \mathrm{~m}^{3} / \mathrm{d}$.

Constant-head cells were evaluated in Cactus Flat because of low hydraulic heads in the Cactus Flat and Gold Flat areas as well as low discharge at Sarcobatus Flat and Grapevine Spring. This constant-head group (fig. 16) consisted of 5 cells in layer 1. Water levels near the model boundary indicate that prior to development a ground-water divide probably existed. These constant-head cells were quite effective at improving hydraulic heads or ground-water discharge residuals. For these reasons this constant-headboundary group was included in the final flow model configuration, and there was an inflow of $25,500 \mathrm{~m}^{3} / \mathrm{d}$. 
The Reveille Valley constant-head boundary (fig. 16) consisted of 4 cells in layer 1 . There were no water-level data in this valley, so it was not possible to estimate the hydraulic gradient. A thick section of permeable LCA is present in Reveille Valley, so inflow was highly sensitive to the constant-head altitude. Inflow through the Reveille Valley constant-head boundary did not noticeably improve hydraulic heads or ground-water discharge residuals in the northern areas so this group of constant-head cells was removed from the model.

The southern Railroad Valley constant-headboundary group (fig. 16) consisted of 4 cells in layer 1 . Several boreholes are present in this area, and the water-level-data qualities vary greatly. As a result, determining predevelopment ground-water conditions was difficult. Simulations including a constant-head boundary at southern Railroad Valley resulted in decreased discharge at Penoyer Valley. Flow out of the model at southern Railroad Valley resulted from simulated hydraulic heads being higher than observed water levels in the three wells in this area. Simulation problems in this area could be the result of hydrogeologic conceptual model uncertainties, not knowing accurate hydraulic gradients, and not knowing if southern Railroad and Penoyer Valleys are actually part of the simulated flow system. These constanthead cells were removed from the model.

\section{Definition of Discharge Areas}

Discharge areas in the DVRFS flow model were initially defined using one parameter for each drain in the uppermost layer. These parameters are defined as conductance. During the calibration process it became apparent that discharge from bedrock units was not being adequately simulated. Discharge from layer 1 drains was insufficient to match observed discharge rates and disproportionately intercepted water from shallower flow paths. To more appropriately simulate discharge from the deep regional ground-water flow paths, drains were moved to deeper model layers. The drain cells selected to represent this deeper component of flow were selected based on relative temperatures of discharging spring water. Warm-water springs are considered to represent deep ground-water flow. The model layer for these drains was selected based on the uppermost occurrence of the LCA. If no LCA was present in the selected model cell, the drain was placed in layer 10. Drains discharging from layer 1 are denoted by parameter names starting with a " $G$ " and from deeper than layer 1 with an "S" (table 12). Conductance values and composite scaled sensitivities (equation 2) for all drain parameters are provided in table 12 .

\section{Definition of Recharge Areas}

Recharge in the DVRFS flow model was initially defined using one parameter that varied the net inflow of ground water by a multiplicative factor between 0 and 1 for the entire model domain. The initial CSS value for this parameter was high, generally within the top five most sensitive parameters. Parameter estimation for this recharge parameter resulted in a value of 0.20 , indicating that the total recharge provided by Hevesi and others (2002) potentially was overestimated by a factor of four. As previously stated, this overestimation is believed to result from INFIL model simplifications and not accounting for processes occurring between the root zone and the water table.

During many of the early model runs, the consistently high CSS value for the recharge multiplier suggested that adequate observations existed to describe recharge using additional model parameters. Given INFIL limitations, it was, therefore, assumed that the materials at the water table were reasonable indicators of materials between the water table and land surface (excluding soils). Consequently, the major rock types occurring at the water table were used to define additional recharge parameters. Parameters were defined as multiplicative factors for recharge occurring on each major rock type including basin fill, volcanic, clastic, crystalline, and carbonate rock types (fig. 19 and table 7).

Parameters defining recharge on the carbonate rocks contributed the largest volumes of water to the ground-water flow system. High recharge rates on the Spring Mountains were necessary to properly simulate discharge in Pahrump Valley, Shoshone/Tecopa basins, Amargosa Valley, and Indian Springs (fig. 1).

Carbonate rocks in the northeastern part of the model, however, did not require as much recharge to simulate observed water levels and flows. Ultimately, three recharge parameters were defined for recharge on carbonate rocks in the Spring Mountains (simulated mean recharge of about $24 \mathrm{~mm} / \mathrm{yr}$ ) and in the northeastern (simulated mean recharge of about $6 \mathrm{~mm} / \mathrm{yr}$ ) and central/western (simulated mean recharge of about 
Table 12. Drain parameter values and composite scaled sensitivities

\begin{tabular}{|c|c|c|}
\hline Parameter name & $\begin{array}{l}\text { Conductance, in } \\
\text { meters squared } \\
\text { per day }\end{array}$ & $\begin{array}{l}\text { Composite } \\
\text { scaled } \\
\text { sensitivity }\end{array}$ \\
\hline G-AM-AMFLT & 10 & 0.224 \\
\hline G-AM-CARSL & 100 & 0.149 \\
\hline G-AM-CENTR & 100 & 0.675 \\
\hline S-AM-CENTR & 10 & $1.56 \times 10^{-2}$ \\
\hline S-AM-UPDRN & 100 & 0.205 \\
\hline G-AM-NORTH & 100 & 0.239 \\
\hline S-AM-NORTH & 10 & $6.00 \times 10^{-2}$ \\
\hline G-AM-SOUTH & 1,000 & 0.347 \\
\hline S-AM-SOUTH & 10 & $4.39 \times 10^{-3}$ \\
\hline G-CHICAGOV & 100 & 0.196 \\
\hline G-CORNCREK & 100,000 & $1.61 \times 10^{-4}$ \\
\hline G-DV-BADWT & 1,000 & $7.29 \times 10^{-3}$ \\
\hline G-DV-CONFI & 1,000 & $1.24 \times 10^{-2}$ \\
\hline G-DV-COTTN & 1,000 & $1.10 \times 10^{-2}$ \\
\hline G-DV-FRNFN & 1,000 & $7.29 \times 10^{-4}$ \\
\hline G-DV-MESQU & 1,000 & $3.35 \times 10^{-3}$ \\
\hline G-DV-MIDDL & 1,000 & $5.93 \times 10^{-4}$ \\
\hline G-DV-MORMN & 1,000 & $5.51 \times 10^{-3}$ \\
\hline S-DV-NEVAR & 10,000 & $2.69 \times 10^{-4}$ \\
\hline G-DV-SARAT & 1,000 & $2.18 \times 10^{-2}$ \\
\hline S-DV-SARAT & 1,000 & 0 \\
\hline S-DV-TEXAS & 100 & 0.298 \\
\hline S-DV-TRVRT & 10,000 & $1.68 \times 10^{-4}$ \\
\hline G-DV-WESTF & 1,000 & $2.35 \times 10^{-3}$ \\
\hline G-FRANKWEL & 100 & $5.28 \times 10^{-2}$ \\
\hline G-FRNKLK-E & 100 & $6.74 \times 10^{-2}$ \\
\hline G-FRNKLK-N & 100 & 0.186 \\
\hline G-FRNKLK-S & 100 & $1.38 \times 10^{-2}$ \\
\hline S-GRAPE-SC & 10 & $2.50 \times 10^{-2}$ \\
\hline S-GRAPE-SP & 10 & 0.154 \\
\hline G-INDIANSP & 100 & $2.93 \times 10^{-2}$ \\
\hline S-INDIANSP & 100 & $2.40 \times 10^{-2}$ \\
\hline G-OV-BEATY & 100 & 0.318 \\
\hline S-OV-BEATY & 10 & $9.10 \times 10^{-5}$ \\
\hline G-OV-COFFR & 100 & 0.505 \\
\hline S-OV-COFFR & 10 & $6.54 \times 10^{-2}$ \\
\hline G-OV-OASIS & 100 & 0.185 \\
\hline S-OV-OASIS & 10 & $3.40 \times 10^{-2}$ \\
\hline G-OV-SPRDL & 100 & 0.334 \\
\hline S-OV-SPRDL & 10 & $5.27 \times 10^{-2}$ \\
\hline G-PAH-BENT & 1,000 & $9.54 \times 10^{-2}$ \\
\hline G-PAH-MANS & 1,000 & $2.73 \times 10^{-2}$ \\
\hline G-PENOYERV & 10,000 & $6.07 \times 10^{-3}$ \\
\hline G-SARCO-CH & 100 & 0.174 \\
\hline G-SARCO-NE & 100 & 0.261 \\
\hline G-SARCO-SW & 100 & 0.102 \\
\hline G-SHOSH-N & 100 & $8.30 \times 10^{-2}$ \\
\hline G-SHOSH-S & 100 & 0.202 \\
\hline
\end{tabular}

Table 12. Drain parameter values and composite scaled sensitivities-Continued

\begin{tabular}{lcc}
\hline Parameter name & $\begin{array}{c}\text { Conductance, in } \\
\text { meters squared } \\
\text { per day }\end{array}$ & $\begin{array}{c}\text { Composite } \\
\text { scaled } \\
\text { sensitivity }\end{array}$ \\
\hline S-SHOSH-S & 10 & $5.95 \times 10^{-3}$ \\
G-STEWRT-P & 1,000 & $6.32 \times 10^{-2}$ \\
G-STEWRT-V & 1,000 & $1.09 \times 10^{-2}$ \\
G-TC-AMCAN & 10 & $5.93 \times 10^{-2}$ \\
G-TC-CHRNC & 10 & $1.27 \times 10^{-2}$ \\
G-TC-RESTS & 1,000 & 0.190 \\
S-TC-RESTS & 10 & 0 \\
G-TC-SPERY & 10 & $7.33 \times 10^{-2}$ \\
G-TC-TECOP & 1,000 & $1.59 \times 10^{-2}$ \\
\hline
\end{tabular}

$2 \mathrm{~mm} / \mathrm{yr}$ ) parts of the model domain. In the final calibrated model, recharge on the Spring Mountains was 55 percent of the net infiltration array, whereas recharge on the northeastern and central/western areas was about 25 percent and 12 percent of the net infiltration array provided by Hevesi and others (2002), respectively (table 13). This reduction of net infiltration seems reasonable considering that the composition of the carbonate rocks is quite variable among these three regions of the flow model.

Parameters defining recharge on volcanic rock areas also were further subdivided. This was done to determine if the undifferentiated volcanic (VU) rocks had less actual recharge than the INFIL model suggests. The rationale was that the VU rocks are significantly older than most of the volcanic rocks in the Timber Mountain and Pahute Mesa areas and potentially had altered zones that could impede infiltrating waters. Ultimately, recharge parameters were defined for the Timber Mountain and Pahute Mesa volcanic units (RCH_zone2a) and for all other volcanic units (RCH_zone2b) (fig. 19). In the final calibrated model, recharge on the volcanic rocks was left at approximately 100 percent of the original estimates (table 13). This high level of agreement is reasonable considering that the INFIL model was originally developed and tested on the volcanic rocks of Yucca Mountain (Hevesi and others, 2002).

Recharge rates equal to net infiltration rates applied to confining units with smaller values of hydraulic conductivity $(\mathrm{K})$ in the DVRFS flow model typically resulted in hydraulic-head mounding. This inconsistency likely resulted from an overestimation of natural infiltration in the INFIL model because rock units were assigned permeabilities that were larger 
Table 13. Recharge parameter descriptions, values, and composite scaled sensitivities

\begin{tabular}{lllc}
\hline $\begin{array}{c}\text { Parameter } \\
\text { name }\end{array}$ & \multicolumn{1}{c}{ Description } & $\begin{array}{c}\text { Parameter } \\
\text { value }\end{array}$ & $\begin{array}{c}\text { Composite } \\
\text { scaled } \\
\text { sensitivity }\end{array}$ \\
\hline RCH_zone1 & Basin-fill units & 0.0 & $3.68 \times 10^{-2}$ \\
RCH_zone2a & Volcanic units-Timber Mountain and Pahute Mesa area & 1.0 & 2.31 \\
RCH_zone2b & Volcanic units-All other & 1.0 & 2.15 \\
RCH_zone3a & Crystalline units-Upper 300 meters of TJi \& pCgm & 0.005 & $2.74 \times 10^{-3}$ \\
RCH_zone3b & Clastic units-Upper 300 meters of UCCU & 0.05 & $1.06 \times 10^{-3}$ \\
RCH_zone3c & Clastic units-Upper 300 meters of LCCU \& Mvs & 0.01 & 2.91 \\
RCH_zone3d & Clastic units-LCCU thrusts & 0.05 & $6.02 \times 10^{-2}$ \\
RCH_zone4a & Crystalline units-TJi \& pCgm deeper than 300 meters & 0.001 & $6.75 \times 10^{-2}$ \\
RCH_zone4b & Clastic units-UCCU deeper than 300 meters & 0.01 & 16.8 \\
RCH_zone4c & Clastic units-LCCU deeper than 300 meters & 0.00003 & 1.21 \\
RCH_zone5a & Carbonate units in central/western area & 0.12 & 0.174 \\
RCH_zone5b & Carbonate units in Spring Mountains area & 0.55 & 2.01 \\
RCH_zone5c & Carbonate units in northeastern area & 0.25 & 1.66 \\
\hline
\end{tabular}

than reasonable. This may result from infiltrating water moving past the root zone but being diverted before reaching the water table by smaller K rock units. Bedinger and others (1989) account for a similar situation in metamorphic and crystalline rocks in the Death Valley region. They suggest that the hydraulic conductivity of metamorphic and crystalline rocks at depths less than $300 \mathrm{~m}$ below land surface is significantly larger than rocks at depths greater than $300 \mathrm{~m}$. To test this interpretation in the DVRFS flow model, the HFM was modified to represent confining units that occur within $300 \mathrm{~m}$ of land surface ("upper" units) and those that occur at depths more than $300 \mathrm{~m}$ below land surface ("lower" units). Then, recharge parameters were defined by grouping recharge rates occurring on "upper" and "lower" confining units. Recharge parameters with this configuration allowed net infiltration to be reduced slightly more on smaller K "lower" confining units. However, the effective recharge on all of the clastic and crystalline rocks was nearly zero (table 13). Only slight amounts of recharge were required to maintain the ground-water mounds occurring in these areas.

\section{Variations in Interpretation of Hydrogeologic Framework}

Four general types of changes were made to the hydrogeologic conceptual model during calibration. These include: (1) splitting major rock types into more detailed and complex hydrogeologic units, (2) subdividing hydrogeologic units into spatial regions or zones, (3) adding vertical anisotropy parameters, and (4) differentiating hydrogeologic-unit parameters based on depth. Initially, the hydrogeologic conceptual model used in the DVRFS flow model was simplified to represent four major rock types including confining units (K1), carbonate rocks (K2), volcanic rocks (K3), and basin-fill units (K4). These rock types were considered homogeneous and isotropic and were represented by K parameters. Then, the hydrogeologic framework representation was evaluated by calculating hydraulic heads and ground-water discharges using MODFLOW-2000. Sensitivities were calculated for parameters in each conceptual model representation. Parameters with high CSS values were further divided. For example, the carbonate rock K parameter was subdivided first because of its high sensitivity. This logic was followed for all K parameters that had high enough sensitivities. Model fit generally improved as $\mathrm{K}$ parameters were subdivided into more specific hydrogeologic units. Some parameters created during this process had low CSS values. The assigned value for these parameters did not influence calculated heads and flows significantly; however, defining these parameters helped in the overall understanding of how the ground-water flow system functions. 


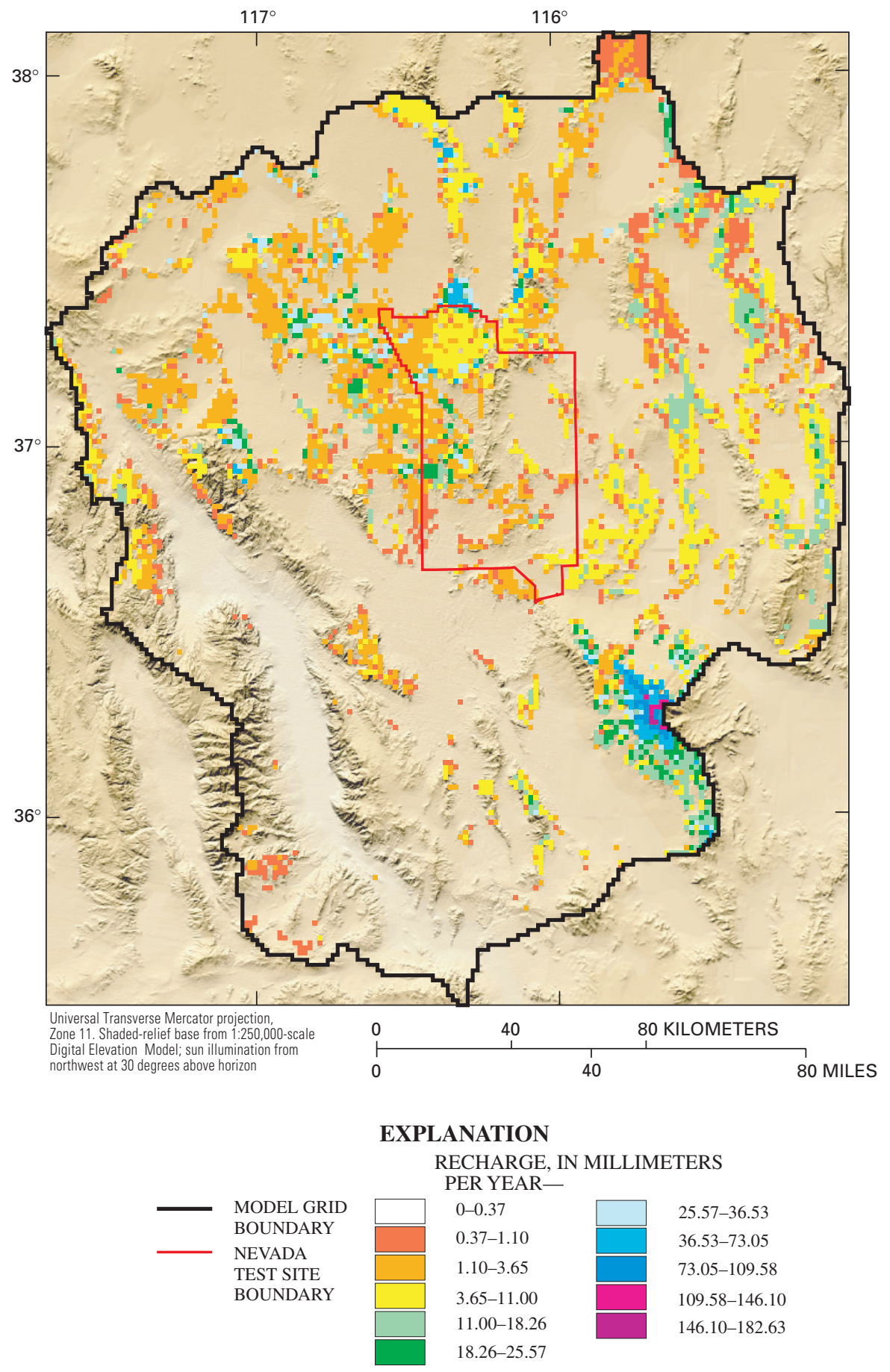

Figure 21. Recharge simulated in the Death Valley regional flow system model.

\section{Confining Units}

The confining-unit rock type consists of crystalline and clastic rocks. Crystalline hydrogeologic units include Precambrian granites and metamorphic rocks (pCgm) and Tertiary-Jurassic intrusives (TJi). Clastic hydrogeologic units consist of the upper clastic confining unit (UCCU), lower clastic confining unit (LCCU), and the Mesozoic volcaniclastic and sedimentary rocks (Mvs).

Initially, all rocks interpreted to be confining units were grouped into one $\mathrm{K}$ parameter. The sensitivity of this parameter was lower than the three other major rock-type parameters. This may be a result of 
there being smaller volumes of water flowing through these smaller K rocks and few hydraulic-head observations present in these hydrogeologic units. This coarse representation of the hydrogeologic framework resulted in a simulated head distribution that generally matched the location of hydraulic gradients. The simulated hydraulic gradients, however, were in many places not as well defined because many smaller K rocks were lumped together. When various types of smaller $\mathrm{K}$ rocks were differentiated into different $\mathrm{K}$ parameters (for example, crystalline and clastic units) a closer match to large hydraulic gradients resulted.

Smaller K rocks also control the direction and magnitude of dominant regional ground-water flow paths. In many cases, deeply buried, crystalline rocks form the core of mountain ranges in the region. These rocks are generally barriers to interbasin flow and, in some areas, affect flow to discharge areas. Also, clastic rocks occur higher in the section than crystalline rocks and can also form mountain-range blocks to regional flow, such as in the Funeral Mountains and Sheep Range (fig. 11). In some cases, the further differentiation of these clastic and crystalline rocks improved not only model fit to hydraulic heads but also model fit to flows out of the model at important regional ground-water discharge areas.

Zone arrays and parameters also were used to refine the distribution of $\mathrm{K}$ parameters for clastic and crystalline rocks (figs. 22, 23, 24, and 25). Hydraulicconductivity parameter zones were delineated to isolate largely continuous areas of a hydrogeologic unit or to isolate areas with potentially similar structural deformation.

The hydrogeologic reasoning supporting this is that isolated or relatively continuous sections of rocks could be compositionally distinct or have undergone similar structural deformation. Also, different forms of structural deformation tend to affect the hydraulic properties of ductile and brittle rocks differently. For example, shear-zone deformation tends to reduce the hydraulic conductivity of ductile rocks, such as the clastic units, but may increase the hydraulic conductivity of brittle rocks, such as the crystalline units. Extensional deformation tends to increase the hydraulic conductivity of these units by creating or enhancing secondary permeability.

Crystalline and clastic K parameters defined by spatial zones had varying degrees of impact on the flow model. For example, the large hydraulic gradient from the Grapevine Mountains into Death Valley was simulated more accurately when the LCCU K parameter in the Grapevine Mountains was zoned along faults bounding the Grapevine Mountains (fig. 22). By better defining this large hydraulic gradient, more reasonable volumes of water flowing through the Grapevine Mountains to discharge points in northern Death Valley were simulated. Similarly, LCCU parameters defined by zones in areas coincident with structural basins also controlled intrabasin and interbasin flow to discharge areas (fig. 22).

Although the $\mathrm{pCgm}$ and LCCU parameters generally have smaller $\mathrm{K}$, larger $\mathrm{K}$ values were required to allow ground water to flow from Pahrump Valley to Shoshone and Tecopa Valleys. CSS values for the $\mathrm{pCgm} \mathrm{K}$ parameters were generally low, suggesting that there were insufficient data supporting these parameters. Also, $\mathrm{K}$ for most $\mathrm{pCgm}$ parameters was small, which would limit the flow through this unit and tend to lower model sensitivity. Even though model sensitivity was generally low for the $\mathrm{pCgm}$ and TJi K parameters, they play an important role in directing interbasin and intrabasin flow (figs. 23 and 24). A summary of how confining unit parameters were subdivided is presented in table 14. A description of LCCU, pCgm, and TJi parameters is presented in table 15, table 16, and table 17.

\section{Carbonate Rocks}

The carbonate-rock group consists of the upper carbonate aquifer (UCA) (fig. 26) and the lower carbonate aquifer (LCA) (fig. 27). These hydrogeologic units were initially grouped into one $\mathrm{K}$ parameter, and the CSS value was more than four times greater than the parameters defining the other major rock types. This high sensitivity was expected because the LCA is the most extensive and prolific aquifer in the region. Because of this high sensitivity, the $\mathrm{K}$ parameter defining carbonate rocks was subdivided into two K parameters for the UCA and LCA hydrogeologic units. The LCA remained highly sensitive. As a result, the four HFM model units describing LCA rocks contained in thrust sheets were then separated into individual $\mathrm{K}$ parameters. On a regional scale, the $\mathrm{K}$ parameters defining LCA thrust units are relatively unimportant; however, these K parameters can influence flow patterns on a local scale. For example, discharges at Nevares, Texas, and Travertine Springs were strongly influenced by the K of the LCA_T1 parameter (fig. 26). Because the LCA hydrogeologic 


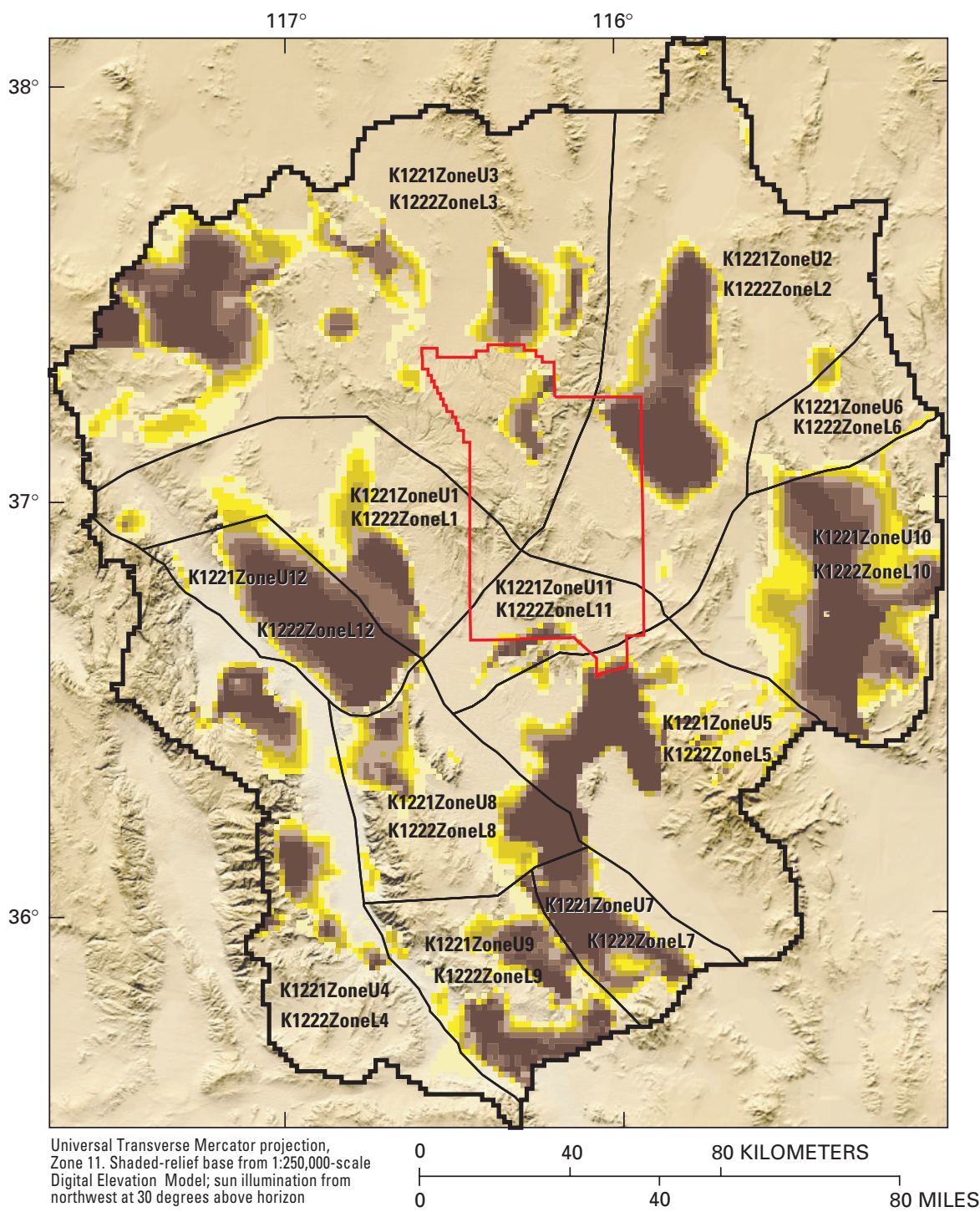

EXPLANATION

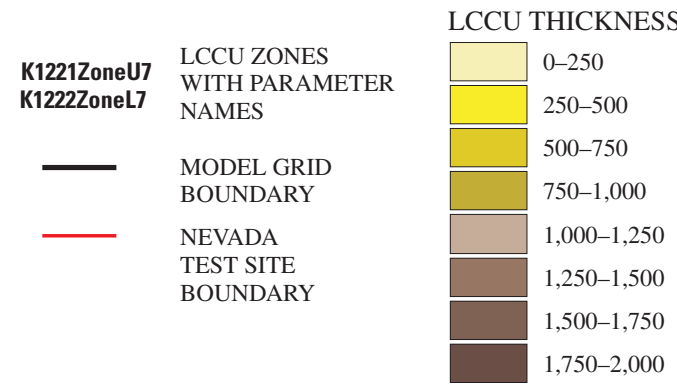

Figure 22. Definition of lower clastic confining unit (LCCU) hydraulic-conductivity zone parameters and unit thickness. 


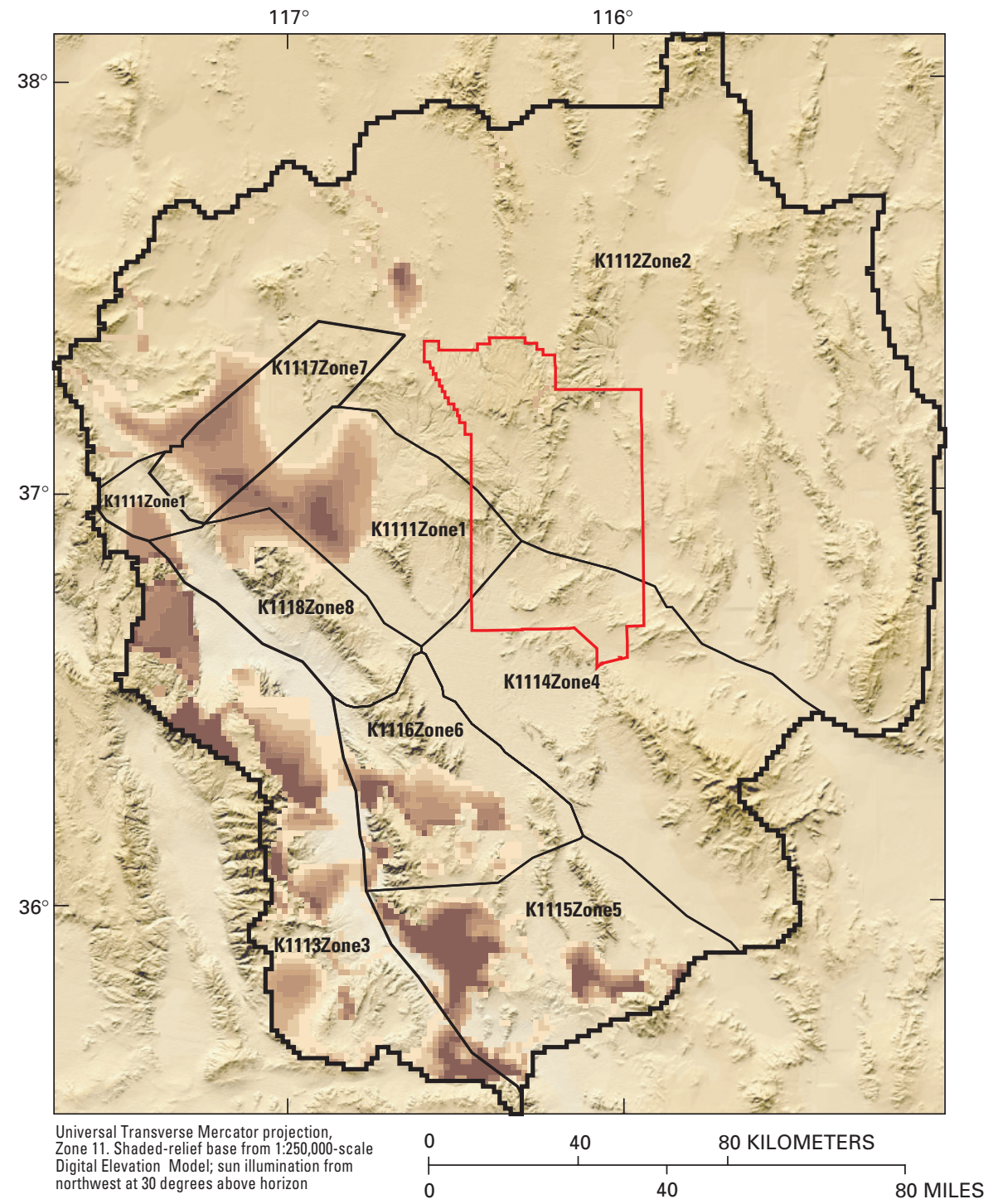

\section{EXPLANATION}

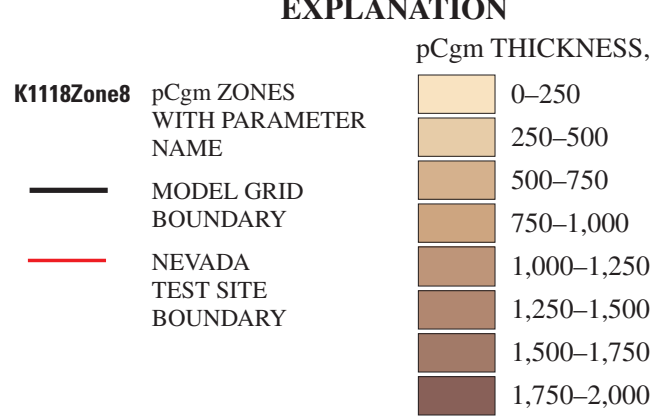

Figure 23. Definition of Precambrian granites and metamorphic rocks (pCgm) hydraulic-conductivity zone parameters and unit thickness. 


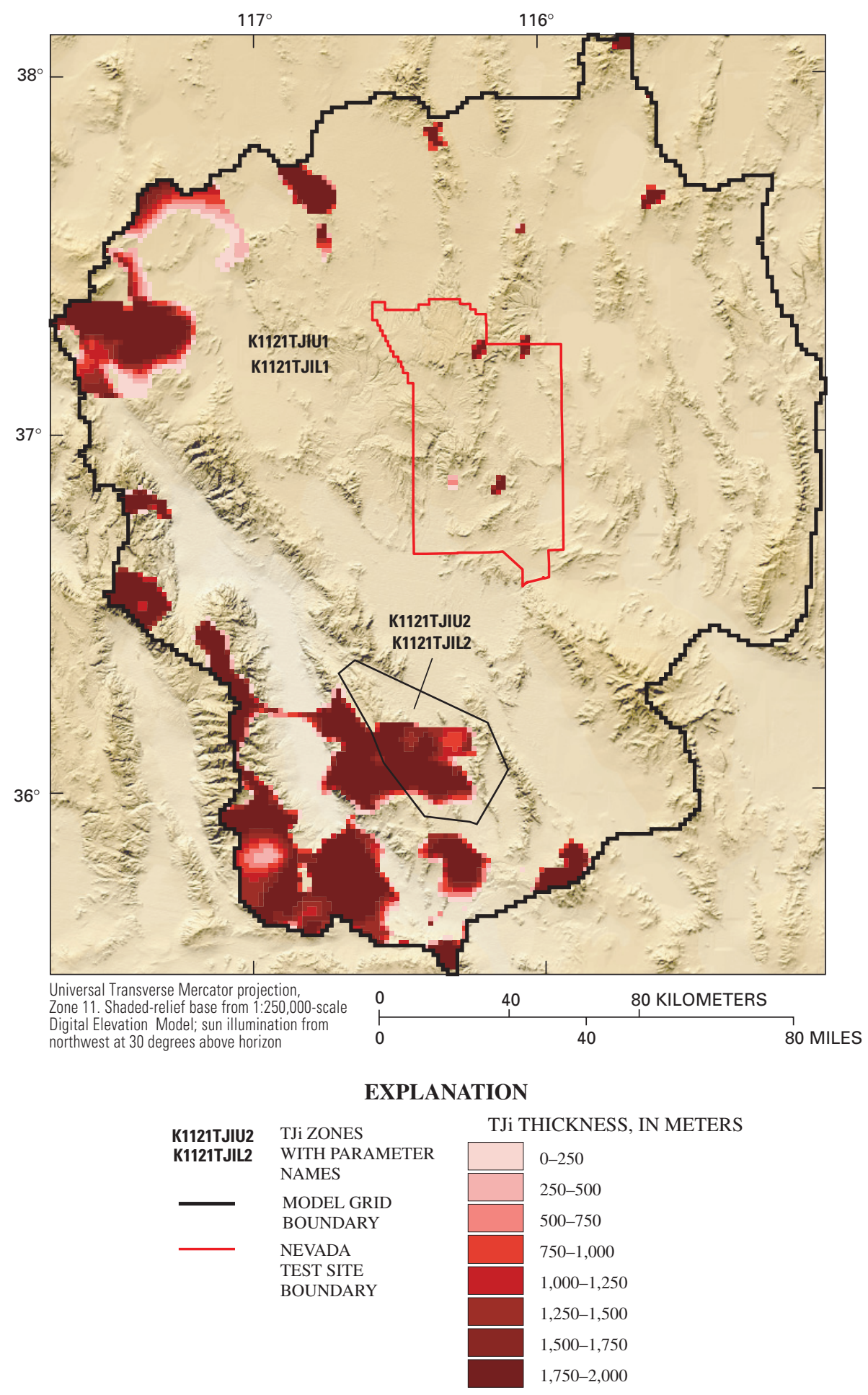

Figure 24. Definition of Tertiary-Jurassic intrusives (TJi) hydraulic-conductivity zone parameters and unit thickness. 


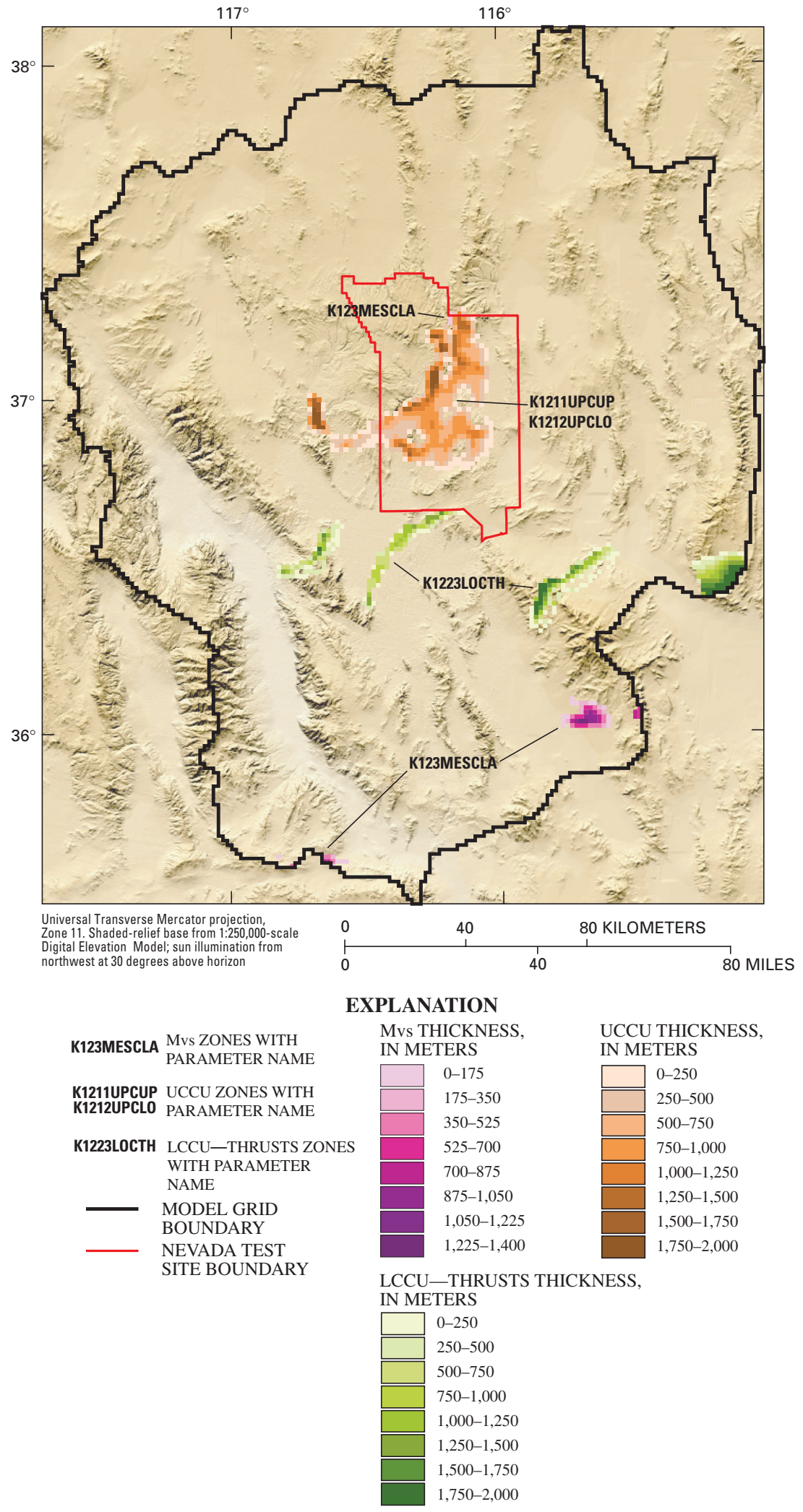

Figure 25. Definition of hydraulic-conductivity parameters and unit thickness for Mesozoic volcaniclastic and sedimentary rocks (Mvs), upper clastic confining unit (UCCU), and lower clastic confining unit (LCCU) thrust-fault units. 
Table 14. Hierarchical structure of hydrogeologic unit parameters and major events guiding parameter delineation

\begin{tabular}{|c|c|c|c|c|c|}
\hline $\begin{array}{c}\text { First order } \\
\text { parameters }{ }^{1}\end{array}$ & $\begin{array}{l}\text { Second order } \\
\text { parameters }^{2}\end{array}$ & $\begin{array}{l}\text { Third order } \\
\text { parameters }^{3}\end{array}$ & $\begin{array}{l}\text { Fourth order } \\
\text { parameters }\end{array}$ & $\begin{array}{c}\text { Fifth order } \\
\text { parameters }{ }^{5}\end{array}$ & $\begin{array}{c}\text { Sixth order } \\
\text { parameters }\end{array}$ \\
\hline \multirow[t]{7}{*}{$\begin{array}{l}\text { K1 Confining units - } \\
\text { crystalline and } \\
\text { clastic rocks }\end{array}$} & $\begin{array}{l}\text { K11 Crystalline } \\
\text { rocks }\end{array}$ & $\begin{array}{l}\text { K111 Precambrian } \\
\text { granites and meta- } \\
\text { morphic rocks } \\
(\mathrm{pCgm})\end{array}$ & $\begin{array}{l}\text { Zones to determine } \\
\text { pCgm role in } \\
\text { Death Valley large } \\
\text { hydraulic gradient }\end{array}$ & $\begin{array}{l}\text { Zones to determine } \\
\text { pCgm role at major } \\
\text { discharge areas }\end{array}$ & \\
\hline & & $\begin{array}{l}\text { K112 Tertiary- } \\
\text { Jurassic intrusives } \\
\text { (TJi) }\end{array}$ & $\begin{array}{l}\text { Zone to test extent of } \\
\text { TJi in Greenwater } \\
\text { Range and role } \\
\text { in discharge at } \\
\text { Franklin Lake }\end{array}$ & & \\
\hline & K12 Clastic rocks & $\begin{array}{l}\text { K121 Upper clastic } \\
\text { confining unit } \\
\text { (UCCU) }\end{array}$ & & & \\
\hline & & $\begin{array}{l}\text { K122 Lower clastic } \\
\text { confining units } \\
\text { (LCCU, } \\
\text { LCCU_GP, } \\
\text { LCCU_T1, } \\
\text { LCCU_T2) }\end{array}$ & $\begin{array}{l}\text { K1221 Lower clastic } \\
\text { confining unit } \\
\text { (LCCU) - } \\
\text { Depth less than } \\
300 \text { meters below } \\
\text { land surface }\end{array}$ & $\begin{array}{l}\text { Zones based on large } \\
\text { hydraulic gradient } \\
\text { areas and regions } \\
\text { with similar struc- } \\
\text { tural deformation }\end{array}$ & $\begin{array}{l}\text { Zones based on } \\
\text { isolated sections } \\
\text { and areas poten- } \\
\text { tially impacting } \\
\text { flow-system } \\
\text { discharge }\end{array}$ \\
\hline & & & $\begin{array}{l}\text { K1222 Lower clastic } \\
\text { confining unit } \\
\text { (LCCU) - } \\
\text { Depth greater than } \\
300 \text { meters below } \\
\text { land surface }\end{array}$ & $\begin{array}{l}\text { Zones based on large } \\
\text { hydraulic gradient } \\
\text { areas and regions } \\
\text { with similar struc- } \\
\text { tural deformation }\end{array}$ & $\begin{array}{l}\text { Zones based on } \\
\text { isolated sections } \\
\text { and areas poten- } \\
\text { tially impacting } \\
\text { flow-system } \\
\text { discharge }\end{array}$ \\
\hline & & & $\begin{array}{l}\text { K1223 Lower clastic } \\
\text { confining unit } \\
\text { thrusts } \\
\text { (LCCU_GP, } \\
\text { LCCU_T1, } \\
\text { LCCU_T2) }\end{array}$ & & \\
\hline & & $\begin{array}{l}\text { K123 Mesozoic } \\
\text { volcaniclastic and } \\
\text { sedimentary rocks } \\
\text { (Mvs, Mvs_KS, } \\
\text { Mvs_LC) }\end{array}$ & & & \\
\hline \multirow[t]{4}{*}{ K2 Carbonate rocks } & $\begin{array}{l}\text { K21 Lower } \\
\text { carbonate aquifer } \\
\text { (LCA,LCA_GP, } \\
\text { LCA_LC, } \\
\text { LCA_T1, } \\
\text { LCA_T2) }\end{array}$ & $\begin{array}{l}\text { K211 Lower } \\
\text { carbonate aquifer } \\
\text { (LCA) }\end{array}$ & $\begin{array}{l}\text { Major structural } \\
\text { zones defined by } \\
\text { Carr (1990) and } \\
\text { Faunt (1997). }\end{array}$ & $\begin{array}{l}\text { Refinement of struc- } \\
\text { tural zones based } \\
\text { on hydrologic data } \\
\text { and more detailed } \\
\text { geologic data }\end{array}$ & $\begin{array}{l}\text { Zones to test uncer- } \\
\text { tainty in hydrogeo- } \\
\text { logic framework } \\
\text { model and identify } \\
\text { areas critical to } \\
\text { flow-system } \\
\text { discharge }\end{array}$ \\
\hline & & $\begin{array}{l}\text { K212 Lower } \\
\text { carbonate aquifer } \\
\text { thrusts (LCA_GP, } \\
\text { LCA_LC, } \\
\text { LCA_T1, } \\
\text { LCA_T2) }\end{array}$ & $\begin{array}{l}\text { K2121 Lower } \\
\text { carbonate aquifer } \\
\text { T1 thrust } \\
\text { (LCA_T1) }\end{array}$ & & \\
\hline & & & $\begin{array}{l}\text { K2122 Lower } \\
\text { carbonate aquifer } \\
\text { T2 thrust } \\
\text { (LCA_T2) }\end{array}$ & & \\
\hline & & & $\begin{array}{l}\text { K2123 Lower } \\
\text { carbonate aquifer } \\
\text { Gass Peak thrust } \\
\text { (LCA_GP) }\end{array}$ & & \\
\hline
\end{tabular}


Table 14. Hierarchical structure of hydrogeologic unit parameters and major events guiding parameter delineation—Continued

\begin{tabular}{|c|c|c|c|c|c|c|}
\hline & $\begin{array}{c}\text { First order } \\
\text { parameters }\end{array}$ & $\begin{array}{l}\text { Second order } \\
\text { parameters }\end{array}$ & $\begin{array}{l}\text { Third order } \\
\text { parameters }\end{array}$ & $\begin{array}{l}\text { Fourth order } \\
\text { parameters }\end{array}$ & $\begin{array}{c}\text { Fifth order } \\
\text { parameters }\end{array}$ & $\begin{array}{c}\text { Sixth order } \\
\text { parameters }\end{array}$ \\
\hline & & & & $\begin{array}{l}\text { K2124 Lower } \\
\text { carbonate aquifer } \\
\text { Lee Canyon thrust } \\
\text { (LCA_LC) }\end{array}$ & & \\
\hline & & $\begin{array}{l}\text { K22 Upper carbonate } \\
\text { aquifer (UCA) }\end{array}$ & & & & \\
\hline \multirow[t]{9}{*}{$\mathrm{K} 3$} & Volcanic rocks & $\begin{array}{l}\text { K31 Undifferentiated } \\
\text { volcanic rocks } \\
\text { outside of Nevada } \\
\text { Test Site (VU) }\end{array}$ & $\begin{array}{l}\text { Zones based on major } \\
\text { volcanic regions }\end{array}$ & $\begin{array}{l}\text { Zones based on } \\
\text { volcanic centers }\end{array}$ & & \\
\hline & & $\begin{array}{l}\text { K32 Southern } \\
\text { Nevada Test } \\
\text { Site/Yucca Moun- } \\
\text { tain volcanic rocks }\end{array}$ & $\begin{array}{l}\text { K321 Volcanic } \\
\text { aquifer (VA) }\end{array}$ & & & \\
\hline & & & $\begin{array}{l}\text { K322 Volcanic } \\
\text { confining unit } \\
\text { (VCU) }\end{array}$ & & & \\
\hline & & $\begin{array}{l}\text { K33 Timber Moun- } \\
\text { tain caldera } \\
\text { complex/Pahute } \\
\text { Mesa volcanic } \\
\text { rocks }\end{array}$ & $\begin{array}{l}\text { K331 Belted Range } \\
\text { aquifer (TBA) }\end{array}$ & $\begin{array}{l}\text { Vertical anisotropy } \\
\text { parameter added }\end{array}$ & & \\
\hline & & & $\begin{array}{l}\text { K332 Basal } \\
\text { confining unit } \\
\text { (TBCU) } \\
\text { (nonwelded tuff) }\end{array}$ & $\begin{array}{l}\text { Vertical anisotropy } \\
\text { parameter added }\end{array}$ & & \\
\hline & & & $\begin{array}{l}\text { K333 Basal aquifer } \\
\text { (TBQ) (welded } \\
\text { tuff) }\end{array}$ & $\begin{array}{l}\text { Vertical anisotropy } \\
\text { parameter added }\end{array}$ & & \\
\hline & & & $\begin{array}{l}\text { K334 Bullfrog } \\
\text { confining unit } \\
\text { (TCB) }\end{array}$ & $\begin{array}{l}\text { Vertical anisotropy } \\
\text { parameter added }\end{array}$ & & \\
\hline & & & $\begin{array}{l}\text { K335 Paint- } \\
\text { brush/Calico Hills } \\
\text { tuff cone (TC) }\end{array}$ & $\begin{array}{l}\text { Vertical anisotropy } \\
\text { parameter added }\end{array}$ & & \\
\hline & & & $\begin{array}{l}\text { K336 Timber Moun- } \\
\text { tain aquifer (TMA) }\end{array}$ & $\begin{array}{l}\text { Vertical anisotropy } \\
\text { parameter added }\end{array}$ & & \\
\hline \multirow[t]{3}{*}{ K4 } & Basin-fill units & $\begin{array}{l}\text { K41 Quaternary- } \\
\text { Tertiary valley-fill } \\
\text { alluvium (QTal) }\end{array}$ & $\begin{array}{l}\text { Zones for basins with } \\
\text { similar deposi- } \\
\text { tional environ- } \\
\text { ments }\end{array}$ & $\begin{array}{l}\text { Zones for major } \\
\text { basins }\end{array}$ & $\begin{array}{l}\text { Zones to identify } \\
\text { areas critical to } \\
\text { flow system } \\
\text { discharge }\end{array}$ & \\
\hline & & $\begin{array}{c}\text { K42 Quaternary- } \\
\text { Tertiary playa } \\
\text { deposits (QTp) }\end{array}$ & $\begin{array}{l}\text { Zones for playas with } \\
\text { similar deposi- } \\
\text { tional environ- } \\
\text { ments - Death } \\
\text { Valley, Amargosa } \\
\text { Valley, all others }\end{array}$ & $\begin{array}{c}\text { Zones for major } \\
\text { playas within } \\
\text { Death Valley }\end{array}$ & & \\
\hline & & $\begin{array}{l}\text { K43 Tertiary sedi- } \\
\text { ments/Death } \\
\text { Valley } \\
\text { section(TSDVS) }\end{array}$ & $\begin{array}{l}\text { Zones inside and } \\
\text { outside Death } \\
\text { Valley }\end{array}$ & $\begin{array}{l}\text { Zones based on } \\
\text { discharge areas } \\
\text { (northern and } \\
\text { central zones } \\
\text { within Death } \\
\text { Valley) }\end{array}$ & $\begin{array}{l}\text { Zones to test impor- } \\
\text { tance of TSDVS } \\
\text { outside of Death } \\
\text { Valley }\end{array}$ & \\
\hline
\end{tabular}

\footnotetext{
${ }^{1}$ Parameters subdivided by major rock types.

${ }^{2}$ Parameters subdivided by major hydrogeologic units.

${ }^{3}$ Parameters subdivided by major hydrogeologic units and zones with similar characteristics.

${ }^{4}$ Parameters subdivided by zones with similar characteristics, depth greater or less than 300 meters, thrust-faulted hydrogeologic units, and vertical anisotropy.

${ }^{5}$ Parameters subdivided by zones with similar characteristics.
} 
Table 15. Description of lower clastic confining unit (LCCU) horizontal hydraulic-conductivity parameters

\begin{tabular}{|c|c|}
\hline Parameter name & Description \\
\hline $\begin{array}{l}\text { K1221LOCU1 and } \\
\text { K1221LOCL1 }\end{array}$ & $\begin{array}{l}\text { This zone includes LCCU rocks in the Bare Mountain area and to a lesser extent in the Sarcobatus Flats } \\
\text { area. This zone was delineated to differentiate Bare Mountain LCCU rocks from rocks in the Grape- } \\
\text { vine Mountains and Bullfrog Hills. LCCU rocks in the Bare Mountain area could potentially have } \\
\text { different hydraulic properties because Bare Mountain has undergone detachment faulting and Bull- } \\
\text { frog Hills has undergone a degree of hydrothermal alteration. }\end{array}$ \\
\hline $\begin{array}{l}\text { K1221LOCU2 and } \\
\text { K1221LOCL2 }\end{array}$ & $\begin{array}{l}\text { This zone includes LCCU rocks in the Penoyer and Emigrant Valley areas. This zone was delineated to } \\
\text { evaluate whether or not the LCCU provides an effective barrier to flow out of Penoyer and Emigrant } \\
\text { Valleys into Tikaboo and Indian Springs Valleys. }\end{array}$ \\
\hline $\begin{array}{l}\text { K1221LOCU3 and } \\
\text { K1221LOCL3 }\end{array}$ & $\begin{array}{l}\text { This zone includes LCCU rocks in the northwest Walker Lane from the Slate Ridge and Lida Valley } \\
\text { area to Pahute Mesa. The geometry and extent of these rocks in the subsurface north of Pahute Mesa } \\
\text { is highly interpretive. }\end{array}$ \\
\hline $\begin{array}{l}\text { K1221LOCU4 and } \\
\text { K1221LOCL4 }\end{array}$ & $\begin{array}{l}\text { This zone includes LCCU rocks in the Inyo-Mono structural zone. The geometry and extent of these } \\
\text { rocks are highly interpretive under Death Valley and less so where they outcrop in the Panamint } \\
\text { Range. }\end{array}$ \\
\hline $\begin{array}{l}\text { K1221LOCU5 and } \\
\text { K1221LOCL5 }\end{array}$ & $\begin{array}{l}\text { This zone includes thick sections of LCCU rocks in the northwest and northeast part of the Spring } \\
\text { Mountains where they have likely undergone deformation due to thrust faulting. }\end{array}$ \\
\hline $\begin{array}{l}\text { K1221LOCU6 and } \\
\text { K1221LOCL6 }\end{array}$ & $\begin{array}{l}\text { This zone includes a small area of LCCU rocks in the vicinity of the Desert Range. Rocks in this area } \\
\text { are interpreted as being affected by the structural deformation occurring in the Pahranagat shear } \\
\text { zone. }\end{array}$ \\
\hline $\begin{array}{l}\text { K1221LOCU7 and } \\
\text { K1221LOCL7 }\end{array}$ & $\begin{array}{l}\text { This zone includes a thick section of LCCU rocks interpreted as extending beneath Pahrump Valley. } \\
\text { Rocks in this zone are believed to be affected by extensional faulting that caused the development of } \\
\text { Pahrump Valley. }\end{array}$ \\
\hline $\begin{array}{l}\text { K1221LOCU8 and } \\
\text { K1221LOCL8 }\end{array}$ & $\begin{array}{l}\text { This zone includes a relatively thick section of LCCU rocks interpreted as occurring in the subsurface } \\
\text { immediately west of Death Valley Junction. The geometry, extent, and hydraulic nature of these } \\
\text { rocks are interpreted from geologic structure of the southern Funeral Mountains and the Furnace } \\
\text { Creek Fault zone. }\end{array}$ \\
\hline $\begin{array}{l}\text { K1221LOCU9 and } \\
\text { K1221LOCL9 }\end{array}$ & $\begin{array}{l}\text { This zone includes relatively shallow LCCU rocks in the Shoshone/Tecopa area. The geometry, extent, } \\
\text { and hydraulic nature of these rocks are interpreted from surface mapping. }\end{array}$ \\
\hline $\begin{array}{l}\text { K1221LOCU10 and } \\
\text { K1221LOCL10 }\end{array}$ & $\begin{array}{l}\text { This zone includes a very thick sections of LCCU rocks interpreted to occur in the vicinity of Desert } \\
\text { Dry Lake and the Sheep Range where they have likely undergone deformation due to thrust faulting } \\
\text { in the Sheep Range and shear faulting associated with the Las Vegas Valley shear zone. }\end{array}$ \\
\hline $\begin{array}{l}\text { K1221LOCU11 and } \\
\text { K1221LOCL11 }\end{array}$ & $\begin{array}{l}\text { This zone includes LCCU rocks in the Jackass Flats and Amargosa Farms areas. The geometry, extent, } \\
\text { and hydraulic nature of these rocks are interpreted from their apparent association with the Rock } \\
\text { Valley fault. }\end{array}$ \\
\hline $\begin{array}{l}\text { K1221LOCU12 and } \\
\text { K1221LOCL12 }\end{array}$ & $\begin{array}{l}\text { This zone includes a thick section of LCCU rocks in the Bullfrog Hills and the Grapevine Mountains. } \\
\text { This zone was delineated to evaluate the uncertainty of the geometry, extent, and hydraulic nature of } \\
\text { these rocks that apparently provide a very effective barrier to flow from Sarcobatus Flat to the Amar- } \\
\text { gosa Valley and from the Amargosa Valley to Death Valley. }\end{array}$ \\
\hline
\end{tabular}


Table 16. Description of Precambrian granites and metamorphic rocks (pCgm) horizontal hydraulic-conductivity parameters

\begin{tabular}{|c|c|}
\hline Parameter name & Description \\
\hline K1111PCGM1 & $\begin{array}{l}\text { This zone includes pCgm rocks in the Bare Mountain Bullfrog Hills area. The pCgm rocks in this area } \\
\text { are interpreted as providing a barrier to flow between the Sarcobatus Flat/Oasis Valley area and the } \\
\text { northwestern arm of the Amargosa Valley. They are differentiated from other pCgm rocks in the region } \\
\text { because they are exposed core complexes of detachment faulting and have potentially been altered by } \\
\text { hydrothermal processes in the Oasis Valley area. }\end{array}$ \\
\hline K1112PCGM2 & $\begin{array}{l}\text { This zone includes pCgm rocks in the northern part of the model domain. The pCgm rocks in this area } \\
\text { are interpreted as being very deep and relatively intact. }\end{array}$ \\
\hline K1113PCGM3 & $\begin{array}{l}\text { This zone includes pCgm rocks beneath Death Valley and the Panamint Range. The complexity of } \\
\text { geologic structures and the lack of subsurface data result in highly interpretive geometry and extent for } \\
\text { rocks in this zone. }\end{array}$ \\
\hline K1114PCGM4 & $\begin{array}{l}\text { This zone includes pCgm rocks in the Spring Mountains and Pahrump Valley area. The pCgm rocks in } \\
\text { this area are interpreted as being quite deep. This zone was delineated so that the hydraulic conduc- } \\
\text { tivity of pCgm rocks could be changed to be more representative of LCCU rocks that are stratigraphi- } \\
\text { cally above the pCgm rocks. }\end{array}$ \\
\hline K1115PCGM5 & $\begin{array}{l}\text { This zone includes pCgm rocks in the Tecopa/Shoshone area. The lack of subsurface data in this zone } \\
\text { suggests that the hydrogeologic framework model is highly interpretive for this unit. This zone was } \\
\text { delineative so that the hydraulic conductivity of pCgm rocks could be changed to be more representa- } \\
\text { tive of LCCU rocks that are stratigraphically above the pCgm rocks. }\end{array}$ \\
\hline K1116PCGM6 & $\begin{array}{l}\text { This zone includes pCgm rocks in the Black Mountains and the Amargosa Range. The geology of this } \\
\text { region is extremely complex and highly metamorphosed. This zone was delineated so the relative } \\
\text { uncertainty of the hydrogeologic framework model in this area could be evaluated. }\end{array}$ \\
\hline K1117PCGM7 & $\begin{array}{l}\text { This zone includes pCgm rocks in the interpreted NE/SW-trending structural zone extending from the } \\
\text { Black Mountain Caldera to the Bonnie Claire area (Faunt, 1994; Carr, 1984). This zone was delineated } \\
\text { to evaluate the conceptual model of more transmissive crystalline rocks associated with this feature. }\end{array}$ \\
\hline K1118PCGM8 & $\begin{array}{l}\text { This zone includes pCgm rocks in the Grapevine Mountains. The geology of this region is extremely } \\
\text { complex and the geometry and extent of these units are highly interpretive. This zone was delineated } \\
\text { so the relative uncertainty of the hydrogeologic framework model in this area could be evaluated. }\end{array}$ \\
\hline
\end{tabular}

Table 17. Description of Tertiary-Jurassic intrusives (TJi) horizontal hydraulic-conductivity parameters

\begin{tabular}{cc}
\hline \multicolumn{1}{c}{ Parameter name } & Description \\
\hline $\begin{array}{c}\text { K1121TJIU1 and } \\
\text { K1122TJIL1 }\end{array}$ & $\begin{array}{c}\text { This zone includes all Tertiary- through Jurassic-aged granitic intrusive rocks present in most of the } \\
\text { model domain exclusive of the Greenwater Range. }\end{array}$ \\
$\begin{array}{c}\text { K1121TJIU2 and } \\
\text { K1122TJIL2 }\end{array}$ & $\begin{array}{c}\text { This zone includes Tertiary- through Jurassic-aged granitic intrusive rocks present in the Greenwater } \\
\text { Range. These rocks were differentiated from granitic rocks in other parts of the model domain } \\
\text { because the presence of small-K granitic rocks resulted in too much ground-water discharge at } \\
\text { Franklin Lake playa. }\end{array}$ \\
\hline
\end{tabular}




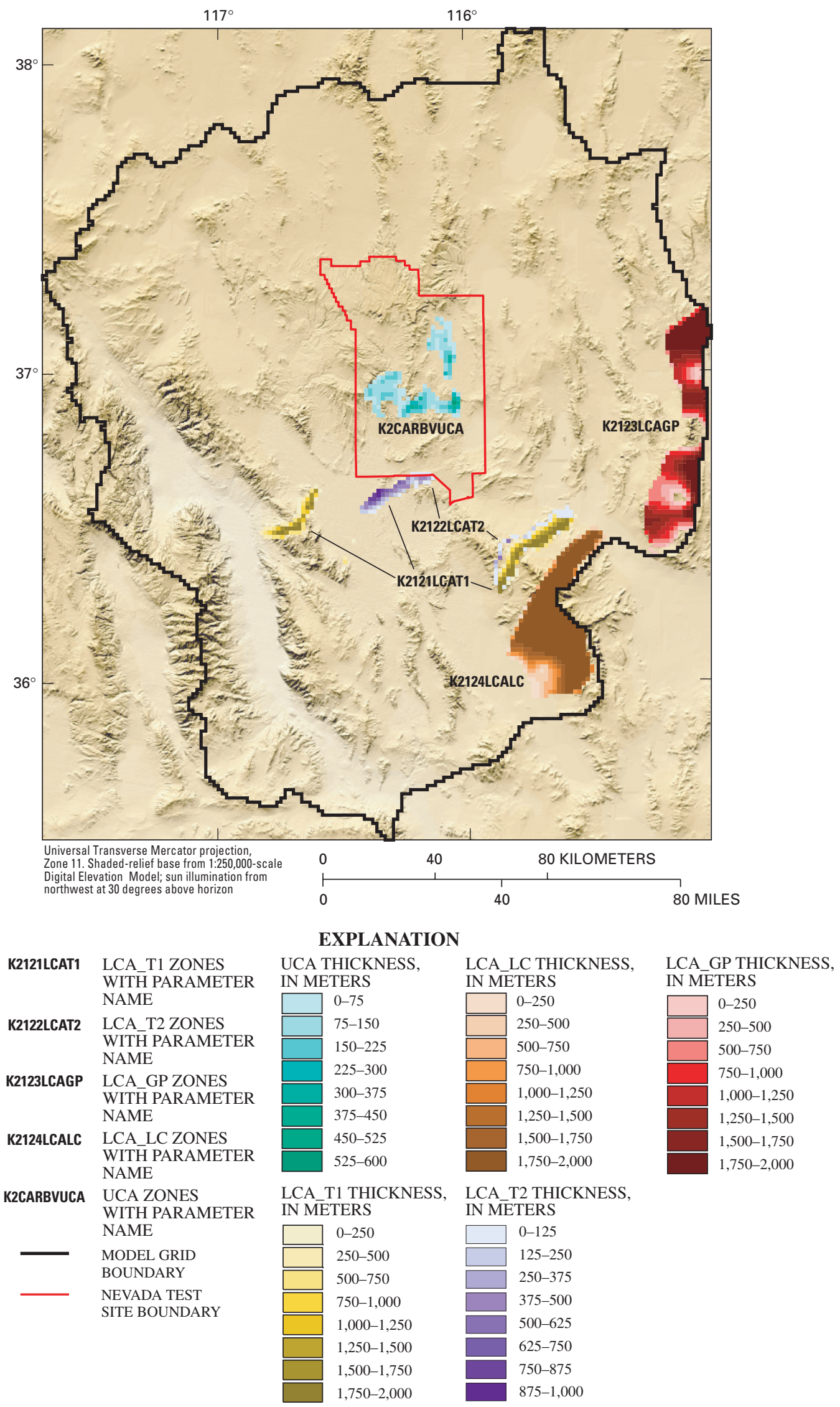

Figure 26. Definition of hydraulic-conductivity parameters and unit thickness for upper carbonate aquifer (UCA) and for lower carbonate aquifer (LCA) thrust-fault units. 


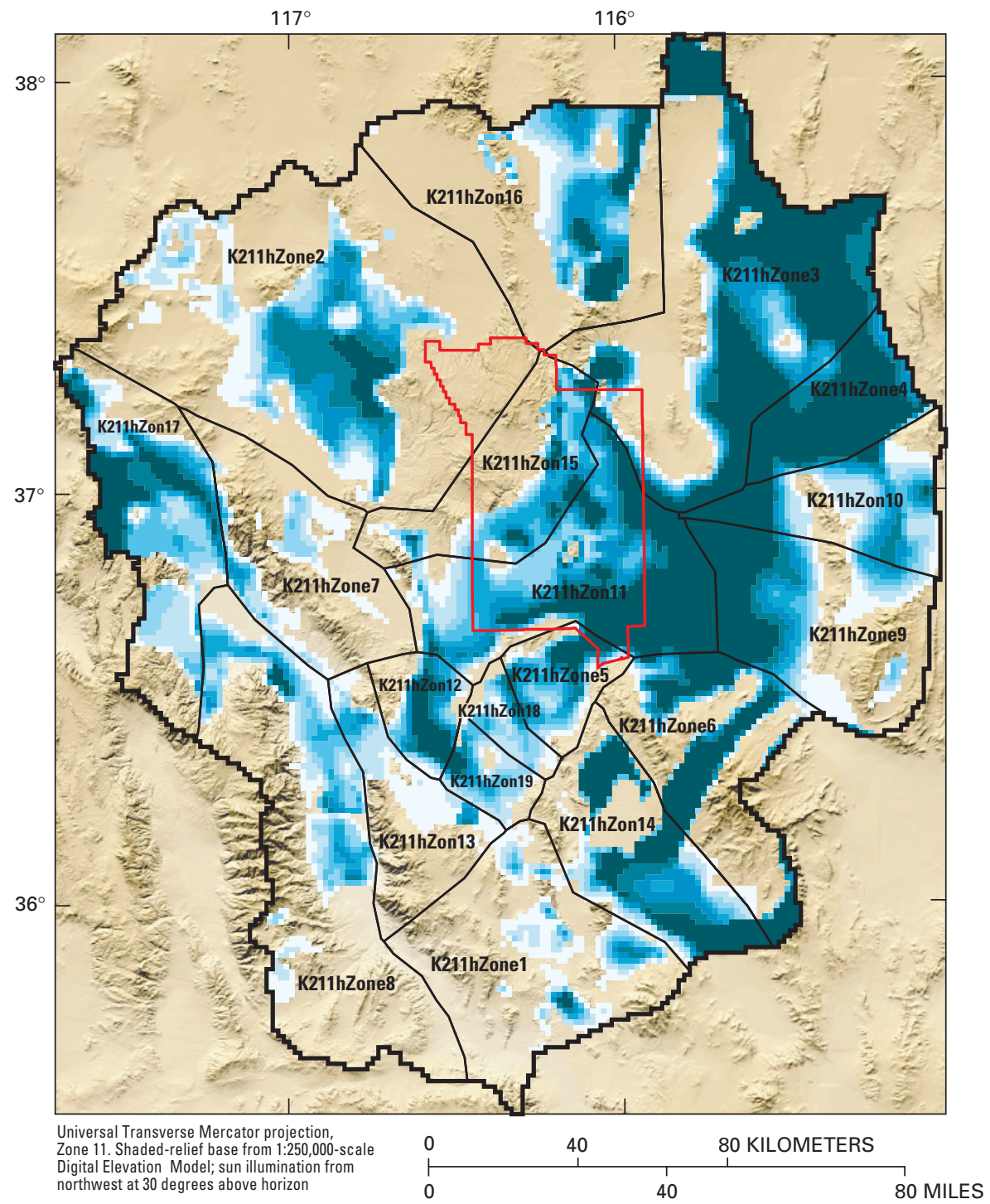

EXPLANATION

\begin{tabular}{|c|c|c|}
\hline \multirow[t]{9}{*}{ K211hZone8 } & \multirow{2}{*}{$\begin{array}{l}\text { LCA ZONES } \\
\text { WITH PARAMETER } \\
\text { NAME }\end{array}$} & LCA THICKNESS, IN METERS \\
\hline & & $0-250$ \\
\hline & \multirow{3}{*}{$\begin{array}{l}\text { MODEL GRID } \\
\text { BOUNDARY }\end{array}$} & $250-500$ \\
\hline & & $500-750$ \\
\hline & & $750-1,000$ \\
\hline & \multirow{4}{*}{$\begin{array}{l}\text { NEVADA } \\
\text { TEST SITE } \\
\text { BOUNDARY }\end{array}$} & $1,000-1,250$ \\
\hline & & $1,250-1,500$ \\
\hline & & $1,500-1,750$ \\
\hline & & $1,750-2,000$ \\
\hline
\end{tabular}

Figure 27. Definition of lower carbonate aquifer (LCA) hydraulic-conductivity zone parameters and unit thickness. 
unit still had a high CSS value, it was subdivided into spatial zones defining different K parameters (fig. 27). These zones were initially defined based on structuralphysiographic subsections identified by Carr (1990) and Faunt (1994). Although delineating these zones helped improve model fit and the simulation of regional potentiometric features, they were too coarsely, or too regionally, defined to help improve subregional features. Therefore, an iterative approach was used to refine and subdivide the structural-physiographic subsections, so that they better reflected the hydrogeologic conditions being simulated. The HFM provided the basis for modifications of the original structural-physiographic subsections. Zones were defined and adjusted to be consistent with the HFM and observed water levels. Small hydraulic gradient areas with relatively uniform geology and consistent water levels were interpreted to have related hydrogeologic characteristics. Attempts were made to keep these types of areas in one $\mathrm{K}$ parameter.

On a subregional scale, simulating the large hydraulic gradient from Pahute Mesa into Yucca Flat required additional modification of the structuralphysiographic subsection zones. For example, the boundary of the original structural zone divided the head observations representing the small hydraulic gradient areas of Yucca Flat into two zones. The northwestern boundary of the Spotted Range-Mine Mountain structural zone (parameter K211hzon11) was modified to coincide with the CP thrust west of Yucca Flat (fig. 27). This minor modification allowed heads to be better simulated in the western Yucca Flat and Yucca Mountain areas. A zone was also created in the area north of Yucca Mountain and west of Yucca Flat (parameter K211hzon15) to determine if the LCA was important in defining the large hydraulic gradient in this area (fig. 27). The LCA in this zone is juxtaposed against the Timber Mountain and Pahute Mesa volcanic units. Ultimately, an HFB was delineated in the model domain along the trend of the UCCU to provide a more effective barrier between Pahute Mesa and western Yucca Flat. This HFB (HFB_Eleana) effectively represents the more local-scale barrier effects of the UCCU that are minimized when the HFM is resampled to the flow-model grid (fig. 9).

In some cases, additional hydrogeologic detail was required to better simulate flow out of regional discharges areas. The hydrogeologic representation of the area from Ash Meadows to Franklin Lake Playa, for example, is a good illustration. Initially, one high- sensitivity LCA K parameter (parameter K211hzone5) was defined for this area (fig. 27). During a series of parameter sensitivity evaluations, this parameter was subdivided, ultimately, into three parameters (K211hzone5, K211hzon18, and K211hzon19), and it was discovered that the LCA rocks in the central part of Ash Meadows (parameter K211hzon18) had the highest sensitivity and had the most influence on hydraulic heads and flows in this area (fig. 27).

The Las Vegas Valley shear zone (LVVSZ) is another area where increasingly complex hydrogeologic conceptual models were used to improve model fit. LCA rocks in areas immediately north and east of the LVVSZ possess a distinct oroflexural bending associated with stresses at the fault zone. The hydraulic nature of LCA rocks in this area is believed to be affected by this structural condition. In fact, these areas were interpreted to have preferential flow directions along this structural fabric. To resolve high sensitivities for LCA K parameters in this area, additional LCA zone parameters (K211hzone9 and K211hzon10) were added near the shear zone (fig. 27). Although better model fit in this area resulted, the model currently does not accurately simulate observed conditions in this area. This may result from an inaccurate representation of the hydrogeologic complexity of the area in the current HFM. A summary of how lower carbonate aquifer parameters were subdivided is presented in table 14. A description of LCA parameters is presented in table 18 .

\section{Volcanic Rocks}

The volcanic rock group consists of the undifferentiated volcanic (VU), volcanic aquifer (VA), volcanic confining unit (VCU), and the Timber Mountain/Pahute Mesa hydrogeologic units (TBA, TBCU, TBQ, TCB, TC, and TMA). Although these units occur throughout the modeled area, they most commonly occur in the central and northern parts of the domain in the vicinity of the NTS where they have been extensively studied (fig. 28 through fig. 36).

Initially, all of the volcanic units were grouped into one $\mathrm{K}$ parameter that was calculated as being the second most sensitive $\mathrm{K}$ parameter. The first step in evaluating these units was to subdivide them into three parameters consisting of Timber Mountain/Pahute Mesa volcanic units, Yucca Mountain volcanic units, and undifferentiated volcanic rocks (VU). Although the spatial extent of the Timber Mountain/Pahute 
Table 18. Description of lower carbonate aquifer (LCA) horizontal hydraulic-conductivity parameters

\begin{tabular}{|c|c|}
\hline Parameter name & Description \\
\hline K211hzone1 & $\begin{array}{l}\text { This zone includes LCA rocks in the SE Walker Lane structural zone southwest of the Pahrump-State Line } \\
\text { Fault in the area around Shoshone and Tecopa, Calif. LCA rocks in this zone occur in fairly discontin- } \\
\text { uous, but relatively thick sections. }\end{array}$ \\
\hline K211hzone2 & $\begin{array}{l}\text { This zone includes LCA rocks in the northwest part of the model domain in the Walker Lane structural } \\
\text { zone. LCA in this zone is concentrated in an area extending north of Oasis Valley and northern Sarco- } \\
\text { batus Flat to Stonewall Mountain and northeast to Gold Flat and extreme western Pahute Mesa. Because } \\
\text { these LCA rocks occur only in the subsurface, the geometry, extent, and hydraulic nature are highly } \\
\text { interpretive. }\end{array}$ \\
\hline K211hzone3 & $\begin{array}{l}\text { This zone includes a thick section of LCA rocks in the Basin and Range structural-physiographic subsec- } \\
\text { tion of the study area. The LCA rocks in this area are slightly extended and interpreted as being fairly } \\
\text { transmissive. }\end{array}$ \\
\hline K211hzone4 & $\begin{array}{l}\text { This zone includes LCA rocks that are interpreted as having similar attributes as those in K } 211 \text { hzone } 3 \text {. } \\
\text { However, these LCA rocks have potentially larger hydraulic conductivities associated with the north- } \\
\text { east-southwest trending faulting in the Pahranagat shear zone. }\end{array}$ \\
\hline K211hzone5 & $\begin{array}{l}\text { This zone includes LCA rocks around and beneath Amargosa Flats and was delineated because of } \\
\text { extremely high parameter sensitivities for LCA rocks in the Ash Meadows area. }\end{array}$ \\
\hline K211hzone6 & $\begin{array}{l}\text { This zone includes LCA rocks in the Spring Mountains. It was delineated to resolve issues of high param- } \\
\text { eter sensitivity and large hydraulic gradients observed on the northeast side of the Spring Mountains. }\end{array}$ \\
\hline K211hzone7 & $\begin{array}{l}\text { This zone includes LCA rocks in the Grapevine Mountains in the vicinity of Bullfrog Hills. This zone was } \\
\text { delineated to test the hypothesis of smaller hydraulic conductivity associated with hydrothermal alter- } \\
\text { ation in LCA rocks near Oasis Valley. }\end{array}$ \\
\hline K211hzone8 & $\begin{array}{l}\text { This zone includes LCA rocks in the Inyo-Mono structural-physiographic subsection of the study area. } \\
\text { This zone delineates LCA rocks that occur mostly in the Panamint Range and in the subsurface beneath } \\
\text { Death Valley. Very little is known about the hydraulic nature of these rocks. }\end{array}$ \\
\hline K211hzone9 & $\begin{array}{l}\text { This zone includes LCA rocks in an area of distinct oroflexural bending immediately north of the Las } \\
\text { Vegas Valley fault. The hydraulic nature of LCA rocks in this area is believed to be affected by this } \\
\text { structural condition. }\end{array}$ \\
\hline K211hzon10 & $\begin{array}{l}\text { This zone includes LCA rocks immediately north of the Las Vegas flexural zone described in } \\
\text { K } 211 \text { hzone } 9 \text {. This zone was originally delineated because of its somewhat different structural character } \\
\text { from K211hzone9. }\end{array}$ \\
\hline K211hzon11 & $\begin{array}{l}\text { This zone includes very thick, highly fractured and faulted LCA rocks mostly in the Spotted Range- } \\
\text { Mine Mountain structural zone. The hydraulic nature of LCA rocks in this area is believed to be affected } \\
\text { by the extreme northeast-southwest faulting and fracturing. }\end{array}$ \\
\hline K211hzon12 & $\begin{array}{l}\text { This zone includes LCA rocks at the southern end of the Funeral Mountains. The geometry and extent of } \\
\text { LCA rocks in this zone are highly interpretive in the subsurface. }\end{array}$ \\
\hline K211hzon13 & $\begin{array}{l}\text { This zone includes LCA rocks west and northwest of Death Valley Junction along Furnace Creek Wash. } \\
\text { This zone was delineated to evaluate the sensitivity of LCA rocks that could provide a ground-water } \\
\text { pathway from the Amargosa Valley to the Furnace Creek discharge. }\end{array}$ \\
\hline K211hzon14 & $\begin{array}{l}\text { This zone includes a thick section of LCA rocks interpreted as extending beneath Pahrump Valley. Rocks } \\
\text { in this zone are believed to be affected by extensional faulting that caused the development of Pahrump } \\
\text { Valley. }\end{array}$ \\
\hline K211hzon15 & $\begin{array}{l}\text { This zone includes a relatively thick section of LCA north and west of the CP thrust. Rocks in this zone } \\
\text { were delineated to account for the uncertainty in the geometry and extent of the LCA and the potential } \\
\text { interfingering with rocks having similar hydraulic characteristics of the UCCU. }\end{array}$ \\
\hline K211hzon16 & $\begin{array}{l}\text { This zone includes a relatively thick, isolated section of LCA rocks interpreted as occurring beneath } \\
\text { Kawich Valley and northern Cactus Flats. }\end{array}$ \\
\hline K211hzon17 & $\begin{array}{l}\text { This zone includes LCA rocks in the Cottonwood Mountains and Last Chance Range. The geometry, } \\
\text { extent, and hydraulic nature of these rocks in the subsurface are highly uncertain. }\end{array}$ \\
\hline K211hzon18 & $\begin{array}{l}\text { This zone includes LCA rocks in the immediate vicinity of the Ash Meadows spring line. This zone was } \\
\text { delineated to account for the highly fractured nature of LCA rocks that control a large component of } \\
\text { ground-water discharge in the model. }\end{array}$ \\
\hline K211hzon19 & $\begin{array}{l}\text { This zone includes LCA rocks in the Franklin Lake playa area. This zone was delineated to differentiate } \\
\text { these LCA rocks from those in the immediate vicinity of Ash Meadows. }\end{array}$ \\
\hline
\end{tabular}

\footnotetext{
66 A Three-Dimensional Numerical Model of Predevelopment Conditions in the Death Valley Regional Ground-Water Flow System,
} Nevada and California 
Mesa and Yucca Mountain volcanic units is relatively small, they had a high sensitivity that probably is due to the large number of observation boreholes penetrating these units. To improve model fit, K parameters were created for both of the Yucca Mountain hydrogeologic units (VA and VCU). Timber Mountain/Pahute Mesa units (TBA, TBCU, TBQ, TCB, TC, and TMA) were also subdivided into individual parameters. As a result of adding these parameters, model fit in the NTS area was improved; most of the improvement could be attributed to the TMA and VA parameters, which appeared to have the most impact on controlling hydraulic heads and improving model fit. The TC, TBCU, and TBQ Timber Mountain/Pahute Mesa hydrogeologic units were further subdivided into zone parameters to isolate those rocks located in the Claim Canyon caldera area. These zone parameters were developed to allow for a smaller $\mathrm{K}$ in the volcanic units of the Claim Canyon caldera, thus providing for a more effective barrier between Pahute Mesa and Yucca Mountain. Descriptions of the TC, TBCU, and TBQ units that were subdivided into zone parameters are provided in table 19 , table 20 , and table 21 . The spatial distribution and definition of all Timber Mountain/Pahute Mesa hydrogeologic units are presented in figs. 28 through 33.

The differentiation of the VA and VCU parameters was initially intended to isolate units of similar hydrologic characteristics. In fact, the Yucca Mountain volcanic units (VA and VCU) were intended to represent the aquifers (VA) and confining units (VCU) in the NTS area; however, in the final calibrated model configuration the VA and VCU units were further subdivided into zone parameters (figs. 34 and 35) allowing for differing $\mathrm{K}$ values in different parts of Yucca Flat and Yucca Mountain. This result illustrates the high degree of spatial variability in the hydraulic properties of these units from the Yucca Flat/Rainier Mesa area to the Yucca Mountain area. In fact, geologic formations that are aquifers in Yucca Flat commonly grade into confining units at Yucca Mountain. Laczniak and others (1996, p. 15 and table 1) describe the hydrogeologic reasoning for this variation, stating that the hydrologic properties of these volcanic deposits are governed chiefly by the mode of eruption and cooling, by the extent of fracturing, and by the degree of secondary alteration. These characteristics typically vary within a given hydrogeologic unit. The final parameter configuration of the VA and VCU units appears to support this reasoning. Descriptions of the VA and VCU parameters are provided in tables 22 and 23 .

Increasingly detailed conceptualizations of the VU unit also were required to improve model fit in various parts of the model domain. For example, water levels in the northern part of the model domain appeared to be influencing the sensitivity of the VU parameter. Therefore, a zone array was used to subdivide the VU hydrogeologic unit based on volcanic centers in the region (fig. 36). Because hydrologic data were insufficient to delineate all of these volcanic centers, several were grouped together in the southern and eastern parts of the model domain. The final calibrated model configuration included eight VU zone parameters, the most sensitive of which was K315VU_NC located in Cactus and Gold Flats (fig. 36).

The accurate simulation of the large hydraulic gradient in the Bullfrog Hills area required increasingly complex representations of the hydrogeologic conceptual model in the vicinity of Oasis Valley. These conceptual models were required to improve model fit for both hydraulic heads and groundwater discharges. Originally, discharge at Oasis Valley was smaller than expected, and water levels immediately south of the Bullfrog Hills were too low. To improve model fit, an additional zone parameter (K318VU_BFH) for the VU hydrogeologic unit was created for the Bullfrog Hills region (fig. 36). In addition, an HFB was delineated along the trend of the Bullfrog Hills to represent a geometrically complex detachment fault that is interpreted to impede groundwater flow from Sarcobatus Flat to the northwestern Amargosa Valley (fig. 9). Although this conceptual alternative improved model fit to both hydraulic heads and ground-water discharges, the final calibrated model configuration still does not accurately simulate observed conditions. Perhaps an improved representation of the complex 3D hydrogeology in the vicinity of the Bullfrog Hills is required to better simulate ground-water conditions in this part of the model domain.

The final calibrated model configuration contains numerous parameters representing the hydrogeologic units in the volcanic rocks of the Death Valley region. Although many of the parameters do not have high sensitivities, their definition was warranted to evaluate the importance of various hydrogeologic units in the flow model. A summary of how volcanic 


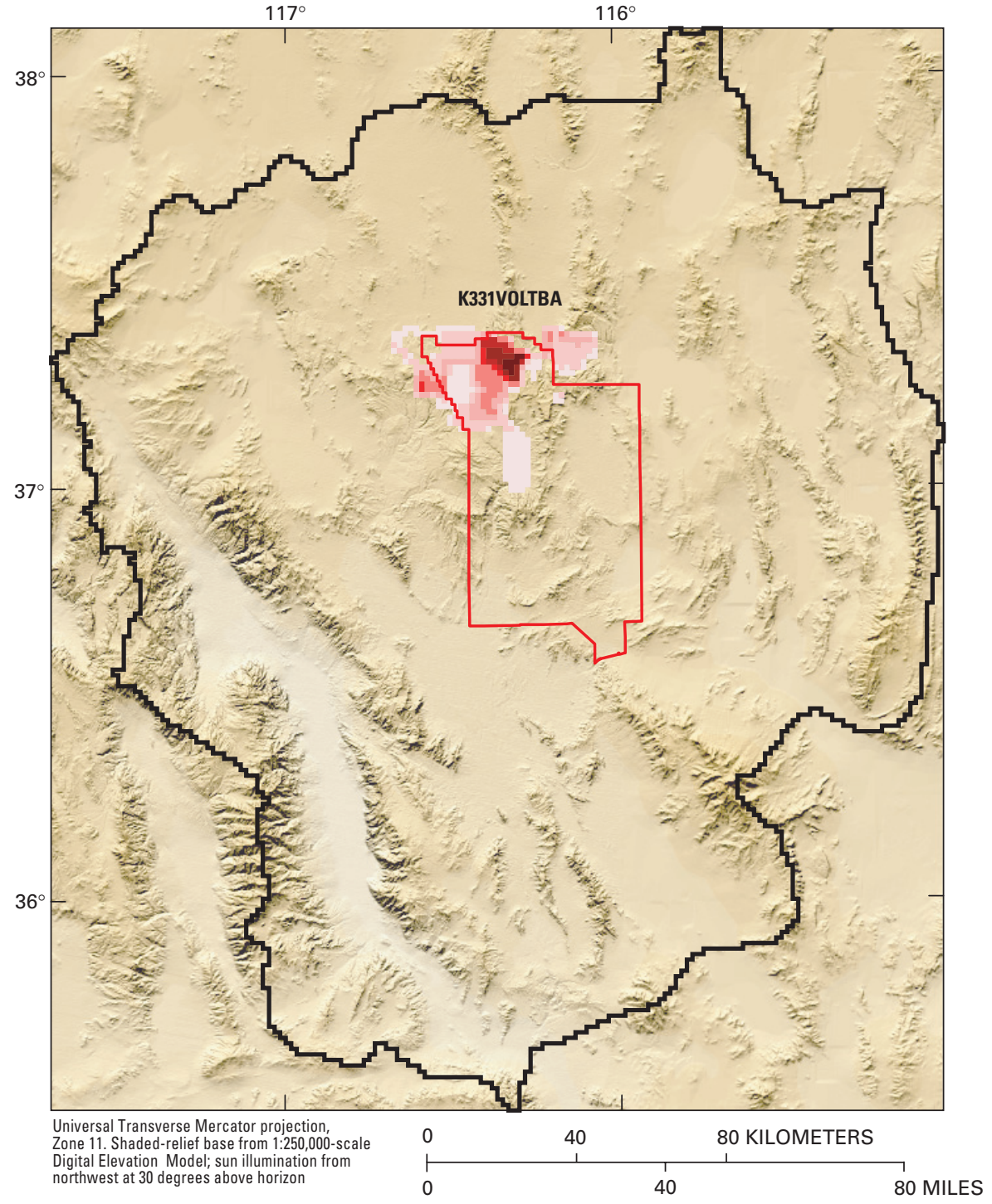

EXPLANATION

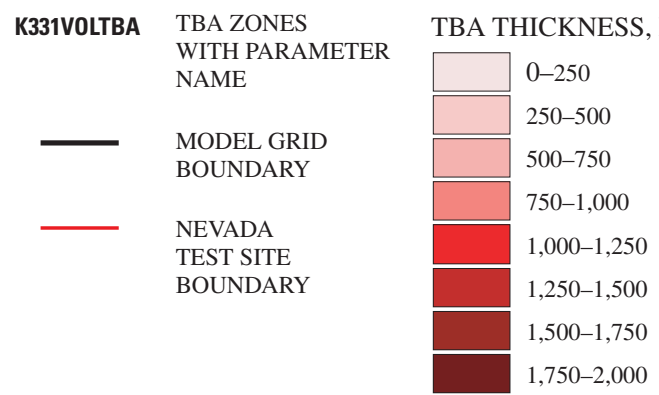

Figure 28. Definition of Belted Range aquifer (TBA) hydraulic-conductivity zone parameters and unit thickness. 


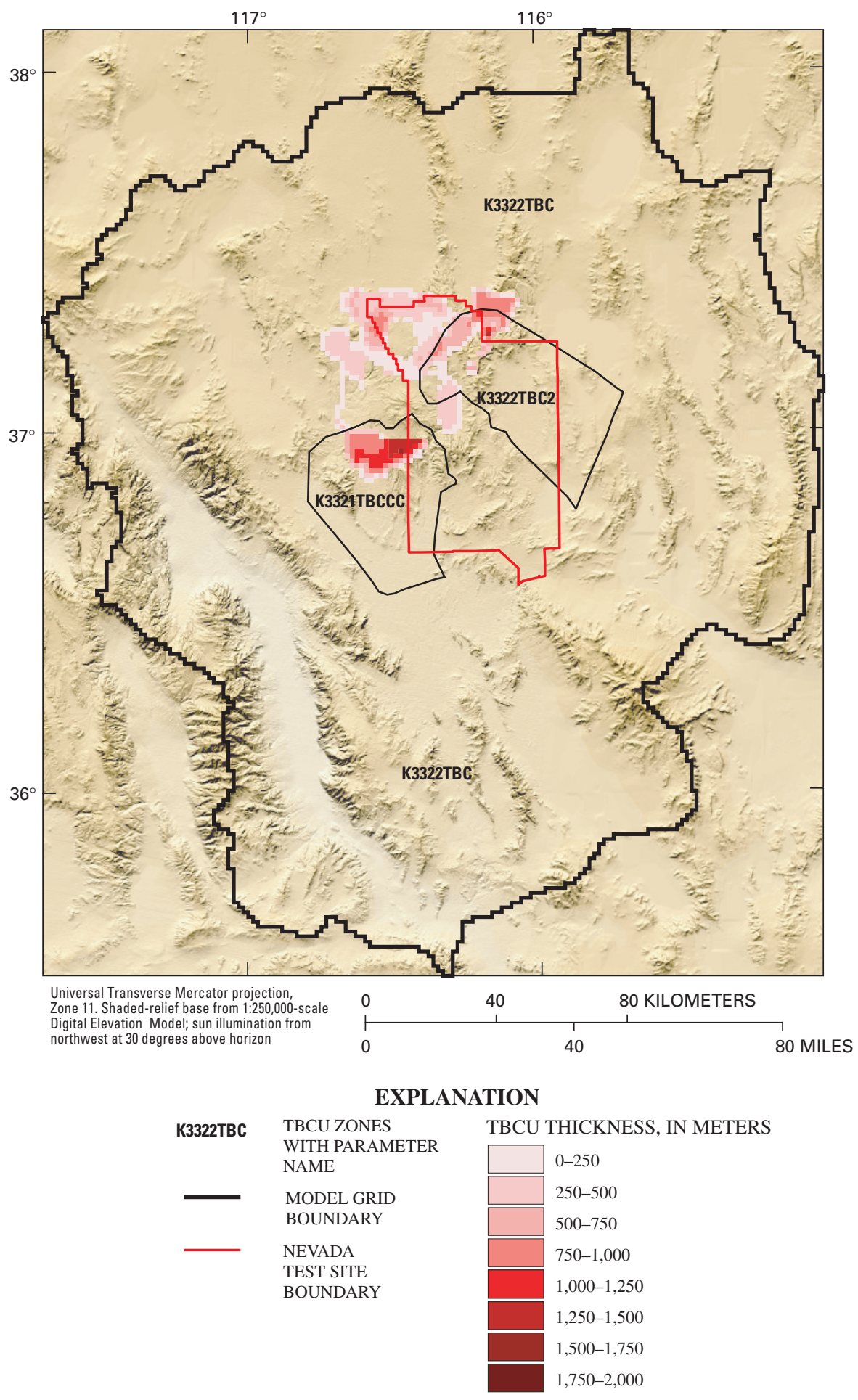

Figure 29. Definition of Timber Mountain/Pahute Mesa basal confining unit (TBCU) hydraulic-conductivity zone parameters and unit thickness. 


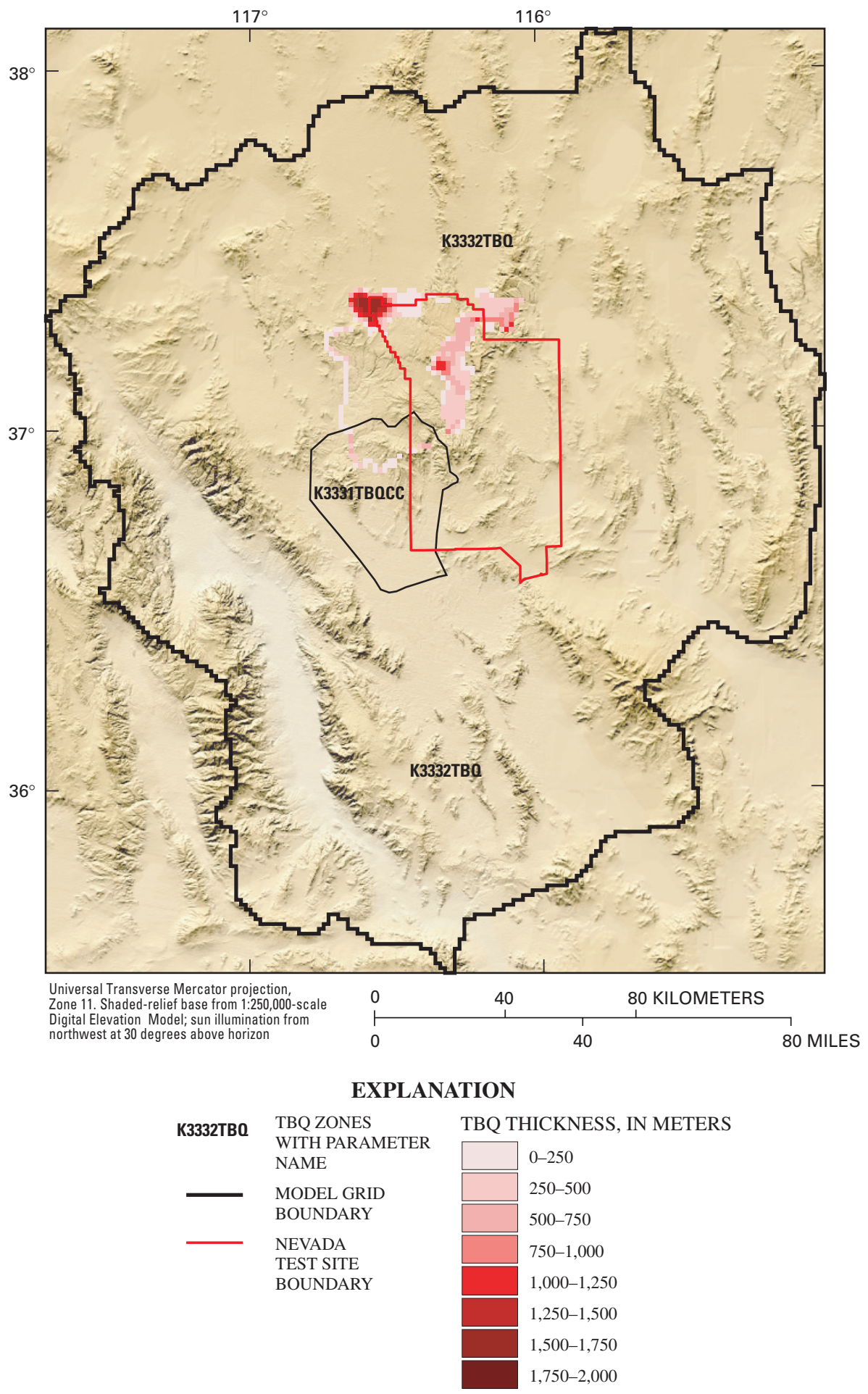

Figure 30. Definition of Timber Mountain/Pahute Mesa basal aquifer (TBQ) hydraulic-conductivity zone parameters and unit thickness. 


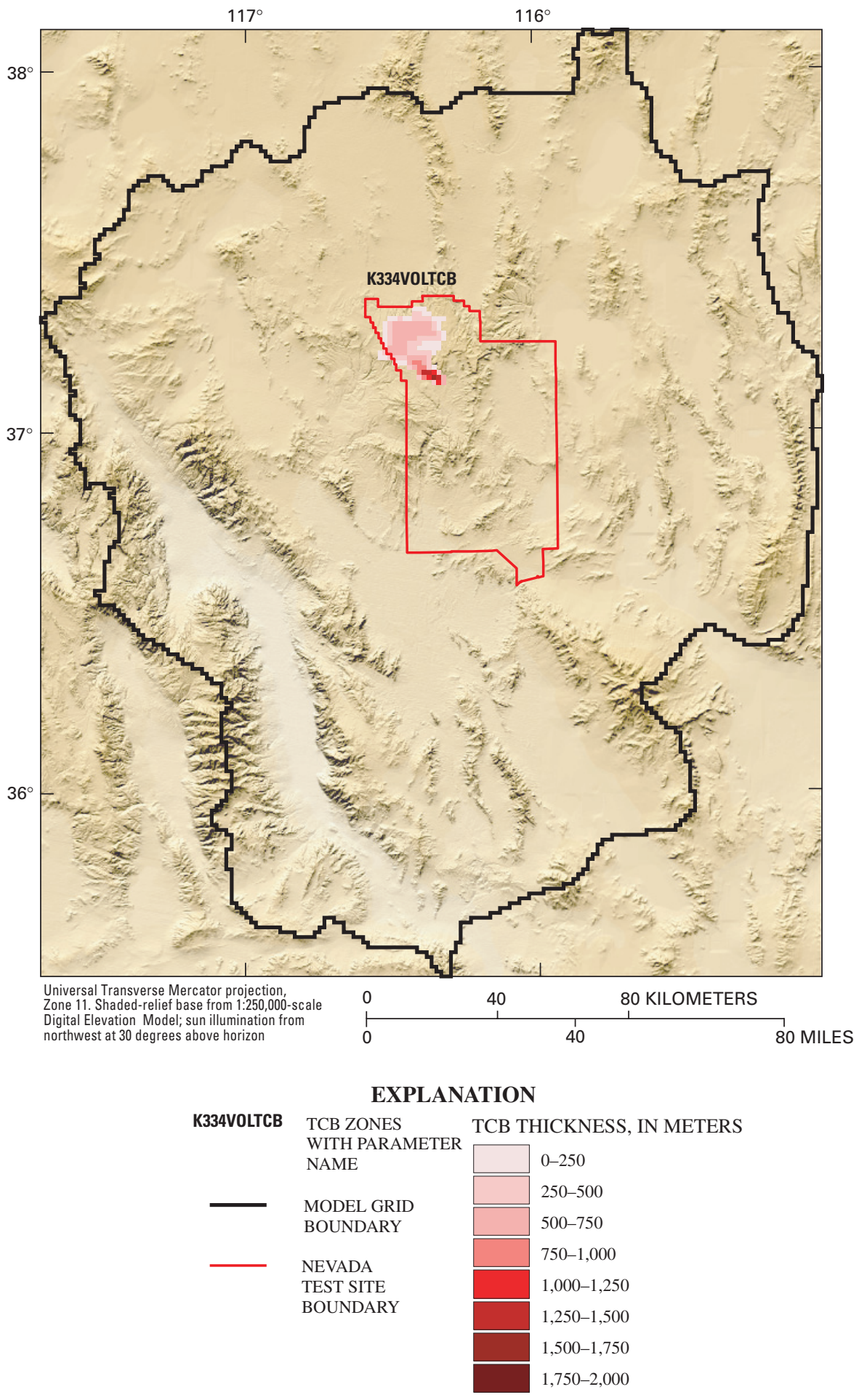

Figure 31. Definition of Bullfrog confining unit (TCB) hydraulic-conductivity zone parameters and unit thickness. 


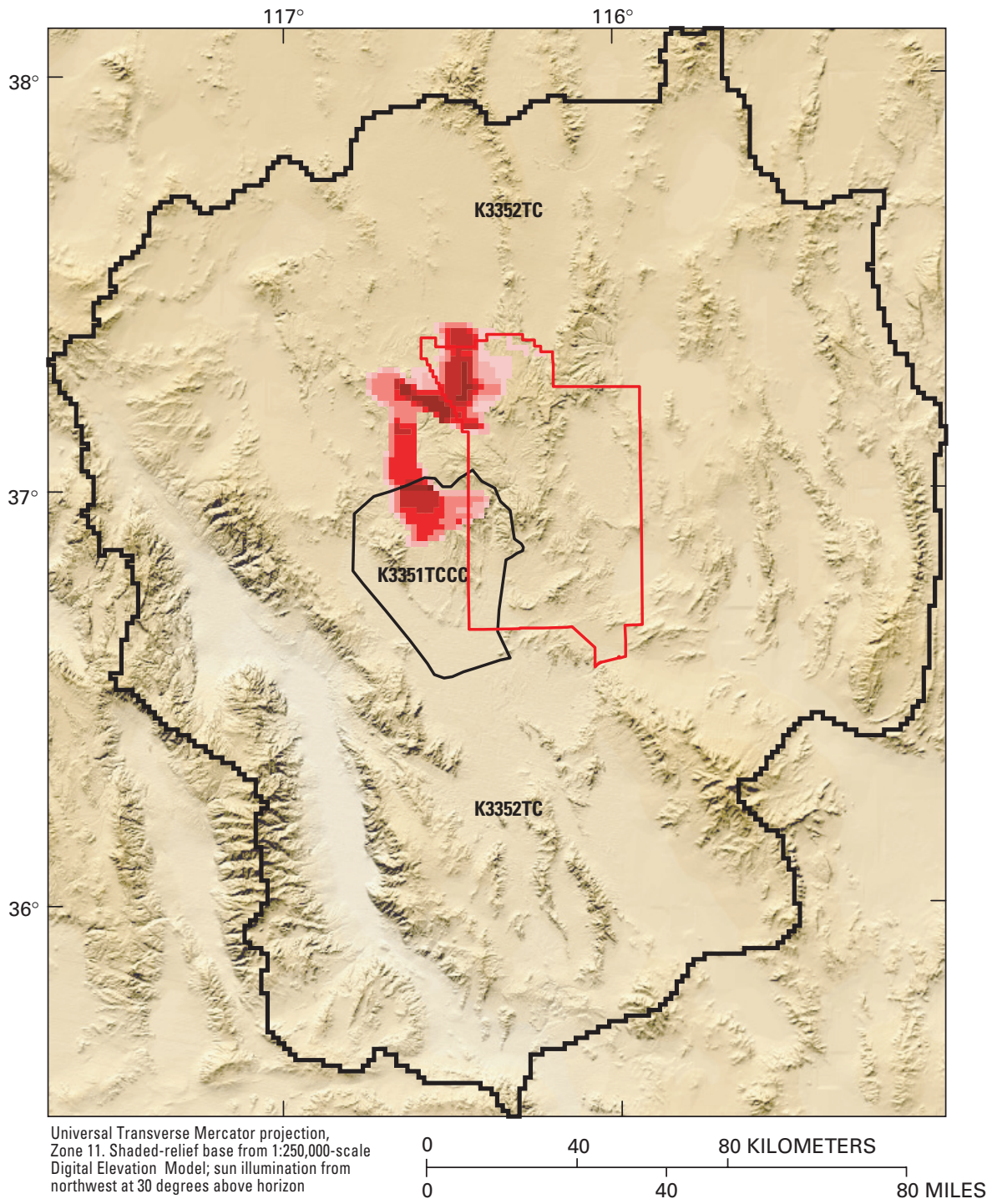

\section{EXPLANATION}

K3352TC TC ZONES $\quad$ TC THICKNESS, IN METERS WITH PARAMETER
NAME

\begin{tabular}{l|l} 
& \\
MODEL GRID & $250-500$
\end{tabular} BOUNDARY $\quad \square 00-750$

NEVADA TEST SITE BOUNDARY $750-1,000$ $1,000-1,250$ $1,250-1,500$ $1,500-1,750$ $1,750-2,000$

Figure 32. Definition of Paintbrush/Calico Hills tuff cone (TC) hydraulic-conductivity zone parameters and unit thickness. 


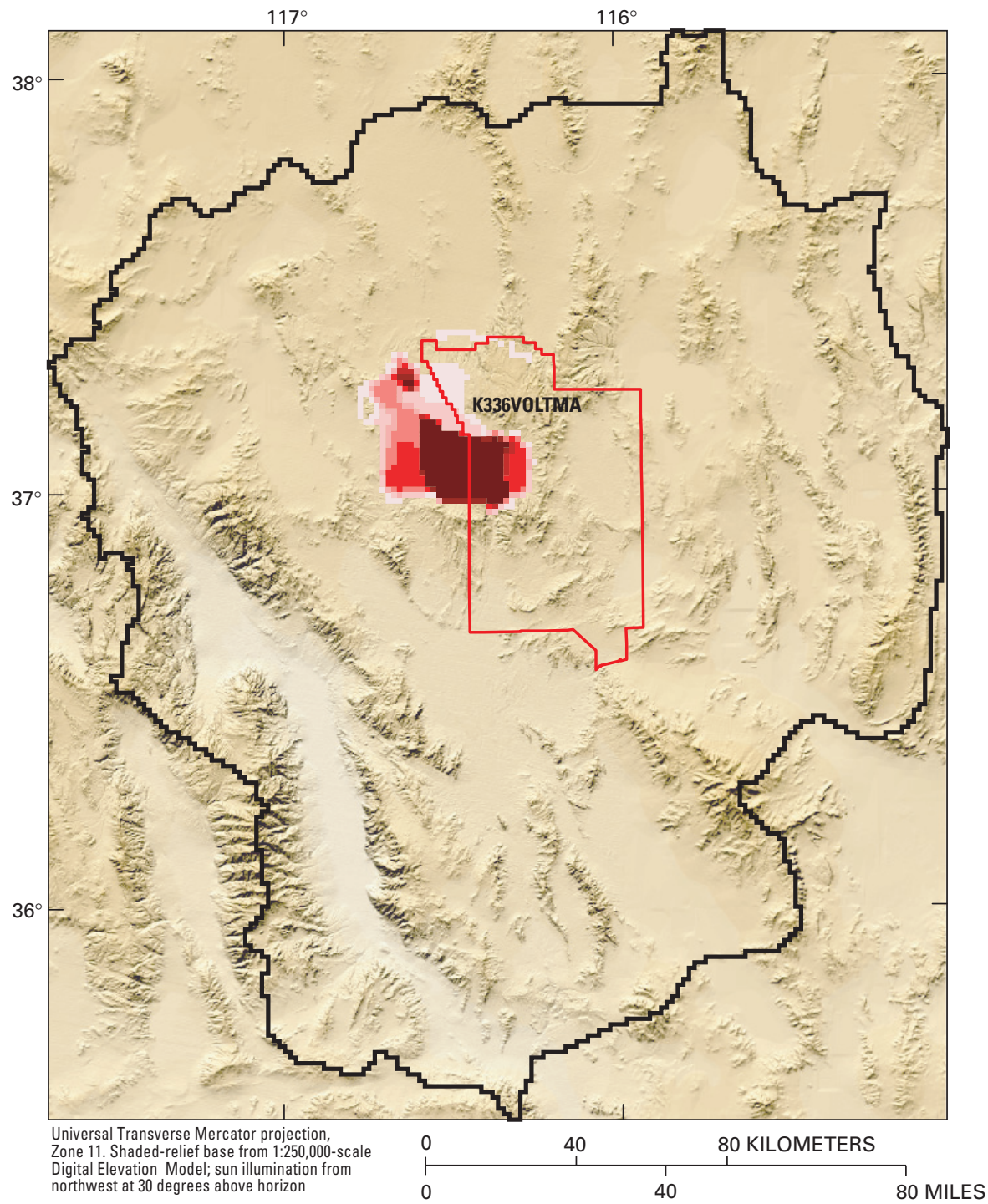

EXPLANATION

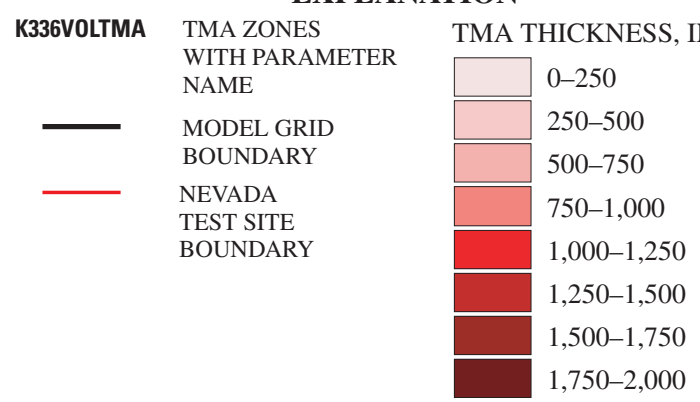

Figure 33. Definition of Timber Mountain aquifer (TMA) hydraulic-conductivity zone parameters and unit thickness. 


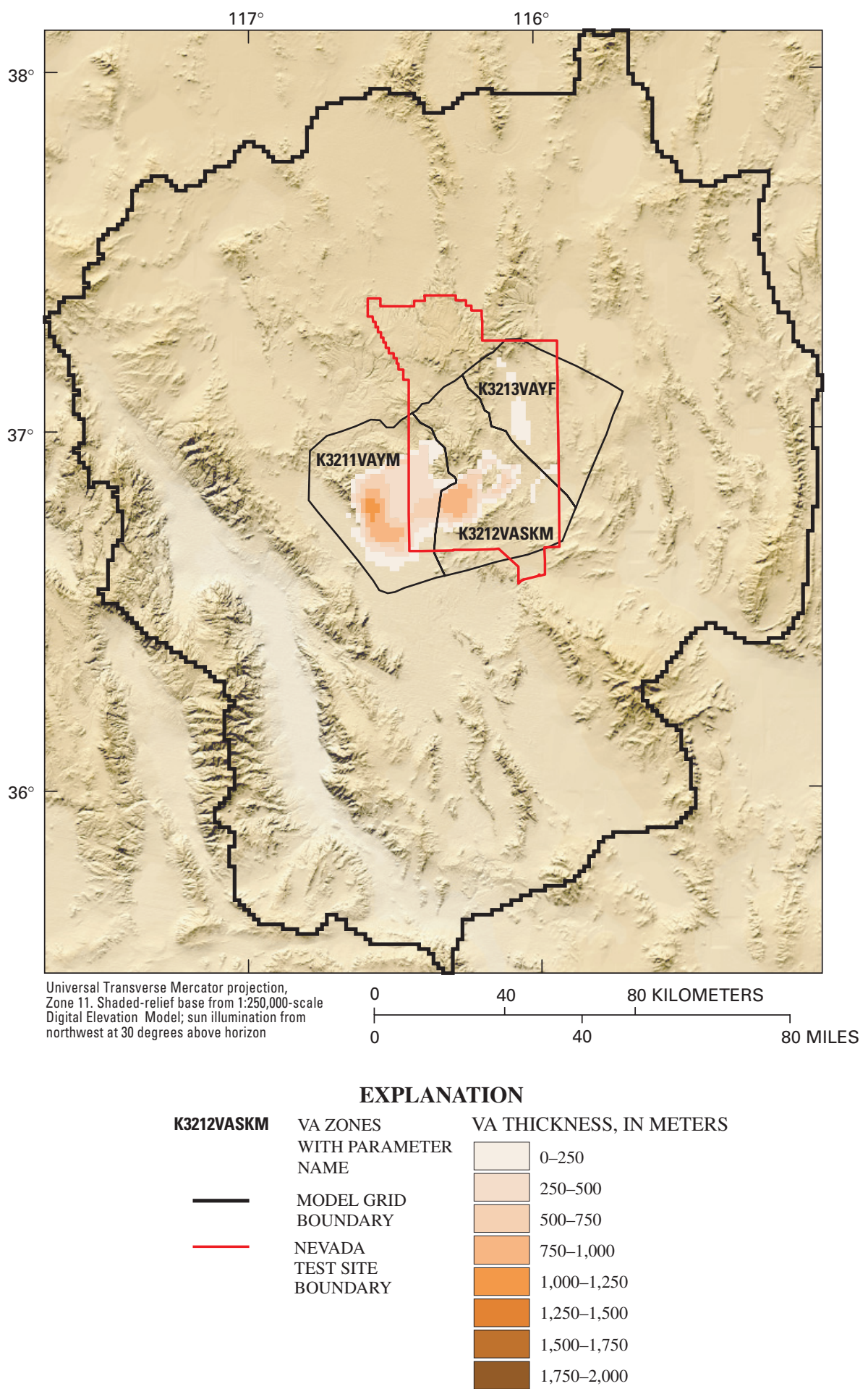

Figure 34. Definition of volcanic aquifer (VA) hydraulic-conductivity zone parameters and unit thickness. 


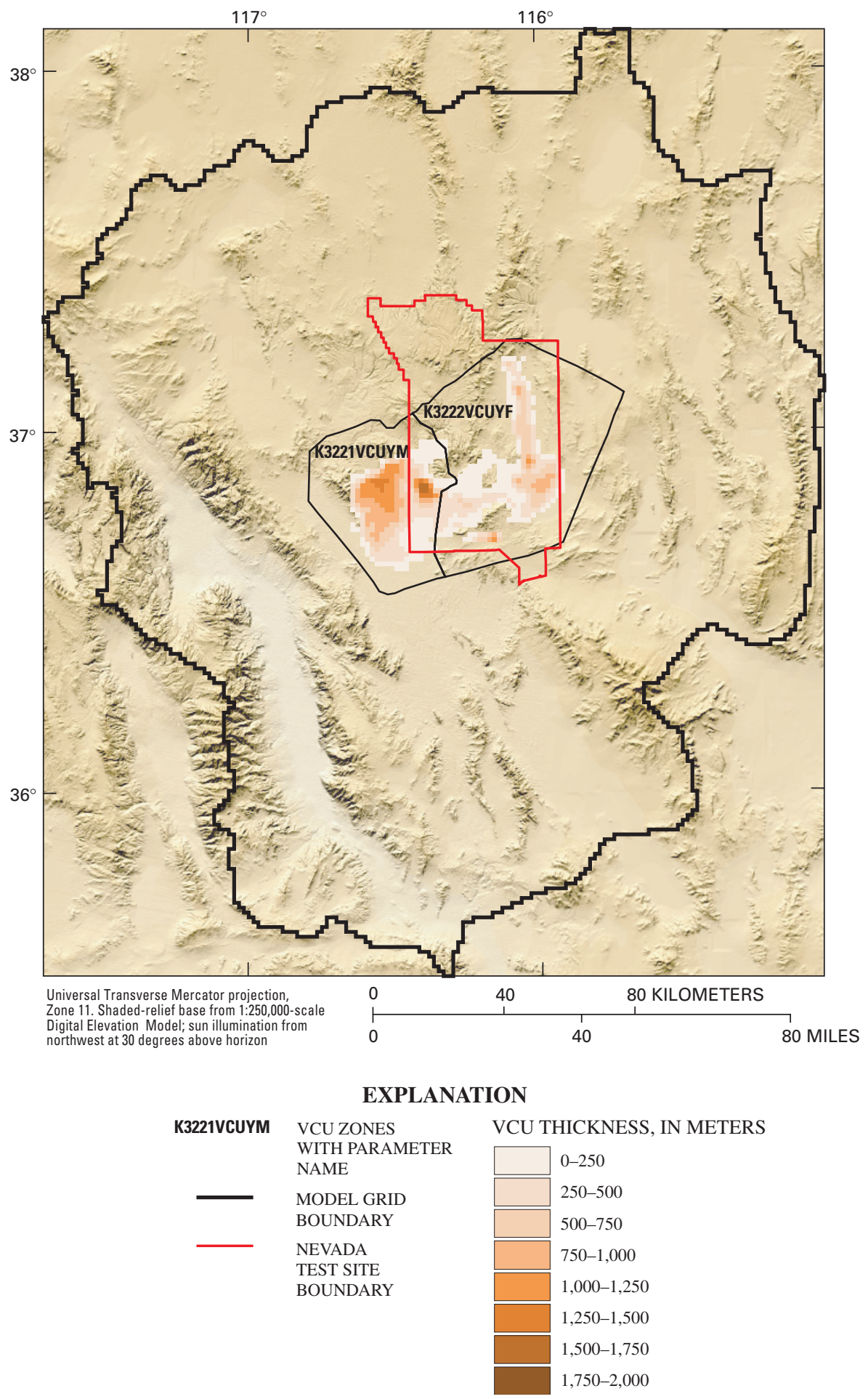

Figure 35. Definition of volcanic confining unit (VCU) hydraulic-conductivity zone parameters and unit thickness. 


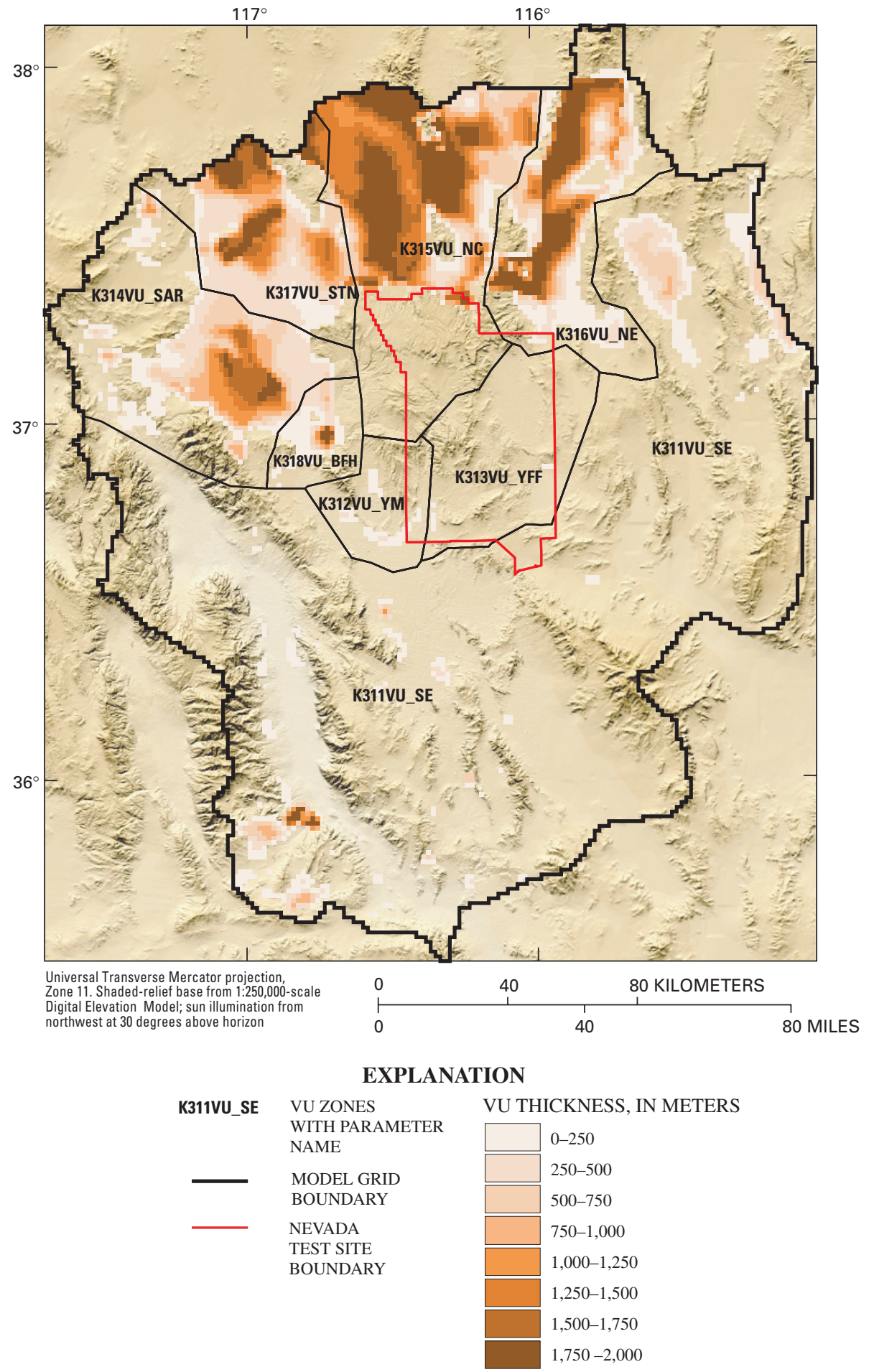

Figure 36. Definition of undifferentiated volcanic rocks (VU) hydraulic-conductivity zone parameters and unit thickness. 
Table 19. Description of Paintbrush/Calico Hills tuff cone (TC) horizontal hydraulic-conductivity parameters

\begin{tabular}{lc}
\hline \multicolumn{1}{c}{ Parameter name } & Description \\
\hline K3351TCCC & $\begin{array}{c}\text { This zone includes the TC rocks in the Claim Canyon caldera area. This zone was delineated to differen- } \\
\text { tiate these TC rocks that are interpreted as having smaller K resulting from hydrothermal alteration. } \\
\text { K3352TC }\end{array}$ \\
This zone includes the TC rocks in the Timber Mountain area.
\end{tabular}

Table 20. Description of Timber Mountain/Pahute Mesa basal confining unit (TBCU) horizontal hydraulic-conductivity parameters

\begin{tabular}{ll}
\hline \multicolumn{1}{c}{ Parameter name } & \multicolumn{1}{c}{ Description } \\
\hline K3321TBCCC & $\begin{array}{l}\text { This zone includes the TBCU rocks in the Claim Canyon caldera area. This zone was delineated to differ- } \\
\text { entiate these TBCU rocks that are interpreted as having smaller K resulting from hydrothermal alter- } \\
\text { ation. } \\
\text { This zone includes the TBCU rocks in the Timber Mountain area. } \\
\text { T3322TBC }\end{array}$ \\
T3322TBC2 & $\begin{array}{l}\text { This zone includes the TBCU rocks in the eastern Pahute Mesa area. This zone was delineated to differen- } \\
\text { tiate these TBCU rocks that are interpreted as having larger K than other rocks in the Timber Mountain } \\
\text { caldera. }\end{array}$ \\
\hline
\end{tabular}

Table 21. Description of Timber Mountain/Pahute Mesa basal aquifer (TBQ) horizontal hydraulic-conductivity parameters

\begin{tabular}{ll}
\hline \multicolumn{1}{c}{ Parameter name } & Description \\
\hline K3331TBQCC & $\begin{array}{l}\text { This zone includes the TBQ rocks in the Claim Canyon caldera area. This zone was delineated to differen- } \\
\text { tiate these TBQ rocks that are interpreted as having smaller K resulting from hydrothermal alteration. } \\
\text { K3332TBQ }\end{array}$ \\
This zone includes the TBQ rocks in the Timber Mountain area.
\end{tabular}

Table 22. Description of volcanic aquifer (VA) horizontal hydraulic-conductivity parameters

\begin{tabular}{ll}
\hline Parameter name & Description \\
\hline K3211VAYM & $\begin{array}{c}\text { This zone includes the VA rocks in the Yucca Mountain area. This zone was delineated to differentiate the } \\
\text { variable K of these VA rocks. The variability is recognizable as a result of the large concentration of } \\
\text { hydraulic-head observations in this unit. } \\
\text { This zone includes the VA rocks in the eastern Jackass Flats area. This zone was delineated to differentiate } \\
\text { the variable K of these VA rocks. The variability is recognizable as a result of the large concentration of } \\
\text { hydraulic-head observations in this unit. } \\
\text { This zone includes the VA rocks in the Yucca Flat area. This zone was delineated to differentiate the vari- } \\
\text { able K of these VA rocks. The variability is recognizable as a result of the large concentration of } \\
\text { hydraulic-head observations in this unit. }\end{array}$ \\
\hline
\end{tabular}

Table 23. Description of volcanic confining unit (VCU) horizontal hydraulic-conductivity parameters

\begin{tabular}{lc}
\hline Parameter name & Description \\
\hline K3221VCUYM & $\begin{array}{c}\text { This zone includes the VCU rocks in the Yucca Mountain area. This zone was delineated to differentiate } \\
\text { these VCU rocks as having hydraulic properties more representative of ash-flow tuffs in the Yucca } \\
\text { Mountain area. } \\
\text { This zone includes the VCU rocks in the Yucca Flat and eastern Jackass Flats area. This zone was delin- } \\
\text { eated to differentiate these VCU rocks as having hydraulic properties more representative of welded } \\
\text { tuffs in the Yucca Flat and eastern Jackass Flats area. }\end{array}$ \\
\hline
\end{tabular}


parameters were subdivided is presented in table 14. A description of VU parameters is presented in table 24 .

\section{Basin-Fill Units}

The basin-fill rock group consists of the Quaternary-Tertiary valley-fill alluvium (QTal), QuaternaryTertiary playa deposits (QTp), and Tertiary sediments/Death Valley section (TSDVS) hydrogeologic units. Regionally, these units are relatively thin and discontinuous between basins; they dominate local ground-water flow patterns. The QTal is the most widely distributed basin-fill unit, and it is present in all basins in the region. The QTp, which has a smaller areal extent than the QTal, only occurs in playa areas, and is not present in all basins. The TSDVS is present predominantly in Death Valley but occurs locally in the central and southern parts of the model domain. Initially these units were grouped into one $\mathrm{K}$ parameter, and the sensitivity was less than the carbonate and volcanic rock parameters. Parameters were subsequently created for the individual units, and some improvement in model fit was achieved.

Because the depositional conditions vary in each valley, zone parameters were defined to evaluate the impact of this variability on the hydrologic characteristics of basin-fill units throughout the region (figs. 37,
38, and 39). For example, QTp zone parameters were created to group playas with similar depositional environments (fig. 37). Discharging playas similar to the Death Valley saltpan contain large amounts of salts whereas playas similar to Yucca Flat contain large amounts of fine-grained clays typical of a dry playa. Zone parameters also were used to determine the importance of TSDVS units in controlling groundwater discharge to various parts of Death Valley (fig. 38). In many cases, the QTp and TSDVS units were used to limit the flow of ground water to discharge areas.

Basin-fill parameters predominantly influenced water levels and flows near discharge areas. For example, the relatively thick sequence of QTal near Bennett Spring in Pahrump Valley controlled the direction of ground-water flow paths in the basin fill (fig. 39). Flow out of observations G-STEWRT-P and G-STEWRT-V in Stewart Valley and observations G-PAH-BENT and G-PAH-MANS in Pahrump Valley were influenced by the hydraulic conductivity of the QTal parameter (K415VALPAH) in this area. Similarly, a thick sequence of QTal also exists near Amargosa Farms. The hydraulic conductivity of this QTal parameter (K413VALAMV) influences hydraulic heads and ground-water discharges near Ash Meadows and Franklin Lake playa (fig. 18). A

Table 24. Description of undifferentiated volcanic rocks (VU) horizontal hydraulic-conductivity parameters

\begin{tabular}{ll}
\hline \multicolumn{1}{c}{ Parameter name } & Description \\
\hline K311VU_SE & $\begin{array}{c}\text { This zone includes undifferentiated VU rocks in the southern and eastern parts of the model domain. } \\
\text { This zone includes VU rocks in the immediate vicinity of Yucca Mountain and Crater Flat. VU rocks in } \\
\text { this zone were delineated because they exhibit dominantly north-south faulting and fracturing. } \\
\text { This zone includes VU rocks in the immediate vicinity of Yucca and Frenchmen Flats. VU rocks in this } \\
\text { zone were delineated because they exhibit dominantly northeast-southwest faulting and fracturing and } \\
\text { possess a different degree of alteration than VU rocks in the Yucca Mountain area. } \\
\text { This zone includes VU rocks in the Sarcobatus Flat area. VU rocks in this zone were delineated because } \\
\text { they exhibit various degrees of hydrothermal alteration. } \\
\text { K314VU_SAR } \\
\text { This zone includes VU rocks in the north and central part of the model domain in areas coincident with } \\
\text { Kawich Valley and Cactus and Gold Flats. This zone was delineated to include VU rocks associated } \\
\text { with the Cathedral Ridge and Kawich Ranges calderas. } \\
\text { This zone includes VU rocks in the northeast part of the model domain. This zone was delineated to } \\
\text { include a very thick, north-south-trending trough of volcanic rocks extending south from the Quinn } \\
\text { Canyon Range caldera. } \\
\text { This zone includes VU rocks in the vicinity of Stonewall Mountain and the Cactus Range, which are } \\
\text { physiographic features resulting from calderas. } \\
\text { This zone includes VU rocks in the Bullfrog Hills area, immediately west of Oasis Valley. This zone was } \\
\text { differentiated from the K314VU_SAR rocks because the apparent high degree of hydrothermal alter- } \\
\text { ation in this area results in extremely small hydraulic-conductivity rocks. }\end{array}$ \\
K318VU_BFH &
\end{tabular}




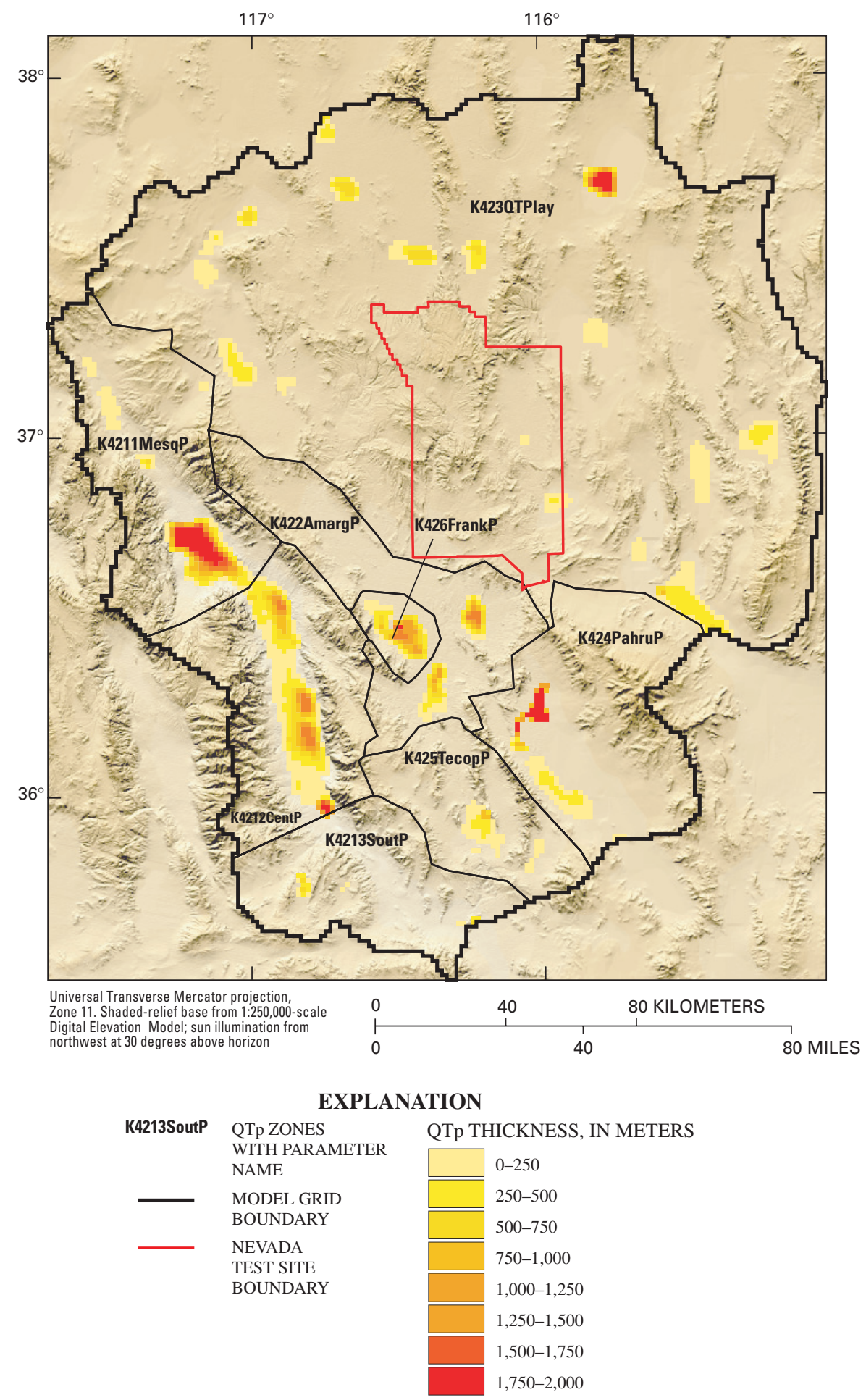

Figure 37. Definition of Quaternary-Tertiary playa deposits (QTp) hydraulicconductivity zone parameters and unit thickness. 


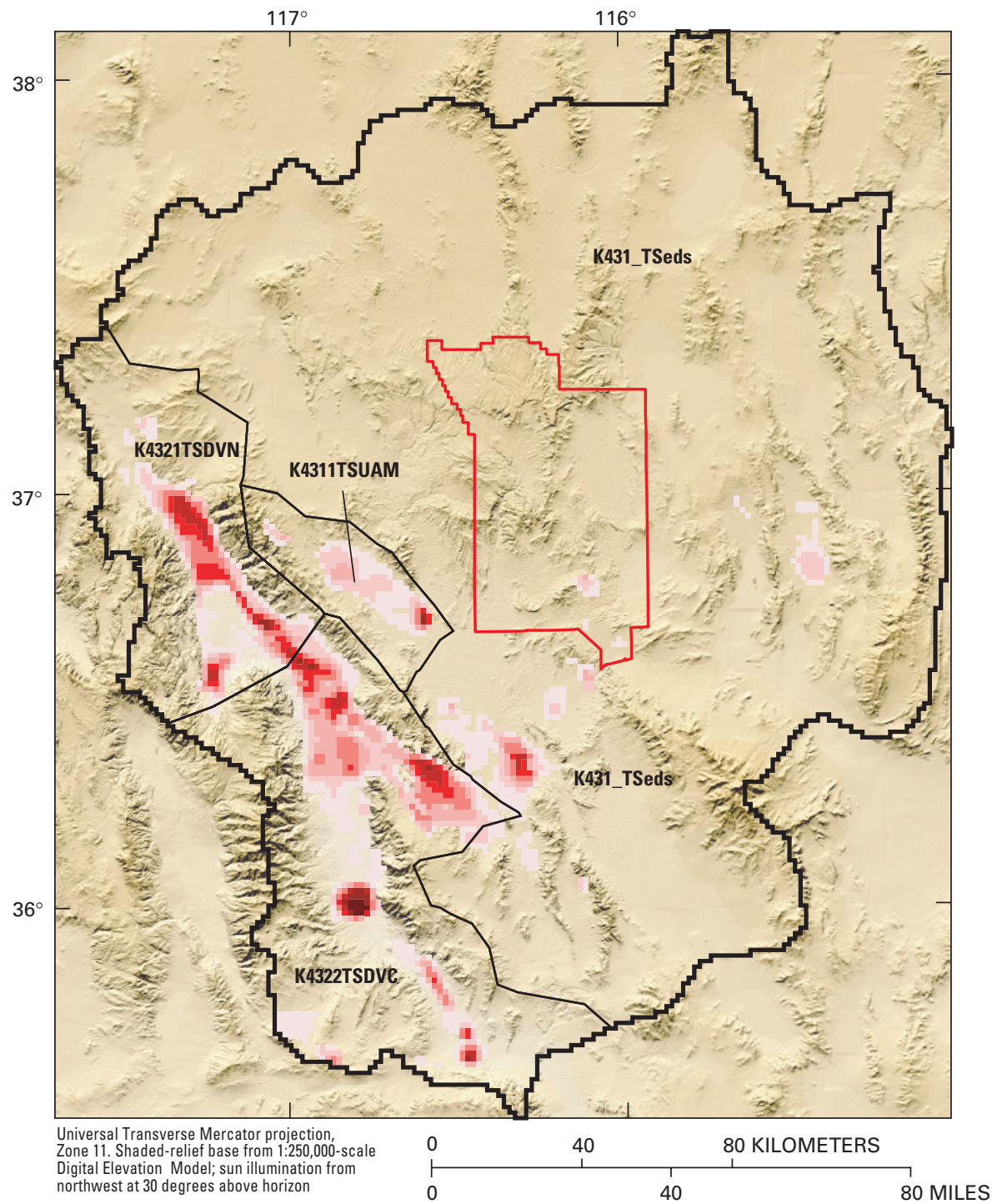

EXPLANATION

\begin{tabular}{|c|c|c|}
\hline \multirow[t]{9}{*}{ K4322TSDVC } & TSDVS ZONES & TSDVS THICKNESS, IN METERS \\
\hline & $\begin{array}{l}\text { WITH PARAMETER } \\
\text { NAME }\end{array}$ & $0-250$ \\
\hline & MODEL GRID & $250-500$ \\
\hline & BOUNDARY & $500-750$ \\
\hline & NEVADA & $750-1,000$ \\
\hline & BOUNDARY & $1,000-1,250$ \\
\hline & & $1,250-1,500$ \\
\hline & & $1,500-1,750$ \\
\hline & & $1,750-2,000$ \\
\hline
\end{tabular}

Figure 38. Definition of Tertiary sediments/Death Valley section (TSDVS) hydraulic-conductivity zone parameters and unit thickness. 


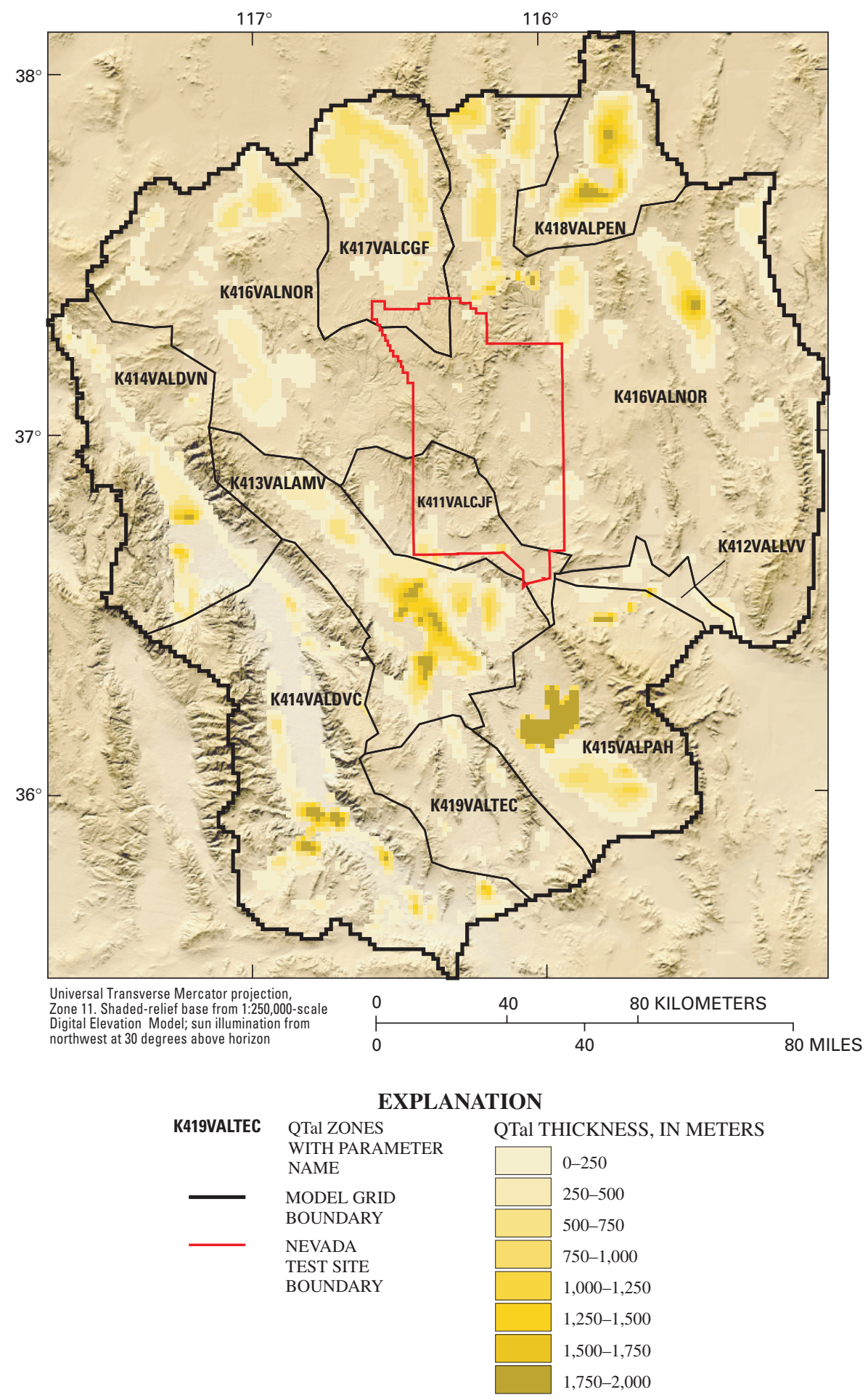

Figure 39. Definition of Quaternary-Tertiary valley-fill alluvium (QTal) hydraulicconductivity zone parameters and unit thickness. 
summary of how basin-fill parameters were subdivided is presented in table 14. Descriptions of QTal, QTp, and TSDVS parameters are presented in tables 25, 26, and 27.

\section{Vertical Anisotropy}

Vertical anisotropy parameters were initially defined for the major rock types. During the calibration process additional vertical anisotropy parameters were added for the UCA, LCA, QTp, QTal, TSDVS, and Timber Mountain/Pahute Mesa volcanic units. The sensitivity for these vertical anisotropy parameters was consistently low, and these parameters did not impact the simulation of heads and flows. Wide ranges of values were used for the vertical anisotropy parameters in attempts to better understand how they affected the flow system. The limited number of deep head observations and the regional model scale probably contributed to the low sensitivity of these parameters. Table 28 provides a brief description, parameter values, and CSS for the vertical anisotropy parameters.

\section{Horizontal Flow Barriers}

Many hydrogeologic features were simulated as horizontal flow barriers and evaluated (fig. 9 and table 6) to determine their sensitivity in the flow model. Ranges of values were used to define these HFB parameters in an effort to better understand how they affected the flow system. Many of these parameters had no apparent effect on the simulation of heads and flows and were subsequently assigned parameter

Table 25. Description of Quaternary-Tertiary valley-fill alluvium (QTal) horizontal hydraulic-conductivity parameters

Parameter name

K411VALCJF

K412VALLVV

K413VALAMV

K414VALDVN

K414VALDVC

K415VALPAH

K416VALNOR

K417VALCGF

K418VALPEN

K419VALTEC

\section{Description}

This zone includes the basin-fill deposits of Crater and Jackass Flats and Rock Valley. Basin-fill materials in these valleys are dominated by volcanic alluvium derived from Yucca Mountain, Skull Mountain, and surrounding areas. Some amounts of carbonate are derived from Bare Mountain and the Striped Hills areas. Locally the basin fill is known to be significantly interbedded with the tuff units. Also, in many areas the basin fill includes lava flows.

This zone includes the basin-fill units in and along the Las Vegas Valley shear zone. The zone is known to contain fine-grained materials associated with playas and late Tertiary and early Quaternary ground-water discharge areas. The zone is also likely to contain materials associated with the Las Vegas Valley fault that would potentially result in a mixture of basin-fill materials.

This zone includes the basin fill of the Amargosa Valley. It is differentiated from the other basin-fill materials because of its known high variability of unconsolidated and consolidated content, including fluvial, alluvial, and lacustrine deposits, heterogeneous debris flow and fan deposits, and volcanic tuffs, lava flows, and tuffaceous sediments.

This zone includes the basin fill of northern Death Valley, which contains a tremendous variety of materials derived from carbonate, clastic, granitic, volcanic, fluvial, and lacustrine sedimentary sources. It is highly variable, extremely high-energy colluvial material, interbedded with low-energy playa and eolian materials at Mesquite Flat.

This zone includes the basin fill of central Death Valley, which contains a tremendous variety of materials derived from carbonate, clastic, granitic, volcanic, fluvial, and lacustrine sedimentary sources. It is highly variable, extremely high-energy colluvial material, interbedded with low-energy playa materials at the edge of the Death Valley saltpan.

This zone includes the basin fill of Pahrump Valley, which is dominated by alluvial material derived from carbonate sources. In some areas, the basin fill contains locally high concentrations of materials derived from the Stirling quartzite that occurs in the Nopah Range.

This zone includes the basin fill of the northern part of the Death Valley region. In the eastern part of the zone, basin-fill materials are dominantly derived from carbonate rocks with minor amounts of clastic rocks. In the western part of the zone the alluvium is dominated by volcanic-derived alluvial materials and may also have interbeds of tuff and lava flows.

This zone is coincident with Cactus and Gold Flats. While somewhat similar to the other valleys in the western part of K416VALNOR zone, basin fill in this zone is noted for having somewhat noticeably higher amounts of silt.

This zone is coincident with the basin-fill units of Penoyer Valley. The zone was differentiated from K416VALNOR because of the difficulty maintaining hydraulic heads near the Penoyer playa. This may suggest that these basin-fill materials contain more fine-grained materials similar to those in Cactus and Gold Flats.

This zone includes basin-fill material in the Tecopa/Shoshone area. These basin-fill units contain significant amounts of lacustrine materials associated with pluvial Lake Tecopa. 
Table 26. Description of Quaternary-Tertiary playa deposits (QTp) horizontal hydraulic-conductivity parameters

\begin{tabular}{|c|c|}
\hline Parameter name & Description \\
\hline K4211MesqP & $\begin{array}{l}\text { This zone includes the Quaternary playa materials occupying Mesquite Flat. This playa at the extreme } \\
\text { north end of Death Valley includes a significant amount of fine-grained material, but also has a } \\
\text { considerably high content of eolian sand and silt. }\end{array}$ \\
\hline K4212CentP & $\begin{array}{l}\text { This zone includes Cottonball, Middle, and Badwater Basins on the Death Valley saltpan. The playa is } \\
\text { dominantly silt and clay, containing extremely large amounts of salt. }\end{array}$ \\
\hline K4213SoutP & $\begin{array}{l}\text { This zone contains playa materials at the extreme south end of Death Valley. These units are not as } \\
\text { heavily laden with salts as the area to the north. The playa materials are high in silt and clay. This area } \\
\text { is different from the Mesquite Flat playa because it does not contain as much sand as the Mesquite } \\
\text { playa area. }\end{array}$ \\
\hline K422AmargP & $\begin{array}{l}\text { This zone includes the playas of the Amargosa Valley including Amargosa Flat (Peter's Playa) and } \\
\text { Alkali Flat (Franklin Lake). These materials are either present-day or past ground-water discharge } \\
\text { areas and contain large quantities of clay, salt and(or) spring carbonates. They can be differentiated } \\
\text { from the playas in Death Valley because they do not contain the extremely high quantities of salt as } \\
\text { those deposits; however, the Amargosa Valley ground-water-discharging playas contain considerably } \\
\text { different fine-grained materials than the dry lake-bed playas of the remainder of the model area. }\end{array}$ \\
\hline K423QTPlay & $\begin{array}{l}\text { This zone includes the dominantly dry playas of the Death Valley region. These playas are characterized } \\
\text { by the high quantities of fine-grained silt and clay that they contain. }\end{array}$ \\
\hline K424PahruP & $\begin{array}{l}\text { This zone includes the wet, ground-water-discharging playas of Pahrump Valley. These playas represent } \\
\text { present-day discharging playas and are interpreted as having large quantities of clay, silt, and salt, and } \\
\text { some spring deposits. }\end{array}$ \\
\hline K425TecopP & $\begin{array}{l}\text { This zone includes the lake beds of pluvial Lake Tecopa. These playa units are differentiated from other } \\
\text { past- and present-day playa/lake beds because they contain large quantities of water-laid ash-fall } \\
\text { materials. }\end{array}$ \\
\hline K426FrankP & $\begin{array}{l}\text { This zone includes playa units in the Franklin Well area of the Amargosa Valley. It is differentiated from } \\
\text { other playa units in the Amargosa Valley because it contains a large amount of paludal and lacustrine } \\
\text { deposits. }\end{array}$ \\
\hline
\end{tabular}

Table 27. Description of Tertiary sediments/Death Valley section (TSDVS) horizontal hydraulic-conductivity parameters

\begin{tabular}{ll}
\hline \multicolumn{1}{c}{ Parameter name } & Description \\
\hline K431_Tseds & $\begin{array}{c}\text { This zone includes the Tertiary sedimentary rocks that occur dominantly in the Amargosa Valley and to } \\
\text { the east of the Nevada Test Site. These hydrogeologic units include mostly lithified, or consolidated, } \\
\text { alluvial fan deposits. In some cases they may include lacustrine limestone deposits and water-laid } \\
\text { tuffaceous sediments. } \\
\text { This zone includes the Tertiary sedimentary units in the northwestern part of the Amargosa Valley imme- } \\
\text { diately south of the Bullfrog Hills and west of Bare Mountain. These units are interpreted as } \\
\text { containing larger quantities of clastic-derived, lithified fanglomerate material. } \\
\text { This zone includes the Tertiary sedimentary rocks in northern Death Valley in the vicinity of Mesquite } \\
\text { Flat, Grapevine Springs, and Ubehebe Crater. These typically low-permeability rocks are quite vari- } \\
\text { able and contain alluvial, fluvial, lacustrine, and tuffaceous sedimentary materials. } \\
\text { This zone includes the Tertiary sedimentary rocks in central Death Valley in the vicinity of Furnace } \\
\text { Creek Wash. The dominant formations of this hydrogeologic unit include the Artist Drive Formation, } \\
\text { the Furnace Creek Formation, and the Funeral Formation. These typically low-permeability rocks are } \\
\text { quite variable and contain alluvial, fluvial, lacustrine, and tuffaceous sedimentary materials. }\end{array}$ \\
K4322TSDVC &
\end{tabular}


Table 28. Vertical anisotropy parameter descriptions, values, and composite scaled sensitivities

\begin{tabular}{lllc}
\hline \multicolumn{1}{c}{$\begin{array}{c}\text { Parameter } \\
\text { name }\end{array}$} & \multicolumn{1}{c}{ Description } & $\begin{array}{c}\text { Param- } \\
\text { eter } \\
\text { value } \\
\left(\mathbf{K}_{\mathbf{h}} \mathbf{/} \mathbf{K}_{\mathbf{v}} \mathbf{)}\right.\end{array}$ & $\begin{array}{c}\text { Composite scaled } \\
\text { sensitivity }\end{array}$ \\
\hline K1_VANI & Vertical anisotropy for pCgm, TJi, UCCU, and LCCU & 1 & 1.79 \\
K2CARBVUCA & Vertical anisotropy for UCA & 3 & $7.86 \times 10^{-5}$ \\
K2CARBVLCT & Vertical anisotropy for LCA thrust units & 4.53 & $1.57 \times 10^{-2}$ \\
K2CARBVLCA & Vertical anisotropy for LCA & 4 & 0.193 \\
K3_VOLVANI & Vertical anisotropy for VU, VA, and VCU & 0.960 & $4.41 \times 10^{-2}$ \\
K31TBAVANI & Vertical anisotropy for TBA & 1 & $4.59 \times 10^{-3}$ \\
K32TBCVANI & Vertical anisotropy for TBCU & 1 & $5.77 \times 10^{-3}$ \\
K33TBQVANI & Vertical anisotropy for TBQ & 1 & $1.81 \times 10^{-3}$ \\
K34TCBVANI & Vertical anisotropy for TCB & 1 & $4.30 \times 10^{-3}$ \\
K35TCVANI & Vertical anisotropy for TC & 1 & $1.23 \times 10^{-2}$ \\
K36TMAVANI & Vertical anisotropy for TMA & 1 & $5.57 \times 10^{-2}$ \\
K4VANIQTAL & Vertical anisotropy for QTal & 1 & $5.71 \times 10^{-2}$ \\
K4VANIQTP & Vertical anisotropy for QTp & 1 & $7.81 \times 10^{-2}$ \\
K4VANITSDV & Vertical anisotropy for TSDVS & 1 & 0.229 \\
\hline
\end{tabular}

values of 1.0, which effectively removed them as flow barriers. Other HFB parameters were defined and assigned values to better represent changes in hydraulic conductivity (table 29).

\section{Observation Data Review and Reweighting}

During the model-calibration process, hydraulic-head and ground-water-discharge observations and corresponding weights were evaluated to determine if they appropriately constrained the flow model. In some cases, these model constraints, which were originally thought to be representative of predevelopment regional ground-water conditions, were modified.

Modifications to hydraulic-head observations involved either removing hydraulic-head observations or increasing standard deviations used to calculate observation weights. Hydraulic-head observations were removed when reinspection of the data resulted in a required change to the UseFlag (see "HydraulicHead Observations" section). In many cases, the authors concluded that some weights were unrealistically large (particularly those with standard deviations between 0 and $5 \mathrm{~m}$ ), particularly when considering the inherent model error associated with a regional-scale simulation with grid cells of $1,500 \mathrm{~m}$ on the side. In some cases, the initial standard deviations (fig. 20) were determined to be unrealistic and were increased, particularly in large hydraulic gradient areas where model error would be apparent. Throughout the model, standard deviations were increased to a minimum of $3 \mathrm{~m}$. The distribution of hydraulic-head standard deviations in the calibrated model more appropriately reflects the potential for model error, and most standard deviations are in the 3- to 10-m range (fig. 20).

Modifications also were made to ground-waterdischarge observation coefficients of variation during the calibration process. Ground-water discharge observations, however, were not modified. The approach used to determine coefficients of variation may not have adequately considered all sources of observation error. Model error, discharge-estimation methods, and magnitude of discharge rate were considered during the calibration process and, where necessary, revised coefficients of variation were modified to reflect (1) the cumulative error, (2) the relative observation importance, and (3) the confidence in the observation.

Because of the regional scale of the flow model, some hydrologic and geologic features were generalized. For example, many discharge areas represent individual springs that are significantly smaller in area than the simulated $1,500-\mathrm{m}$ by $1,500-\mathrm{m}$ grid. Small-scale features such as localized variations in hydraulic-head gradient, fault and fracture geometry, and abrupt lithology changes influence ground-water discharge rates. It was not possible to explicitly represent these types of features in the regional-scale model, and errors in simulation resulted. 
Table 29. Horizontal flow barrier parameter values and composite scaled sensitivities

\begin{tabular}{|c|c|c|}
\hline $\begin{array}{c}\text { Parameter } \\
\text { name }\end{array}$ & $\begin{array}{l}\text { Conductance, } \\
\text { in meters } \\
\text { squared per day }\end{array}$ & $\begin{array}{l}\text { Composite } \\
\text { scaled } \\
\text { sensitivity }\end{array}$ \\
\hline HFB_CDVFCF & 1 & $1.35 \times 10^{-6}$ \\
\hline HFB_DeathV & 1 & $8.59 \times 10^{-6}$ \\
\hline HFB_IndSpr & $2.67 \times 10^{-6}$ & 0.158 \\
\hline HFB_KeaneW & 1 & $5.66 \times 10^{-7}$ \\
\hline HFB_LVVSZ & $1.00 \times 10^{-7}$ & 0.125 \\
\hline HFB_NDVFCF & 1 & $2.22 \times 10^{-6}$ \\
\hline HFB_Pahute & 1 & $8.75 \times 10^{-6}$ \\
\hline HFBAmargos & $1.45 \times 10^{-6}$ & $6.61 \times 10^{-2}$ \\
\hline HFBAshMead & $1.00 \times 10^{-4}$ & $7.03 \times 10^{-2}$ \\
\hline HFBBareMtn & $1.00 \times 10^{-3}$ & $2.40 \times 10^{-7}$ \\
\hline HFBBareMtF & $1.00 \times 10^{-5}$ & 0.536 \\
\hline HFBEagleMt & $1.00 \times 10^{-5}$ & $1.75 \times 10^{-3}$ \\
\hline HFBCraterF & 1 & $2.56 \times 10^{-5}$ \\
\hline HFBFurnace & 1 & $1.23 \times 10^{-5}$ \\
\hline HFBGravity & $1.00 \times 10^{-6}$ & $8.54 \times 10^{-2}$ \\
\hline HFBHwy95 & $1.00 \times 10^{-5}$ & 0.156 \\
\hline HFBSaratog & $1.00 \times 10^{-6}$ & $6.87 \times 10^{-3}$ \\
\hline HFBPahrump & $1.00 \times 10^{-5}$ & 0.227 \\
\hline HFBStewart & $1.00 \times 10^{-3}$ & $4.07 \times 10^{-2}$ \\
\hline HFBRestSpr & 1 & $6.26 \times 10^{-5}$ \\
\hline HFBSolitar & $1.00 \times 10^{-9}$ & $4.34 \times 10^{-4}$ \\
\hline HFBТесора & 1 & $9.06 \times 10^{-6}$ \\
\hline HFBTecPass & 1 & $5.48 \times 10^{-7}$ \\
\hline HFB_Eleana & $1.00 \times 10^{-9}$ & $4.50 \times 10^{-2}$ \\
\hline HFB_NCFYM & 1 & $4.57 \times 10^{-5}$ \\
\hline HFBBulfrog & $1.00 \times 10^{-6}$ & 0.378 \\
\hline
\end{tabular}

Similarly, discharge areas with flow less than $1,000 \mathrm{~m}^{3} / \mathrm{d}$ were difficult to simulate. These discharge areas are relatively minor considering the overall volumetric budget and model scale. In some cases, a small volumetric discharge from a discrete spring may be the most accurately measured in the system; however, model error could be equivalent to or larger than the flow magnitude. To address this issue, coefficients of variation of 50 or 100 percent were assigned to flow observations that were less than $1,000 \mathrm{~m}^{3} / \mathrm{d}$. A 100-percent error for these small-volume discharge areas was considered acceptable for a regional-scale model.

In some cases, individual springs such as Travertine, Texas, and Nevares Springs were simulated. Measurement or estimation of these springs also has associated error. For example, a discharge measure- ment at a discrete, single-orifice spring with a defined channel can be measured within 3 to 5 percent of the actual flow (Rantz, 1982). Many springs in the region, however, have diffuse, bifurcating discharges that are more difficult to measure and have measurement errors of 10 percent or greater. Small discharge seeps, also common in the DVRFS (for example, Grapevine Springs), are even more difficult to quantify and are often estimated with errors of at least 50 percent.

\section{Model Evaluation}

After calibration, the DVRFS model was evaluated to assess the likely accuracy of simulated results. An advantage of calibrating the DVRFS model using nonlinear regression is that there exists a substantial methodology for model evaluation that facilitates a better understanding of model strengths and weaknesses. A protocol exists to evaluate the likely accuracy of simulated hydraulic heads and ground-water discharge, estimated and not estimated parameter values and associated sensitivities and confidence intervals, and other measures of parameter and prediction uncertainty.

\section{Evaluation of Simulated Hydraulic Head and Ground-Water Discharge}

The values matched by the regression (the elements of vector $y$ of equation 1) initially included 732 measured hydraulic-head and 46 measured ground-water-discharge observations. During calibration, 73 hydraulic-head observations were removed from the data set because of obvious errors revealed during closer evaluation and 7 head observations were added from recently drilled boreholes; thus, 666 head observations were matched in the final regression. Matching each of the 46 measured ground-water discharges during calibration was difficult. However, matching these 46 groups of ground-water discharges was more appropriate than attempting to match discharge at each of the 903 independent model cells that make up the ground-water discharge groups. Ultimately, 46 ground-water discharge observations, along with 666 hydraulic-head observations discussed above, were used as observations in the regression. 


\section{Evaluation of Model Fit}

Unweighted and weighted residuals (defined after equation 1) are important indicators of model fit and, depending somewhat on data quality, model accuracy. Consideration of unweighted residuals is intuitively appealing because the values have the dimensions of the observations and indicate, for example, that a hydraulic head is matched to within $10 \mathrm{~m}$. Unweighted residuals can, however, be misleading because observations are measured with different accuracy.

Weighted residuals demonstrate model fit relative to what is expected in the calibration based on the precision, or noise, of the data. They are less intuitively appealing because they are dimensionless quantities that equal the number of standard deviations or coefficients of variation needed to equal the unweighted residual.

Unweighted hydraulic-head residuals tended to be larger in areas with moderate to large hydraulic gradients than in areas with flat gradients, so these three types of areas are discussed separately. In areas of relatively flat hydraulic gradients, the largest unweighted residuals have absolute values less than $20 \mathrm{~m}$ and are commonly less than $10 \mathrm{~m}$. In areas of moderate hydraulic gradients, the differences between simulated and observed heads are sometimes larger (as large as $50 \mathrm{~m}$ ); however, they are commonly less than $20 \mathrm{~m}$. In areas of large hydraulic gradients, the difference between simulated and observed heads can exceed $100 \mathrm{~m}$ (although that occurrence is rare); however, the simulated gradients are similar to the gradients evident from the data. The match is good considering the over 2,000-m difference in hydraulic head across the model domain and the size of the grid relative to the width of some of the steep hydraulic gradients.

Matching ground-water discharges was difficult but provided important information to the calibration. Indeed, it would not have been possible to support the complex representation of the system produced through the calibration without the ground-water discharge data. The sum of all simulated ground-water discharge is $286,800 \mathrm{~m}^{3} / \mathrm{d}$; the sum of estimated, or observed, ground-water discharge is $295,500 \mathrm{~m}^{3} / \mathrm{d}$ (table 30). As a result, simulated total ground-water discharge is within about 3 percent of observed.

When weighted as described above, $S(\underline{b})$ for heads equals 6,178 , for flows it is 395 , and the total is
6,573 . The standard error of the regression equals 3.1, which indicates that overall model fit is consistent with head standard deviations that are 3.1 times the assigned values. For flow, overall model fit is consistent with 3.1 times the assigned coefficients of variation of 10 to 100 percent. Thus, effective model fit is between 31 and 310 percent.

\section{Spatial Distribution of Unweighted and Weighted Residuals}

Comparison of simulated hydraulic heads with the potentiometric surface map developed by D'Agnese and others (1998) indicates that the DVRFS model results depict major features of the head distribution well. In general, areas of flat and large hydraulic gradients are appropriately located. A more detailed evaluation of simulated hydraulic heads can be obtained through inspection of maps of residuals.

Unweighted residuals for hydraulic heads were plotted to show their spatial distribution (fig. 40).

Good fit to observed hydraulic heads (residuals with absolute values less than $10 \mathrm{~m}$ ) generally occurs in areas of flat hydraulic gradients; moderate fit to observed heads (residuals with absolute values of 10 to $20 \mathrm{~m}$ ) occurs in the remainder of the flat hydraulic gradient areas. Poorer fit to observed heads (residuals with absolute values of greater than $20 \mathrm{~m}$ ) appears to occur in large hydraulic gradient areas. Poorest fit to observed hydraulic heads occurs in the vicinity of Indian Springs, western Yucca Flat, and the southern Bullfrog Hills. Most of these inaccuracies can be attributed to (1) insufficient representation of the hydrogeology in the HFM, (2) misinterpretation of water levels, and (3) model error associated with grid cell size.

Weighted head residuals are plotted in figure 41. Patterns in the spatial distribution of weighted residuals indicate a nonrandom distribution and suggests that model error exists. Simulated heads in northwestern Cactus Flat, southern Railroad Valley, and Desert Valley are consistently higher than observed; however, all of these areas are close to model boundaries, and existing data are of poorer quality than in the remainder of the model domain. In the northwestern part of the Amargosa Valley, simulated heads are lower than observed nearer to the Bullfrog Hills and higher than observed farther south, suggesting some bias. For the remainder of the model, in areas of concentrated head observations there appear to be 
Table 30. Water budget for the simulated values in the calibrated model compared with estimates from this study

[Values rounded to the nearest $100 \mathrm{~m} 3 / \mathrm{d} ; \mathrm{m}^{3} / \mathrm{d}$, cubic meters per day; $\sim$, approximate; $<$, less than]

\begin{tabular}{|c|c|c|}
\hline Water budget component & $\begin{array}{l}\text { Simulated } \\
\left(\mathrm{m}^{3} / \mathrm{d}\right)\end{array}$ & $\begin{array}{l}\text { Estimated } \\
\qquad\left(\mathrm{m}^{3} / \mathrm{d}\right)\end{array}$ \\
\hline \multicolumn{3}{|l|}{ FLOW IN } \\
\hline Constant Head & 49,500 & $\sim 23,400$ \\
\hline Mud Lake & 23,000 & 3,400 \\
\hline Cactus Flat & 25,500 & Unknown \\
\hline Pahranagat Lakes & 1,000 & $\sim 20,000$ \\
\hline Recharge & 266,800 & $<969,200$ \\
\hline TOTAL FLOW IN & 316,300 & $<992,600$ \\
\hline \multicolumn{3}{|l|}{ FLOW OUT } \\
\hline Constant Head & 29,700 & $\sim-23,400$ \\
\hline Pahranagat Lakes & 22,400 & $\sim-20,000$ \\
\hline Salt Creek & 800 & Unknown \\
\hline Mud Lake & 6,500 & $-3,400$ \\
\hline Discharge & 286,800 & 295,500 \\
\hline $\begin{array}{c}\text { Ash Meadows } \\
(\mathrm{G}-\mathrm{AM}-*)\end{array}$ & 60,400 & 60,800 \\
\hline $\begin{array}{r}\text { Oasis Valley } \\
(\mathrm{G}-\mathrm{OV}-*)\end{array}$ & 20,400 & 19,400 \\
\hline $\begin{array}{l}\text { Tecopa basin } \\
\text { (G-TC-*) }\end{array}$ & 12,900 & 21,300 \\
\hline $\begin{array}{l}\text { Shoshone basin } \\
\quad(\mathrm{G}-\mathrm{SHOSH}-*)\end{array}$ & 10,000 & 7,100 \\
\hline $\begin{array}{l}\text { Sarcobatus Flat } \\
\quad(\text { G-SARCO-*) }\end{array}$ & 47,200 & 43,900 \\
\hline $\begin{array}{l}\text { Franklin Well } \\
\text { (G-FRANKWEL) }\end{array}$ & 1,000 & 1,200 \\
\hline $\begin{array}{l}\text { Franklin Lake } \\
\qquad(\text { G-FRNKLK-*) }\end{array}$ & 6,200 & 3,400 \\
\hline $\begin{array}{l}\text { Chicago Valley } \\
\text { (G-CHIGAGOV) }\end{array}$ & 3,600 & 1,500 \\
\hline $\begin{array}{l}\text { Indian and Corn Creek } \\
\text { Springs } \\
\text { (G-INDIANSP, } \\
\text { G-CORNCREK) }\end{array}$ & 4,400 & 2,900 \\
\hline $\begin{array}{l}\text { Grapevine Springs } \\
\text { (G-GRAPE-*) }\end{array}$ & 4,400 & 3,500 \\
\hline $\begin{array}{l}\text { Death Valley } \\
\qquad(\mathrm{G}-\mathrm{DV}-*)\end{array}$ & 77,200 & 92,200 \\
\hline $\begin{array}{l}\text { Penoyer Valley } \\
\text { (G-PENOYERV) }\end{array}$ & 2,100 & 12,800 \\
\hline $\begin{array}{l}\text { Stewart and Pahrump } \\
\text { Valleys } \\
\text { (G-STEWRT-*, } \\
\text { G-PAH-*) }\end{array}$ & 37,000 & 25,500 \\
\hline TOTAL FLOW OUT & 316,500 & $\sim 272,100$ \\
\hline FLOW IN - FLOW OUT & -200 & -- \\
\hline
\end{tabular}

residuals that are both greater than and less than expected, suggesting a random distribution of weighted head residuals.

Ground-water discharge residuals are plotted in figure 42 along with the range of probable error associated with the observation. Residuals are calculated as observed minus simulated, and ground-water discharge has a negative sign convention. As simulated, the model appears to have a fairly random distribution of residuals with a slight bias toward being negative, indicating that simulated flows in these areas are less than observed flows. The largest unweighted ground-water discharge residuals occur at Ash Meadows (northern and central area), Sarcobatus Flat (northeastern area), Death Valley (Badwater and Cottonball Basins, Furnace Creek fan, and western alluvial fans), Penoyer Valley, and Pahrump Valley (near Manse Spring). The two major discharge areas that would contribute the largest volumetric error to the model are Ash Meadows and Death Valley. Ash Meadows (central area) is also one of the largest discharging sites in the DVRFS flow model; therefore, moderate percentages of error in the simulated discharge could result in comparatively large volumetric errors. While Death Valley is of concern, the ground-water discharge observations used in the DVRFS model are preliminary and should not be considered authoritative values of discharge from the Death Valley saltpan.

The plot of ground-water discharge residuals gives a better representation of how well the model matched ground-water discharge observations. This plot shows the acceptable range of error in the simulated ground-water discharge. In other words, simulated discharges within this range are acceptable because they are within the observation error. In most cases, simulated small-volume ground-water discharge values are within, or quite close to, the acceptable range. Some large-volume ground-water discharge areas at Ash Meadows, Oasis Valley, Tecopa, Pahrump, and Death Valley, however, are not discharging expected volumes (fig. 42) and, in one case at Death Valley (Cottonball Basin), there is a discharge of 9 times the expected volumetric error. The discharges for each individual discharge observation, however, appear to be randomly distributed within the larger, regional ground-water discharge area. Total ground-water discharge from these regional ground-water discharge areas appears to adequately represent natural conditions in each major discharge 


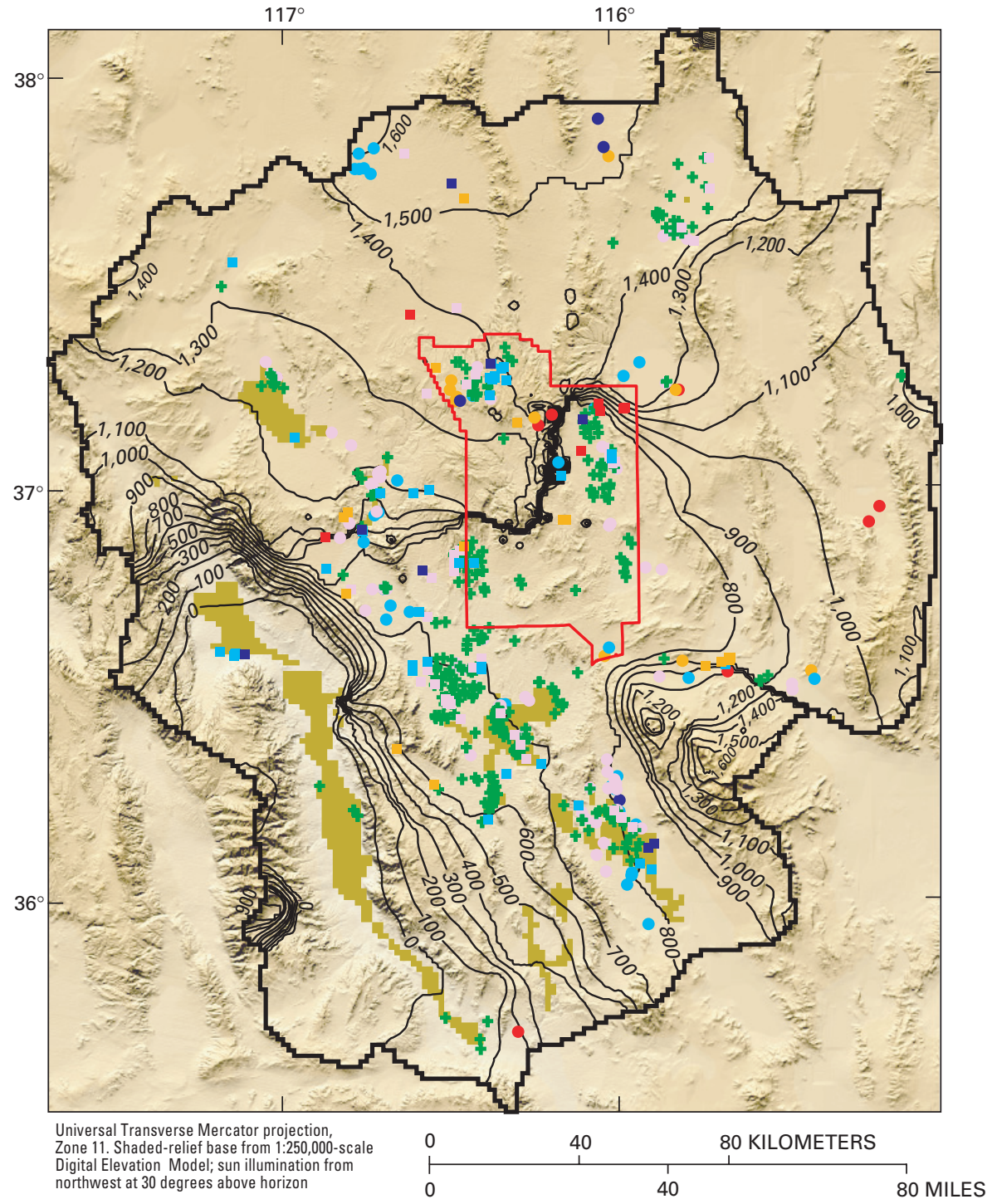

\section{EXPLANATION}

\begin{tabular}{|c|c|}
\hline \multirow[t]{2}{*}{$=$} & DRAIN CELLS \\
\hline & $\begin{array}{l}\text { MODEL GRID } \\
\text { BOUNDARY }\end{array}$ \\
\hline & $\begin{array}{l}\text { NEVADA TEST SITE } \\
\text { BOUNDARY }\end{array}$ \\
\hline$-100-$ & $\begin{array}{l}\text { SIMULATED HYDRAULIC- } \\
\text { HEAD CONTOUR-Contour } \\
\text { interval is } 100 \text { meters. Datum } \\
\text { is sea level }\end{array}$ \\
\hline
\end{tabular}

HYDRAULIC-HEAD RESIDUALS, IN METERS

- GREATER THAN 100

-10 $50-100$

- $35-50$

- $20-35$

- $10-20$

$+-10-10$

$-20--10$

$-35--20$

$-50--35$

$-100--50$

- LESS THAN -100

Figure 40. Hydraulic-head residuals (observed minus simulated) and simulated potentiometric surface for model layer 1 . 

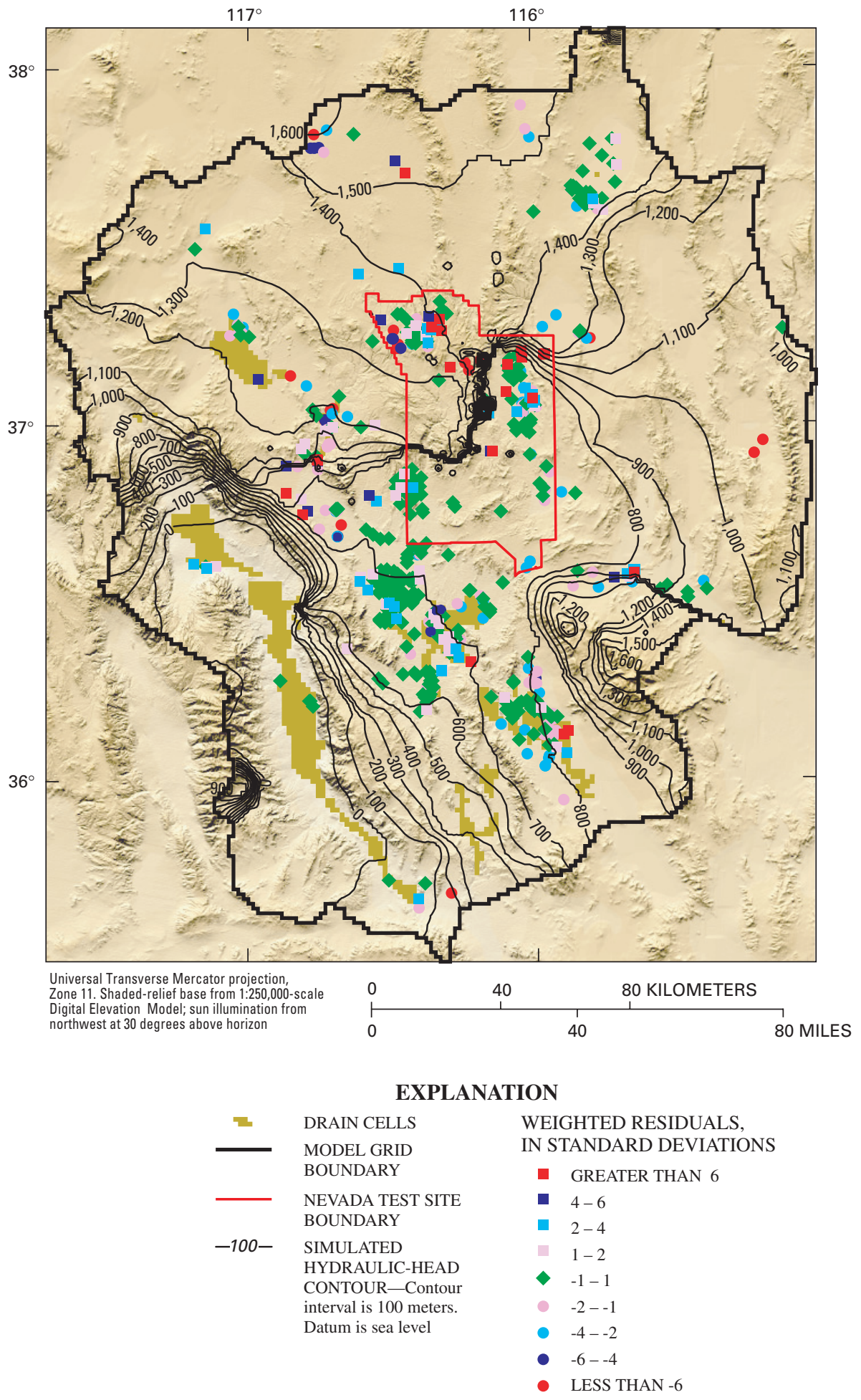

Figure 41. Hydraulic-head weighted residuals (observed minus simulated) and simulated potentiometric surface for model layer 1 . 


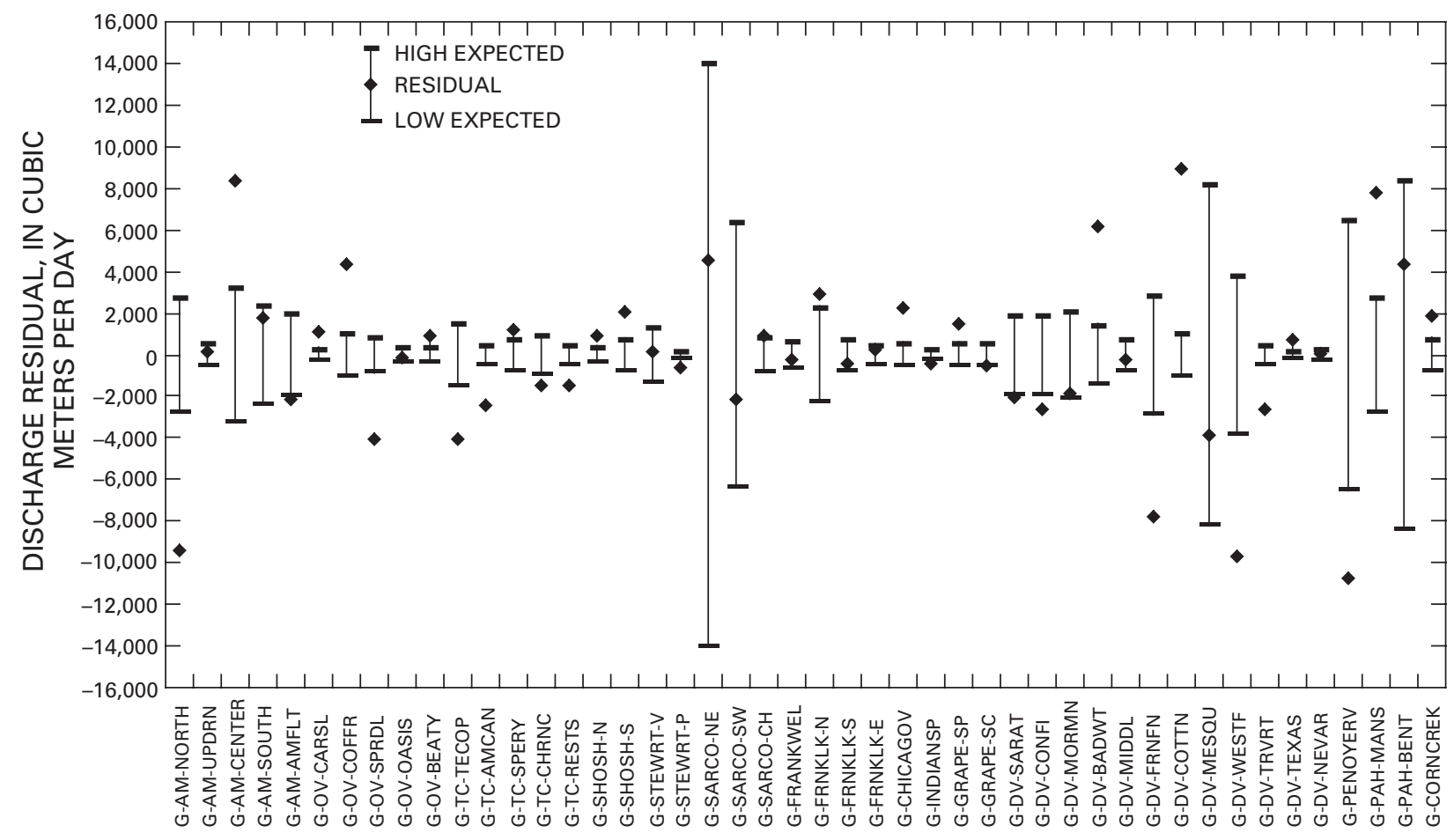

OBSERVATION NAME

Figure 42. Ground-water discharge residuals (observed minus simulated) with expected observed discharge variation.

area (fig. 43). Discharge estimates range from $1,200 \mathrm{~m}^{3} / \mathrm{d}$ in the Franklin Well area to $92,200 \mathrm{~m}^{3} / \mathrm{d}$ at Death Valley. Differences between these estimates and those presented in other reports are discussed in Laczniak and others (2001). Observed and simulated ground-water discharge and weighted residuals for ground-water discharge are presented in figs. 44 and 45 .

\section{Distribution of Weighted Residuals Relative to Weighted Simulated Values}

To evaluate model results for systematic model error or errors in assumptions concerning observations and weights, weighted residuals are plotted against weighted simulated values for head and ground-waterdischarge observations. Ideally, weighted residuals will vary randomly about zero regardless of the simulated value.

Figure 46 shows that most of the weighted residuals for hydraulic heads in the DVRFS model vary randomly about a value of zero. Four values are greater than +9.3 , which is three times the regression standard error of 3.1; eleven values are less than -9.3 . For normally distributed values only 3 in 1,000, on average, would be so different from the expected value. While this distribution is slightly biased by several large negative values, the distribution is still largely random. In previous modeling investigations, the large negative values were attributed to wells occurring in areas of potentially perched water levels or in areas where the model could not represent large hydraulic gradients. The same observations are apparent in the current DVRFS model.

The weighted residuals for ground-water discharges shown in figure 46 appear to vary randomly about a value of zero. None of the weighted residuals for ground-water discharges are greater than 9.3 or less than -9.3 , indicating that all the flow residuals are within three times the regression standard error.

\section{Normality of Weighted Residuals and Model Linearity}

The normality of the weighted residuals and model linearity are important to the use of measures of parameter and prediction uncertainty, such as linear confidence intervals. Specifically, the weighted residuals need to be normally distributed and the model needs to be effectively linear for the calculated linear confidence intervals on estimated parameters and 


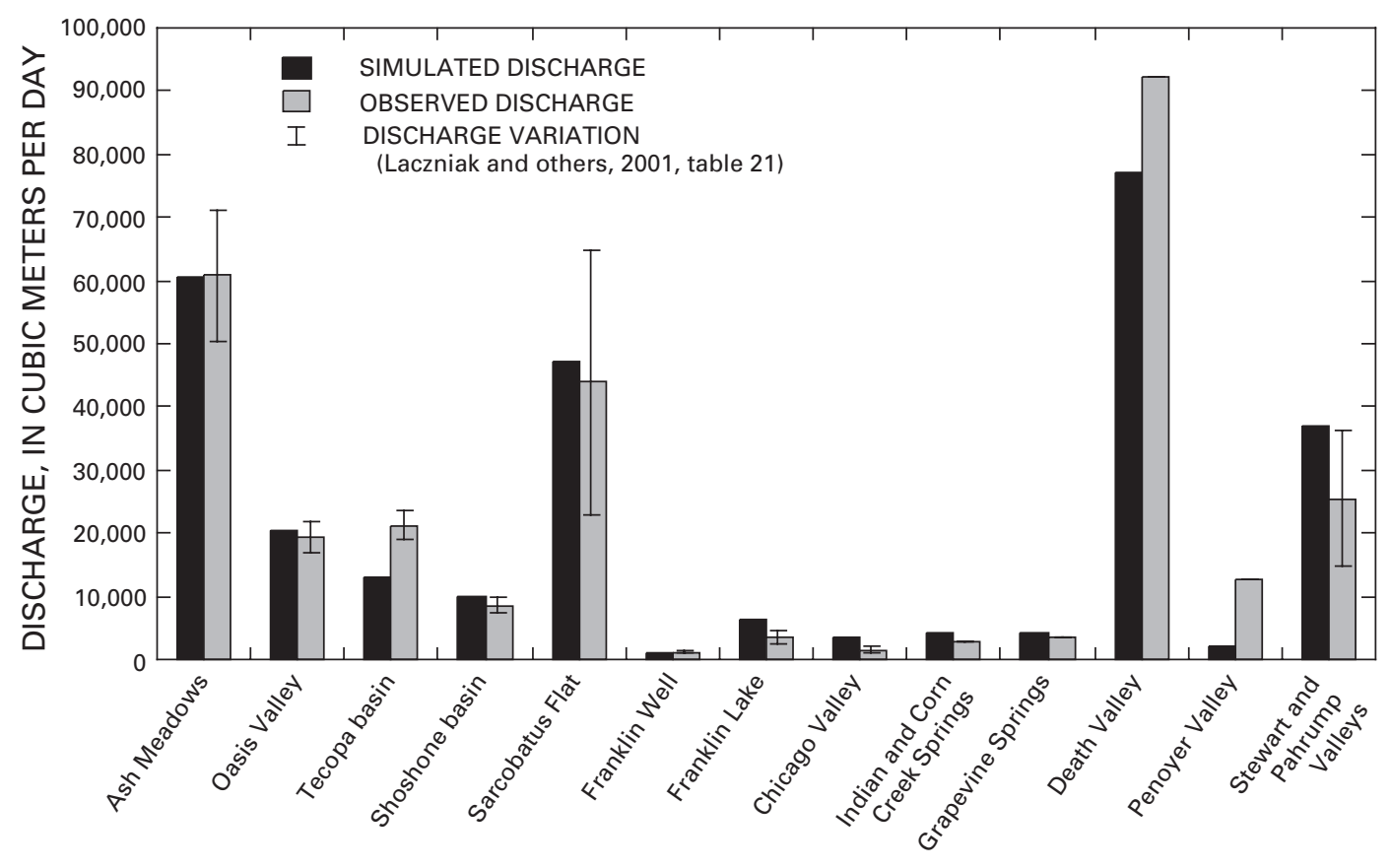

MAJOR DISCHARGE AREAS

Figure 43. Simulated and observed ground-water discharge for major discharge areas.

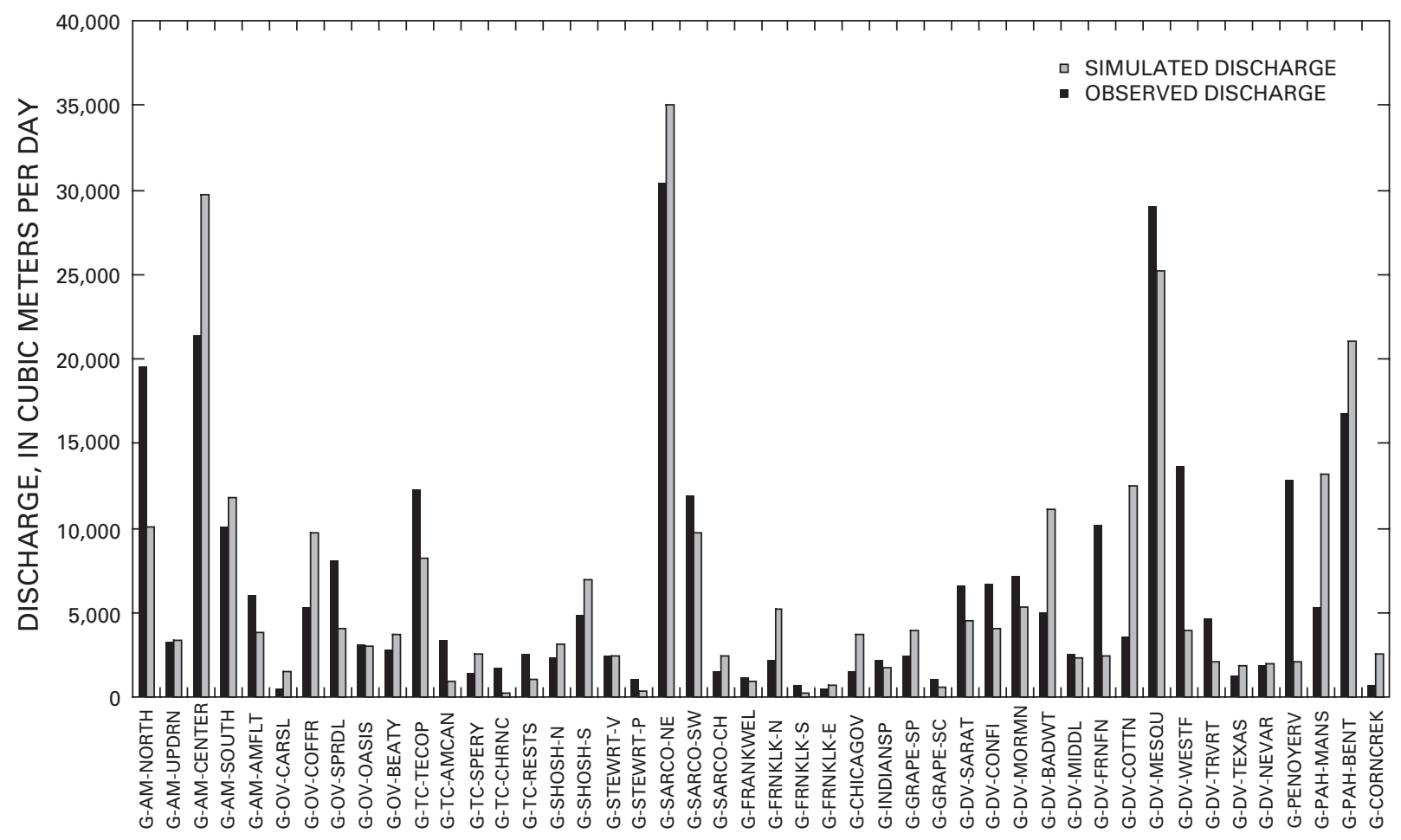

\section{OBSERVATION NAME}

Figure 44. Observed and simulated ground-water discharge. 


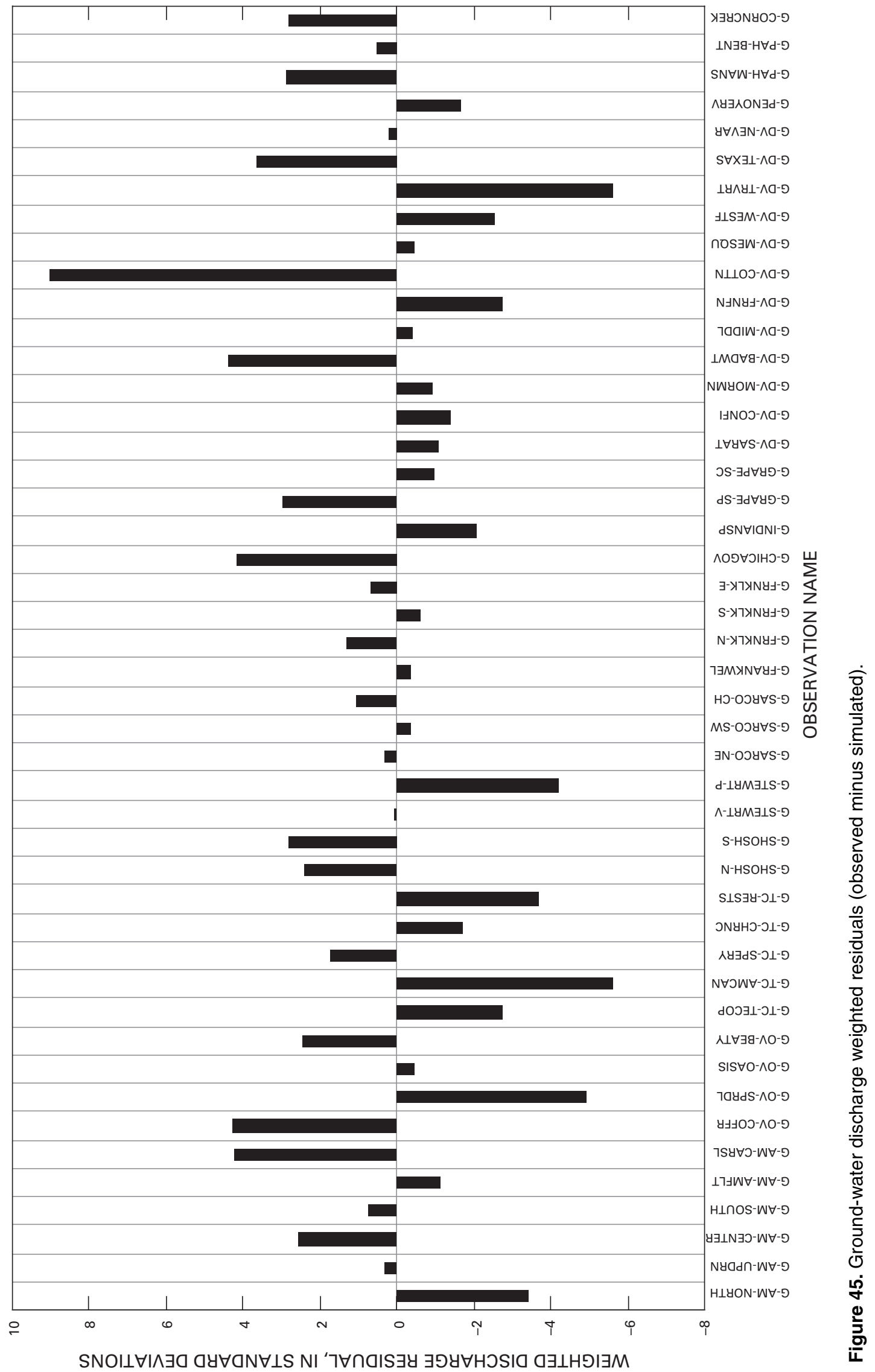




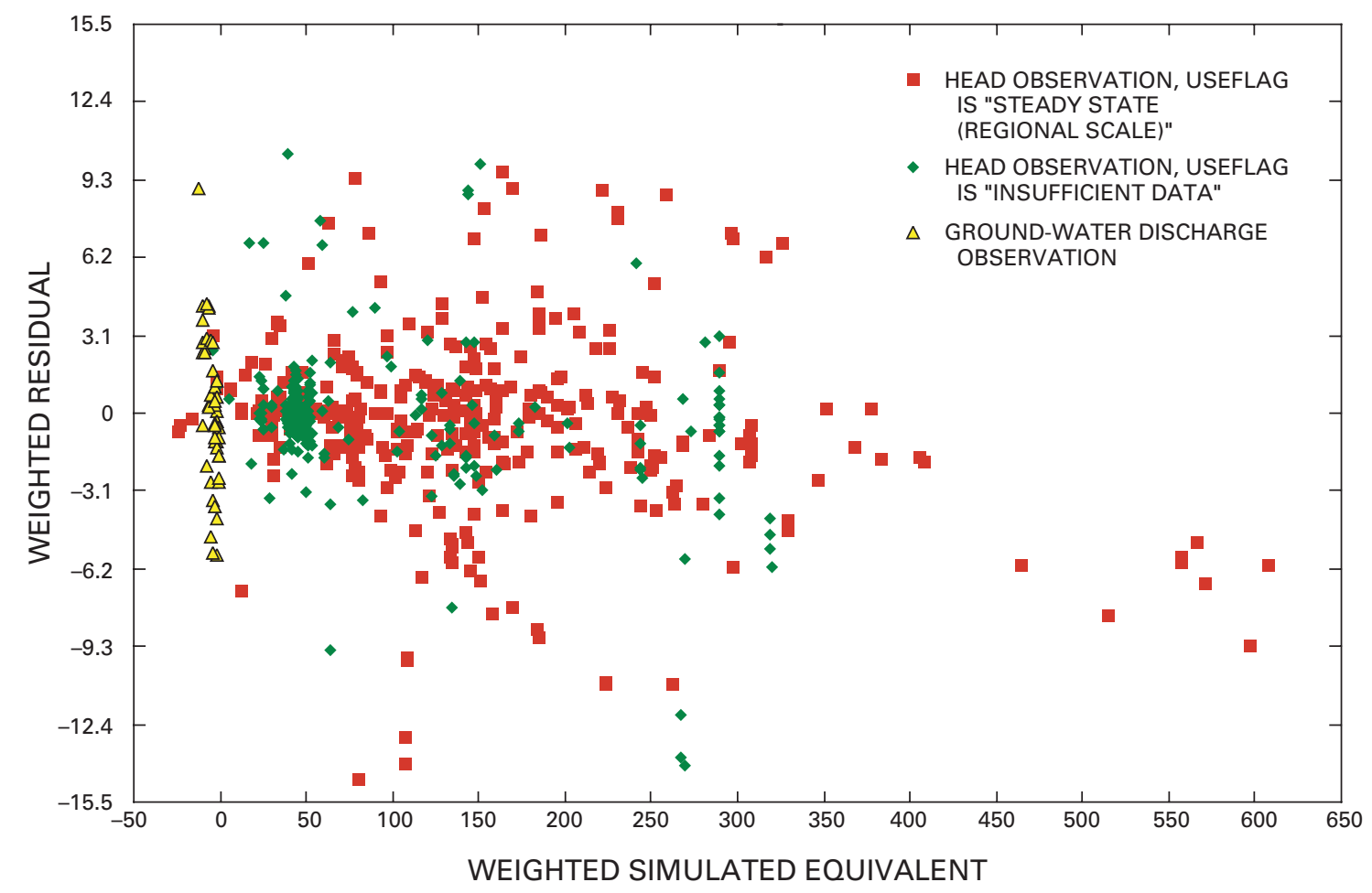

Figure 46. Weighted residuals relative to weighted simulated equivalent.

predicted heads and flows to accurately represent simulation uncertainty. In this report, confidence intervals are presented only on estimated parameter values.

The normal probability graph of the weighted residuals of the final calibrated model is shown in figure 47 . The points would be expected to fall along a straight line if the weighted residuals were both independent and normally distributed. Clearly, the points do not fall along a straight line. One possibility is that the residuals are normally distributed, but they are correlated instead of being independent. Correlations are derived from the fitting of the regression.

The source of correlation can be investigated using the graphical procedures described by Cooley and Naff (1990). Normally distributed random numbers generated to be consistent with the regression-derived correlations are called correlated normal numbers and are shown in figure 48. Most of the curvilinearity in figure 48 cannot be attributed to regression-derived correlations. This analysis suggests that the weighted residuals are not normally distributed.

Model linearity was tested using a statistic referred to as the modified Beale's measure (Cooley and Naff, 1990). The modified Beale's measure calculated for the DVRFS model equals 0.44 , which is between the critical values of 0.048 and 0.54 . If Beale's measure is less than 0.048 , the model is effectively linear. If Beale's measure is greater than 0.54, the model is highly nonlinear. Thus, the final calibrated model tends toward being nonlinear.

The lack of normality of the weighted residuals and the degree of nonlinearity of the DVRFS model indicate that linear confidence intervals may be inaccurate. It can be concluded from previous work by Christensen and Cooley (1996) that linear confidence intervals often can be used as rough indicators of simulation uncertainty, even in the presence of some model nonlinearity. The nonnormal weighted residuals indicate a greater degree of potential error in the linear confidence intervals. Despite this problem, linear confidence intervals are used in this work as rough indicators of the uncertainty in estimated parameter values. 


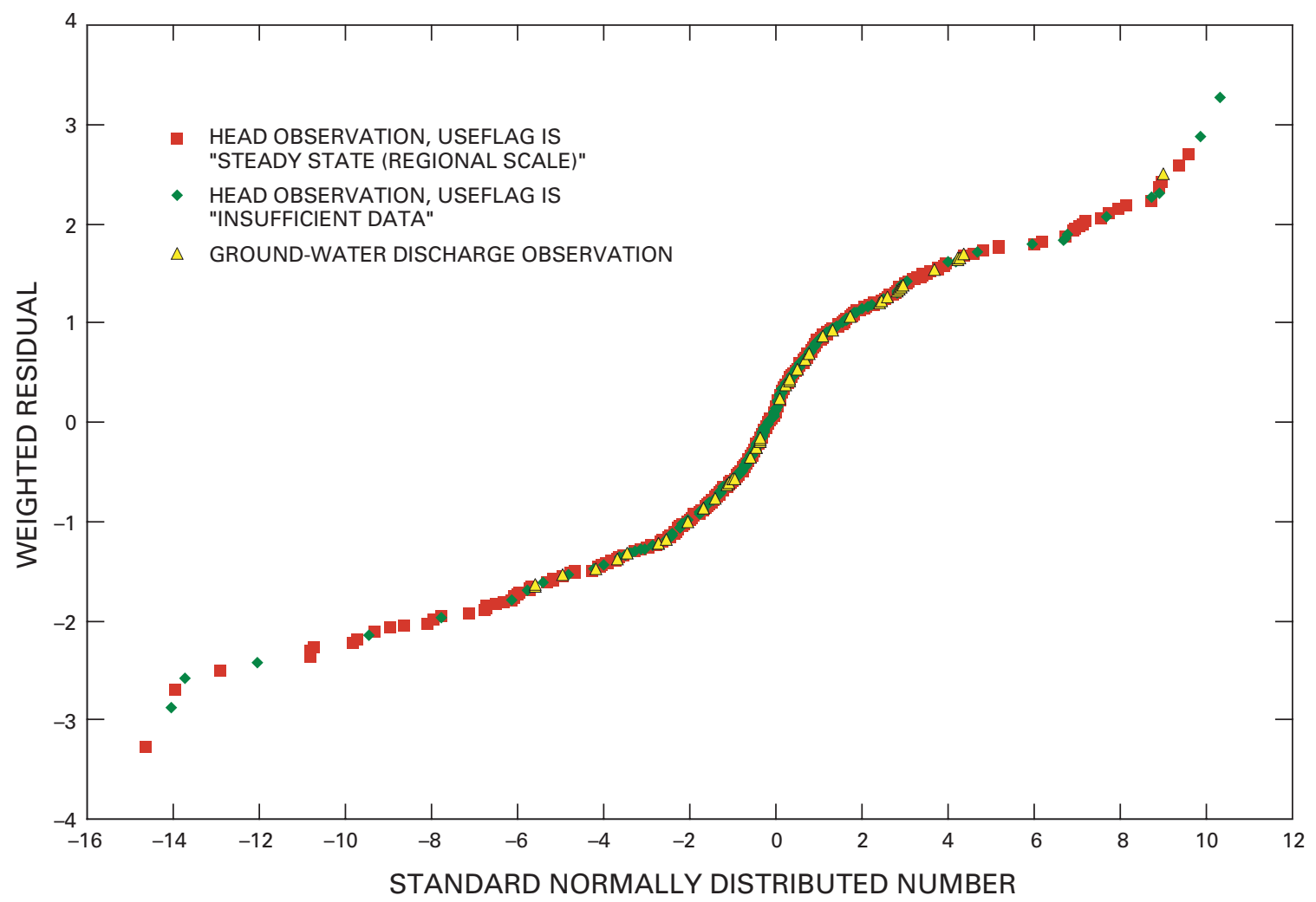

Figure 47. Normal probability plot of weighted residuals.

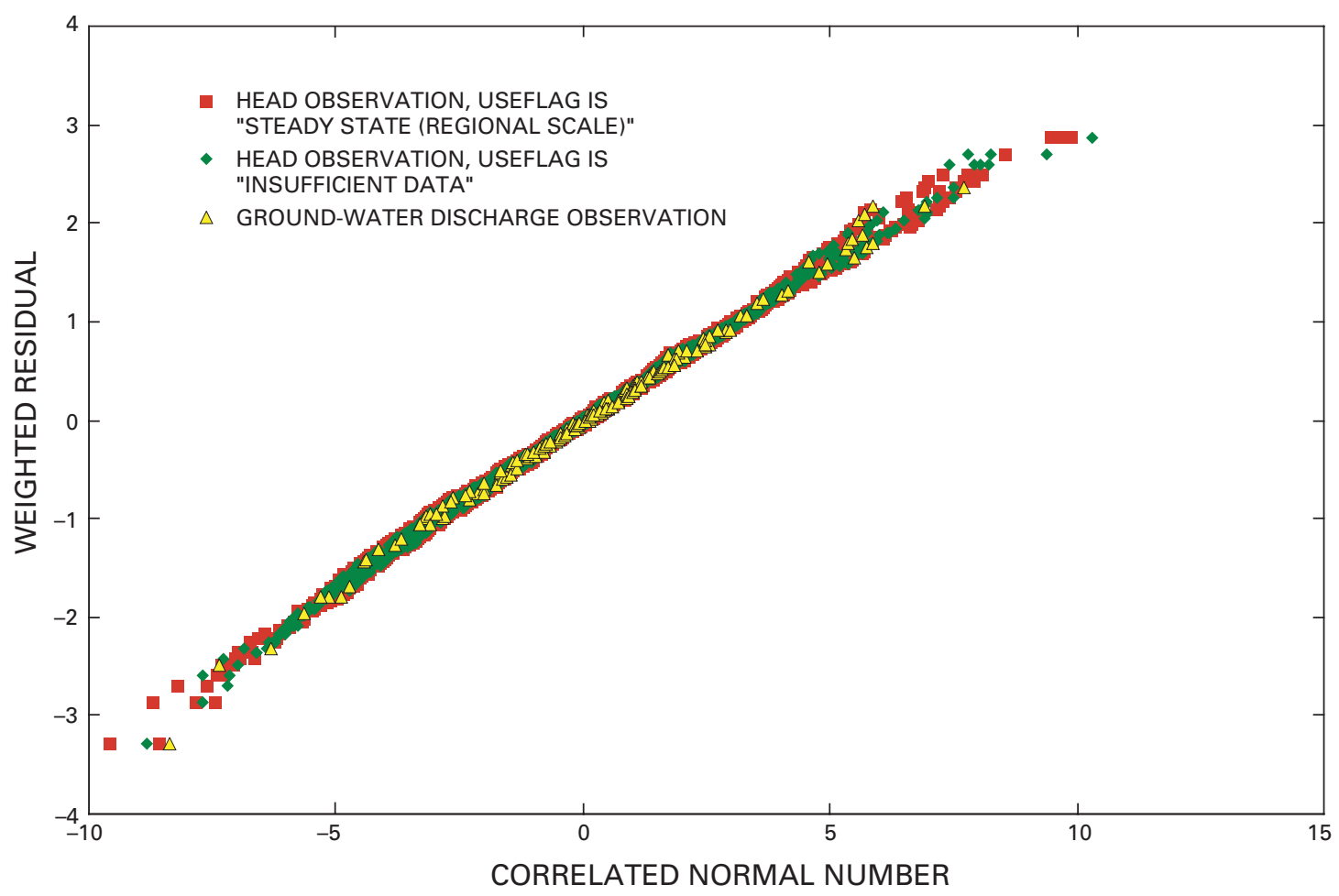

Figure 48. Normal probability plot of weighted residual against correlated normal number. 


\section{Evaluation of Estimated Parameter Values and Sensitivities}

Composite scaled sensitivities were used during calibration to decide what parameters to include and exclude from the estimation process. Parameters with relatively high CSS values often were included in the estimation process, while parameters with relatively low CSS values were not included. In some cases, a parameter may have had a high enough sensitivity to be easily estimated by the regression, but was correlated (as determined from parameter correlation coefficients) with another parameter of higher sensitivity. In these cases, the parameter of lower sensitivity typically was left unestimated. The set of parameters estimated by regression in the DVRFS model includes the 11 most sensitive parameters having less than 85 percent correlation.

These parameters are interpreted as representing the most important system characteristics, as indicated by evaluating composite scaled sensitivities. This analysis helps to ensure that the measures of prediction uncertainty calculated using the model will reflect most of the uncertainty in the system because all measures of prediction uncertainty presently available mostly propagate the uncertainty of the estimated parameter values. Uncertainty in other aspects of the model is not propagated into the uncertainty measures as thoroughly.

If a model represents a physical system adequately, and the observations used in the regression (hydraulic heads and ground-water discharges for the DVRFS model) provide substantial information about the parameters being estimated, it is reasonable to think that the parameter values that produce the best match between the observed and simulated heads and discharges would be realistic values. Thus, model error would be indicated by unreasonable estimates of parameters for which the data provide substantial information.

A measure of the amount of information provided by the observations for any parameter is the CSS value and the linear confidence interval on the parameter. Generally, a parameter with a large CSS value will have a small confidence interval relative to a parameter with a smaller CSS value. If an estimated parameter value is unreasonable and the data provide enough information that the linear 95-percent confidence interval on the parameter estimate also excludes reasonable parameter values, the problem is less likely to be lack of data or insensitivity and more likely to be model error or misinterpreted hydraulic-conductivity data.

Figures 49 through 55 show CSS values, estimated and unestimated parameter values, modelcalculated 95-percent linear confidence intervals, and 95-percent linear confidence intervals of the geometric mean gathered as part of a related study (Belcher and others, 2001). The 95-percent confidence intervals for the particular units were calculated assuming a lognormal distribution at \pm 2 standard deviations from the geometric mean (Helsel and Hirsch, 1992, p. 73-74). In most cases, the estimated parameter values and related model-calculated 95-percent linear confidence intervals are within the range of $\mathrm{K}$ values determined by Belcher and others (2001).

No prior information was included in the sumof-squares objective function to restrict the estimation process; only the model design and the observation data influenced parameter estimation. Estimation of the most important parameters without prior information has the advantage of allowing a more direct test of the model using the observation data (the hydraulic heads and ground-water discharges). In this approach, the available information on reasonable parameter values is used to evaluate the estimated parameter values. For the DVRFS model, this evaluation revealed very little indication of model error.

The confidence intervals on the parameter estimates shown in figures 49 through 55 may seem unrealistically small, but this is largely because they represent the confidence interval for the mean hydraulic-conductivity value of the defined hydrogeologic unit or zone. As pointed out by Hill (1998), confidence intervals on mean values are rapidly reduced from the entire range of the population as data are applied to the estimation of the mean. The validity of the idea that the hydrogeologic units have uniform "mean" or "effective" values is, of course, a basic hypothesis of the modeling approach used in this work. The ability of a model, developed using this approach, to reproduce the measured hydraulic heads and ground-water discharges as well as is done by the DVRFS model suggests that the approach is likely to be valid for this system.

Partly because of model nonlinearity, the CSS values change somewhat as the parameter values change. As a result, the evaluation of CSS values was repeated frequently. The final values changed somewhat but were still quite similar to initial values and 
A.

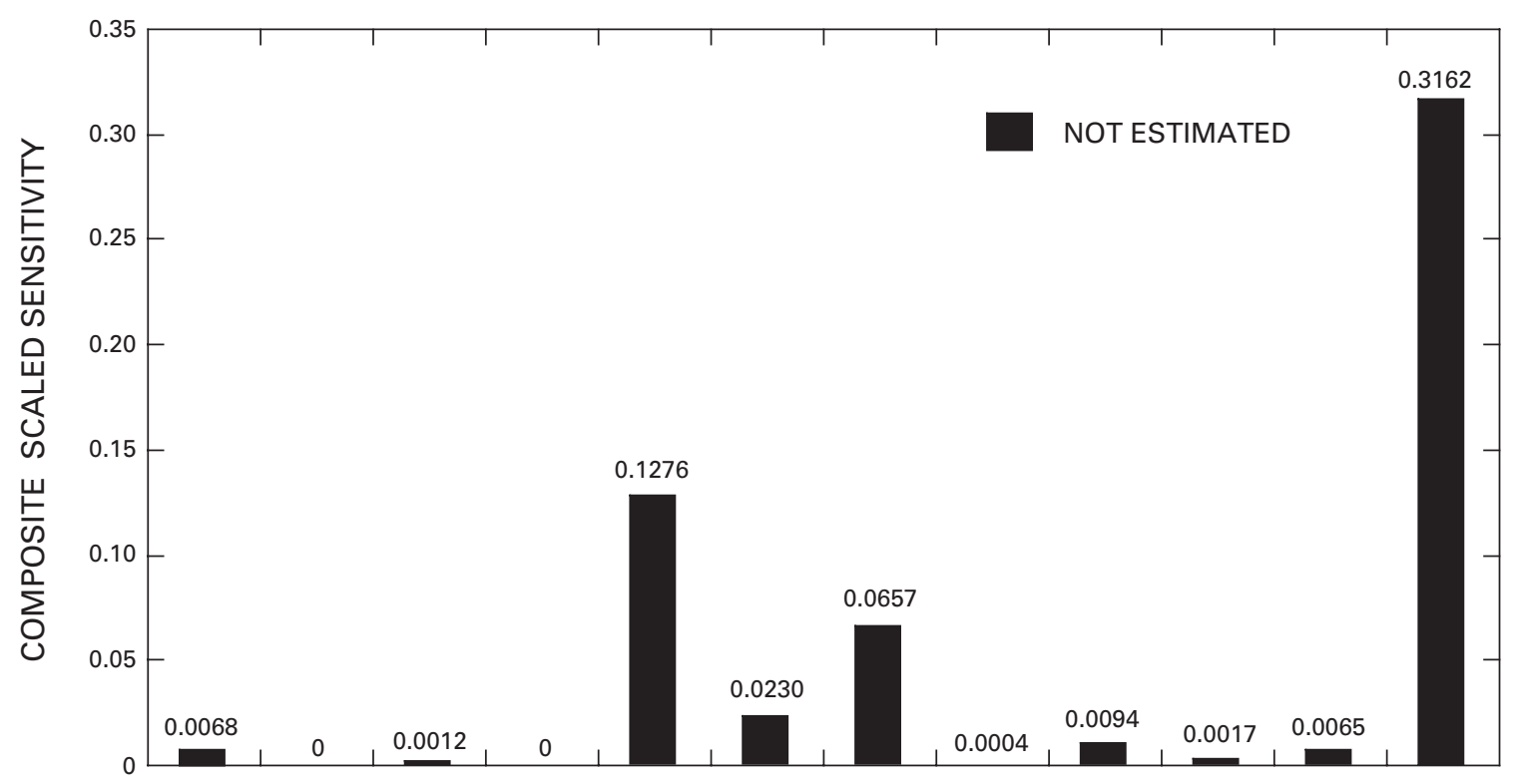

B.

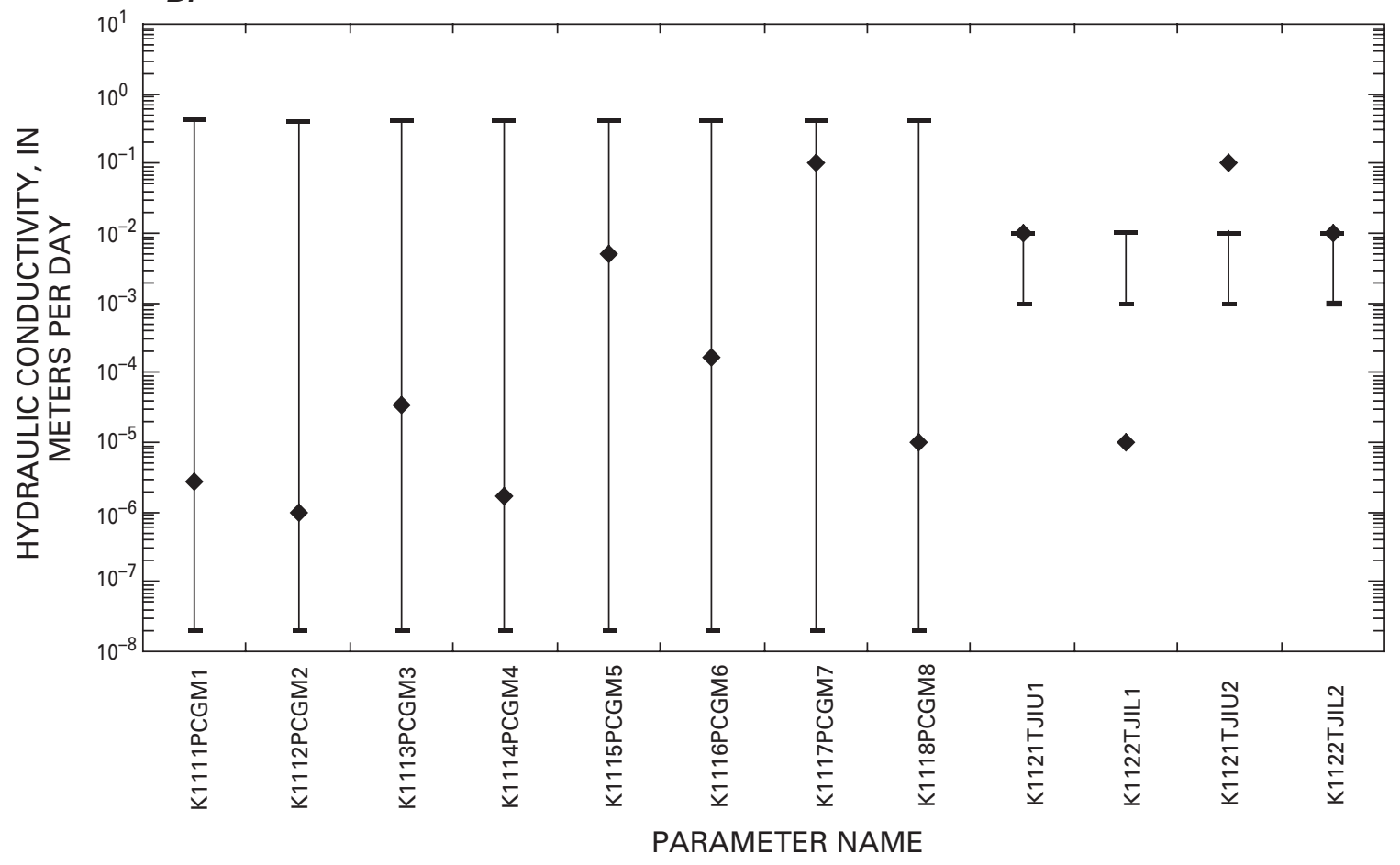

EXPLANATION

EXPECTED 95-PERCENT CONFIDENCE INTERVAL

(Belcher and others, 2001)

- HIGH

- LOW

- parameter value

Figure 49. Parameters defining hydraulic conductivity for Precambrian granites and metamorphic rocks (pCgm) and Tertiary-Jurassic intrusives (TJi): $A$, Composite scaled sensitivity; $B$, Hydraulic conductivity assigned for each parameter and expected parameter-value range. 
A.

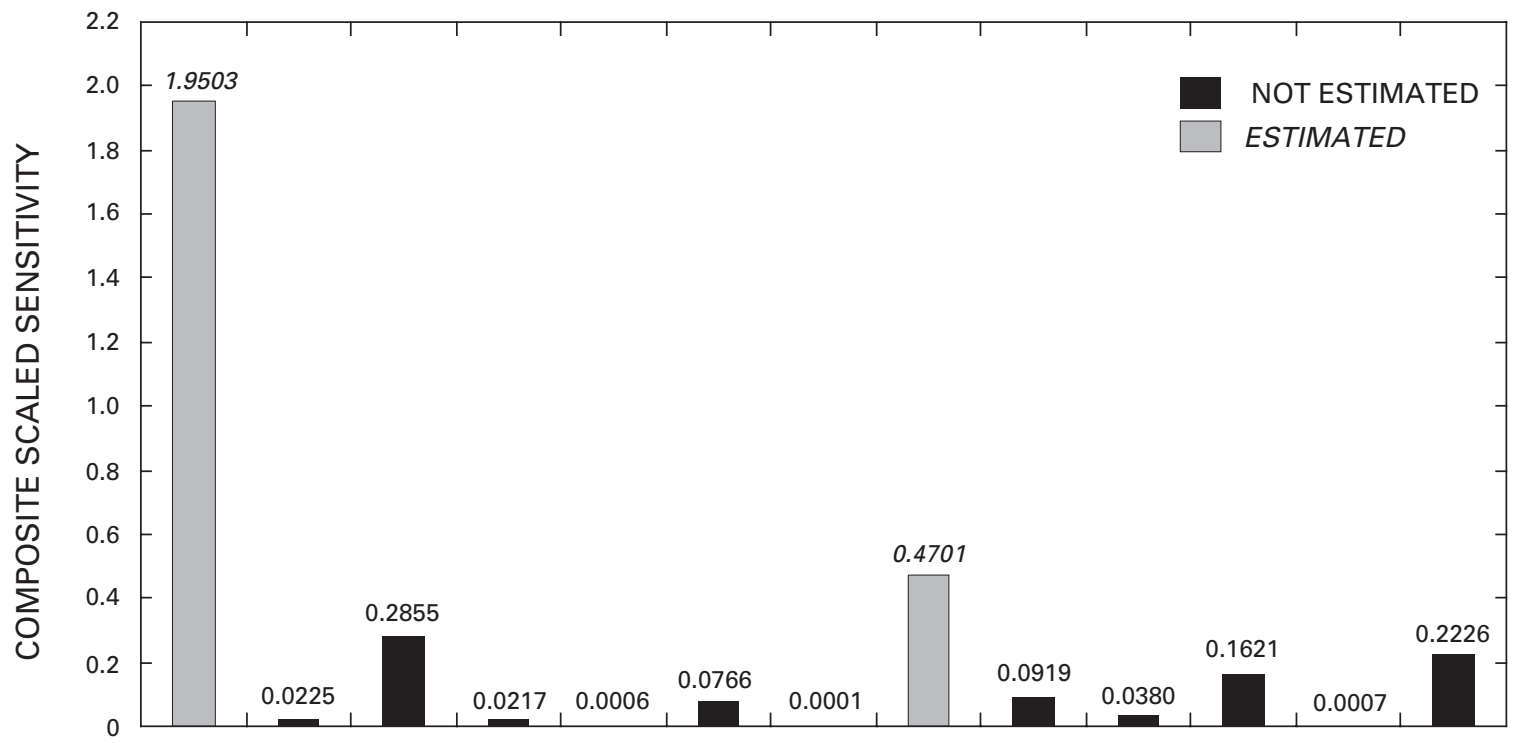

B.

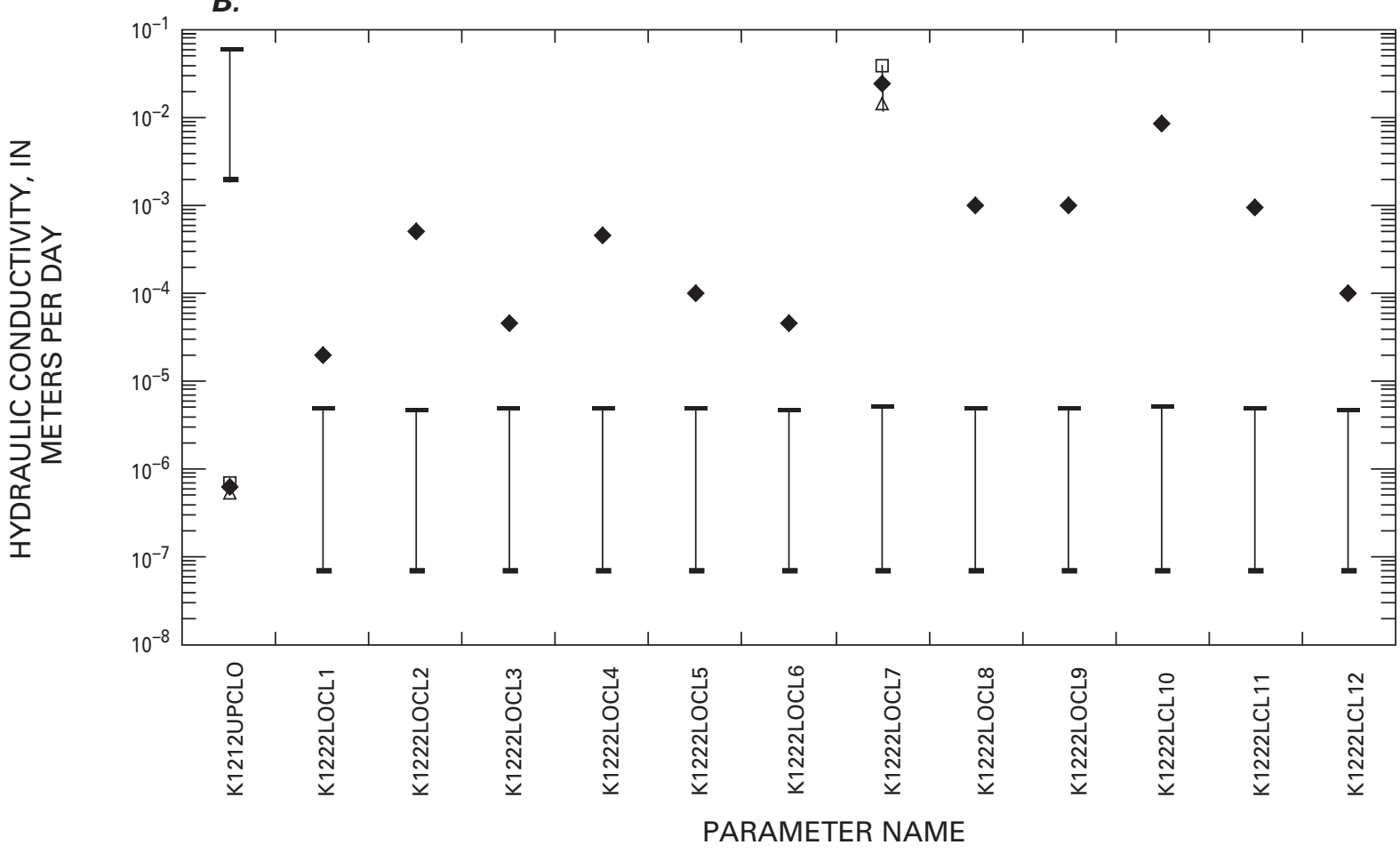

EXPLANATION

- HIGH EXPECTED 95-PERCENT CONFIDENCE INTERVAL (Belcher and others, 2001)

- LOW EXPECTED 95-PERCENT CONFIDENCE INTERVAL (Belcher and others, 2001) $\square \quad$ UPPER 95-PERCENT CONFIDENCE INTERVAL FOR ESTIMATED PARAMETERS (MODEL-CALCULATED)

$\triangle$ LOWER 95-PERCENT CONFIDENCE INTERVAL FOR ESTIMATED PARAMETERS (MODEL-CALCULATED)

- PARAMETER VALUE

Figure 50. Parameters defining hydraulic conductivity for the upper clastic confining unit (UCCU) and lower clastic confining unit (LCCU), hydrogeologic units greater than 300 meters below land surface: $A$, Composite scaled sensitivity; $B$, Hydraulic conductivity assigned or estimated for each parameter, expected parameter-value range, and linear 95-percent confidence interval for estimated parameters. 
A.
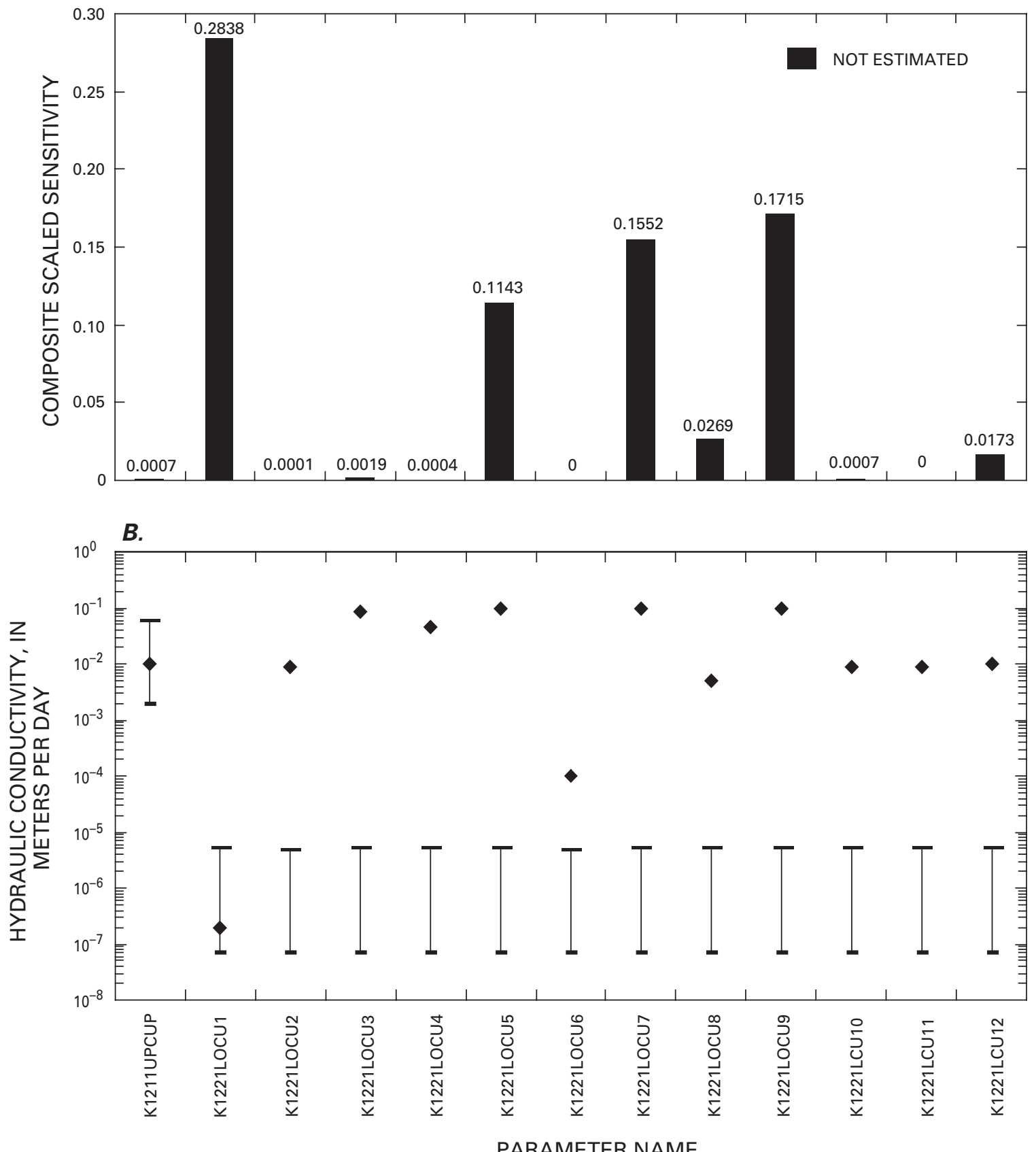

EXPLANATION

EXPECTED 95-PERCENT CONFIDENCE INTERVAL

(Belcher and others, 2001)

- HIGH

- LOW

- PARAMETER VALUE

Figure 51. Parameters defining hydraulic conductivity for the upper clastic confining unit (UCCU) and lower clastic confining unit (LCCU), hydrogeologic units less than 300 meters below land surface: $A$, Composite scaled sensitivity; $B$, Hydraulic conductivity assigned for each parameter and expected parameter-value range. 
A.

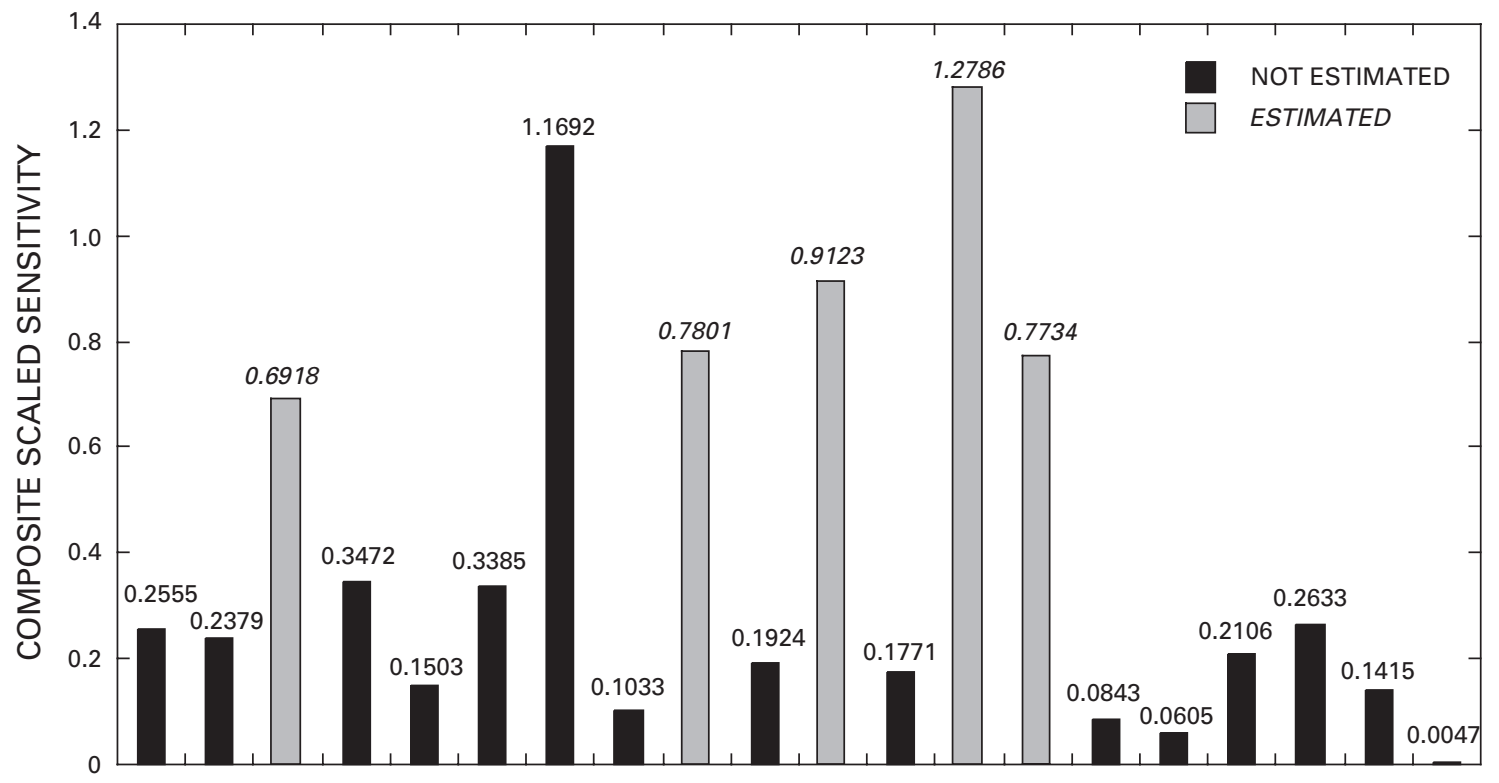

B.

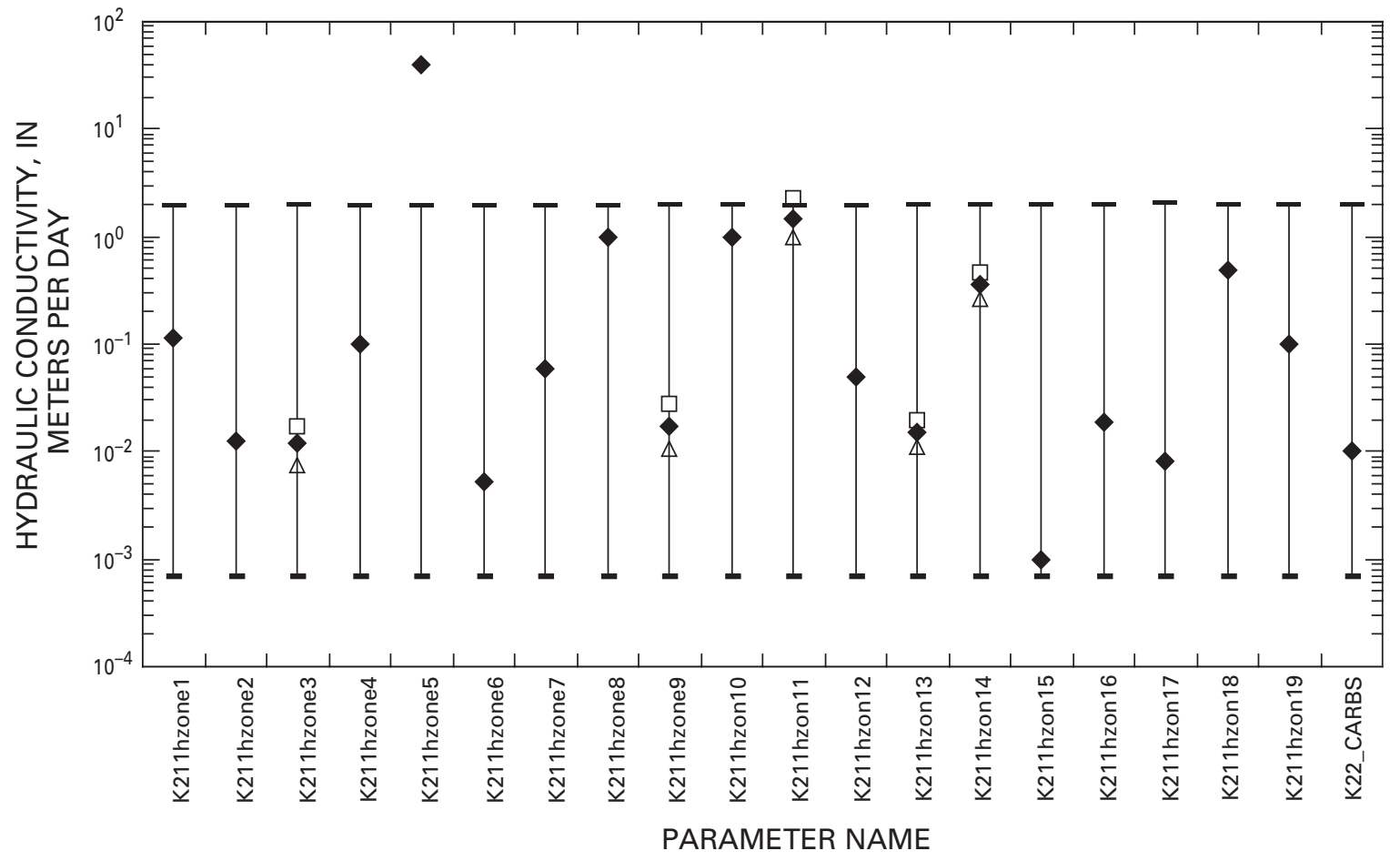

EXPLANATION
- HIGH EXPECTED 95-PERCENT CONFIDENCE INTERVAL (Belcher and others, 2001)
- LOW EXPECTED 95-PERCENT CONFIDENCE INTERVAL (Belcher and others, 2001)
$\square$ UPPER 95-PERCENT CONFIDENCE INTERVAL FOR ESTIMATED PARAMETERS (MODEL-CALCULATED)
$\triangle$ LOWER 95-PERCENT CONFIDENCE INTERVAL FOR ESTIMATED PARAMETERS (MODEL-CALCULATED)
- parameter value

Figure 52. Parameters defining hydraulic conductivity for the lower carbonate aquifer (LCA) and the upper carbonate aquifer (UCA): $A$, Composite scaled sensitivity; $B$, Hydraulic conductivity assigned or estimated for each parameter, expected parameter-value range, and linear 95-percent confidence interval for estimated parameters. 
A.
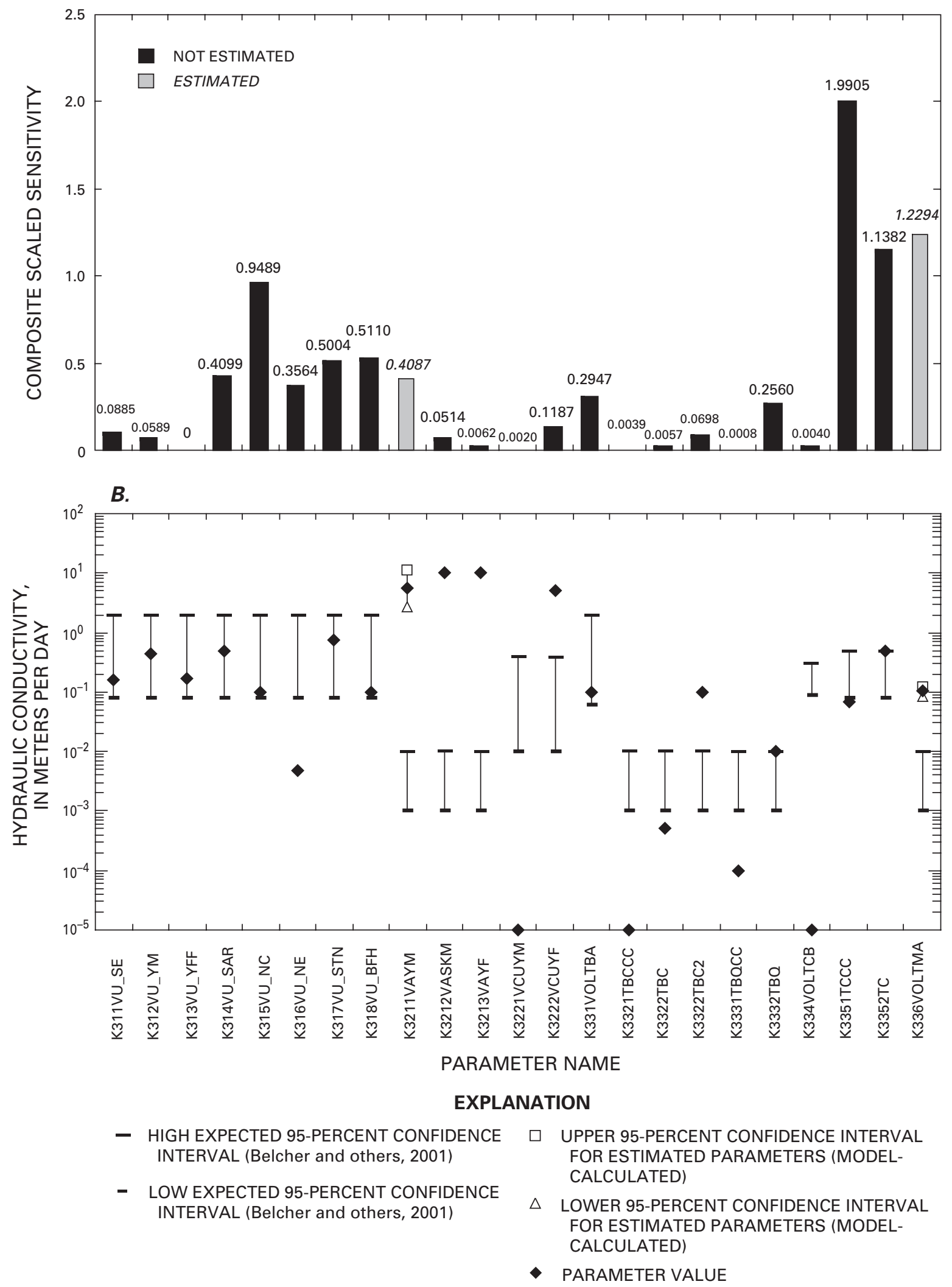

Figure 53. Parameters defining hydraulic conductivity for undifferentiated volcanic rocks (VU), volcanic aquifer (VA), volcanic confining unit (VCU), and Timber Mountain/Pahute Mesa volcanic rocks (TBA, TBCU, TBQ, TCB, TC, TMA): $A$, Composite scaled sensitivity; $B$. Hydraulic conductivity assigned or estimated for each parameter, expected parameter-value range, and linear 95-percent confidence interval for estimated parameters. 
A.
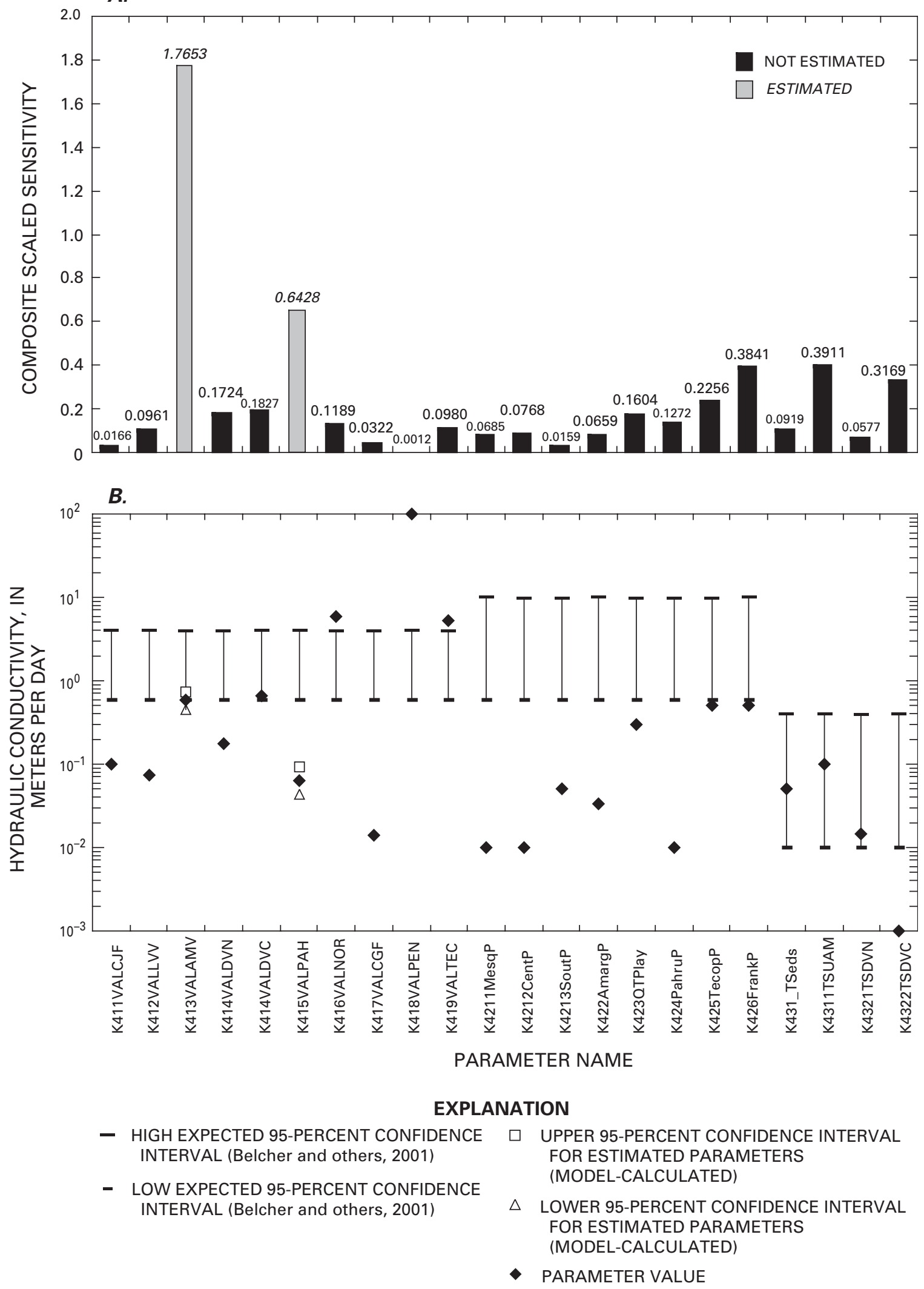

Figure 54. Parameters defining hydraulic conductivity for basin fill: Quaternary-Tertiary valley-fill alluvium (QTal), Quaternary-Tertiary playa deposits (QTp), and Tertiary sediments/Death Valley section (TSDVS): $A$, Composite scaled sensitivity; $B$, Hydraulic conductivity assigned or estimated for each parameter, expected parameter-value range, and linear 95-percent confidence interval for estimated parameters. 
A.

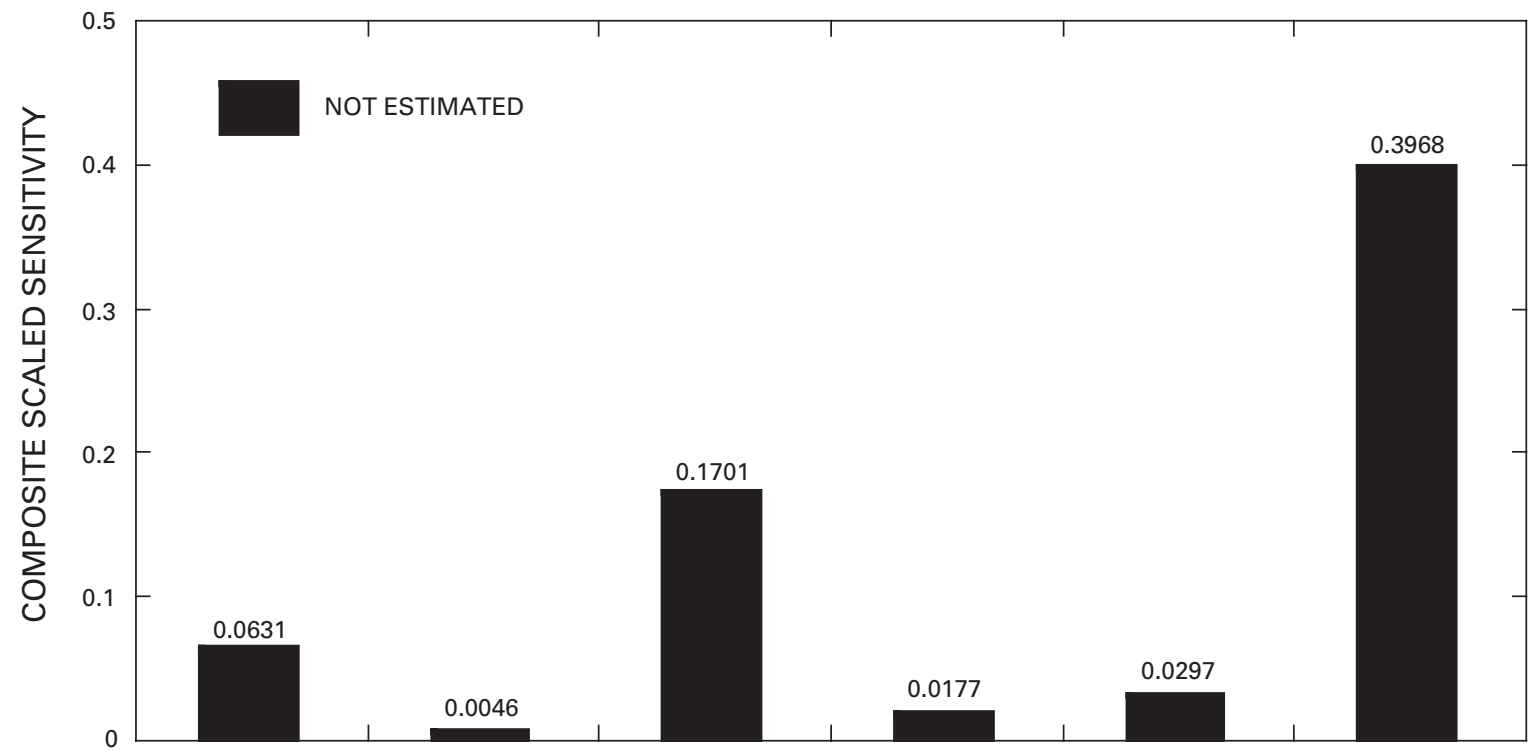

B.

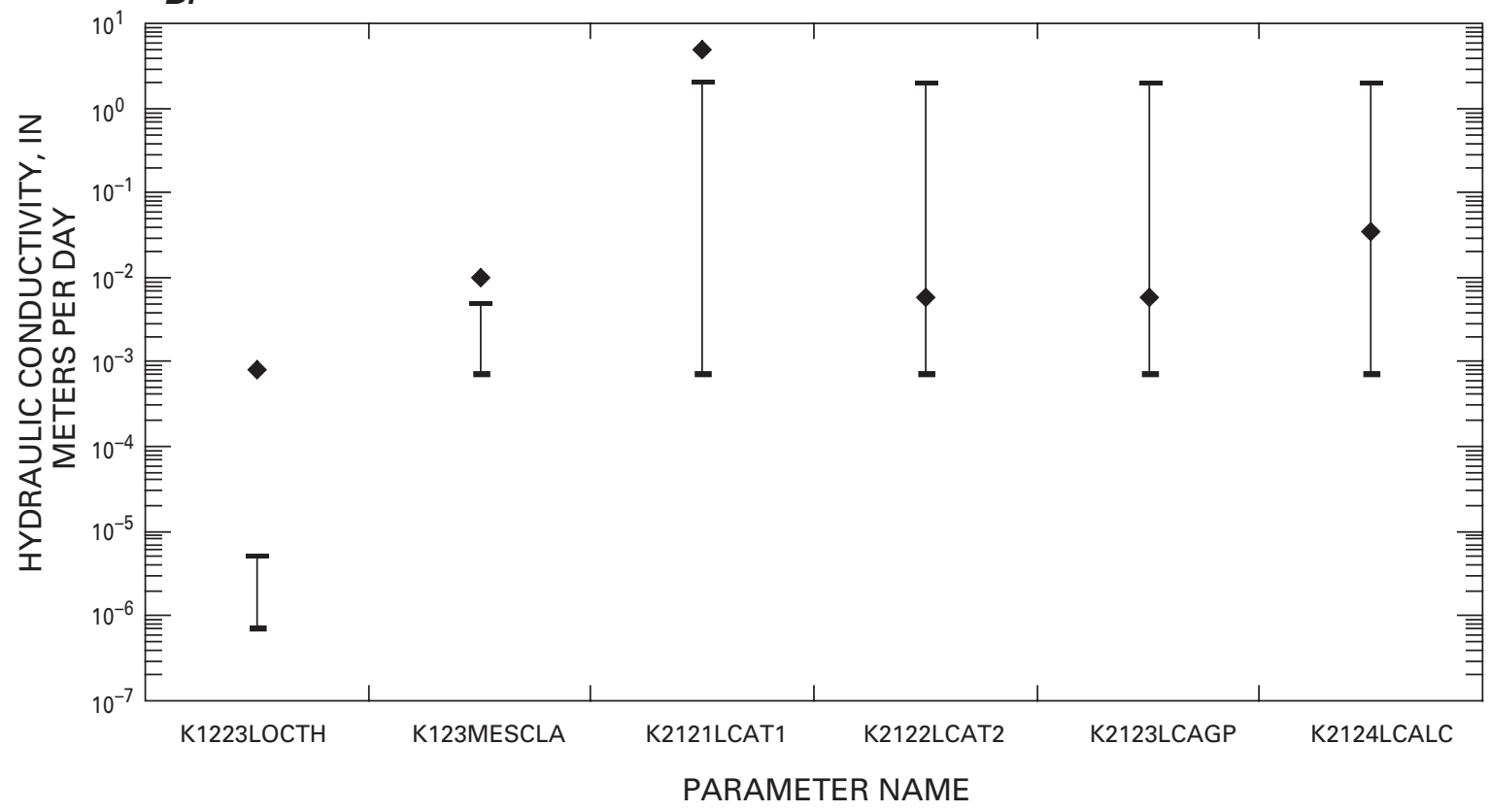

EXPLANATION

EXPECTED 95-PERCENT CONFIDENCE INTERVAL

(Belcher and others, 2001)

- HIGH

- LOW

- parameter value

Figure 55. Parameters defining hydraulic conductivity for lower clastic confining unit (LCCU) thrusts, Mesozoic volcaniclastic and sedimentary rocks (Mvs), and lower carbonate aquifer (LCA) thrusts: $A$, Composite scaled sensitivity; $B$, Hydraulic conductivity assigned for each parameter and expected parameter-value range. 
generally indicate that the parameters being estimated were the most important parameters. Exceptions occur for parameters that were correlated with parameters with larger CSS values and for parameters that mostly influence model fit to a single observation.

\section{Evaluation of Simulated Water Budgets}

The large areal extent of the DVRFS and the uncertainties associated with boundary conditions precludes a comprehensive and accurate assessment of all ground-water inflows and outflows. As a result, it is difficult to compare the simulated volumetric budget to conceptual flow-system budget estimates. A discussion of the simulated water budget, however, is still warranted.

A water budget for the Death Valley regional ground-water flow system that is based on simulated and estimated values for various inflow and outflow components is presented in table 30 . The results are important because they indicate that despite significant strides in reducing the likely uncertainty in flux out of the flow system at various ground-water discharge points within the flow system, the high uncertainty in recharge makes it difficult to determine what part of the model has the most error with regard to flux. Significant uncertainties still exist with regard to recharge and flow-system boundary conditions.

\section{Summary of Model Evaluation}

The results presented in this section suggest that the DVRFS model reproduces the measured hydraulic heads and estimated water-budget components reasonably accurately, but with noted levels of uncertainty. In addition, the estimated parameter values are reasonable.

Because the weighted residuals are not entirely random, some model error may be indicated. This is mostly related to the occurrence of (1) large positive weighted residuals for some hydraulic-head observations located dominantly in large hydraulic gradient areas, (2) large weighted residuals for ground-water discharges at Ash Meadows, and (3) large, positive weighted residuals for ground-water discharges at Oasis Valley. In addition, weighted residuals are not normally distributed. These results, combined with the previously discussed observation that every model update considered thus far significantly improved the model fit, suggests that additional calibration and reduction in conceptual model uncertainty may significantly improve model accuracy. This analysis suggests that the DVRFS model is a reasonable representation of the physical system, but evidence of model error exists.

\section{MODEL LIMITATIONS AND POTENTIAL FUTURE IMPROVEMENTS}

Despite the model error and the above-described inadequacies, the DVRFS model contains the most upto-date representation of hydrogeologic data for the Death Valley region. The inherent limitations result from uncertainty in three basic aspects of the model, including inadequacies in (1) hydraulic-head and ground-water discharge observations, (2) representation of geologic complexity in the hydrogeologic framework model, and (3) representation of the ground-water system in the flow model. These limitations are discussed below and means for improvement are offered.

\section{Observation Limitations}

Hydraulic-head and ground-water discharge observations constrain model calibration through the parameter estimation process; therefore, uncertainty in these observations results in uncertainty in flow model results. Although head observations were thoroughly analyzed prior to and throughout the calibration process, there was still uncertainty regarding (1) the quality of the observation data, (2) appropriateness of the hydrogeologic interpretations, and (3) the way in which the observation is represented in the flow model.

\section{Quality of Observations}

The sparse distribution and high concentration, or clustering, of hydraulic-head observations limit the flow model because it results in the overemphasis of many observations in isolated areas, thus biasing those parts of the model. Outside the Yucca Mountain, NTS, Amargosa Farms, and Pahrump Valley areas waterlevel data are sparse, both spatially and temporally. High clustering of observations is noted in some areas of the Amargosa Desert, Yucca Mountain, Pahute Mesa, Yucca Flat, and Pahrump. A method of better 
distributing weights for these situations needs to be imposed.

Some hydraulic-head observations used to constrain the model are affected by pumping and, thus, introduce bias. Many of the observations in agricultural areas are, in fact, pumping wells. Because many of the wells in the Amargosa and Pahrump Valleys were drilled at the start of, or after, ground-water development, it is difficult to determine which, if any, of these observations likely represent predevelopment conditions. A transient simulation of the flow system would better represent ground-water conditions in these areas.

\section{Interpretation of Observations}

It is difficult to determine whether head observations represent regional or perched conditions. Field testing is often not sufficient to conclusively distinguish between regional and perched conditions. The data necessary to unequivocally determine the presence of perched water are rarely, if ever, available. Because large simulated hydraulic-head residuals in recharge areas often suggest the possibility of perched water, the hydraulic-head observation is either removed or the observation weight decreased. Fewer observations, or observations with lower weights, result in higher model uncertainty. Further evaluation of potentially perched ground-water levels in many parts of the model domain would be required to reduce this uncertainty.

Large hydraulic gradient areas also are difficult to interpret, and the lack of water levels to clearly define these features only exacerbates the situation. Hydraulic-head observations defining large hydraulic gradients also typically are associated with perched or localized water. Removing these uncertainties would require additional field work and well testing.

Accurate ground-water discharge estimates for evapotranspiration areas have not been available in the DVRFS until very recently. In fact, spatially distributed ground-water discharge observations for the region are only available beginning in 1995 (Laczniak and others, 1996). Prior to 1995, Malmberg (1967) was the only investigator to show the spatial distribution of ET by phreatophytes in Pahrump Valley. The map developed by Malmberg depicted phreatophyte occurrence and corresponding ET for water years 1959 through 1961. This lack of data limits how well these discharge areas and related areas can be simulated because the predevelopment steady-state assumption suggests that these rates accurately describe groundwater discharge at that time. Clearly this is not the case because modern-day phreatophyte zones that are used to estimate ET rates have been impacted by pumping. These data deficiencies are not recoverable and the related uncertainty will be present in any steady-state model of the flow system. A transient model may be better suited to utilize these data because the observations may be used at an appropriately corresponding time step.

\section{Representation of Observations}

Simulating small discharge volumes $\left(<700 \mathrm{~m}^{3} / \mathrm{d}\right)$ was difficult in the DVRFS model. This limitation may be resolved either by creating a higher resolution model with smaller grid cells or by removing the small-volume observations from the model.

The elevation assigned to defined drains in the DVRFS model also affected the model's ability to accurately simulate ground-water conditions. The elevation of drains in ET areas was set to the lowest corresponding land-surface elevation based on a 1:24,000-scale digital elevation model. This method may not accurately approximate the extinction depth for all discharge areas, particularly in areas with highly variable root depth and discontinuous areas of capillary fringe. Penoyer Valley is an example of a discharge area that may have a zone of fairly extensive capillary fringe. Observed hydraulic heads occurring in flow model cells with drains are lower than the drain elevation, which is set to land surface. The result is that water will not discharge at the Penoyer Valley drain if the hydraulic heads are simulated accurately.

Incised drainages and other focused discharge areas are difficult to accurately simulate at a grid resolution of $1,500 \mathrm{~m}$. In many cases, the hydraulic conductivity of the hydrogeologic units present at the land surface regulates the simulated discharge. In situations where this construct does not regulate flow, a consistent method for using drain conductance needs to be employed.

An alternative method of representing groundwater discharge using the ET or Stream Packages of MODFLOW-2000 may reduce these model representation inadequacies. 


\section{Hydrogeologic Framework Limitations}

Accurate simulation of many of the important flow-system characteristics depends on an accurate understanding and representation of the hydrogeologic conceptual model. Limitations exist in the groundwater flow model because of the difficulties inherent in the interpretation and representation of the complex geometry and spatial variability of hydrogeologic materials and structures in a hydrogeologic framework and ground-water flow model.

\section{Complex Geometry}

Geometric complexity of hydrogeologic materials and structures are apparent throughout the model domain. One notable example is the Las Vegas Valley shear zone. Simulation of hydraulic heads in the area are limited by the current understanding of faultsystem geometry and the appropriateness of the representation in the hydrogeologic framework and groundwater flow model.

Similarly, the large hydraulic gradient that extends from the Groom Range through the Belted and Eleana Ranges to Yucca Mountain and the Bullfrog Hills is inadequately simulated because of limitations in hydrogeologic data that define the complex geometries that cause the feature; however, the feature is also inadequately simulated because of simplifications inherent in HFM and ground-water flow model construction and discretization.

\section{Complex Spatial Variability}

As with complex hydrogeologic geometries, spatial variability of material properties of the hydrogeologic units and structures also is underrepresented in the DVRFS model as a result of data limitations and simplifications resulting from HFM and flow-model construction and discretization. The assumption of homogeneity within a given hydrogeologic unit in the HFM or K-zone in the ground-water flow model limits the simulation by removing the potential effects of variability in grain-size distribution, degree of welding, and fracture density and orientation. A particularly important area where this impacts the simulation is in the vicinity of Oasis Valley and the Bullfrog Hills where the observed effects of hydrothermal alteration are incompletely characterized by data and inadequately represented in the HFM and ground-water flow model. In fact, many of the inade- quacies of the simulation within the SWNVF are in part due to the underrepresentation of local-scale hydrogeologic complexities in the regional-scale HFM and ground-water flow models.

\section{Flow Model Limitations}

Two basic limitations of the DVRFS model are inherent in construction of the numerical flow model. These are (1) representation of the physical framework, and (2) representation of the hydrologic conditions.

\section{Physical Framework Representation}

Discretization and abstraction of the physical hydrogeologic framework impose limitations on all components of the HFM and numerical ground-water flow. While the 1,500-m resolution is appropriate to represent regional-scale conditions, higher resolution would improve simulation accuracy particularly in areas of geologic complexity. The larger grid cells tend to generalize important local-scale complexities that have an impact on regional hydrologic conditions. This situation is particularly prevalent in large hydraulic gradient areas where sharp geologic contacts or local-scale fault characteristics can influence regional hydraulic heads and ground-water discharges. Ultimately, smaller grid cells will be required or more local-scale models constructed for critical areas in the DVRFS.

\section{Hydrologic Conditions Representation}

The hydrologic conditions that, perhaps, most influence the DVRFS simulation are the representation of external and internal boundary conditions.

Limitations in external boundary-condition definition are the result of both incomplete understanding of natural conditions and poor representation of the natural conditions in the numerical flow model. Because very little data exist in the areas defined as lateral flow-system boundaries, the boundaries are highly uncertain. Also, defining these boundaries in a steady-state flow model is effectively limited to either a no-flow or a constant-head boundary. Both types of boundary definitions impose significant constraints on model results. Reducing these limitations through improved characterization of system boundaries in the 
field or definition of the boundaries in the flow model would reduce model uncertainty.

Perhaps the most significant limitation in internal boundary conditions exists in the representation of ground-water recharge. The limitation is threefold, including (1) inaccurate estimation of net infiltration due to data-input limitations to the net infiltration model, (2) the assumption that net infiltration results in net regional recharge, and (3) the apparently small $\mathrm{K}$ of hydrogeologic units at the water table limits the amount of recharge that can enter the regional flow system.

As described above, the INFIL model developed for this study clearly overestimates net infiltration in many parts of the flow-model domain. The limitations of the net infiltration model may be resolved by improving the data inputs associated with root depth in bedrock areas, bedrock permeability, soil moisture properties, and precipitation distribution.

Using net infiltration as the numerical flowmodel input for recharge assumes that all infiltrating water that passes the root zone ultimately crosses the water table. This assumption ignores the possibility that infiltrating water could be intercepted and diverted by a zone of lower permeability in the unsaturated zone. It also ignores the possibility of deep evaporation of water in the unsaturated zone. Despite the attempt of the authors to minimize this limitation, the current results still require improvement. This limitation may be resolved by developing a means to account for deep, unsaturated-zone processes that may reduce or redistribute infiltrating water.

\section{SUMMARY}

In the early 1990's, two numerical models of the Death Valley regional ground-water flow system were developed by DOE. In general, the two models are based upon the same basic hydrogeologic data set. In 1998, the DOE requested that the USGS develop and maintain a ground-water flow model of the Death Valley regional ground-water flow system in support of DOE programs at the Nevada Test Site. The purpose of developing this "second-generation" regional model was to enhance the knowledge and understanding of the Death Valley regional ground-water flow system as new information and tools are developed. The USGS also was encouraged by DOE to cooperate to the fullest extent with other Federal, State and local enti- ties in the region to take advantage of the benefits of their knowledge and expertise.

The short-term objective of the DVRFS project was to develop a steady-state representation of the predevelopment conditions of the ground-water flow system utilizing the two geologic interpretations used to develop the previous numerical models. The longterm objective of the DVRFS project was to construct and calibrate a transient model that simulates the ground-water conditions of the study area over the historical record utilizing a newly interpreted hydrogeologic conceptual model. This report describes the result of the predevelopment steady-state model construction and calibration.

The DVRFS is situated within the southern Great Basin, a subprovince of the Basin and Range physiographic province and encompasses approximately $100,000 \mathrm{~km}^{2}$ bounded by lat. $35^{\circ} \mathrm{N}$. and $38^{\circ} 15^{\prime} \mathrm{N}$. and by long. $115^{\circ} \mathrm{W}$. and $118^{\circ} \mathrm{W}$. The arid landscape is dominated by isolated mountain ranges rising abruptly from broad, alluvium-filled desert basins. Altitudes range from $86 \mathrm{~m}$ below sea level in Death Valley to 3,600 m above sea level in the Spring Mountains. Altitude differences between valleys and adjoining mountains exceed 1,500 m; such abrupt changes may cause relatively large gradients in the potentiometric surface.

Climatic conditions in the DVRFS are controlled by both altitude and latitude. The northern part of the region forms part of the Great Basin Desert, which is characterized by warm, dry summers and cold, dry winters. The southern part of the region forms part of the Mojave Desert, which is characterized by hot, dry summers and warm, dry winters. The central region around the NTS has been called the Transition Desert, which represents a mixing of the two climates. Precipitation in the region is influenced by two distinct storm patterns affecting the desert climate-one in the winter, the other in summer. Winter precipitation (dominantly snow) tends to be of low intensity and long duration and covers large areas. In contrast, most summer rains result from localized convective thunderstorms of high intensity and short duration.

The soils and vegetation of the Death Valley region are controlled to a significant degree by climatic, geomorphic, and hydrologic factors. These relations are highly variable and complex. Soils in the DVRFS typically follow a pattern of lithosols on the mountains, medium- to coarse-textured soils on allu- 
vial fans and terraces, and fine-grained, alluvial soils in the valley floors. In general, the soils of the mountains and hills are shallow and exhibit a coarse texture with little moisture-holding capacity. Vegetation distributions in the region are influenced by many factors. Water availability and temperature exhibit latitudinal and altitudinal controls that are dominantly climate related. Thus, vegetation communities in the region demonstrate both topographic and geographic patterns. Mixing of the cold, northern Great Basin Desert climate with the warm, southern Mojave Desert climate results in a heterogeneous distribution of plant associations rather than distinct homogeneous associations.

The DVRFS has a long and active geologic history, including intermittent marine and nonmarine sedimentation, large-scale compressive deformation, plutonism, volcanism, and extensional tectonics. Consequently, diverse rock types, ages, and deformational structures are often juxtaposed to each other. As a result, subsurface conditions are variable and complex. Knowledge of the geologic diversity beneath the alluvial basins is indirect in most of the region.

The DVRFS consists of Proterozoic- and Cambrian-aged clastic and crystalline rocks; Paleozoic-aged clastic and carbonate rocks; clastic and intrusive rocks of Mesozoic age; varied fluvial, paludal, and playa sedimentary deposits of Pliocene age; volcanic rocks and alluvium; and Tertiary alluvium and colluvium and eolian deposits of Quaternary age. The region has been altered by several major structural events. Structural and tectonic features of the study area reveal a long, complex tectonic evolution.

Ground-water flow in the DVRFS generally can be described as dominated by interbasinal flow and may be conceptualized as having two main components: a series of relatively shallow and localized flow paths that are superimposed on deeper, regional flow paths. A significant component of the regional groundwater flow is through a thick Paleozoic carbonate rock sequence. Throughout the regional flow system, ground-water flow is probably controlled by extensive and prevalent structural features that result from regional faulting and fracturing.

The conceptual model of the DVRFS used for this study is adapted from the two previous groundwater modeling studies. A description of flow-system characteristics includes a discussion of system boundaries, hydrogeologic framework and structures, and the source, occurrence, and movement of ground water. Estimates of ground-water system influx through natural infiltration and discharge by evapotranspiration also were updated for this investigation.

The upper boundary surface of the Death Valley ground-water flow system is the water table. Under natural, or predevelopment, conditions, ground water moves into the flow system across this boundary as regional ground-water recharge or out of the system across this boundary at natural ground-water discharge sites, such as springs and wet playas. The lower surface is an arbitrary depth where ground-water flow is dominantly horizontal and moves with such small velocities that the volumes of water involved do not significantly affect regional flow estimates. The lateral boundaries of the ground-water flow system may be either no-flow or flow boundaries. No-flow conditions exist where ground-water movement across the boundary is prevented by physical barriers or divergence of ground-water flow paths resulting in a ground-water divide. Lateral flow boundaries exist where ground-water potentiometric gradients permit flow across a boundary through fractures or higher permeability zones. Lateral flow boundaries (underflow) include sections of the delineated boundary where ground water is interpreted to flow into the system at Mud Lake and Salt Creek or out of the system at Pahranagat Lakes.

The 3D digital hydrogeologic framework model developed for the DVRFS contains elements of both of the HFMS used in the previous investigations. The hydrogeologic framework defines the physical geometry and composition of the surface and subsurface materials through which ground water flows. The HFM defines the fundamental nature of the groundwater flow system and includes a definition both of the hydrogeologic units and the hydrogeologic structures in the basin.

The major hydrogeologic units from oldest to youngest are: the lower clastic confining unit (LCCU), the lower carbonate aquifer (LCA), the upper clastic (Eleana) confining unit (UCCU), the upper carbonate aquifer (UCA), the volcanic aquifers (VA) and volcanic confining units (VCU), and the alluvial aquifer (QTal). The LCCU forms the basement and is generally present beneath the other units except in caldera complexes. The LCA is the most extensive and transmissive unit in the region. It is present in most of the area, although it does not control ground-water flow within the caldera complexes. The UCCU is 
present in the north-central part of the NTS. It typically impedes flow between the overlying UCA and underlying LCA, and is associated with many of the large hydraulic gradients in and around the NTS. The VA and VCU form a stacked series of alternating aquifers and confining units in and around the SWNVF. The VA are moderately transmissive and are saturated in the western sections of the NTS. Because of the volume of ground water withdrawn from the QTal, it forms a discontinuous, albeit important, aquifer in the region.

Hydrogeologic structures likewise influence ground-water flow. Faults in the Death Valley region may affect ground-water flow by acting as relative barriers, conduits, and combined conduit/barriers, or by offsetting strata of different hydrologic characteristics. A subset of the mapped faults in the DVRFS was chosen to be incorporated as relative barriers in the flow model. These faults were chosen based on their orientation and length. Faults longer than $5 \mathrm{~km}$ and generally perpendicular to the ground-water flow direction were selected to be incorporated as relative barriers.

As dictated by project scope, very little reinterpretation and refinement were made where these two framework models disagree; therefore, limitations in the hydrogeologic representation of the flow system exist. Despite limitations, the HFM provides the best representation to date of the hydrogeologic units and structures that control regional ground-water flow and serves as an important information source used to construct and calibrate the predevelopment steadystate flow model.

This study includes a detailed description of the source, occurrence, and movement of ground water in the DVRFS which is adapted from D'Agnese and others (1997, p. 62-69) to incorporate elements of the UGTA regional model study (U.S. Department of Energy, 1997). The ground-water flow in the DVRFS is most easily described in terms of three major subregional flow systems. These subdivisions are for descriptive purposes only and do not define discrete, independent flow systems. Each subregion name reflects the part of Death Valley into which it discharges. Because the Central Death Valley subregion is so large, it is divided into three ground-water basins. The subregions, or the ground-water basins, are further divided into sections. Flow in each section is defined by an interpreted dominant flow path.
A complex array of mechanisms accounts for flow into, through, and out of the regional groundwater flow system. Natural discharges from the regional ground-water flow system occur by ET and springs. In this study, ET rates were adapted from a related investigation that developed maps of ET areas and computed rates from micrometeorological data collected within the local area over a multiyear period. In some cases, historical spring flow records were used to derive ground-water discharge rates for isolated regional springs.

For this investigation, a process-based, numerical model was developed to estimate net infiltration. This result can be used to represent recharge by assuming that water that infiltrates past the "root zone" ultimately becomes ground-water recharge. Estimates of net infiltration based on this water-balance approach, however, suggests that recharge in the DVRFS exceeds the estimated ground-water discharge for the basin by almost a factor of four. The net infiltration model contains some assumptions and limitations with regard to soil moisture, soil thickness, ET rates, bedrock permeability, and precipitation distributions that may result in these higher than expected values. Despite this limitation, the net infiltration model does provide a good starting point for estimating regional ground-water recharge in the groundwater flow model.

The DVRFS was simulated using a 3D steadystate model that incorporated a nonlinear least-squares regression technique to estimate aquifer parameters. The numerical modeling program MODFLOW-2000 was used to construct a finite-difference model consisting of 194 rows, 160 columns, and 15 layers. The grid cells were oriented north-south and were of uniform size, with side dimensions of 1,500 $\mathrm{m}$. The model grid encompasses about $70,000 \mathrm{~km}^{2}$ and the layers span thicknesses of 50 to $300 \mathrm{~m}$.

The required model-parameter values were supplied by discretization of the 3D HFM and digital representations of the remaining conceptual model components. The 3D simulation and corresponding sensitivity analysis supported the hypothesis of interactions between a relatively shallow local and subregional flow system and a deeper, dominant regional system controlled by the carbonate aquifer.

During calibration of the model, techniques available in MODFLOW-2000 allowed for estimation of a series of parameters that provided a best fit to observed hydraulic heads and outflows. Numerous 
conceptual models were evaluated to test the validity of various interpretations about the flow system. Conceptual model evaluations focused on testing hypotheses concerning (1) the location and type of flow-system boundaries, (2) the definition of recharge areas, and (3) variations in interpretation of the hydrogeologic framework. For each hypothesis tested, a new set of parameters was estimated using MODFLOW2000 , and the resulting new simulated hydraulic heads and ground-water discharges were compared to observed values. Only those conceptual model changes contributing to a significant improvement in model fit, as indicated by a reduction in the sum of squared errors, were retained in the final optimized model.

The final calibrated model was evaluated to assess the likely accuracy of simulated results by comparing measured and expected quantities with simulated values. Good fit to observed hydraulic heads (residuals with absolute values less than $10 \mathrm{~m}$ ) generally occurs in areas of flat hydraulic gradients; moderate fit to observed heads (residuals with absolute values of 10 to $20 \mathrm{~m}$ ) occurs in the remainder of the flat hydraulic gradient areas. Poorer fit to observed heads (residuals with absolute values of greater than $20 \mathrm{~m}$ ) appears to occur in large hydraulic gradient areas. Poorest fit to observed hydraulic heads occurs in the vicinity of Indian Springs, western Yucca Flat, and the southern Bullfrog Hills. Most of these inaccuracies can be attributed to (1) insufficient representation of the hydrogeology in the HFM, (2) misinterpretation of water levels, and (3) model error associated with grid cell size.

Ground-water discharge residuals are fairly random, with as many areas where simulated flows are less than observed flows as areas where simulated flows are greater. The largest unweighted groundwater discharge residuals were at Ash Meadows (central area), Sarcobatus Flat (northeastern area), Death Valley (Badwater and Cottonball Basins, Furnace Creek fan, and western alluvial fans), Penoyer Valley, and Pahrump Valley (near Manse Spring). The two major discharge areas that would contribute the largest volumetric error to the model are Ash Meadows and Death Valley. Ash Meadows (central area) is also one of the largest discharging sites in the DVRFS flow model; therefore, moderate percentages of error in the simulated discharge could result in comparatively large volumetric errors. While Death Valley is of concern, the ground-water discharge observations used in the DVRFS model are prelimi- nary and should not be considered authoritative values of discharge from the Death Valley saltpan.

Estimated parameters were evaluated to determine if reasonable values were estimated by the regression. All estimated parameter values are within the range of expected values. Overall evaluation of the model indicates that although the model is clearly an improvement on previous representations of the flow system, there is an indication of important uncertainties and model error.

Despite the model error and described inadequacies, the current DVRFS model contains the most upto-date representation of hydrogeologic data for the Death Valley region. The inherent limitations result from uncertainty in three basic aspects of the model, including inadequacies in (1) the flow-model observation quality, interpretation, and representation; (2) the interpretation and representation of the complex geometry and spatial variability of hydrogeologic materials and structures in the hydrogeologic framework and ground-water flow model, and (3) the detail of representation of the physical framework and the hydrologic conditions in the flow model. These limitations are discussed and means for improvement are offered.

\section{REFERENCES CITED}

Anderman, Evan, and Hill, M.C., 2000, MODFLOW-2000, The U.S. Geological Survey modular ground-water flow model-Documentation of the hydrogeologicunit flow (HUF) package: U.S. Geological Survey Open-File Report 00-342, 89 p.

Ball, S.H., 1907, A geologic reconnaissance in southwestern Nevada and eastern California: U.S. Geological Survey Bulletin 308, 218 p., 3 plates.

Bard, Jonathon, 1974, Nonlinear parameter estimation: New York, Academic Elsevier, 476 p.

Beatley, J.C., 1976, Vascular plants of the Nevada Test Site and central-southern Nevada-Ecologic and geographic distributions: Technical Information Center, Office of Technical Information, Energy Research and Development Administration, Springfield, Virginia, $308 \mathrm{p}$.

Bedinger, M.S., Langer, W.H., and Reed, J.E., 1989, Ground-water hydrology, in Bedinger, M.S., Sargent, K.A., and Langer, W.H., eds., Studies of geology and hydrology in the Basin and Range Province, southwestern United States, for isolation of high-level radioactive waste-Characterization of the Death Valley region, Nevada and California: U.S. Geological Survey Professional Paper 1370-F, p. 28-35. 
Belcher, Wayne R., Elliott, Peggy E., and Geldon, A.L., 2001, Hydraulic-property estimates for use with a transient ground-water flow model of the Death Valley Regional Ground-Water Flow System, Nevada and California: U.S. Geological Survey Water-Resources Investigations Report 01-4210, 28 p.

Belcher, Wayne R., Faunt, Claudia C., and D'Agnese, Frank A., 2002, Three-dimensional hydrogeologic framework model for use with a steady-state numerical ground-water flow model of the Death Valley regional flow system, Nevada and California: U.S. Geological Survey Water-Resources Investigations Report 01-4254, 87 p.

Benson, Lyman, and Darrow, R.A., 1981, Trees and shrubs of the southwestern deserts: Tucson, University of Arizona Press, $416 \mathrm{p}$.

Blankennagel, R.K., and Weir, J.E. Jr., 1973, Geohydrology of the eastern part of Pahute Mesa, Nevada Test Site, Nye County, Nevada: U.S. Geological Survey Professional Paper 712-B, $35 \mathrm{p}$.

Bonner, L.J., Elliott, P.E., Etchemendy, L.P., and Swartwood, J.R., 1998, Water resources data, Nevada, water year 1997: U.S. Geological Survey Water-Data Report NV-97-1, 636 p.

Bostic, R., Hitch, D., Van Gordon, L., and Swanson, R., 1991, Water resources data, Nevada, water year 1990: U.S. Geological Survey Water-Data Report NV-90-1, $358 \mathrm{p}$.

Burchfiel, B.C., and Davis, G.A., 1981, Mojave desert and environs, in Ernst, W.G., ed., The geotectonic development of California, Rubey v. 1: Englewood Cliffs, New Jersey, Prentice-Hall, p. 217-252.

Byers, F.M. Jr., Carr, W.J., Orkild, P.P., Quinlivan, W.D., and Sargent, K.A., 1976, Volcanic suites and related cauldrons of the Timber Mountain-Oasis Valley caldera complex, southern Nevada: U.S. Geological Survey Professional Paper 919, 70 p.

Caine, J.S., and Forster, C.B., 1999, Fault zone architecture and fluid flow-Insights from field data and numerical modeling, in Haneberg, W.C., Mozley, P.S., Moore, J.C., and Goodwin, L.B., eds., 1999, Faults and subsurface fluid flow in the shallow crust: American Geophysical Union Geophysical Monograph, v. 113, p. 101-127.

Cardinalli, J.L., Roach, L.M., Rush, F.E., and Vasey, B.J., comps., 1968, State of Nevada hydrographic areas: Nevada Division of Water Resources map, 1:500,000 scale.

Carpenter, Everett, 1915, Groundwater in southeastern Nevada: U.S. Geological Survey Water-Supply Paper 365,86 p., 5 plates.
Carr, W.J., 1984, Regional structural setting of Yucca Mountain, southwestern Nevada, and late Cenozoic rates of tectonic activity in part of the southwestern Great Basin, Nevada and California: U.S. Geological Survey Open-File Report 84-854, 109 p.

Carr, W.J., 1990, Styles of extension in the Nevada Test Site region, southern Walker Lane Belt-An integration of volcano-tectonic and detachment fault models, in Wernicke, B.P., ed., Basin and Range extensional tectonics near the latitude of Las Vegas, Nevada: Boulder, Colo., Geological Society of America, Memoir 176, chap. 13, p. 283-303.

Christensen, S., and Cooley, R.L., 1996, Simultaneous confidence intervals for a steady-state leaky aquifer groundwater flow model: Kovar, Karel, and van der Heidje, Paul, eds., Proceedings of the Model CARE Conference, Golden, Colo., September 1996, p. 561-569.

Clary, S.L., McClary, D.R., Whitney, R., and Reeves, D.D., 1995, Water resources data, Nevada, water year 1994: U.S. Geological Survey Water-Data Report NV-94-1, 768 p.

Cooley, R.L., and Naff, R.L., 1990, Regression modeling of ground-water flow: U.S. Geological Survey Techniques of Water-Resources Investigations, book 3, chap. B4, $232 \mathrm{p}$.

Czarnecki, J.B., 1990, Geohydrology and evapotranspiration at Franklin Lake playa, Inyo County, California: U.S. Geological Survey Open-File Report 90-356, $96 \mathrm{p}$.

Czarnecki, J.B., 1997, Geohydrology and evapotranspiration at Franklin Lake playa, Inyo County, California, with a section on estimating evapotranspiration using the energy-budget eddy-correlation technique by Stannard, D.I.: U.S. Geological Survey Water-Supply Paper 2377, 75 p.

Czarnecki, J.B., and Waddell, R.K., 1984, Finite-element simulation of ground-water flow in the vicinity of Yucca Mountain, Nevada-California: U.S. Geological Survey Water-Resources Investigations Report 844349, $38 \mathrm{p}$.

Czarnecki, J.B., and Wilson, W.E., 1991, Conceptual models of the regional ground-water flow and planned studies at Yucca Mountain, Nevada: Hydrological Science and Technology, v. 7, no. 1-4, p. 15-25.

D'Agnese, F.A., Faunt, C.C., Turner, A.K., and Hill, M.C., 1997, Hydrogeologic evaluation and numerical simulation of the Death Valley regional ground-water flow system, Nevada and California: U.S. Geological Survey Water-Resources Investigations Report 964300, $124 \mathrm{p}$. 
D'Agnese, F.A., Faunt, C.C., and Turner, A.K., 1998, An estimated potentiometric surface of the Death Valley region, Nevada and California, using geographic information systems and automated techniques: U.S. Geological Survey Water-Resources Investigations Report 97-4052, 15 p., 1 plate.

DeMeo, G.A., Laczniak, R.J., and Nylund, W.E., 1999, Estimating evapotranspiration rates in Death Valley California [abs], in Slate, J.L. ed., Proceedings of conference on status of geologic research and mapping in Death Valley National Park, Las Vegas, Nevada, April 9-11, 1999: U.S. Geological Survey Open-File Report 99-153, 68 p.

Dettinger, M.D., 1989, Distribution of carbonate-rock aquifers in southern Nevada and the potential for their development, Summary of Findings, 1985-88Program for the study and testing of carbonate-rock aquifers in eastern and southern Nevada, Summary Report No. 1: State of Nevada, Carson City, 37 p.

Dickinson, W.R., and Snyder, W.S., 1979, Geometry of triple junctions related to the San Andreas transform: Journal of Geophysical Research, v. 84, p. 561-572.

Eakin, T.E., 1962, Ground-water appraisal of Ralston and Stonecabin Valleys, Nye County, Nevada: Carson City, Nevada Department of Conservation and Water Resources, Division of Water Resources, GroundWater Resources-Reconnaissance Series Report 12, $38 \mathrm{p}$.

Eakin, T.E., Price, Don, and Harrill, J.R., 1976, Summary appraisals of the Nation's ground-water resourcesGreat Basin region: U.S. Geological Survey Professional Paper 813-G, 37 p.

Emett, D.C., Hutchinson, D.D., Jonson, N.A., and O'Hair, K.L., 1994, Water resources data, Nevada, water year 1993: U.S. Geological Survey Water-Data Report NV93-1, $596 \mathrm{p}$.

Faunt, C.C., 1994, Characterization of the three-dimensional hydrogeologic framework of the Death Valley region, Nevada and California: Golden, Colorado School of Mines, Ph.D. dissertation, 235 p.

Faunt, C.C., 1997, Effect of faulting on ground-water movement in the Death Valley region, Nevada and California: U.S. Geological Survey Water-Resources Investigations Report 95-4132, 42 p., 1 pl.

Fenneman, N.M., 1931, Physiography of western United States: New York, McGraw-Hill Book Company, Inc., $534 \mathrm{p}$.

Franke, O.L., Reilly, T.E., and Bennett, G.D., 1987, Definition of boundary and initial conditions in the analysis of saturated ground-water flow systems-An introduction: U.S. Geological Survey Techniques of WaterResources Investigations, book 3, chap. B5, 15 p.
French, R.H., 1983, A preliminary analysis of precipitation in southern Nevada: Water Resources Center, Desert Research Institute, DOE/NV/10162-10, 42 p.

Garcia, K.T., Gortsema, G.C., Pennington, R.N., and Preissler, A.M., 1992, Water resources data, Nevada, water year 1991: U.S. Geological Survey Water-Data Report NV-91-1, 481 p.

Glancy, P.A., 1968, Water-resources appraisal of MesquiteIvanpah Valley area, Nevada and California: Nevada Department of Conservation and Natural Resources, Water Resources-Reconnaissance Series Report 46, 57 p.

Grose, T.L., 1983, Thirty-two geologic cross-sections, Clark, Esmeralda, Lincoln, Mineral and Nye Counties, Nevada and adjacent areas in California: Nevada Bureau of Mines and Geology Open-File Report 83-13.

Grose, T.L., and Smith, G.I., 1989, Geology, in Bedinger, M.S., Sargent, K.A., and Langer, W.H., eds., Studies of geology and hydrology in the Basin and Range Province, southwestern United States, for isolation of highlevel radioactive waste: U.S. Geological Survey Professional Paper 1370-F, p. 5-19.

Hale, G.S., and Westenburg, C.L., 1995, Selected groundwater data for Yucca Mountain region, southern Nevada and eastern California, calendar year 1993: U.S. Geological Survey Open-File Report 95-158, $67 \mathrm{p}$.

Hales, J.R., Jr., 1972, Surges of maritime tropical air northward over the Gulf of California: Monthly Weather Review, v. 100, p. 298-306.

Hales, J.R., Jr., 1974, Southwestern United States summer monsoon source-Gulf of Mexico or Pacific Ocean?: Journal of Applied Meteorology, v. 13, p. 331-342.

Harbaugh, J.W., Banta, E.R., Hill, M.C., and McDonald, M.G., 2000, MODFLOW-2000, The U.S. Geological Survey's modular ground-water flow model-User guide to modularization concepts and the ground-water flow process: U.S. Geological Survey Open-File Report 00-92, $121 \mathrm{p}$.

Harrill, J.R., 1986, Ground-water storage depletion in Pahrump Valley, Nevada-California, 1962-1975: U.S. Geological Survey Water-Supply Paper 2279, 53 p.

Harrill, J.R., Gates, J.S., and Thomas, J.M., 1988, Major ground-water flow systems in the Great Basin region of Nevada, Utah, and adjacent States: U.S. Geological Survey Hydrologic Investigations Atlas HA-694-C, scale 1:1,000,000.

Harrill, J.R., and Prudic, D.E., 1998, Aquifer systems in the Great Basin region of Nevada, Utah, and adjacent States: U.S. Geological Survey Professional Paper 1409-A, 66 p.

Helsel, D.R., and Hirsch, R.M., 1992, Statistical methods in water resources: Elsevier, Amsterdam, 529 p. 
Hess, D.L., Mello, K.A., Sexton, R.J., and Young, R.L., 1993, Water resources data, Nevada, water year 1992: U.S. Geological Survey Water-Data Report NV-92-1, $511 \mathrm{p}$.

Hevesi, Joseph A., Flint, Alan L., and Flint, Lorraine E., 2002, Preliminary estimates of spatially distributed net infiltration and recharge for the Death Valley region, Nevada-California: U.S. Geological Survey WaterResources Investigations Report 02-4010, 36 p.

Hill, M.C., 1992, A computer program (MODFLOWP) for estimating parameters of a transient three-dimensional, ground-water flow model using nonlinear regression: U.S. Geological Survey Open-File Report 91-484, $358 \mathrm{p}$.

Hill, M.C., 1998, Methods and guidelines for effective model calibration: U.S. Geological Survey WaterResources Investigations Report 98-4005, 90 p.

Hill, M.C., Banta, E.R., Harbaugh, A.W., and Anderman, E.R., 2000, MODFLOW-2000, The U.S. Geological Survey's modular ground-water flow model-User guide to the observation, sensitivity, and parameterestimation procedures and three post-processing programs: U.S. Geological Survey Open-File Report 00-184, 209 p.

Hill, M.C., Cooley, R.L., and Pollock, D.W., 1998, A controlled experiment in ground-water flow model calibration: Ground Water, v. 36, no. 3, p. 520-535.

Hsieh, P.A., and Freckleton, J.R., 1993, Documentation of a computer program to simulate horizontal-flow barriers using the U.S. Geological Survey modular threedimensional finite difference ground-water flow model: U.S. Geological Survey Open-File Report 92477, $32 \mathrm{p}$.

Hunt, C.B., Robinson, T.W., Bowles, W.A., and Washburn, A.L., 1966, Hydrologic basin, Death Valley, California: U.S. Geological Survey Professional Paper 494-B, $138 \mathrm{p}$.

Kilroy, K.C., 1991, Ground-water conditions in Amargosa Desert, Nevada-California, 1952-87: U.S. Geological Survey Water-Resources Investigations Report 894101, $91 \mathrm{p}$.

LaCamera, R.J., and Locke, G.L., 1997, Selected groundwater data for Yucca Mountain region, southern Nevada and eastern California, through December 1996: U.S. Geological Survey Open-File Report 97-821, 79 p.

LaCamera, R.J., and Westenburg, C.L., 1994, Selected ground-water data for Yucca Mountain region, southern Nevada and eastern California, through December 1992: U.S. Geological Survey Open-File Report 94-54, $161 \mathrm{p}$.

LaCamera, R.J., Westenburg, C.L., and Locke, G.L, 1996, Selected ground-water data for Yucca Mountain region, southern Nevada and eastern California, through December 1995: U.S. Geological Survey Open-File Report 96-553, 75 p.

Laczniak, R.J., Cole, J.C., Sawyer, D.A., and Trudeau, D.A., 1996, Summary of hydrogeologic controls on ground-water flow at the Nevada Test Site, Nye County, Nevada: U.S. Geological Survey WaterResources Investigations Report 96-4109, 59 p.

Laczniak, R.J., DeMeo, G.A., Reiner, S.R., Smith, J.L., and Nylund, W.E., 1999, Estimates of ground-water discharge as determined from measurements of evapotranspiration, Ash Meadows area, Nye County, Nevada: U.S. Geological Survey Water-Resources Investigations Report 99-4079, 70 p.

Laczniak, R.J., Smith, J.L., Elliott, P.E., DeMeo, G.A., Chatigny, M.A., and Roemer, G.J., 2001, Groundwater discharge determined from estimates of evapotranspiration, Death Valley regional flow system, Nevada and California: U.S. Geological Survey WaterResources Investigations Report 01-4195, 51 p.

Locke, Augustus, Billingsley, P.R., and Mayo, E.B., 1940, Sierra Nevada tectonic patterns: Geological Society of America Bulletin, v. 51, p. 513-540.

Longwell, C.R., 1960, Possible explanation of diverse structural patterns in southern Nevada: American Journal of Science, v. 258-A, p. 192-203.

Luckey, R.R., Tucci, Patrick, Faunt, C.C., Ervin, E.M., Steinkampf, W.C., D'Agnese, F.A., and Patterson, G.L., 1996, Status of understanding of the saturatedzone ground-water flow system at Yucca Mountain, Nevada as of 1995: U.S. Geological Survey WaterResources Investigations Report 96-4077, 71 p.

Malmberg, G.T., 1965, Available water supply of the Las Vegas ground-water basin, Nevada: U.S. Geological Survey Water-Supply Paper 1780, 116 p.

Malmberg, G.T., 1967, Hydrology of the valley-fill and carbonate-rock reservoirs, Pahrump Valley, NevadaCalifornia: U.S. Geological Survey Water-Supply Paper 1832, 47 p.

Malmberg, G.T., and Eakin, T.E., 1962, Ground-water appraisal of Sarcobatus Flat and Oasis Valley, Nye and Esmeralda Counties, Nevada: Nevada Department of Conservation and Natural Resources, Ground-Water Resources-Reconnaissance Series Report 10, 39 p.

Maxey, G.B., and Eakin, T.E., 1950, Ground water in White River Valley, White Pine, Nye, and Lincoln Counties, Nevada: Nevada State Engineer Water Resources Bulletin No. 8, 59 p.

Maxey, G.B., and Jameson, C.H., 1948, Geology and water resources of Las Vegas, Pahrump, and Indian Springs Valleys, Clark and Nye Counties, Nevada: Nevada State Engineer Water Resources Bulletin No. 5, p. 43, 121. 
McDonald, M.G., and Harbaugh, A.W., 1988, A modular three-dimensional finite-difference ground-water flow model: U.S. Geological Survey Techniques of WaterResources Investigations, book 6, chap. A1, 576 p.

Mendenhall, W.C., 1909, Some desert watering places in southeastern California and southern Nevada: U.S. Geological Survey Water-Supply Paper 224, 98 p.

Mifflin, M.D., 1988, Region 5, Great Basin, in Back, William, Rosenshein, J.S., and Seaber, P.R., eds., Hydrogeology: Boulder, Colorado, Geological Society of America, The geology of North America, v. O-2, p. 69-78.

Miller, G.A., 1977, Appraisal of the water resources of Death Valley, California-Nevada: U.S. Geological Survey Open-File Report 77-728, 68 p.

Peterman, Z.E., and Stuckless, J.S., 1992a, Applications of strontium and other radiogenic tracer isotopes to paleohydrologic studies: Paleohydrogeological Methods and Their Applications, Proceedings of an Nuclear Energy Agency Workshop, Paris, France, November 9-10, 1992, p. 59-84.

Peterman, Z.E., and Stuckless, J.S., 1992b, Strontium isotope characterization of flow systems in southern Nevada, USA: Mineralogical Magazine, v. 58A, p. 711-712.

Peterson, F.F., 1981, Landforms of the Basin and Range province defined for soil survey: Nevada Agricultural Bulletin No. 28, Max C. Fleischmann College of Agriculture, University of Nevada, Reno, Nev., 53 p.

Pistrang, M.A., and Kunkel, Fred, 1964, A brief geologic and hydrologic reconnaissance of the Furnace Creek Wash area, Death Valley National Monument, California: U.S. Geological Survey Water-Supply Paper 1779-Y, 35 p.

Prudic, D.E., Harrill, J.R., and Burbey, T.J., 1993, Conceptual evaluation of regional ground-water flow in the carbonate-rock province of the Great Basin, Nevada, Utah, and adjacent States: U.S. Geological Survey Open-File Report 90-560, 103 p.

Pupacko, A., LaCamera, R.J., Riek, M.M., and Wood, D.B.,1988, Water resources data, Nevada, water year 1986: U.S. Geological Survey Water-Data Report NV-86-1, $263 \mathrm{p}$.

Pupacko, A., LaCamera, R.J., Riek, M.M., and Swartwood, J.R., 1989a, Water resources data, Nevada, water year 1987: U.S. Geological Survey Water-Data Report NV-87-1, $250 \mathrm{p}$.

Pupacko, A., LaCamera, R.J., Riek, M.M., and Swartwood, J.R., 1989b, Water resources data, Nevada, water year 1988: U.S. Geological Survey Water-Data Report NV-88-1, $265 \mathrm{p}$.

Pupacko, A., Van Gordon, L.C., Swartwood, J.R., and Collins, R.P., 1990, Water resources data, Nevada, water year 1989: U.S. Geological Survey Water-Data Report NV-89-1, 332 p.

Quiring, R.F., 1965, Annual precipitation amount as a function of elevation in Nevada south of 38-1/2 latitude, Las Vegas, Nevada: U.S. Weather Bureau Research Statistics, $14 \mathrm{p}$.

Rantz, S.E. (compiler), 1982, Measurement and computation of streamflow: U.S. Geological Survey WaterSupply Paper 2175, v. 1, p. 181-183.

Rice, W.A., 1984, Preliminary two-dimensional regional hydrologic model of the Nevada Test Site and vicinity: Albuquerque, N.M., Sandia National Laboratories Report SAND83-7466, 89 p.

Rush, F.E., 1968, Water-resources appraisal of Clayton Valley-Stonewall Flat area, Nevada and California: Nevada Department of Conservation and Natural Resources, Water Resources-Reconnaissance Series Report 45, 54 p.

Rush, F.E., 1970, Regional ground-water systems in the Nevada Test Site area, Nye, Lincoln, and Clark Counties, Nevada: Carson City, Nevada Department of Conservation and Water Resources, Division of Water Resources, Water Resources-Reconnaissance Series Report 54, 25 p.

Sawyer, D.A., Fleck, R.J., Lanphere, M.A., Warren, R.G., Broxton, D.E., and Hudson, M.R., 1994, Episodic caldera volcanism in the Miocene southwestern Nevada volcanic field-Revised stratigraphic framework, ${ }^{40} \mathrm{Ar} /{ }^{39} \mathrm{Ar}$ geochronology, and implications for magmatism and extension: Geological Society of America Bulletin, v. 106, p. 1304-1318.

Sinton, P.O., 1987, Three-dimensional, steady-state, finitedifference model of the ground-water flow system in the Death Valley ground-water basin, Nevada-California: Golden, Colorado School of Mines, Master's thesis, $145 \mathrm{p}$.

Stewart, J.H., 1971, Basin and range structure-A system of horsts and grabens produced by steep-sided extension: Geological Society of America Bulletin, v. 82, p. 1019-1044.

Stewart, J.H., 1978, Basin and range structure in North America: a review, in Smith R.B., and Eaton, G.P., eds., Cenozoic tectonics and regional geophysics in the western Cordillera: Geological Society of America Memoir 152, p. 1-31.

Stewart, J.H., 1980, Geology of Nevada: Nevada Bureau of Mines and Geology Special Publication 4, 136 p.

Stewart, J.H., 1988, Tectonics of the Walker Lane belt, western Great Basin Mesozoic and Cenozoic deformation in a zone of shear, in Ernst, W.G., ed., Metamorphism and crustal evolution of the Western United States (Ruby Volume 7): Englewood Cliffs, N. J., Prentice-Hall, p. 683-713. 
U.S. Department of Energy, 1997, Regional groundwater flow and tritium transport modeling and risk assessment of the Underground Test Area, Nevada Test Site, Nevada: U.S. Department of Energy Report DOE/NV-477 (Underground Test Area subproject, Phase I data analysis task, v. 1, Regional geologic model data documentation package, ITLV/10972-181), various pagination.

Waddell, R.K., 1982, Two-dimensional, steady-state model of ground-water flow, Nevada Test Site and vicinity, Nevada-California: U.S. Geological Survey WaterResources Investigations Report 82-4085, 72 p.

Waddell, R.K., Robison, J.H., and Blankennagel, R.K., 1984, Hydrology of Yucca Mountain and vicinity, Nevada-California-Investigative results through mid1983: U.S. Geological Survey Water-Resources Investigations Report 84-4267, 72 p.

Walker, G.E., and Eakin, T.E., 1963, Geology and ground water of Amargosa Desert, Nevada-California: Carson City, Nevada Department of Conservation and Natural Resources, Ground-Water Resources-Reconnaissance Series Report 14, 45 p.

Waring, G.A., 1915, Springs of California: U.S. Geological Survey Water-Supply Paper 338, 410 p.
Waring, G.A., revised by Blankenship, R.R., and Bentall, Ray, 1965, Thermal springs of the United States and other countries of the world-A summary: U.S. Geological Survey Professional Paper 492, 383 p.

Wernicke, B.P., Axen, G.J., and Snow, J.K., 1988, Basin and Range extensional tectonics at the latitude of Las Vegas, Nevada: Geological Society of America Bulletin, v. 100, p. 1738-1757.

West, N.E., 1989, Intermountain desert, shrub steppes, woodlands, in Barbour, M.G., and Billings, W.D., eds., North American terrestrial vegetation: Cambridge, United Kingdom, Cambridge University Press, 434 p.

Westenburg, C.L. and LaCamera, R.J., 1996, Selected ground-water data for Yucca Mountain region, southern Nevada and eastern California, through December 1994: U.S. Geological Survey Open-File Report 96-205, 73 p.

Winograd, I.J., and Pearson, F.J., Jr., 1976, Major carbon-14 anomaly in a regional carbonate aquifer-Possible evidence for megascale channeling, south-central Great Basin: Water Resources Research, v. 12, no. 6, p. 1125-1143.

Winograd, I.J., and Thordarson, William, 1975, Hydrologic and hydrochemical framework, south-central Great Basin, Nevada-California, with special reference to the Nevada Test Site: U.S. Geological Survey Professional Paper 712C, p. C1-C126. 